FWS/OBS-79/31

DECEMBER 1979

\title{
Classification of Wetlands and Deepwater Habitats of the United States
}
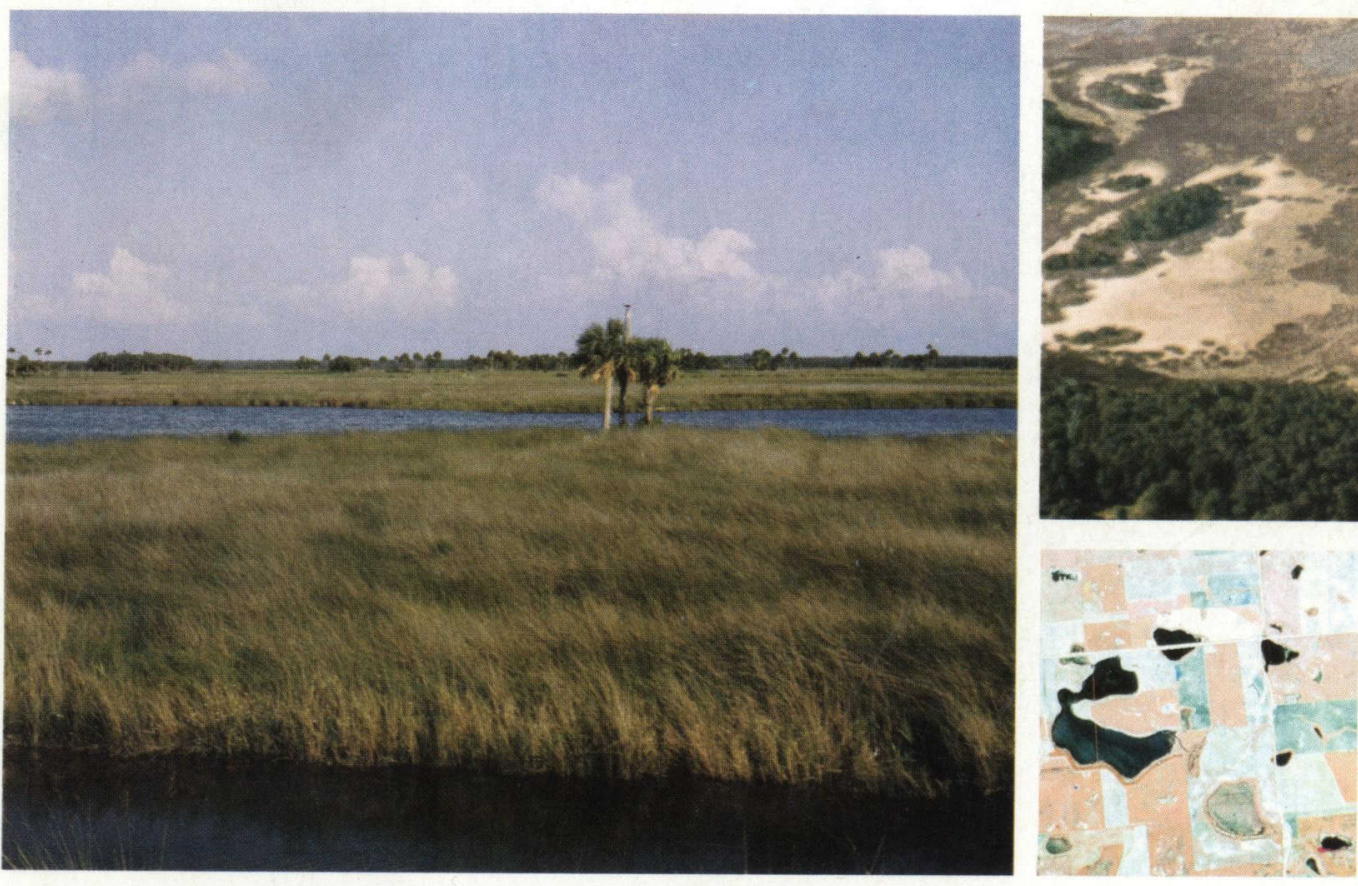

Fish and Wildlife Service U.S. Department of the Interior 
The Biological Services Program was established within the U.S. Fish and Wildlife Service to supply scientific information and methodologies on key environmental issues which have an impact on fish and wildlife resources and their supporting ecosystems. The mission of the Program is as follows:

1. To strengthen the Fish and Wildlife Service in its role as a primary source of information on natural fish and wildlife resources, particularly with respect to environmental impact assessment.

2. To gather, analyze, and present information that will aid decisionmakers in the identification and resolution of problems associated with major land and water use changes.

3. To provide better ecological information and evaluation for Department of the Interior development programs, such as those relating to energy development.

Information developed by the Biological Services Program is intended for use in the planning and decisionmaking process, to prevent or minimize the impact of development on fish and wildlife. Biological Services research activities and technical assistance services are based on an analysis of the issues, the decisionmakers involved and their information needs, and an evaluation of the state-ofthe-art to identify information gaps and determine priorities. This is a strategy to assure that the products produced and disseminated will be timely and useful.

Biological Services projects have been initiated in the following areas:

Coal extraction and conversion

Power plants

Geothermal, mineral, and oil shale development

Water resource analysis, including stream alterations and western water allocation

Coastal ecosystems and Outer Continental Shelf development

Systems and inventory, including National Wetlands Inventory, habitat classification and analysis, and information transfer

The Program consists of the Office of Biological Services in Washington, D.C., which is responsible for overall planning and management; National Teams which provide the Program's central, scientific, and technical expertise, and which arrange for contracting of Biological Services studies with States, universities, consulting firms, and others; Regional staff who provide a link to problems at the operating level; and staff at certain Fish and Wildlife Service research facilities who conduct inhouse research studies. 


\section{CLASSIFICATION OF WETLANDS AND DEEPWATER HABITATS OF THE UNITED STATES}

\section{By}

Lewis M. Cowardin

U.S. Fish and Wildlife Service Northern Prairie Wildlife Research Center

Jamestown, North Dakota 58401

Virginia Carter

U.S. Geological Survey

Reston, Virginia 22092

Francis C. Golet

Department of Natural Resources Science

University of Rhode Island

Kingston, Rhode Island 02881

and

Edward T. LaRoe

U.S. National Oceanographic and Atmospheric Administration Office of Coastal Zone Management

Washington, D.C. 20235

Performed for

Office of Biological Services

Fish and Wildlife Service

U.S. Department of the Interior

Washington, D.C. 20240 


\section{Library of Congress Cataloging in Publication Data}

United States, Fish and Wildlife Service

Classification of wetlands and deepwater habitats of the United States.

(Biological services program ; FWS/OBS-79/31)

1. Wetlands-United States-Classification. 2. Wetland ecology-United States. 3. Aquatic ecology-United States. I. Cowardin, Lewis M. II. Title. III. Series: United States. Fish and Wildlife Service. Biological services program ; FWS/OBS-79/31.

QH76.U54a 79/31 [QH104] 574.5'0973s [574.5'2632] 79-607795 


\section{Foreward}

Wetlands and deepwater habitats are essential breeding, rearing, and feeding grounds for many species of fish and wildlife. They may also perform important flood protection and pollution control funtions. Increasing National and international recognition of these values has intensified the need for reliable information on the status and extent of wetland resources. To develop comparable information over large areas, a clear definition and classification of wetlands and deepwater habitats is required.

The classification system contained in this report was developed by wetland ecologists, with the assistance of many private individuals and organizations and local, State, and Federal agencies. An operational draft was published in October 1977, and a notice of intent to adopt the system for all pertinent Service activities was published December 12, 1977 (42 FR 62432).

The Fish and Wildlife Service is officially adopting this wetland classification system. Future wetland data bases developed by the Service, including the National Wetlands Inventory, will utilize this system. A one-year transition period will allow for training of Service personnel, amendment of administrative manuals, and further development of the National Wetlands Inventory data base. During this period, Service personnel may continue to use the old wetland classification described in Fish and Wildlife Service Circular 39 for Fish and Wildlife Coordination Act reports, wetland acquisition priority determinations, and other activities in conjunction with the new system, where immediate conversion is not practicable.

Upon completion of the transition period, the Circular 39 system will no longer be officially used by the Fish and Wildlife Service except where applicable laws still reference that system or when the only information available is organized according to that system and cannot be restructured without new field surveys.

Other Federal and State agencies are encouraged to convert to the use of this system. No specific legal authorities require the use of this system-or any other system for that matter. However, it is expected that the benefits of National consistency and a develpping wetland data base utilizing this system will result in acceptance and use by most agencies involved in wetland management. Training can be provided to users by the Service, depending on availability of resources. Congressional committees will be notified of this adoption action and will be encouraged to facilitate general adoption of the new system by amending any laws that reference the Circular 39 system.

This is a new system and users will need to study and learn the terminology. The Service is preparing a document to aid in comparing and translating the new system to the Service's former classification system. In the coming year, the Fish and Wildlife Service, in conjunction with the Soil Conservation Service, also plans to develop initial lists of hydrophytic plants and hydric soils that will support interpretation and use of this system.

We believe that this system will provide a suitable basis for information gathering for most scientific, educational, and administrative purposes; however, it will not fit all needs. For instance, historical or potentially restorable wetlands are not included in this system, nor was the system designed to accommodate all the requirements of the many recently passed wetland statutes. No attempt was made to define the proprietary or jurisdictional boundaries of Federal, State, or local agencies. Nevertheless, the basic design of the classification system and the resulting data base should assist substantially in the administration of these programs.

This report represents the most current methodology available for wetland classification and culminates a longterm effort involving many wetland scientists. Although it may require revision from time to time, it will serve us well in the years ahead. We hope all wetland personnel in all levels of government and the private sector come to know it and use it for the ultimate benefit of America's wetlands.
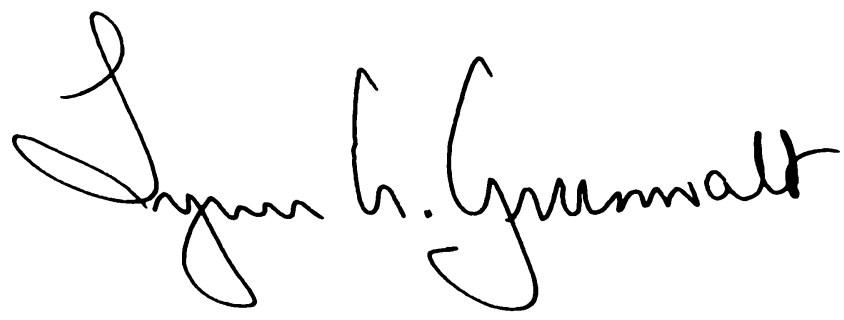

Lynn A. Greenwalt, Director U.S. Fish and Wildlife Service 


\section{Preface}

Since its publication in 1979, Classification of Wetlands and Deepwater Habitats of the United States has been used in the National inventory of wetlands conducted by the U.S. Fish and Wildlife Service. The system has been widely used throughout the United States and is often cited in the scientific literature. There has also been considerable international interest in use of the classification.

Copies from the first printing have been expended and demand requires this reprinting. We have taken this opportunity to correct a number of minor typographical errors, bring plant names into conformity with the National List of Scientific Plant Names (U.S. Dept. Agriculture 1982), and to upgrade the quality of plates as well as furnish additional plates. No changes have been made that either alter the structure of the classification or the meaning of the definitions. Such major revisions must be deferred until certain prerequisite tasks are accomplished.

Completion of the list of hydrophytes and other plants occurring in wetlands and the list of hydric soils (see page 3 ) has been a task of far greater complexity than we envisioned when writing the classification. These lists have received extensive review and are being prepared as computer data bases. In addition, the lists will contain a great deal of ancillary information that will make possible the development of methodologies for their use in both the delineation and classification of wetlands. When the lists and methodologies are completed, reviewed, and tested we will revise the classification and use the lists to add precision to the definitions. At the same time, we will address specific technical problems that have arisen during application of the classification.

The plates at the end of this publication are included primarily to illustrate a variety of examples of wetland classification. We have attempted to include photographs from various regions of the country insofar as possible; however, final selection of plates was based on the availability of both high-quality photographs and the detailed field data required for accurate classification. While on sabbatical leave from the University of Rhode Island in 1985, Dr. Frank Golet took numerous photographs of Alaskan wetlands. Addition of many of these and several photographs from other regions helps somewhat to correct a regional imbalance.

We acknowledge the assistance of Dr. J. Henry Sather who served as editor for the reprinting. He spent many hours compiling minor errors and inconsistencies and preparing final copy for the printer. We thank Mr. Jon Hall, National Wetlands Inventory Coordinator for the Alaska region, for his assistance to Dr. Golet during his stay in Alaska.

Lewis M. Cowardin

Virginia Carter

Francis C. Golet

Edward T. LaRoe

September 24, 1985 


\section{Contents}

Abstract ......................................... 1

Wetlands and Deepwater Habitats ........................... 3

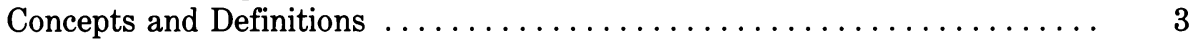

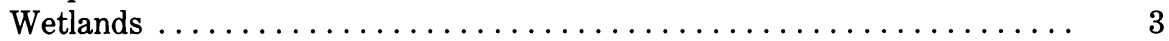

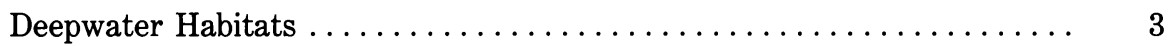

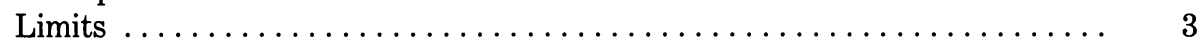

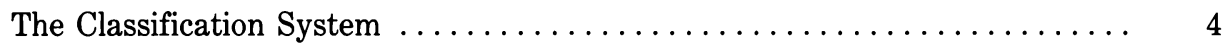

Hierarchical Structure ............................... 4

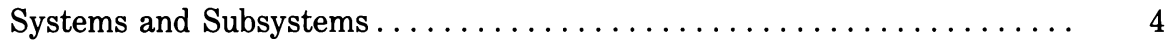

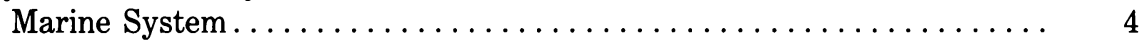

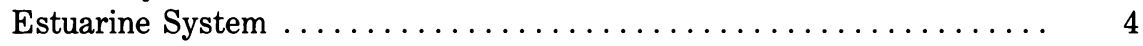

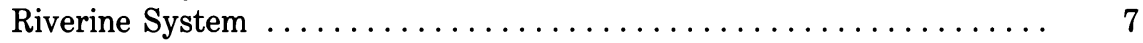

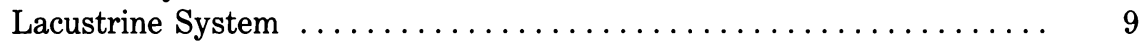

Palustrine System ................................ 10

Classes, Subclasses, and Dominance Types.................. 10

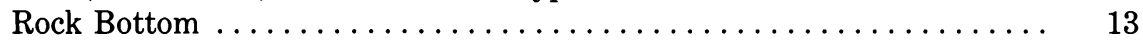

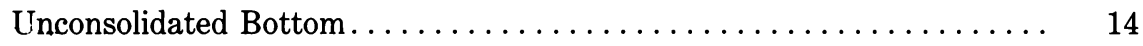

Aquatic Bed ....................................... 15

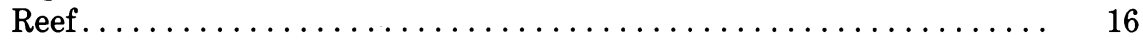

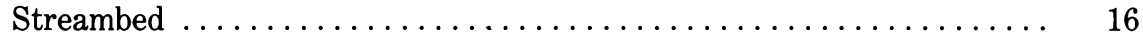

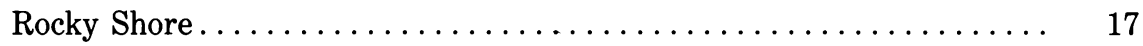

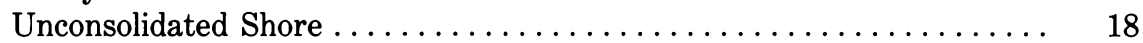

Moss-Lichen Wetland ................................ 19

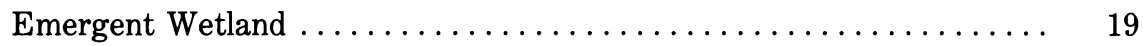

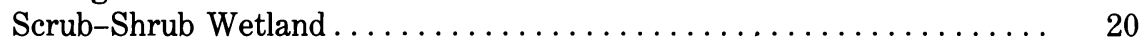

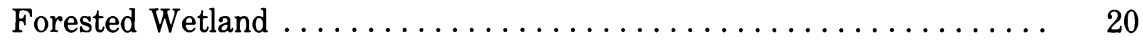

Modifiers ....................................... 21

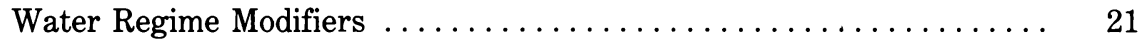

Water Chemistry Modifiers ........................ 22

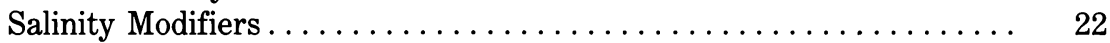

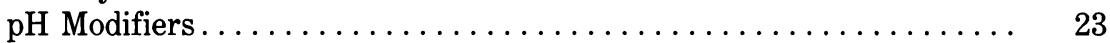

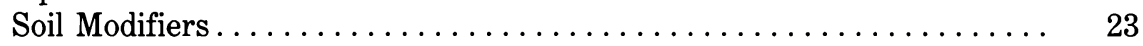

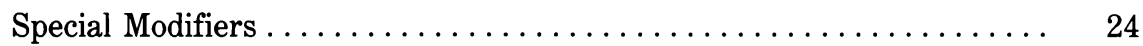

Regionalization for the Classification System .................. 24

Use of the Classification System .......................... 26

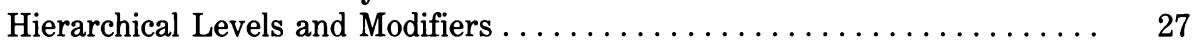

Relationship to Other Wetland Classifications ................. 27

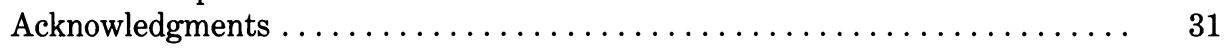

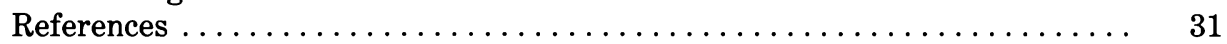

Appendix A. Scientific and common names of plants .............. 35

Appendix B. Scientific and common names of animals . . . . . . . . . . . 38

Appendix C. Glossary of terms .......................... 40

Appendix D. Criteria for distinguishing organic
soils from mineral soils $\ldots \ldots \ldots \ldots \ldots \ldots \ldots \ldots \ldots \ldots$

Appendix E. Artificial key to the Systems $\ldots \ldots \ldots \ldots \ldots \ldots \ldots \ldots \ldots . \ldots \ldots 44$

Artificial key to the Classes $\ldots \ldots \ldots \ldots \ldots \ldots \ldots \ldots \ldots .44$ 
Tables

No.

1 Distribution of Subclasses within the classification hierarchy.

2 Salinity modifiers used in this classification system.

$3 \mathrm{pH}$ modifiers used in this classification system.

4 Comparison of wetland types described in U.S. Fish and Wildlife Service Circular 39 with some of the major components of this classification system.

5 Comparison of the zones of Stewart and Kantrud's (1971) classification with the water regime modifiers used in the present classification system.

Figures

No.

1 Classification hierarchy of wetlands and deepwater habitats, showing Systems, Subsystems, and Classes. The Palustrine System does not include deepwater habitats.

2 Distinguishing features and examples of habitats in the Marine System.

3 Distinguishing features and examples of habitats in the Estuarine System.

4 Distinguishing features and examples of habitats in the Riverine System.

5 Distinguishing features and examples of habitats in the Lacustrine System.

6 Distinguishing features and examples of habitats in the Palustrine System.

7 Ecoregions of the United States after Bailey (1976) with the addition of 10 Marine and Estuarine Provinces proposed in our classification.

8 Comparison of the Water Chemistry Subclasses of Stewart and Kantrud (1972) with Water Chemistry Modifiers used in the present classification system. 


\title{
Classification of Wetlands and Deepwater Habitats of the United States
}

\author{
by \\ Lewis M. Cowardin \\ U.S. Fish and Wildlife Service \\ Northern Prairie Wildlife Research Center \\ Jamestown, North Dakota 58401 \\ Virginia Carter \\ U.S. Geological Survey, Reston, Virginia 22092 \\ Francis C. Golet \\ Department of Natural Resources Science \\ University of Rhode Island, Kingston, Rhode Island 02881 \\ and \\ Edward T. LaRoe \\ U.S. National Oceanographic and Atmospheric Administration \\ Office of Coastal Zone Management \\ Washington, D.C. 20235
}

\begin{abstract}
This classification, to be used in a new inventory of wetlands and deepwater habitats of the United States, is intended to describe ecological taxa, arrange them in a system useful to resource managers, furnish units for mapping, and provide uniformity of concepts and terms. Wetlands are defined by plants (hydrophytes), soils (hydric soils), and frequency of flooding. Ecologically related areas of deep water, traditionally not considered wetlands, are included in the classification as deepwater habitats.

Systems form the highest level of the classification hierarchy; five are defined-Marine, Estuarine, Riverine, Lacustrine, and Palustrine. Marine and Estuarine Systems each have two Subsystems, Subtidal and Intertidal; the Riverine System has four Subsystems, Tidal, Lower Perennial, Upper Perennial, and Intermittent; the Lacustrine has two, Littoral and Limnetic; and the Palustrine has no Subsystems.

Within the Subsystems, Classes are based on substrate material and flooding regime, or on vegetative life form. The same Classes may appear under one or more of the Systems or Subsystems. Six Classes are based on substrate and flooding regime: (1) Rock Bottom with a substrate of bedrock, boulders, or stones; (2) Unconsolidated Bottom with a substrate of cobbles, gravel, sand, mud, or organic material; (3) Rocky Shore with the same substrates as Rock Bottom; (4) Unconsolidated Shore with the same substrates as Unconsolidated Bottom; (5) Streambed with any of the substrates; and (6) Reef with a substrate composed of the living and dead remains of invertebrates (corals, mollusks, or worms). The bottom Classes, (1) and (2) above, are flooded all or most of the time and the shore Classes, (3) and (4), are exposed most of the time. The Class Streambed is restricted to channels of intermittent streams and tidal channels that are dewatered at low tide. The life form of the dominant vegetation defines the five Classes based on vegetative form: (1) Aquatic Bed, dominated by plants that grow principally on or below the surface of the water; (2) Moss-Lichen Wetland, dominated by mosses or lichens; (3) Emergent Wetland, dominated by emergent herbaceous angiosperms; (4) Scrub-Shrub Wetland, dominated by shrubs or small trees; and (5) Forested Wetland, dominated by large trees.

The Dominance Type, which is named for the dominant plant or animal forms, is the lowest level of the classification hierarchy. Only examples are provided for this level; Dominance Types must be developed by individual users of the classification.

Modifying terms applied to the Classes or Subclasses are essential for use of the system. In tidal areas, the type and duration of flooding are described by four Water Regime Modifiers: subtidal, irregularly exposed, regularly flooded, and irregularly flooded. In nontidal areas, eight Regimes are used: permanently flooded, intermittently exposed, semipermanently flooded, seasonally flooded, saturated, temporarily flooded, intermittently flooded, and artificially flooded. A hierarchical system
\end{abstract}


of Water Chemistry Modifiers, adapted from the Venice System, is used to describe the salinity of the water. Fresh waters are further divided on the basis of $\mathrm{pH}$. Use of a hierarchical system of soil modifiers taken directly from U.S. soil taxonomy is also required. Special modifiers are used where appropriate: excavated, impounded, diked, partly drained, farmed, and artificial.

Regional differences important to wetland ecology are described through a regionalization that combines a system developed for inland areas by R. G. Bailey in 1976 with our Marine and Estuarine provinces.

The structure of the classification allows it to be used at any of several hierarchical levels. Special data required for detailed application of the system are frequently unavailable, and thus data gathering may be prerequisite to classification. Development of rules by the user will be required for specific map scales. Dominance Types and relationships of plant and animal communities to environmental characteristics must also be developed by users of the classification. Keys to the Systems and Classes are furnished as a guide, and numerous wetlands and deepwater habitats are illustrated and classified. The classification system is also compared with several other systems currently in use in the United States.

The U.S. Fish and Wildlife Service conducted an inventory of the wetlands of the United States (Shaw and Fredine 1956) in 1954. Since then, wetlands have undergone considerable change, both natural and man related, and their characteristics and natural values have become better defined and more widely known. During this interval, State and Federal legislation has been passed to protect wetlands, and some Statewide wetland surveys have been conducted.

In 1974, the U.S. Fish and Wildlife Service directed its Office of Biological Services to design and conduct a new National inventory of wetlands. Whereas the single purpose of the 1954 inventory was to assess the amount and types of valuable waterfowl habitat, the scope of the new project is considerably broader (Montanari and Townsend 1977). It will provide basic data on the characteristics and extent of the Nation's wetlands and deepwater habitats and should facilitate the management of these areas on a sound, multiple-use basis.

Before the 1954 inventory was begun, Martin et al. (1953) had devised a wetland classification system to serve as a framework for the National inventory. The results of the inventory and an illustrated description of the 20 wetland types were published as U.S. Fish and Wildlife Service Circular 39 (Shaw and Fredine 1956). This circular has been one of the most common and most influential documents used in the continuous battle to preserve a critically valuable but rapidly diminishing National resource (Stegman 1976). However, the shortcomings of this work are well known (e.g., see Leitch 1966; Stewart and Kantrud 1971).

In attempting to simplify their classification, Martin et al. (1953) not only ignored ecologically critical differences, such as the distinction between fresh and mixosaline inland wetlands but also placed dissimilar habitats, such as forests of boreal black spruce (Picea mariana) and of southern cypress-gum (Taxodium distichum-Nyssa aquatica) in the same category, with no provisions in the system for distinguishing between them. Because of the central emphasis on waterfowl habitat, far greater attention was paid to vegetated areas than to nonvegetated areas. Probably the greatest single disadvantage of the Martin et al. system was the inadequate definition of types, which led to inconsistencies in application.

Numerous other classifications of wetlands and deepwater habitats have been developed (Stewart and Kantrud 1971; Golet and Larson 1974; Jeglum et al. 1974; Odum et al. 1974; Zoltai et al. 1975; Millar 1976), but most of these are regional systems and none would fully satisfy National needs. Because of the weaknesses inherent in Circular 39, and because wetland ecology has become significantly better understood since 1954 , the U.S. Fish and Wildlife Service elected to construct a new National classification system as the first step toward a new National inventory. The new classification, presented here, has been designed to meet four long-range objectives: (1) to describe ecological units that have certain homogeneous natural attributes; (2) to arrange these units in a system that will aid decisions about resource management; (3) to furnish units for inventory and mapping; and (4) to provide uniformity in concepts and terminology throughout the United States.

Scientific and common names of plants (Appendix A) and animals (Appendix B) were taken from various sources cited in the text. No attempt has been made to resolve nomenclatorial problems where there is a taxonomic dispute. Many of the terms used in this classification have various meanings even in the scientific literature and in some instances our use of terms is new. We have provided a glossary (Appendix C) to guide the reader in our usage of terms. 


\section{WETLANDS AND DEEPWATER HABITATS}

\section{Concepts and Definitions}

Marshes, swamps, and bogs have been well-known terms for centuries, but only relatively recently have attempts been made to group these landscape units under the single term "wetlands." This general term has grown out of a need to understand and describe the characteristics and values of all types of land, and to wisely and effectively manage wetland ecosystems. There is no single, correct, indisputable, ecologically sound definition for wetlands, primarily because of the diversity of wetlands and because the demarcation between dry and wet environments lies along a continuum. Because reasons or needs for defining wetlands also vary, a great proliferation of definitions has arisen. The primary objective of this classification is to impose boundaries on natural ecosystems for the purposes of inventory, evaluation, and management.

\section{Wetlands}

In general terms, wetlands are lands where saturation with water is the dominant factor determining the nature of soil development and the types of plant and animal communities living in the soil and on its surface. The single feature that most wetlands share is soil or substrate that is at least periodically saturated with or covered by water. The water creates severe physiological problems for all plants and animals except those that are adapted for life in water or in saturated soil.

WETLANDS are lands transitional between terrestrial and aquatic systems where the water table is usually at or near the surface or the land is covered by shallow water. For purposes of this classification wetlands must have one or more of the following three attributes: (1) at least periodically, the land supports predominantly hydrophytes; ${ }^{1}$ (2) the substrate is predominantly undrained hydric soil; ${ }^{2}$ and (3) the substrate is nonsoil and is saturated with water or covered by shallow water at some time during the growing season of each year.

The term wetland includes a variety of areas that fall into one of five categories: (1) areas with hydrophytes and hydric soils, such as those commonly known as marshes, swamps, and bogs; (2) areas without hydrophytes but with hydric soils-for example, flats where drastic fluctuation in water level, wave action, turbidity, or high concentra-

${ }^{1}$ The U.S. Fish and Wildlife Service is preparing a list of hydrophytes and other plants occurring in wetlands of the United States.

2The U.S. Soil Conservation Service is preparing a preliminary list of hydric soils for use in this classification system. tion of salts may prevent the growth of hydrophytes; (3) areas with hydrophytes but nonhydric soils, such as margins of impoundments or excavations where hydrophytes have become established but hydric soils have not yet developed; (4) areas without soils but with hydrophytes such as the seaweed-covered portion of rocky shores; and (5) wetlands without soil and without hydrophytes, such as gravel beaches or rocky shores without vegetation.

Drained hydric soils that are now incapable of supporting hydrophytes because of a change in water regime are not considered wetlands by our definition. These drained hydric soils furnish a valuable record of historic wetlands, as well as an indication of areas that may be suitable for restoration.

Wetlands as defined here include lands that are identified under other categories in some land-use classifications. For example, wetlands and farmlands are not necessarily exclusive. Many areas that we define as wetlands are farmed during dry periods, but if they are not tilled or planted to crops, a practice that destroys the natural vegetation, they will support hydrophytes.

\section{Deepwater Habitats}

DEEPWATER HABITATS are permanently flooded lands lying below the deepwater boundary of wetlands. Deepwater habitats include environments where surface water is permanent and often deep, so that water, rather than air, is the principal medium within which the dominant organisms live, whether or not they are attached to the substrate. As in wetlands, the dominant plants are hydrophytes; however, the substrates are considered nonsoil because the water is too deep to support emergent vegetation (U.S. Soil Conservation Service, Soil Survey Staff 1975).

Wetlands and deepwater habitats are defined separately because traditionally the term wetland has not included deep permanent water; however, both must be considered in an ecological approach to classification. We define five major Systems: Marine, Estuarine, Riverine, Lacustrine, and Palustrine. The first four of these include both wetland and deepwater habitats but the Palustrine includes only wetland habitats.

\section{Limits}

The upland limit of wetland is designated as (1) the boundary between land with predominantly hydrophytic cover and land with predominantly mesophytic or xerophytic cover; (2) the boundary between soil that is predominantly hydric and soil that is predominantly nonhydric; or (3) in the case of wetlands without vegetation or soil, the boundary between land that is flooded or saturated at some time during the growing season each year and land that is not. 
The boundary between wetland and deepwater habitat in the Marine and Estuarine Systems coincides with the elevation of the extreme low water of spring tide; permanently flooded areas are considered deepwater habitats in these Systems. The boundary between wetland and deepwater habitat in the Riverine and Lacustrine Systems lies at a depth of $2 \mathrm{~m}$ ( 6.6 feet) below low water; however, if emergents, shrubs, or trees grow beyond this depth at any time, their deepwater edge is the boundary.

The 2-m lower limit for inland wetlands was selected because it represents the maximum depth to which emergent plants normally grow (Welch 1952; Zhadin and Gerd 1963; Sculthorpe 1967). As Daubenmire (1968:138) stated, emergents are not true aquatic plants, but are "amphibious," growing in both permanently flooded and wet, nonflooded soils. In their wetland classification for Canada, Zoltai et al. (1975) also included only areas with water less than $2 \mathrm{~m}$ deep.

\section{THE CLASSIFICATION SYSTEM}

The structure of this classification is hierarchical, progressing from Systems and Subsystems, at the most general levels, to Classes, Subclasses, and Dominance Types. Figure 1 illustrates the classification structure to the class level. Table 1 lists the Classes and Subclasses for each System and Subsystem. Artificial keys to the Systems and Classes are given in Appendix E. Modifiers for water regime, water chemistry, and soils are applied to Classes, Subclasses, and Dominance Types. Special modifiers describe wetlands and deepwater habitats that have been either created or highly modified by man or beavers.

\section{Hierarchical Structure}

\section{Systems and Subsystems}

The term SYSTEM refers here to a complex of wetlands and deepwater habitats that share the influence of similar hydrologic, geomorphologic, chemical, or biological factors. We further subdivide Systems into more specific categories called SUBSYSTEMS.

The characteristics of the five major Systems-Marine, Estuarine, Riverine, Lacustrine, and Palustrine-have been discussed at length in the scientific literature and the concepts are well recognized; however, there is frequent disagreement as to which attributes should be used to bound the Systems in space. For example, both the limit of tidal influence and the limit of ocean-derived salinity have been proposed for bounding the upstream end of the
Estuarine System (Caspers 1967). As Bormann and Likens (1969) pointed out, boundaries of ecosystems are defined to meet practical needs.

\section{Marine System}

Definition. The Marine System (Fig. 2) consists of the open ocean overlying the continental shelf and its associated high-energy coastline. Marine habitats are exposed to the waves and currents of the open ocean and the water regimes are determined primarily by the ebb and flow of oceanic tides. Salinities exceed $30 \%$, with little or no dilution except outside the mouths of estuaries. Shallow coastal indentations or bays without appreciable freshwater inflow, and coasts with exposed rocky islands that provide the mainland with little or no shelter from wind and waves, are also considered part of the Marine System because they generally support typical marine biota.

Limits. The Marine System extends from the outer edge of the continental shelf shoreward to one of three lines: (1) the landward limit of tidal inundation (extreme high water of spring tides), including the splash zone from breaking waves; (2) the seaward limit of wetland emergents, trees, or shrubs; or (3) the seaward limit of the Estuarine System, where this limit is determined by factors other than vegetation. Deepwater habitats lying beyond the seaward limit of the Marine System are outside the scope of this classification system.

Description. The distribution of plants and animals in the Marine System primarily reflects differences in four factors: (1) degree of exposure of the site to waves; (2) texture and physicochemical nature of the substrate; (3) amplitude of the tides; and (4) latitude, which governs water temperature, the intensity and duration of solar radiation, and the presence or absence of ice.

\section{Subsystems.}

Subtidal.-The substrate is continuously submerged. Intertidal. - The substrate is exposed and flooded by tides; includes the associated splash zone.

Classes. Rock Bottom, Unconsolidated Bottom, Aquatic Bed, Reef, Rocky Shore, and Unconsolidated Shore.

\section{Estuarine System}

Definition. The Estuarine System (Fig. 3) consists of deepwater tidal habitats and adjacent tidal wetlands that are usually semienclosed by land but have open, partly obstructed, or sporadic access to the open ocean, and in which ocean water is at least occasionally diluted by freshwater runoff from the land. The salinity may be periodically increased above that of the open ocean by evaporation. Along some low-energy coastlines there is appreciable dilution of sea water. Offshore areas with typical estuarine plants and animals, such as red mangroves (Rhizophora 


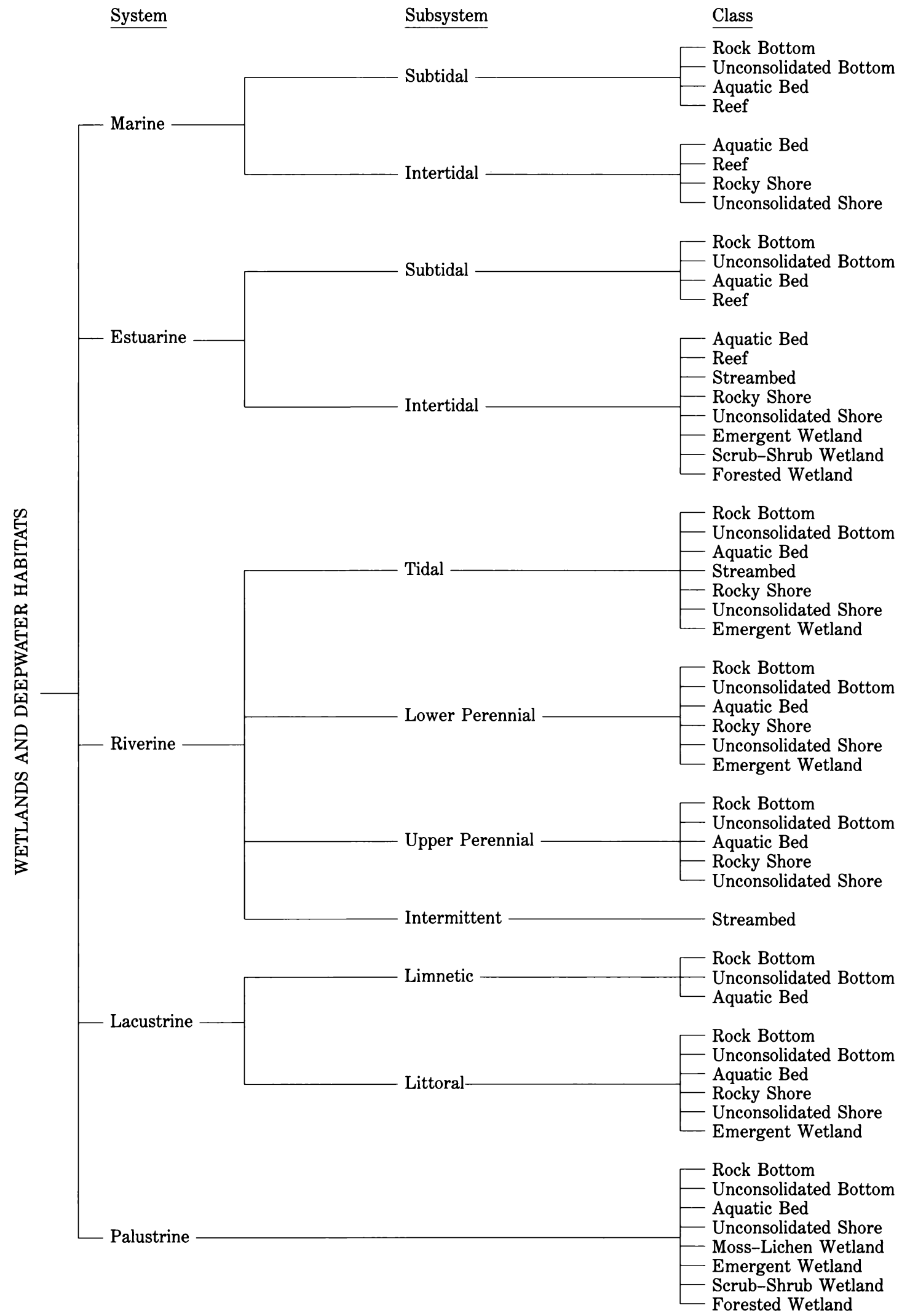

Fig. 1. Classification hierarchy of wetlands and deepwater habitats, showing Systems, Subsystems, and Classes. The Palustrine System does not include deepwater habitats. 
Table 1. Distribution of Subclasses within the classification hierarchy.

\begin{tabular}{|c|c|c|c|c|c|c|c|c|c|c|c|}
\hline \multirow[b]{3}{*}{ Class/Subclass } & \multicolumn{11}{|c|}{ System and Subsystem ${ }^{a}$} \\
\hline & \multicolumn{2}{|c|}{ Marine } & \multicolumn{2}{|c|}{ Estuarine } & \multicolumn{4}{|c|}{ Riverine } & \multicolumn{2}{|c|}{ Lacustrine } & \multirow{2}{*}{$\frac{\text { Palustrine }}{-}$} \\
\hline & $\mathrm{ST}$ & IT & $\mathrm{ST}$ & IT & TI & LP & UP & IN & LM & LT & \\
\hline \multicolumn{12}{|l|}{ Rock Bottom } \\
\hline Bedrock & $\mathrm{X}$ & & $\mathrm{X}$ & & $\mathrm{X}$ & & $\mathrm{X}$ & & $\mathrm{X}$ & $\mathrm{X}$ & $\mathrm{X}$ \\
\hline Rubble & $\mathrm{X}$ & & $\mathrm{X}$ & & $\mathrm{X}$ & & $\mathrm{X}$ & & $\mathrm{X}$ & $\mathrm{X}$ & $\mathrm{X}$ \\
\hline \multicolumn{12}{|l|}{ Unconsolidated Bottom } \\
\hline Cobble-Gravel & $\mathrm{X}$ & & $\mathrm{X}$ & & $\mathrm{X}$ & $\mathrm{X}$ & $\mathrm{X}$ & & $\mathrm{X}$ & $\mathrm{X}$ & $\mathrm{X}$ \\
\hline Sand & $\mathrm{X}$ & & $\mathrm{X}$ & & $\mathrm{X}$ & $\mathrm{X}$ & $\mathrm{X}$ & & $\mathrm{X}$ & $\mathrm{X}$ & $\mathrm{X}$ \\
\hline Mud & $\mathrm{X}$ & & $\mathrm{X}$ & & $\mathrm{X}$ & $\mathrm{X}$ & $\mathrm{X}$ & & $\mathrm{X}$ & $\mathrm{X}$ & $\mathrm{X}$ \\
\hline Organic & & & $\mathrm{X}$ & & $\mathrm{X}$ & $\mathrm{X}$ & & & $\mathrm{X}$ & $\mathrm{X}$ & $\mathrm{X}$ \\
\hline \multicolumn{12}{|l|}{ Aquatic Bed } \\
\hline Algal & $\mathrm{X}$ & $\mathrm{X}$ & $\mathrm{X}$ & $\mathrm{X}$ & $\mathrm{X}$ & $\mathrm{X}$ & $\mathrm{X}$ & & $\mathrm{X}$ & $\mathrm{X}$ & $\mathrm{X}$ \\
\hline Aquatic Moss & & & & & $\mathrm{X}$ & $\mathrm{X}$ & $\mathrm{X}$ & & $\mathrm{X}$ & $\mathrm{X}$ & $\mathrm{X}$ \\
\hline Rooted Vascular & $\mathrm{X}$ & $\mathrm{X}$ & $\mathrm{X}$ & $\mathrm{X}$ & $\mathrm{X}$ & $\mathrm{X}$ & $\mathrm{X}$ & & $\mathrm{X}$ & $\mathrm{X}$ & $\mathrm{X}$ \\
\hline Floating Vascular & & & $\mathrm{X}$ & $\mathrm{X}$ & $\mathrm{X}$ & $\mathrm{X}$ & $\mathrm{X}$ & & $\mathrm{X}$ & $\mathrm{X}$ & $\mathrm{X}$ \\
\hline \multicolumn{12}{|l|}{ Reef } \\
\hline Coral & $\mathrm{X}$ & $\mathrm{X}$ & & & & & & & & & \\
\hline Mollusk & & & $\mathrm{X}$ & $\mathrm{X}$ & & & & & & & \\
\hline Worm & $\mathrm{X}$ & $\mathrm{X}$ & $\mathrm{X}$ & $\mathrm{X}$ & & & & & & & \\
\hline \multicolumn{12}{|l|}{ Streambed } \\
\hline Bedrock & & & & $\mathrm{X}$ & $\mathrm{X}$ & & & $\mathrm{X}$ & & & \\
\hline Rubble & & & & $\mathrm{X}$ & $\mathrm{X}$ & & & $\mathrm{X}$ & & & \\
\hline Cobble-Gravel & & & & $\mathrm{X}$ & $\mathrm{X}$ & & & $\mathrm{X}$ & & & \\
\hline Sand & & & & $\mathrm{X}$ & $\mathrm{X}$ & & & $\mathrm{X}$ & & & \\
\hline Mud & & & & $\mathrm{X}$ & $\mathrm{X}$ & & & $\mathrm{X}$ & & & \\
\hline Organic & & & & $\mathrm{X}$ & $\mathrm{X}$ & & & $\mathrm{X}$ & & & \\
\hline Vegetated & & & & & & & & $\mathrm{x}$ & & & \\
\hline \multicolumn{12}{|l|}{ Rocky Shore } \\
\hline Bedrock & & $\mathrm{X}$ & & $\mathrm{X}$ & $\mathrm{X}$ & $\mathrm{X}$ & $\mathrm{X}$ & & & $\mathrm{X}$ & \\
\hline Rubble & & $\mathrm{X}$ & & $\mathrm{X}$ & $\mathrm{X}$ & $\mathrm{X}$ & $\mathrm{X}$ & & & $\mathrm{X}$ & \\
\hline \multicolumn{12}{|l|}{ Unconsolidated Shore } \\
\hline Cobble-Gravel & & $\mathrm{X}$ & & $\mathrm{X}$ & $\mathrm{X}$ & $\mathrm{X}$ & $\mathrm{X}$ & & & $\mathrm{X}$ & $\mathrm{X}$ \\
\hline Sand & & $\mathrm{X}$ & & $\mathrm{X}$ & $\mathrm{X}$ & $\mathrm{X}$ & $\mathrm{X}$ & & & $\mathrm{X}$ & $\mathrm{X}$ \\
\hline Mud & & $\mathrm{X}$ & & $\mathrm{X}$ & $\mathrm{X}$ & $\mathrm{X}$ & $\mathrm{X}$ & & & $\mathrm{X}$ & $\mathrm{X}$ \\
\hline Organic & & $\mathrm{X}$ & & $\mathrm{X}$ & $\mathrm{X}$ & $\mathrm{X}$ & $\mathrm{X}$ & & & $\mathrm{X}$ & $\mathrm{X}$ \\
\hline Vegetated & & & & & $\mathrm{X}$ & $\mathrm{X}$ & $\mathrm{x}$ & & & $\mathrm{x}$ & $\mathrm{X}$ \\
\hline \multicolumn{12}{|l|}{ Moss-Lichen Wetland } \\
\hline Moss & & & & & & & & & & & $\mathrm{X}$ \\
\hline Lichen & & & & & & & & & & & $\mathrm{X}$ \\
\hline \multicolumn{12}{|l|}{ Emergent Wetland } \\
\hline Persistent & & & & $\mathrm{X}$ & & & & & & & $\mathrm{X}$ \\
\hline Nonpersistent & & & & $\mathrm{X}$ & $\mathrm{X}$ & $\mathrm{X}$ & $\mathrm{X}$ & & & $\mathrm{x}$ & $\mathrm{X}$ \\
\hline \multicolumn{12}{|l|}{ Scrub-Shrub Wetland } \\
\hline Broad-leaved Deciduous & & & & $\mathrm{X}$ & & & & & & & $\mathrm{X}$ \\
\hline Needle-leaved Deciduous & & & & $\mathrm{X}$ & & & & & & & $\mathrm{X}$ \\
\hline Broad-leaved Evergreen & & & & $\mathrm{X}$ & & & & & & & $\mathrm{X}$ \\
\hline Needle-leaved Evergreen & & & & $\mathrm{X}$ & & & & & & & $\mathrm{X}$ \\
\hline Dead & & & & $\mathrm{X}$ & & & & & & & $\mathrm{X}$ \\
\hline
\end{tabular}


Table 1. Continued.

\begin{tabular}{|c|c|c|c|c|c|c|c|c|c|c|c|}
\hline \multirow[b]{3}{*}{ Class/Subclass } & \multicolumn{11}{|c|}{ System and Subsystem ${ }^{\mathrm{a}}$} \\
\hline & \multicolumn{2}{|c|}{ Marine } & \multicolumn{2}{|c|}{ Estuarine } & \multicolumn{4}{|c|}{ Riverine } & \multicolumn{2}{|c|}{ Lacustrine } & \multirow{2}{*}{$\frac{\text { Palustrine }}{-}$} \\
\hline & ST & IT & ST & IT & $\overline{\mathrm{TI}}$ & LP & UP & IN & $\mathrm{LM}$ & $\overline{\mathrm{LT}}$ & \\
\hline \multicolumn{12}{|l|}{ Forested Wetland } \\
\hline Broad-leaved Deciduous & & & & $\mathrm{X}$ & & & & & & & $\mathrm{X}$ \\
\hline Needle-leaved Deciduous & & & & $\mathrm{X}$ & & & & & & & $\mathrm{X}$ \\
\hline Broad-leaved Evergreen & & & & $\mathrm{X}$ & & & & & & & $\mathrm{X}$ \\
\hline Needle-leaved Evergreen & & & & $\mathrm{X}$ & & & & & & & $\mathrm{x}$ \\
\hline Dead & & & & $\mathrm{X}$ & & & & & & & $\mathrm{X}$ \\
\hline
\end{tabular}

asT $=$ Subtidal,$\quad I T=$ Intertidal,$T I=$ Tidal,$\quad L P=$ Lower Perennial, UP=Upper Perennial, IN=Intermittent,$\quad L M=L$ Limnetic, LT $=$ Littoral.

mangle) and eastern oysters (Crassostrea virginica), are also included in the Estuarine System. ${ }^{3}$

Limits. The Estuarine System extends (1) upstream and landward to where ocean-derived salts measure less than $0.5 \%$ during the period of average annual low flow; (2) to an imaginary line closing the mouth of a river, bay, or sound; and (3) to the seaward limit of wetland emergents, shrubs, or trees where they are not included in (2). The Estuarine System also includes offshore areas of continuously diluted sea water.

Description. The Estuarine System includes both estuaries and lagoons. It is more strongly influenced by its association with land than is the Marine System. In terms of wave action, estuaries are generally considered to be low-energy systems (Chapman 1977:2).

Estuarine water regimes and water chemistry are affected by one or more of the following forces: oceanic tides, precipitation, freshwater runoff from land areas, evaporation, and wind. Estuarine salinities range from hyperhaline to oligohaline (Table 2). The salinity may be variable, as in hyperhaline lagoons (e.g., Laguna Madre, Texas) and most brackish estuaries (e.g., Chesapeake Bay, Virginia-Maryland); or it may be relatively stable, as in sheltered euhaline embayments (e.g., Chincoteague Bay, Maryland) or brackish embayments with partly obstructed access or small tidal range (e.g., Pamlico Sound, North Carolina). (For an extended discussion of estuaries and lagoons see Lauff 1967.)

\section{Subsystems.}

Subtidal.-The substrate is continuously submerged. Intertidal. - The substrate is exposed and flooded by tides; includes the associated splash zone.

${ }^{3}$ The Coastal Zone Management Act of 1972 defines an estuary as "that part of a river or stream or other body of water having unimpaired connection with the open sea, where the sea-water is measurably diluted with freshwater derived from land drainage." The Act further states that "the term includes estuarytype areas of the Great Lakes." However, in the present system we do not consider areas of the Great Lakes as Estuarine.
Classes. Rock Bottom, Unconsolidated Bottom, Aquatic Bed, Reef, Streambed, Rocky Shore, Unconsolidated Shore, Emergent Wetland, Scrub-Shrub Wetland, and Forested Wetland.

\section{Riverine System}

Definition. The Riverine System (Fig. 4) includes all wetlands and deepwater habitats contained within a channel, with two exceptions: (1) wetlands dominated by trees, shrubs, persistent emergents, emergent mosses, or lichens, and (2) habitats with water containing oceanderived salts in excess of $0.5 \%$. A channel is "an open conduit either naturally or artificially created which periodically or continuously contains moving water, or which forms a connecting link between two bodies of standing water" (Langbein and Iseri 1960:5).

Limits. The Riverine System is bounded on the landward side by upland, by the channel bank (including natural and man-made levees), or by wetland dominated by trees, shrubs, persistent emergents, emergent mosses, or lichens. In braided streams, the system is bounded by the banks forming the outer limits of the depression within which the braiding occurs.

The Riverine System terminates at the downstream end where the concentration of ocean-derived salts in the water exceeds $0.5 \%$ during the period of annual average low flow, or where the channel enters a lake. It terminates at the upstream end where tributary streams originate, or where the channel leaves a lake. Springs discharging into a channel are considered part of the Riverine System.

Description. Water is usually, but not always, flowing in the Riverine System. Upland islands or Palustrine wetlands may occur in the channel, but they are not included in the Riverine System. Palustrine Moss-Lichen Wetlands, Emergent Wetlands, Scrub-Shrub Wetlands, and Forested Wetlands may occur adjacent to the Riverine System, often on a floodplain. Many biologists have suggested that all the wetlands occurring on the river floodplain should be a part of the Riverine System because they 


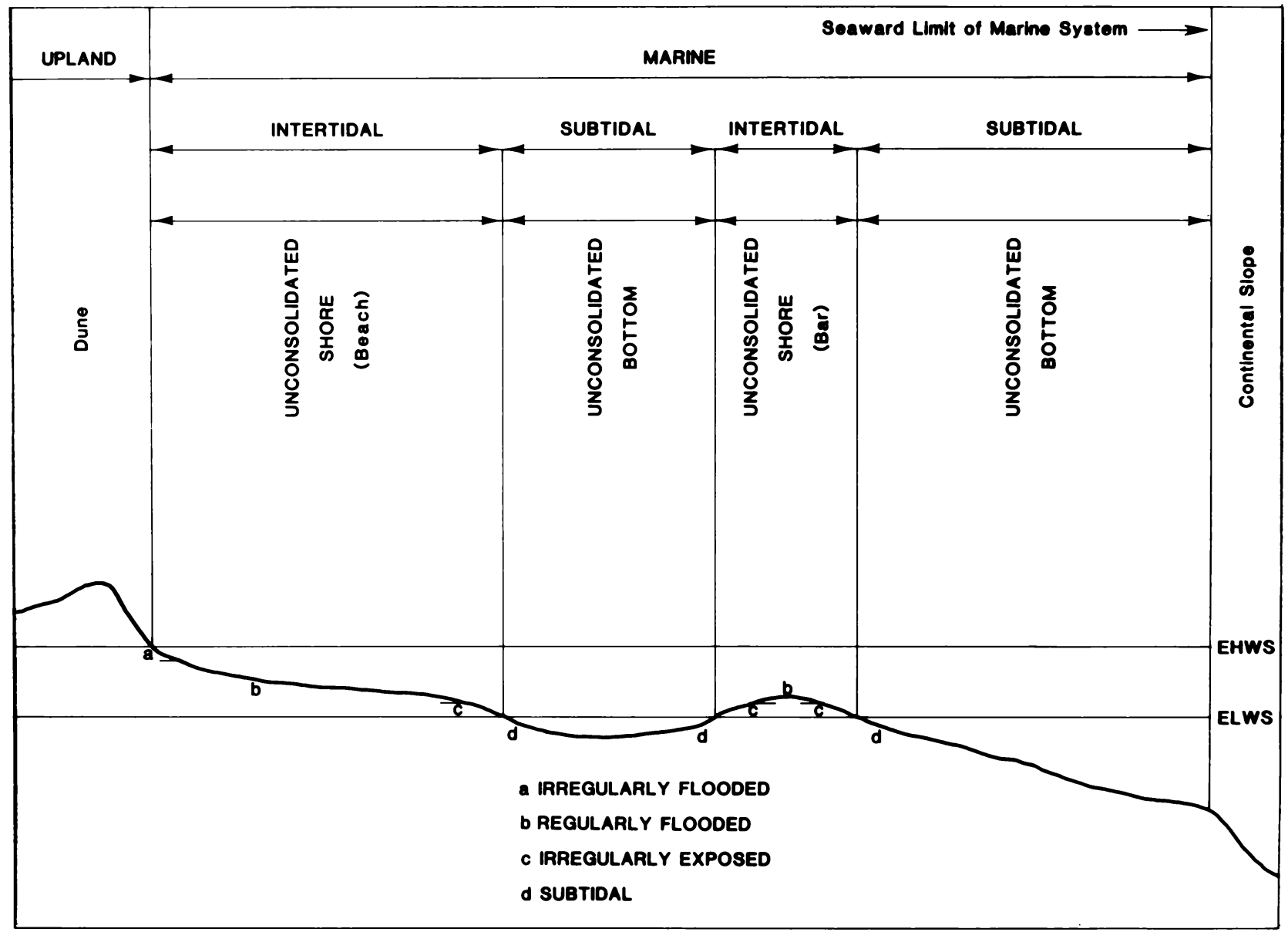

Fig. 2. Distinguishing features and examples of habitats in the Marine System. EHWS = extreme high water of spring tides; ELWS = extreme low water of spring tides.

consider their presence to be the result of river flooding. However, we concur with Reid and Wood $(1976: 72,84)$ who stated, "The floodplain is a flat expanse of land bordering an old river.... Often the floodplain may take the form of a very level plain occupied by the present stream channel, and it may never, or only occasionally, be flooded.... It is this subsurface water [the ground water] that controls to a great extent the level of lake surfaces, the flow of streams, and the extent of swamps and marshes."

Subsystems. The Riverine System is divided into four Subsystems: the Tidal, the Lower Perennial, the Upper Perennial, and the Intermittent. Each is defined in terms of water permanence, gradient, water velocity, substrate, and the extent of floodplain development. The Subsystems have characteristic flora and fauna (see Illies and Botosaneau 1963; Hynes 1970; Reid and Wood 1976). All four Subsystems are not necessarily present in all rivers, and the order of occurrence may be other than that given below.

Tidal. - The gradient is low and water velocity fluctuates under tidal influence. The streambed is mainly mud with occasional patches of sand. Oxygen deficits may sometimes occur and the fauna is similar to that in the Lower Peren- nial Subsystem. The floodplain is typically well developed.

Lower Perennial. -The gradient is low and water velocity is slow. There is no tidal influence, and some water flows throughout the year. The substrate consists mainly of sand and mud. Oxygen deficits may sometimes occur, the fauna is composed mostly of species that reach their maximum abundance in still water, and true planktonic organisms are common. The gradient is lower than that of the Upper Perennial Subsystem and the floodplain is well developed.

Upper Perennial. - The gradient is high and velocity of the water fast. There is no tidal influence and some water flows throughout the year. The substrate consists of rock, cobbles, or gravel with occasional patches of sand. The natural dissolved oxygen concentration is normally near saturation. The fauna is characteristic of running water, and there are few or no planktonic forms. The gradient is high compared with that of the Lower Perennial Subsystem, and there is very little floodplain development.

Intermittent.-In this Subsystem, the channel contains flowing water for only part of the year. When the water is not flowing, it may remain in isolated pools or surface water may be absent. 


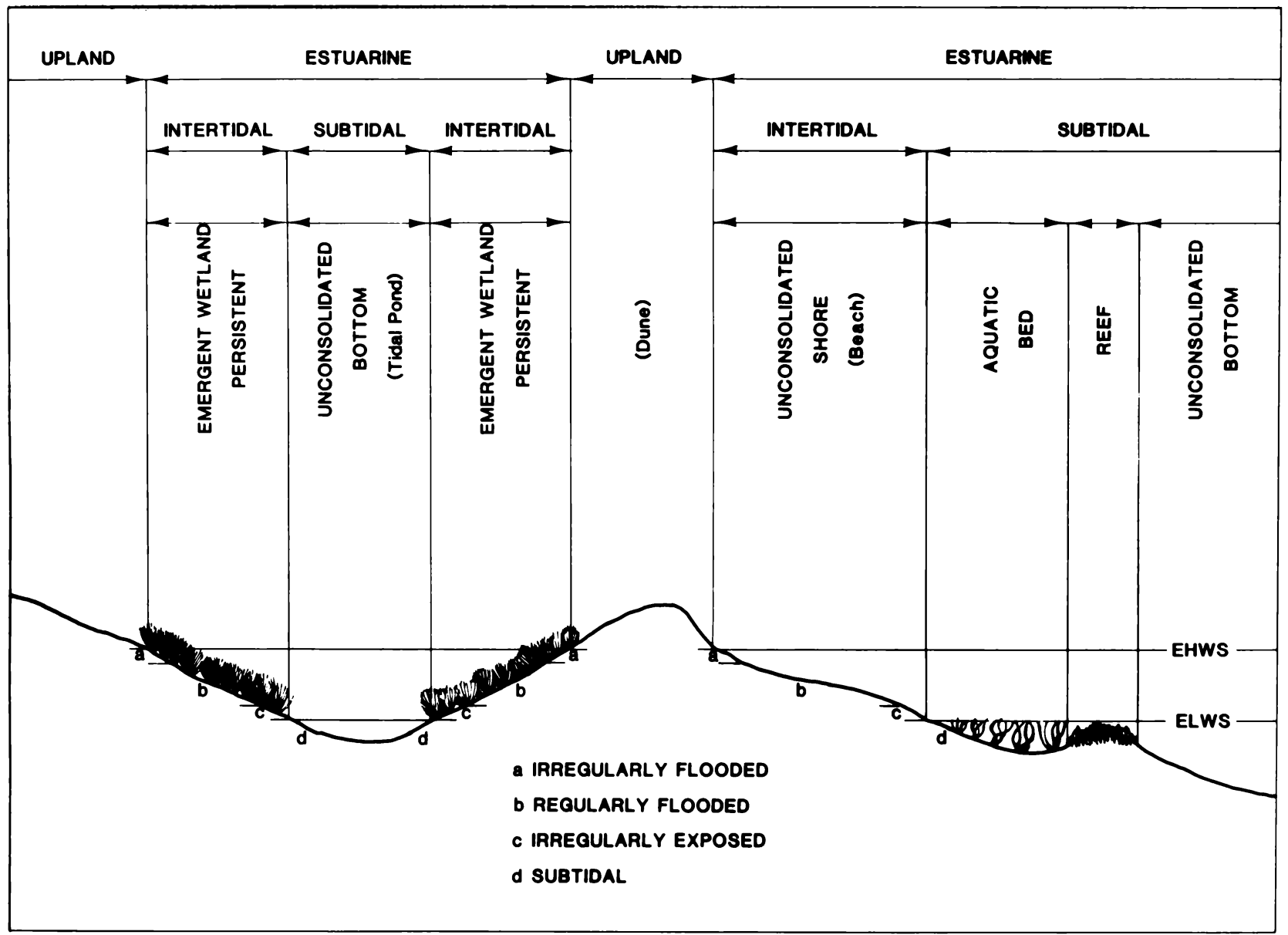

Fig. 3. Distinguishing features and examples of habitats in the Estuarine System. EHWS = extreme high water of spring tides; ELWS $=$ extreme low water of spring tides.

Classes. Rock Bottom, Unconsolidated Bottom, Aquatic Bed, Streambed, Rocky Shore, Unconsolidated Shore, and Emergent Wetland (nonpersistent).

\section{Lacustrine System}

Definition. The Lacustrine System (Fig. 5) includes wetlands and deepwater habitats with all of the following characteristics: (1) situated in a topographic depression or a dammed river channel; (2) lacking trees, shrubs, persistent emergents, emergent mosses or lichens with greater than $30 \%$ areal coverage; and (3) total area exceeds 8 ha $(20$ acres). Similar wetland and deepwater habitats totaling less than 8 ha are also included in the Lacustrine System if an active wave-formed or bedrock shoreline feature makes up all or part of the boundary, or if the water depth in the deepest part of the basin exceeds $2 \mathrm{~m}$ ( 6.6 feet) at low water. Lacustrine waters may be tidal or nontidal, but ocean-derived salinity is always less than $0.5 \%$.

Limits. The Lacustrine System is bounded by upland or by wetland dominated by trees, shrubs, persistent emergents, emergent mosses, or lichens. Lacustrine Systems formed by damming a river channel are bounded by a contour approximating the normal spillway elevation or normal pool elevation, except where Palustrine wetlands extend lakeward of that boundary. Where a river enters a lake, the extension of the Lacustrine shoreline forms the Riverine-Lacustrine boundary.

Description. The Lacustrine System includes permanently flooded lakes and reservoirs (e.g., Lake Superior), intermittent lakes (e.g., playa lakes), and tidal lakes with ocean-derived salinities below $0.5 \%$ (e.g., Grand Lake, Louisiana). Typically, there are extensive areas of deep water and there is considerable wave action. Islands of Palustrine wetland may lie within the boundaries of the Lacustrine System.

\section{Subsystems.}

Limnetic. - All deepwater habitats within the Lacustrine System; many small Lacustrine Systems have no Limnetic Subsystem.

Littoral.-All wetland habitats in the Lacustrine System. Extends from the shoreward boundary of the 
Table 2. Salinity Modifiers used in this classification system.

\begin{tabular}{lccc}
\hline Coastal Modifiers & & & $\begin{array}{c}\text { Approximate } \\
\text { specific conductance } \\
\left(\mu \text { Mhos at } 25^{\circ} \mathrm{C}\right)\end{array}$ \\
\hline Hyperhaline & Inland Modifiers $^{\mathrm{b}}$ & Salinity $^{\text {(parts per thousand) }}$ & $>60,000$ \\
Euhaline & Hypersaline & $>40$ & $45,000-60,000$ \\
Mixohaline (Brackish) & Eusaline & $30.0-40$ & $800-45,000$ \\
Polyhaline & Mixosaline $^{\mathrm{c}}$ & $0.5-30$ & $30,000-45,000$ \\
Mesohaline & Polysaline & $18.0-30$ & $8,000-30,000$ \\
Oligohaline & Mesosaline & $5.0-18$ & $800-8,000$ \\
Fresh & Oligosaline & $0.5-5$ & $<800$ \\
\hline
\end{tabular}

${ }^{a}$ Coastal Modifiers are used in the Marine and Estuarine Systems.

bInland Modifiers are used in the Riverine, Lacustrine, and Palustrine Systems.

'The term Brackish should not be used for inland wetlands or deepwater habitats.

system to a depth of $2 \mathrm{~m}$ (6.6 feet) below low water or to the maximum extent of nonpersistent emergents, if these grow at depths greater than $2 \mathrm{~m}$.

Classes. Rock Bottom, Unconsolidated Bottom, Aquatic Bed, Rocky Shore, Unconsolidated Shore, and Emergent Wetland (nonpersistent).

\section{Palustrine System}

Definition. The Palustrine System (Fig. 6) includes all nontidal wetlands dominated by trees, shrubs, persistent emergents, emergent mosses or lichens, and all such wetlands that occur in tidal areas where salinity due to oceanderived salts is below $0.5 \%$. It also includes wetlands lacking such vegetation, but with all of the following four characteristics: (1) area less than 8 ha (20 acres); (2) active wave-formed or bedrock shoreline features lacking; (3) water depth in the deepest part of basin less than $2 \mathrm{~m}$ at low water; and (4) salinity due to ocean-derived salts less than $0.5 \%$.

Limits. The Palustrine System is bounded by upland or by any of the other four Systems.

Description. The Palustrine System was developed to group the vegetated wetlands traditionally called by such names as marsh, swamp, bog, fen, and prairie, which are found throughout the United States. It also includes the small, shallow, permanent or intermittent water bodies often called ponds. Palustrine wetlands may be situated shoreward of lakes, river channels, or estuaries; on river floodplains; in isolated catchments; or on slopes. They may also occur as islands in lakes or rivers. The erosive forces of wind and water are of minor importance except during severe floods.

The emergent vegetation adjacent to rivers and lakes is often referred to as "the shore zone" or the "zone of emergent vegetation" (Reid and Wood 1976), and is generally considered separately from the river or lake. As an example, Hynes (1970:85) wrote in reference to riverine habitats, "We will not here consider the long list of emergent plants which may occur along the banks out of the current, as they do not belong, strictly speaking, to the running water habitat." There are often great similarities between wetlands lying adjacent to lakes or rivers and isolated wetlands of the same class in basins without open water.

\section{Subsystems. None.}

Classes. Rock Bottom, Unconsolidated Bottom, Aquatic Bed, Unconsolidated Shore, Moss-Lichen Wetland, Emergent Wetland, Scrub-Shrub Wetland, and Forested Wetland.

\section{Classes, Subclasses, and Dominance Types}

The CLASS is the highest taxonomic unit below the Subsystem level. It describes the general appearance of the habitat in terms of either the dominant life form of the vegetation or the physiography and composition of the substrate-features that can be recognized without the aid of detailed environmental measurements. Vegetation is used at two different levels in the classification. The life forms-trees, shrubs, emergents, emergent mosses, and lichens-are used to define Classes because they are relatively easy to distinguish, do not change distribution rapidly, and have traditionally been used as criteria for classification of wetlands. ${ }^{4}$ Other forms of vegetation, such as submerged or floating-leaved rooted vascular plants, free-floating vascular plants, submergent mosses, and algae, though frequently more difficult to detect, are used

${ }^{4}$ Our initial attempts to use familiar terms such as marsh, swamp, bog, and meadow at the Class level were unsuccessful primarily because of wide discrepancies in the use of these terms in various regions of the United States. In an effort to resolve that difficulty, we based the Classes on the fundamental components (life form, water regime, substrate type, water chemistry) that give rise to such terms. We believe that this approach will greatly reduce the misunderstandings and confusion that result from the use of the familiar terms. 


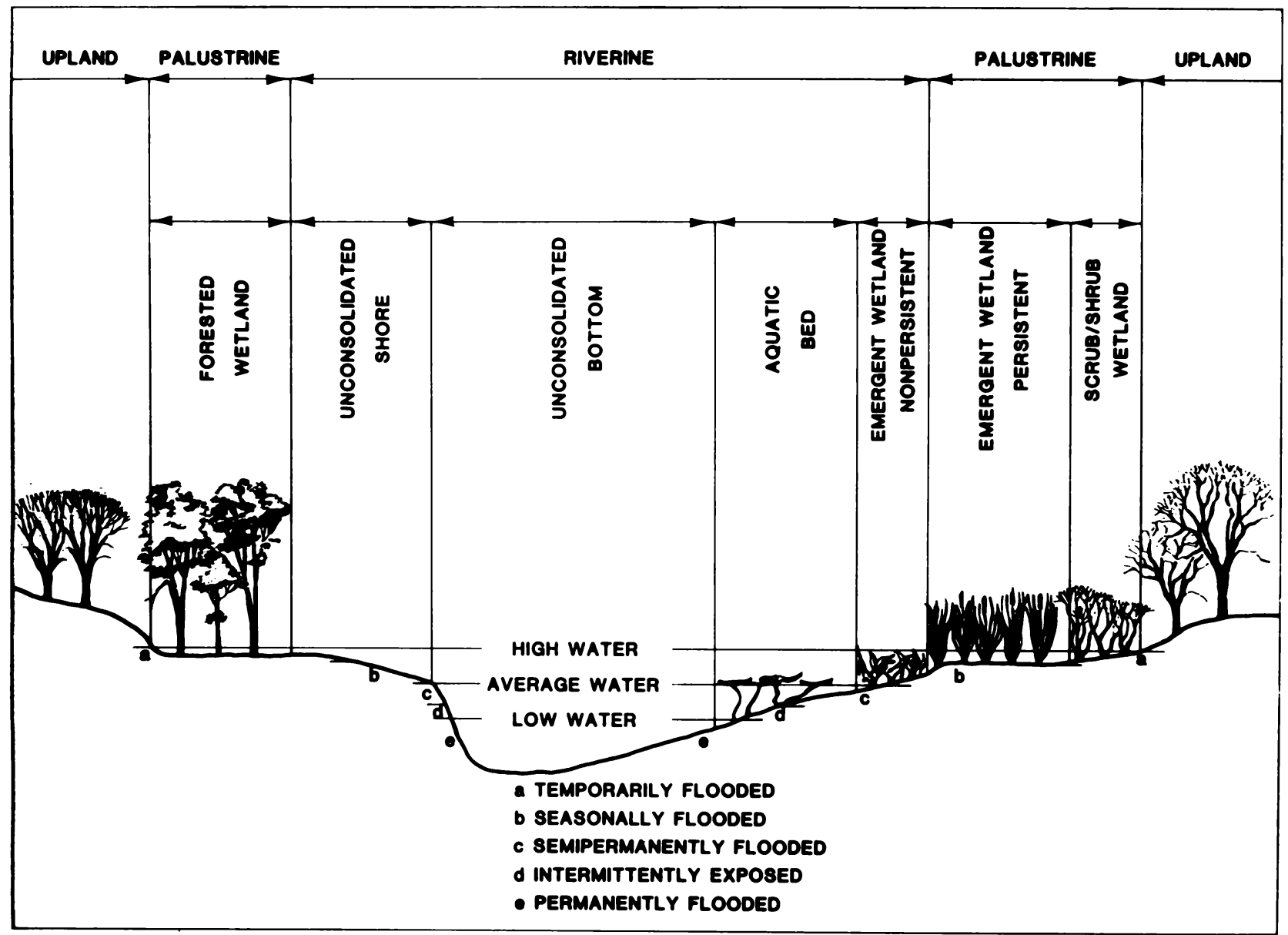

Fig. 4. Distinguishing features and examples of habitats in the Riverine System.

to define the Class Aquatic Bed. Pioneer species that briefly invade wetlands when conditions are favorable are treated at the Subclass level because they are transient and often not true wetland species.

Use of life forms at the Class level has two major advantages: (1) extensive biological knowledge is not required to distinguish between various life forms, and (2) it has been established that various life forms are easily recognizable on a great variety of remote sensing products (e.g., Radforth 1962; Anderson et al. 1976). If vegetation (except pioneer species) covers $30 \%$ or more of the substrate, we distinguish Classes on the basis of the life form of the plants that constitute the uppermost layer of vegetation and that possess an areal coverage $30 \%$ or greater. For example, an area with $50 \%$ areal coverage of trees over a shrub layer with a $60 \%$ areal coverage would be classified as Forested Wetland; an area with $20 \%$ areal coverage of trees over the same $(60 \%)$ shrub layer would be classified as Scrub-Shrub Wetland. When trees or shrubs alone cover less than $30 \%$ of an area but in combination cover $30 \%$ or more, the wetland is assigned to the Class Scrub-Shrub. When trees and shrubs cover less than $30 \%$ of the area but the total cover of vegetation (except pioneer species) is $30 \%$ or greater, the wetland is assigned to the appropriate Class for the predominant life form below the shrub layer. Finer differences in life forms are recognized at the SUBCLASS level. For example, Forested Wetland is divided into the Subclasses Broad-leaved Deciduous, Needle-leaved Deciduous, Broad-leaved Evergreen, Needle-leaved Evergreen, and Dead. Subclasses are named on the basis of the predominant life form.

If vegetation covers less than $30 \%$ of the substrate, the physiography and composition of the substrate are the principal characteristics used to distinguish Classes. The nature of the substrate reflects regional and local variations in geology and the influence of wind, waves, and currents on erosion and deposition of substrate materials. Bottoms, Shores, and Streambeds are separated on the basis of duration of inundation. In the Riverine, Lacustrine, and Palustrine Systems, Bottoms are submerged all or most of the time, whereas Streambeds and Shores are exposed all or most of the time. In the Marine and Estuarine Systems, Bottoms are Subtidal, whereas Streambeds and Shores are Intertidal. Bottoms, Shores, and Streambeds are further divided at the Class level on the basis of the important characteristic of rock versus 


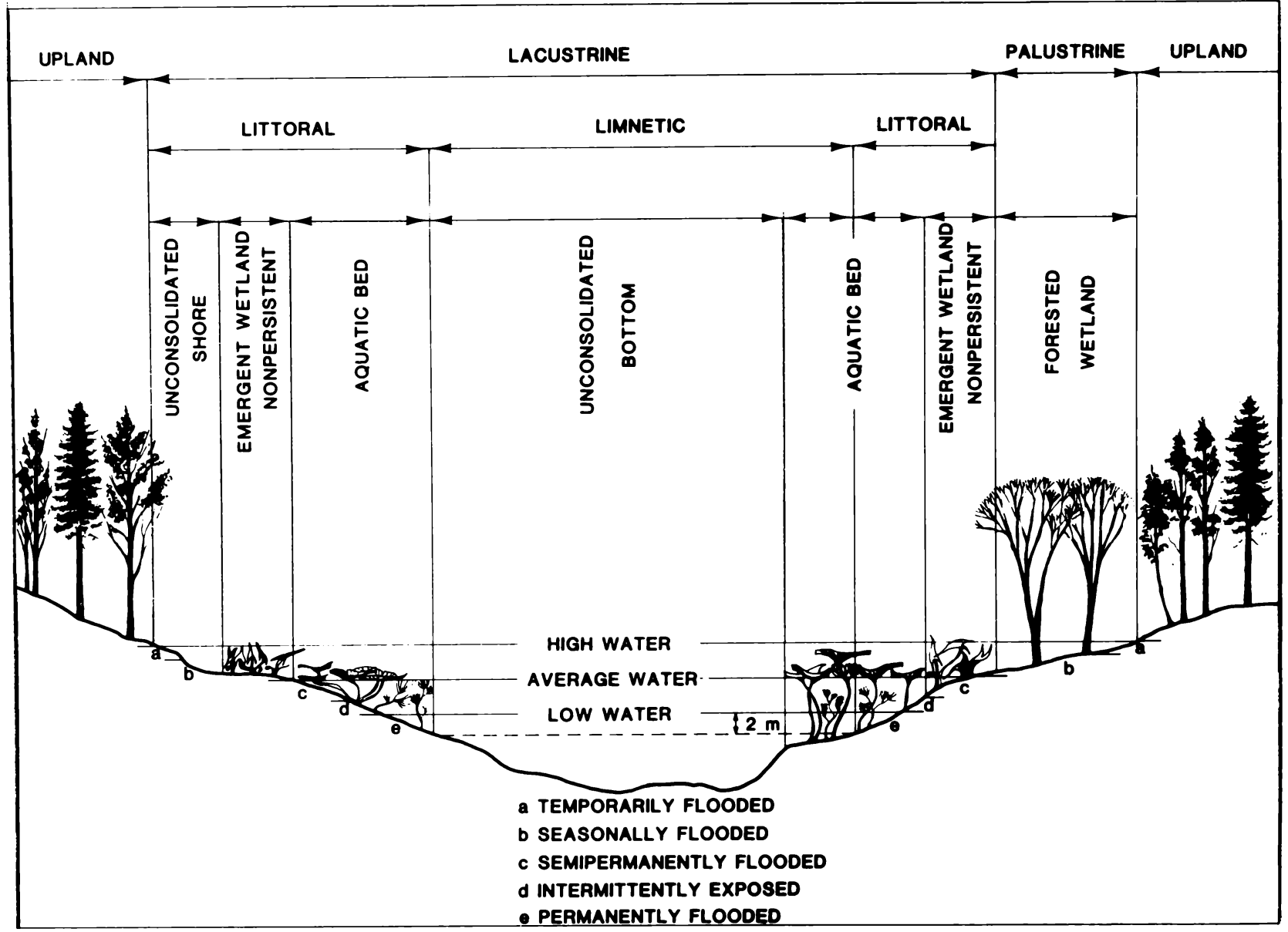

Fig. 5. Distinguishing features and examples of habitats in the Lacustrine System.

unconsolidated substrate. Subclasses are based on finer distinctions in substrate material unless, as with Streambeds and Shores, the substrate is covered by, or shaded by, an areal coverage of pioneering vascular plants (often nonhydrophytes) of $30 \%$ or more; the Subclass is then simply "vegetated." Further detail as to the type of vegetation must be obtained at the level of Dominance Type. Reefs are a unique class in which the substrate itself is composed primarily of living and dead animals. Subclasses of Reefs are designated on the basis of the type of organism that formed the reef.

The DOMINANCE TYPE is the taxonomic category subordinate to Subclass. Dominance Types are determined on the basis of dominant plant species (e.g., Jeglum et al. 1974), dominant sedentary or sessile animal species (e.g., Thorson 1957), or dominant plant and animal species (e.g., Stephenson and Stephenson 1972). A dominant plant species has traditionally meant one that has control over the community (Weaver and Clements 1938:91), and this plant is also usually the predominant species (Cain and Castro 1959:29). When the Subclass is based on life form, we name the Dominance Type for the dominant species or combination of species (codominants) in the same layer of vegetation used to determine the Subclass. ${ }^{5}$ For example, a Needle-leaved Evergreen Forested Wetland with $70 \%$ areal cover of black spruce (Picea mariana) and $30 \%$ areal cover of tamarack (Larix laricina) would be designated as a Picea mariana Dominance Type. When the relative abundance of codominant species is nearly equal, the Dominance Type consists of a combination of species names. For example, an Emergent Wetland with about equal areal cover of common cattail (Typha latifolia) and hardstem bulrush (Scirpus acutus) would be designated a Typha latifolia-Scirpus acutus Dominance Type.

When the Subclass is based on substrate material, the Dominance Type is named for the predominant plant or

${ }^{5}$ Percent areal cover is seldom measured in the application of this system, but the term must be defined in terms of area. We suggest $2 \mathrm{~m}^{2}$ for herbaceous and moss layers, $16 \mathrm{~m}^{2}$ for shrub layers, and $100 \mathrm{~m}^{2}$ for tree layers (Mueller-Dombois and Ellenberg 1974:74). When percent areal cover is the key for establishing boundaries between units of the classification, it may occasionally be necessary to measure cover on plots, in order to maintain uniformity of ocular estimates made in the field or interpretations made from aerial photographs. 


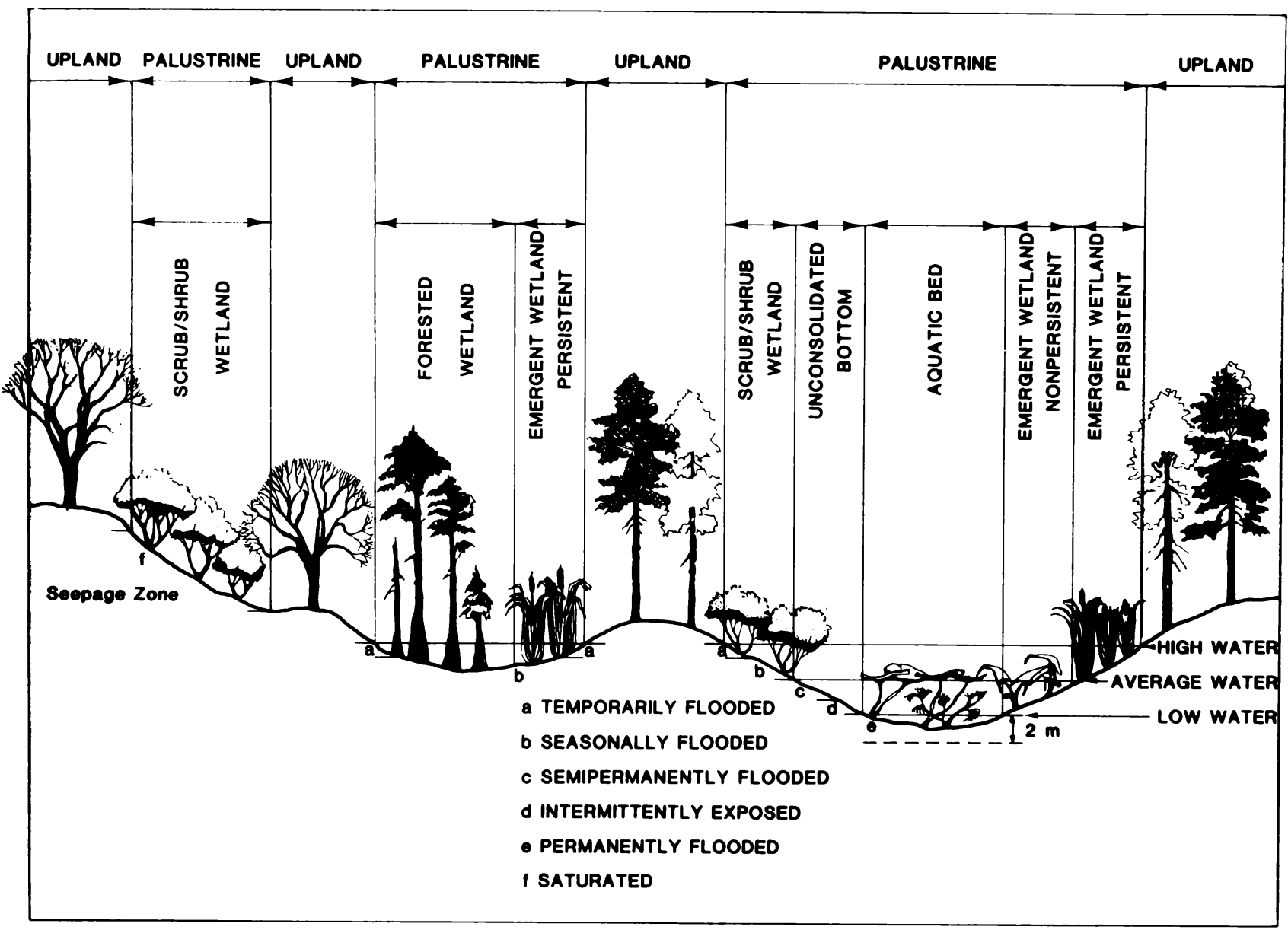

Fig. 6. Distinguishing features and examples of habitats in the Palustrine System.

sedentary or sessile macroinvertebrate species, without regard for life form. In the Marine and Estuarine Systems, sponges, alcyonarians, mollusks, crustaceans, worms, ascidians, and echinoderms may all be part of the community represented by the Macoma balthica Dominance Type. Sometimes it is necessary to designate two or more codominant species as a Dominance Type. Thorson (1957) recommended guidelines and suggested definitions for establishing community types and dominants on level bottoms.

\section{Rock Bottom}

Definition. The Class Rock Bottom includes all wetlands and deepwater habitats with substrates having an areal cover of stones, boulders, or bedrock $75 \%$ or greater and vegetative cover of less than $30 \%$. Water regimes are restricted to subtidal, permanently flooded, intermittently exposed, and semipermanently flooded.

Description. The rock substrate of the rocky benthic or bottom zone is one of the most important factors in determining the abundance, variety, and distribution of organisms. The stability of the bottom allows a rich assemblage of plants and animals to develop. Rock Bottoms are usually high-energy habitats with well-aerated waters. Temperature, salinity, current, and light penetration are also important factors in determining the composition of the benthic community. Animals that live on the rocky surface are generally firmly attached by hooking or sucking devices, although they may occasionally move about over the substrate. Some may be permanently attached by cement. A few animals hide in rocky crevices and under rocks, some move rapidly enough to avoid being swept away, and others burrow into the finer substrates between boulders. Plants are also firmly attached (e.g., by holdfasts), and in the Riverine System both plants and animals are commonly streamlined or flattened in response to high water velocities.

\section{Subclasses and Dominance Types.}

Bedrock.-Bottoms in which bedrock covers $75 \%$ or more of the surface.

Rubble.-Bottoms with less than $75 \%$ areal cover of bedrock, but stones and boulders alone, or in combination with bedrock, cover $75 \%$ or more of the surface.

Examples of Dominance Types for these two Subclasses in the Marine and Estuarine Systems are the encrusting 
sponges Hippospongia, the tunicate Cnemidocarpa, the sea urchin Strongylocentrotus, the sea star Pisaster, the sea whip Muricea, and the American lobster Homarus americanus. Examples of Lacustrine, Palustrine, and Riverine Dominance Types are the freshwater sponges Spongilla and Heteromeyenia, the pond snail Lymnaea, the mayfly Ephemerella, various midges of the Chironomidae, the caddisfly Hydropsyche, the leech Helobdella, the riffle beetle Psephenus, the chironomid midge Eukiefferiella, the crayfish Procambarus, and the black fly Simulium.

Dominance Types for Rock Bottoms in the Marine and Estuarine Systems were taken primarily from Smith (1964) and Ricketts and Calvin (1968), and those for Rock Bottoms in the Lacustrine, Riverine, and Palustrine Systems from Krecker and Lancaster (1933), Stehr and Branson (1938), Ward and Whipple (1959), Clarke (1973), Hart and Fuller (1974), Ward (1975), Slack et al. (1977), and Pennak (1978).

\section{Unconsolidated Bottom}

Definition. The Class Unconsolidated Bottom includes all wetland and deepwater habitats with at least $25 \%$ cover of particles smaller than stones, and a vegetative cover less than $30 \%$. Water regimes are restricted to subtidal, permanently flooded, intermittently exposed, and semipermanently flooded.

Description. Unconsolidated Bottoms are characterized by the lack of large stable surfaces for plant and animal attachment. They are usually found in areas with lower energy than Rock Bottoms, and may be very unstable. Exposure to wave and current action, temperature, salinity, and light penetration determines the composition and distribution of organisms.

Most macroalgae attach to the substrate by means of basal hold-fast cells or discs; in sand and mud, however, algae penetrate the substrate and higher plants can successfully root if wave action and currents are not too strong. Most animals in unconsolidated sediments live within the substrate, e.g., Macoma and the amphipod Melita. Some, such as the polychaete worm Chaetopterus, maintain permanent burrows, and others may live on the surface, especially in coarse-grained sediments.

In the Marine and Estuarine Systems, Unconsolidated Bottom communities are relatively stable. They vary from the Arctic to the tropics, depending largely on temperature, and from the open ocean to the upper end of the estuary, depending on salinity. Thorson (1957) summarized and described characteristic types of level-bottom communities in detail.

In the Riverine System, the substrate type is largely determined by current velocity, and plants and animals exhibit a high degree of morphologic and behavioral adaptation to flowing water. Certain species are confined to specific substrates and some are at least more abundant in one type of substrate than in others. According to Hynes (1970:208), "The larger the stones, and hence the more complex the substratum, the more diverse is the invertebrate fauna." In the Lacustrine and Palustrine Systems, there is usually a high correlation, within a given water body, between the nature of the substrate and the number of species and individuals. For example, in the profundal bottom of eutrophic lakes where light is absent, oxygen content is low, and carbon dioxide concentration is high, the sediments are ooze-like organic materials and species diversity is low. Each substrate type typically supports a relatively distinct community of organisms (Reid and Wood 1976:262).

Subclasses and Dominance Types.

Cobble-Gravel.-The unconsolidated particles smaller than stones are predominantly cobble and gravel, although finer sediments may be intermixed. Examples of Dominance Types for the Marine and Estuarine Systems are the mussels Modiolus and Mytilus, the brittle star Amphipholis, the soft-shell clam Mya, and the Venus clam Saxidomus. Examples for the Lacustrine, Palustrine, and Riverine Systems are the midge Diamesa, stonefly-midge Nemoura-Eukiefferiella (Slack et al. 1977), chironomid midge-caddisfly-snail Chironomus-Hydropsyche-Physa (Krecker and Lancaster 1933), the pond snail Lymnaea, the mayfly Baetis, the freshwater sponge Eunapius, the oligochaete worm Lumbriculus, the scud Gammarus, and the freshwater mollusks Anodonta, Elliptio, and Lampsilis.

Sand.-The unconsolidated particles smaller than stones are predominantly sand, although finer or coarser sediments may be intermixed. Examples of Dominance Types in the Marine and Estuarine Systems are the wedge shell Donax, the scallop Pecten, the tellin shell Tellina, the heart urchin Echinocardium, the lugworm Arenicola, the sand dollar Dendraster, and the sea pansy Renilla. Examples for the Lacustrine, Palustrine, and Riverine Systems are the snail Physa, the scud Gammarus, the oligochaete worm Limnodrilus, the mayfly Ephemerella, the freshwater mollusks Elliptio and Anodonta, and the fingernail clam Sphaerium.

Mud.-The unconsolidated particles smaller than stones are predominantly silt and clay, although coarser sediments or organic material may be intermixed. Organisms living in mud must be able to adapt to low oxygen concentrations. Examples of Dominance Types for the Marine and Estuarine Systems include the terebellid worm Amphitrite, the boring clam Platyodon, the deep-sea scallop Placopecten, the quahog Mercenaria, the macoma Macoma, the echiurid worm Urechis, the mud snail Nassarius, and the sea cucumber Thyone. Examples of Dominance Types for the Lacustrine, Palustrine, and Riverine Systems are the sewage worm Tubifex, freshwater mollusks Anodonta, Anodontoides, and Elliptio, the fingernail clams Pisidium and Sphaerium, and the midge Chironomus. 
Organic.-The unconsolidated material smaller than stones is predominantly organic. The number of species is limited and faunal productivity is very low (Welch 1952). Examples of Dominance Types for Estuarine and Marine Systems are the soft-shell clam Mya, the false angel wing Petricola pholadiformis, the clam worm Nereis, and the mud snail Nassarius. Examples for the Lacustrine, Palustrine, and Riverine Systems are the sewage worm Tubifex, the snail Physa, the harpacticoid copepod Canthocamptus, and the oligochaete worm Limnodrilus.

Dominance Types for Unconsolidated Bottoms in the Marine and Estuarine Systems were taken predominantly from Miner (1950), Smith (1964), Abbott (1968), and Ricketts and Calvin (1968). Dominance Types for Unconsolidated Bottoms in the Lacustrine, Riverine, and Palustrine Systems were taken predominantly from Krecker and Lancaster (1933), Stehr and Branson (1938), Johnson (1970), Brinkhurst and Jamieson (1972), Clarke (1973), Hart and Fuller (1974), Ward (1975), and Pennak (1978).

\section{Aquatic Bed}

Definition. The Class Aquatic Bed includes wetlands and deepwater habitats dominated by plants that grow principally on or below the surface of the water for most of the growing season in most years. Water regimes include subtidal, irregularly exposed, regularly flooded, permanently flooded, intermittently exposed, semipermanently flooded, and seasonally flooded.

Description. Aquatic Beds represent a diverse group of plant communities that requires surface water for optimum growth and reproduction. They are best developed in relatively permanent water or under conditions of repeated flooding. The plants are either attached to the substrate or float freely in the water above the bottom or on the surface.

Subclasses and Dominance Types.

Algal.-Algal Beds are widespread and diverse in the Marine and Estuarine Systems, where they occupy substrates characterized by a wide range of sediment depths and textures. They occur in both the Subtidal and Intertidal Subsystems and may grow to depths of $30 \mathrm{~m}$ (98 feet). Coastal Algal Beds are most luxuriant along the rocky shores of the Northeast and West. Kelp (Macrocystis) beds are especially well developed on the rocky substrates of the Pacific Coast. Dominance Types such as the rockweeds Fucus and Ascophyllum and the kelp Laminaria are common along both coasts. In tropical regions, green algae, including forms containing calcareous particles, are more characteristic; Halimeda and Penicillus are common examples. The red alga Laurencia, and the green algae Caulerpa, Enteromorpha, and Ulva are also common Estuarine and Marine dominance types; Enteromorpha and Ulva are tolerant of fresh water and flourish near the upper end of some estuaries. The stonewort Chara is also found in estuaries.
Inland, the stoneworts Chara, Nitella, and Tolypella are examples of algae that look much like vascular plants and may grow in similar situations. However, meadows of Chara may be found in Lacustrine water as deep as $40 \mathrm{~m}$ (131 feet) (Zhadin and Gerd 1963), where hydrostatic pressure limits the survival of vascular submergents (phanaerogams) (Welch 1952). Other algae bearing less resemblance to vascular plants are also common. Mats of filamentous algae may cover the bottom in dense blankets, may rise to the surface under certain conditions, or may become stranded on Unconsolidated or Rocky Shores.

Aquatic Moss. -Aquatic mosses are far less abundant than algae or vascular plants. They occur primarily in the Riverine System and in permanently flooded and intermittently exposed parts of some Lacustrine systems. The most important Dominance Types include genera such as Fissidens, Drepanocladus, and Fontinalis. Fontinalis may grow to depths as great as $120 \mathrm{~m}$ (394 feet) (Hutchinson 1975). For simplicity, aquatic liverworts of the genus Marsupella are included in this Subclass.

Rooted Vascular.-Rooted Vascular Beds include a large array of vascular species in the Marine and Estuarine Systems. They have been referred to by others as temperate grass flats (Phillips 1974); tropical marine meadows (Odum 1974); and eelgrass beds, turtlegrass beds, and seagrass beds (Akins and Jefferson 1973; Eleuterius 1973; Phillips 1974). The greatest number of species occur in shallow, clear tropical, or subtropical waters of moderate current strength in the Caribbean and along the Florida and Gulf Coasts. Principal Dominance Types in these areas include turtle grass (Thalassia testudinum), shoalgrass (Halodule wrightii), manatee grass (Cymodocea filiformis), widgeon grass (Ruppia maritima), sea grasses (Halophila spp.), and wild celery (Vallisneria americana).

Five major vascular species dominate along the temperate coasts of North America: shoalgrass, surf grasses (Phyllospadix scouleri, P. torreyi), widgeon grass, and eelgrass (Zostera marina). Eelgrass beds have the most extensive distribution, but they are limited primarily to the more sheltered estuarine environment. In the lower salinity zones of estuaries, stands of widgeon grass, pondweed (Potamogeton), and wild celery often occur, along with naiads (Najas) and water milfoil (Myriophyllum).

In the Riverine, Lacustrine, and Palustrine Systems, rooted vascular aquatic plants occur at all depths within the photic zone. They often occur in sheltered areas where there is little water movement (Wetzel 1975); however, they also occur in the flowing water of the Riverine System, where they may be streamlined or flattened in response to high water velocities. Typical inland genera include pondweeds, horned pondweed (Zannichellia palustris), ditch grasses (Ruppia), wild celery, and waterweed (Elodea). The riverweed (Podostemum ceratophyllum) is included in this class despite its lack of truly recognizable roots (Sculthorpe 1967). 
Some of the rooted vascular species are characterized by floating leaves. Typical dominants include water lilies (Nymphaea, Nuphar), floating-leaf pondweed (Potamogeton natans), and water shield (Brasenia schreberi). Plants such as yellow water lily (Nuphar luteum) and water smartweed (Polygonum amphibium), which may stand erect above the water surface or substrate, may be considered either emergents or rooted vascular aquatic plants, depending on the life form adopted at a particular site.

Floating Vascular.-Beds of floating vascular plants occur mainly in the Lacustrine, Palustrine, and Riverine Systems and in the fresher waters of the Estuarine System. The plants float freely either in the water or on its surface. Dominant plants that float on the surface include the duckweeds (Lemna, Spirodela), water lettuce (Pistia stratiotes), water hyacinth (Eichhornia crassipes), water nut (Trapa natans), water ferns (Salvinia spp.), and mosquito ferns $($ Azolla). These plants are found primarily in protected portions of slow-flowing rivers and in the Lacustrine and Palustrine Systems. They are easily moved about by wind or water currents and cover a large area of water in some parts of the country, particularly the Southeast. Dominance Types for beds floating below the surface include bladderworts (Utricularia), coontails (Ceratophyllum), and watermeals (Wolffia) (Sculthorpe 1967; Hutchinson 1975).

\section{Reef}

Definition. The Class Reef includes ridge-like or moundlike structures formed by the colonization and growth of sedentary invertebrates. Water regimes are restricted to subtidal, irregularly exposed, regularly flooded, and irregularly flooded.

Description. Reefs are characterized by their elevation above the surrounding substrate and their interference with normal wave flow; they are primarily subtidal, but parts of some reefs may be intertidal as well. Although corals, oysters, and tube worms are the most visible organisms and are mainly responsible for reef formation, other mollusks, foraminifera, coralline algae, and other forms of life also contribute substantially to reef growth. Frequently, reefs contain far more dead skeletal material and shell fragments than living matter.

Subclasses and Dominance Types.

Coral.-Coral Reefs are widely distributed in shallow waters of warm seas, in Hawaii, Puerto Rico, the Virgin Islands, and southern Florida. They were characterized by Odum (1971) as stable, well-adapted, highly diverse, and highly productive ecosystems with a great degree of internal symbiosis. Coral Reefs lie almost entirely within the Subtidal Subsystem of the Marine System, although the upper part of certain Reefs may be exposed. Examples of Dominance Types are the corals Porites, Acropora, and Montipora. The distribution of these types reflects prim- arily their elevation, wave exposure, the age of the Reef, and its exposure to waves.

Mollusk.-This Subclass occurs in both the Intertidal and Subtidal Subsystems of the Estuarine System. These Reefs are found on the Pacific, Atlantic, and Gulf Coasts and in Hawaii and the Caribbean. Mollusk Reefs may become extensive, affording a substrate for sedentary and boring organisms and a shelter for many others. Reef mollusks are adapted to great variations in water level, salinity, and temperature, and these same factors control their distribution. Examples of Dominance Types for this Subclass are the oysters Ostrea and Crassostrea (Smith 1964; Abbott 1968; Ricketts and Calvin 1968).

Worm.-Worm Reefs are constructed by large colonies of Sabellariid worms living in individual tubes constructed from cemented sand grains. Although they do not support as diverse a biota as do Coral and Mollusk Reefs, they provide a distinct habitat which may cover large areas. Worm Reefs are generally confined to tropical waters, and are most common along the coasts of Florida, Puerto Rico, and the Virgin Islands. They occur in both the Intertidal and Subtidal Systems of the Marine and Estuarine Systems where the salinity approximates that of sea water. The reefworm Sabellaria is an example of a Dominance Type for this Subclass (Ricketts and Calvin 1968).

\section{Streambed}

Definition. The Class Streambed includes all wetland contained within the Intermittent Subsystem of the Riverine System and all channels of the Estuarine System or of the Tidal Subsystem of the Riverine System that are completely dewatered at low tide. Water regimes are restricted to irregularly exposed, regularly flooded, irregularly flooded, seasonally flooded, temporarily flooded, and intermittently flooded.

Description. Streambeds vary greatly in substrate and form depending on the gradient of the channel, the velocity of the water, and the sediment load. The substrate material frequently changes abruptly between riffles and pools, and complex patterns of bars may form on the convex side of single channels or be included as islands within the bed of braided streams (Crickmay 1974). In mountainous areas the entire channel may be cut through bedrock. In most cases streambeds are not vegetated because of the scouring effect of moving water, but, like Unconsolidated Shores, they may be colonized by "pioneering" annuals or perennials during periods of low flow or they may have perennial emergents and shrubs that are too scattered to qualify the area for classification as Emergent Wetland or Scrub-Shrub Wetland.

\section{Subclasses and Dominance Types.}

Bedrock.-This Subclass is characterized by a bedrock substrate covering $75 \%$ or more of the stream channel. 
It occurs most commonly in the Riverine System in high mountain areas or in glaciated areas where bedrock is exposed. Examples of Dominance Types are the mollusk $A n$ cylus, the oligochaete worm Limnodrilus, the snail Physa, the fingernail clam Pisidium, and the mayflies Caenis and Ephemerella.

Rubble.-This Subclass is characterized by stones, boulders, and bedrock that in combination cover more than $75 \%$ of the channel. Like Bedrock Streambeds, Rubble Streambeds are most common in mountainous areas and the dominant organisms are similar to those of Bedrock and are often forms capable of attachment to rocks in flowing water.

Cobble-Gravel.-In this Subclass at least $25 \%$ of the substrate is covered by unconsolidated particles smaller than stones; cobbles or gravel predominate. The Subclass occurs in riffle areas or in the channels of braided streams. Examples of Dominance Types in the Intermittent Subsystem of the Riverine System are the snail Physa, the oligochaete worm Limnodrilus, the mayfly Caenis, the midge Chironomus, and the mosquito Anopheles. Examples of Dominance Types in the Estuarine System or Tidal Subsystem of the Riverine System are the mussels Modiolus and Mytilus.

Sand.-In this Subclass, sand-sized particles predominate among the particles smaller than stones. Sand Streambed often contains bars and beaches interspersed with Mud Streambed or it may be interspersed with Cobble-Gravel Streambed in areas of fast flow or heavy sediment load. Examples of Dominance Types in the Riverine System are the scud Gammarus, the snails Physa and Lymnaea, and the midge Chironomus; in the Estuarine System the ghost shrimp Callianassa is a common Dominance Type.

Mud.-In this Subclass, the particles smaller than stones are chiefly silt or clay. Mud Streambeds are common in arid areas where intermittent flow is characteristic of streams of low gradient. Such species as tamarisk (Tamarix gallica) may occur, but are not dense enough to qualify the area for classification as Scrub-Shrub Wetland. Mud Streambeds are also common in the Estuarine System and the Tidal Subsystem of the Riverine System. Examples of Dominance Types for Mud Streambeds include the crayfish Procambarus, the pouch snail Aplexa, the fly Tabanus, the snail Lymnaea, the fingernail clam Sphaerium, and (in the Estuarine System) the mud snail Nassarius.

Organic. - This Subclass is characterized by channels formed in peat or muck. Organic Streambeds are common in the small creeks draining Estuarine Emergent Wetlands with organic soils. Examples of Dominance Types are the mussel Modiolus in the Estuarine System and the oligochaete worm Limnodrilus in the Riverine System.

Vegetated.-These streambeds are exposed long enough to be colonized by herbaceous annuals or seedling herbaceous perennials (pioneer plants). This vegetation, unlike that of Emergent Wetlands, is usually killed by rising water levels or sudden flooding. A typical Dominance Type is Panicum capillare.

Dominance Types for Streambeds in the Estuarine System were taken primarily from Smith (1964), Abbott (1968), and Ricketts and Calvin (1968) and those for streambeds in the Riverine System from Krecker and Lancaster (1933), Stehr and Branson (1938), van der Schalie (1948), Kenk (1949), Cummins et al. (1964), Clarke (1973), and Ward (1975).

\section{Rocky Shore}

Definition. The Class Rocky Shore includes wetland environments characterized by bedrock, stones, or boulders which singly or in combination have an areal cover of $75 \%$ or more and an areal coverage by vegetation of less than $30 \%$. Water regimes are restricted to irregularly exposed, regularly flooded, irregularly flooded, seasonally flooded, temporarily flooded, and intermittently flooded.

Description. In Marine and Estuarine Systems, Rocky Shores are generally high-energy habitats which lie exposed as a result of continuous erosion by wind-driven waves or strong currents. The substrate is stable enough to permit the attachment and growth of sessile or sedentary invertebrates and attached algae or lichens. Rocky Shores usually display a vertical zonation that is a function of tidal range, wave action, and degree of exposure to the sun. In the Lacustrine and Riverine Systems, Rocky Shores support sparse plant and animal communities.

Subclasses and Dominance Types.

Bedrock.-These wetlands have bedrock covering $75 \%$ or more of the surface and less than $30 \%$ areal coverage of macrophytes.

Rubble.-These wetlands have less than $75 \%$ areal cover of bedrock, but stones and boulders alone or in combination with bedrock cover $75 \%$ or more of the area. The areal coverage of macrophytes is less than $30 \%$.

Communities or zones of Marine and Estuarine Rocky Shores have been widely studied (Lewis 1964; Ricketts and Calvin 1968; Stephenson and Stephenson 1972). Each zone supports a rich assemblage of invertebrates and algae or lichens or both. Dominance Types of the Rocky Shores often can be characterized by one or two dominant genera from these zones.

The uppermost zone (here termed the littorine-lichen zone) is dominated by periwinkles (Littorina and Nerita) and lichens. This zone frequently takes on a dark, or even black appearance, although abundant lichens may lend a colorful tone. These organisms are rarely submerged, but are kept moist by sea spray. Frequently this habitat is invaded from the landward side by semimarine genera such as the slater Ligia.

The next lower zone (the balanoid zone) is commonly dominated by mollusks, green algae, and barnacles of the balanoid group. The zone appears white. Dominance Types 
such as the barnacles Balanus, Chthamalus, and Tetraclita may form an almost pure sheet, or these animals may be interspersed with mollusks, tube worms, and algae such as Pelvetia, Enteromorpha, and Ulva.

The transition between the littorine-lichen and balanoid zones is frequently marked by the replacement of the periwinkles with limpets such as Acmaea and Siphonaria. The limpet band approximates the upper limit of the regularly flooded intertidal zone.

In the middle and lower intertidal areas, which are flooded and exposed by tides at least once daily, lie a number of other communities which can be characterized by dominant genera. Mytilus and gooseneck barnacles (Pollicipes) form communities exposed to strong wave action. Aquatic Beds dominated by Fucus and Laminaria lie slightly lower, just above those dominated by coralline algae (Lithothamnion). The Laminaria Dominance Type approximates the lower end of the Intertidal Subsystem; it is generally exposed at least once daily. The Lithothamnion Dominance Type forms the transition to the Subtidal Subsystem and is exposed only irregularly.

In the Palustrine, Riverine, and Lacustrine Systems various species of lichens such as Verrucaria spp. and Dermatocarpon fluviatile, as well as blue-green algae, frequently form characteristic zones on Rocky Shores. The distribution of these species depends on the duration of flooding or wetting by spray and is similar to the zonation of species in the Marine and Estuarine Systems (Hutchinson 1975). Though less abundant than lichens, aquatic liverworts such as Marsupella emarginata var. aquatica or mosses such as Fissidens julianus are found on the Rocky Shores of lakes and rivers. If aquatic liverworts or mosses cover $30 \%$ or more of the substrate, they should be placed in the Class Aquatic Bed. Other examples of Rocky Shore Dominance Types are the caddisfly Hydropsyche and the fingernail clam Pisidium.

\section{Unconsolidated Shore}

Definition. The Class Unconsolidated Shore includes all wetland habitats having three characteristics: (1) unconsolidated substrates with less than $75 \%$ areal cover of stones, boulders, or bedrock; (2) less than $30 \%$ areal cover of vegetation other than pioneering plants; and (3) any of the following water regimes: irregularly exposed, regularly flooded, irregularly flooded, seasonally flooded, temporarily flooded, intermittently flooded, saturated, or artificially flooded. Intermittent or intertidal channels of the Riverine System and intertidal channels of the Estuarine System are classified as Streambed.

Description. Unconsolidated Shores are characterized by substrates lacking vegetation except for pioneering plants that become established during brief periods when growing conditions are favorable. Erosion and deposition by waves and currents produce a number of landforms such as beaches, bars, and flats, all of which are included in this Class. Unconsolidated Shores are found adjacent to Unconsolidated Bottoms in all Systems; in the Palustrine and Lacustrine Systems, the Class may occupy the entire basin. As in Unconsolidated Bottoms, the particle size of the substrate and the water regime are the important factors determining the types of plant and animal communities present. Different substrates usually support characteristic invertebrate fauna. Faunal distribution is controlled by waves, currents, interstitial moisture, salinity, and grain size (Hedgpeth 1957; Ranwell 1972; Riedl and McMahan 1974).

Subclasses and Dominance Types.

Cobble-Gravel.-The unconsolidated particles smaller than stones are predominantly cobble and gravel. Shell fragments, sand, and silt often fill the spaces between the larger particles. Stones and boulders may be found scattered on some Cobble-Gravel Shores. In areas of strong wave and current action these shores take the form of beaches or bars, but occasionally they form extensive flats. Examples of Dominance Types in the Marine and Estuarine Systems are: the acorn barnacle Balanus, the limpet Patella, the periwinkle Littorina, the rock shell Thais, the mussels Mytilus and Modiolus, and the Venus clam Saxidomus. In the Lacustrine, Palustrine, and Riverine Systems examples of Dominance Types are the freshwater mollusk Elliptio, the snails Lymnaea and Physa, the toad bug Gelastocoris, the leech Erpodella, and the springtail Agrenia.

Sand.-The unconsolidated particles smaller than stones are predominantly sand which may be either calcareous or terrigenous in origin. They are prominent features of the Marine, Estuarine, Riverine, and Lacustrine Systems where the substrate material is exposed to the sorting and washing action of waves. Examples of Dominance Types in the Marine and Estuarine Systems are the wedge shell Donax, the soft-shell clam Mya, the quahog Mercenaria, the olive shell Oliva, the blood worm Euzonus, the beach hopper Orchestia, the pismo clam Tivela stultorum, the mole crab Emerita, and the lugworm Arenicola. Examples of Dominance Types in the Riverine, Lacustrine, and Palustrine Systems are the copepods Parastenocaris and Phyllognathopus, the oligochaete worm Pristina, the freshwater mollusks Anodonta and Elliptio, and the fingernail clams Pisidium and Sphaerium.

Mud.-The unconsolidated particles smaller than stones are predominantly silt and clay. Anaerobic conditions often exist below the surface. Mud Shores have a higher organic content than Cobble-Gravel or Sand Shores. They are typically found in areas of minor wave action. They tend to have little slope and are frequently called flats. Mud Shores support diverse populations of tube-dwelling and burrowing invertebrates that include worms, clams, and crustaceans (Gray 1974). They are com- 
monly colonized by algae and diatoms which may form a crust or mat.

Irregularly flooded Mud Shores in the Estuarine System have been called salt flats, pans, or pannes. They are typically high in salinity and are usually surrounded by, or lie on the landward side of, Emergent Wetland (Martin et al. 1953, Type 15). In many arid areas, Palustrine and Lacustrine Mud Shores are encrusted or saturated with salt. Martin et al. (1953) called these habitats inland saline flats (Type 9); they are also called alkali flats, salt flats, and salt pans. Mud Shores may also result from removal of vegetation by man, animals, or fire, or from the discharge of thermal waters or pollutants.

Examples of Dominance Types in the Marine and Estuarine Systems include the fiddler crab $U c a$, the ghost shrimp Callianassa, the mud snails Nassarius and Macoma, the clam worm Nereis, the sea anemone Cerianthus, and the sea cucumber Thyone. In the Lacustrine, Palustrine, and Riverine Systems, examples of Dominance Types are the fingernail clam Pisidium, the snails Aplexa and Lymnaea, the crayfish Procambarus, the harpacticoid copepods Canthocamptus and Bryocamptus, the fingernail clam Sphaerium, the freshwater mollusk Elliptio, the shore bug Saldula, the isopod Asellus, the crayfish Cambarus, and the mayfly Tortopus.

Organic.-The unconsolidated material smaller than stones is predominantly organic soils of formerly vegetated wetlands. In the Marine and Estuarine Systems, Organic Shores are often dominated by microinvertebrates such as foraminifera, and by Nassarius, Littorina, Uca, Modiolus, Mya, Nereis, and the false angel wing Petricola pholadiformis. In the Lacustrine, Palustrine, and Riverine Systems, examples of Dominance Types are Canthocamptus, Bryocamptus, Chironomus, and the backswimmer Notonecta.

Vegetated.-Some nontidal shores are exposed for a sufficient period to be colonized by herbaceous annuals or seedling herbaceous perennials (pioneer plants). This vegetation, unlike that of Emergent Wetlands, is usually killed by rising water levels and may be gone before the beginning of the next growing season. Many of the pioneer species are not hydrophytes but are weedy mesophytes that cannot tolerate wet soil or flooding. Examples of Dominance Types in the Palustrine, Riverine, and Lacustrine Systems are cocklebur (Xanthium strumarium) and barnyard grass (Echinochloa crusgalli).

Dominance Types for Unconsolidated Shores in the Marine and Estuarine Systems were taken primarily from Smith (1964), Morris (1966), Abbott (1968), Ricketts and Calvin (1968), and Gosner (1971). Dominance Types for Unconsolidated Shores in the Lacustrine, Riverine, and Palustrine Systems were taken primarily from Stehr and Branson (1938), Kenk (1949), Ward and Whipple (1959), Cummins et al. (1964), Johnson (1970), Ingram (1971), Clarke (1973), and Hart and Fuller (1974).

\section{Moss-Lichen Wetland}

Definition. The Moss-Lichen Wetland Class includes areas where mosses or lichens cover substrates other than rock and where emergents, shrubs, or trees make up less than $30 \%$ of the areal cover. The only water regime is saturated.

Description. Mosses and lichens are important components of the flora in many wetlands, especially in the north, but these plants usually form a ground cover under a dominant layer of trees, shrubs, or emergents. In some instances higher plants are uncommon and mosses or lichens dominate the flora. Such Moss-Lichen Wetlands are not common, even in the northern United States where they occur most frequently.

\section{Subclasses and Dominance Types.}

Moss.-Moss Wetlands are most abundant in the far north. Areas covered with peat mosses (Sphagnum spp.) are usually called bogs (Golet and Larson 1974; Jeglum et al. 1974; Zoltai et al. 1975), whether Sphagnum or higher plants are dominant. In Alaska, Drepanocladus and the liverwort Chiloscyphus fragilis may dominate shallow pools with impermanent water; peat moss and other mosses (Campylium stellatum, Aulacomnium palustre, and Oncophorus wahlenbergii) are typical of wet soil in this region (Britton 1957; Drury 1962).

Lichen.-Lichen Wetlands are also a northern Subclass. Reindeer moss (Cladina rangiferina) forms the most important Dominance Type. Pollett and Bridgewater (1973) described areas with mosses and lichens as bogs or fens, the distinction being based on the availability of nutrients and the particular plant species present. The presence of Lichen Wetlands has been noted in the Hudson Bay Lowlands (Sjörs 1959) and in Ontario (Jeglum et al. 1974).

\section{Emergent Wetland}

Definition. The Emergent Wetland Class is characterized by erect, rooted, herbaceous hydrophytes, excluding mosses and lichens. This vegetation is present for most of the growing season in most years. These wetlands are usually dominated by perennial plants. All water regimes are included except subtidal and irregularly exposed.

Description. In areas with relatively stable climatic conditions, Emergent Wetlands maintain the same appearance year after year. In other areas, such as the prairies of the central United States, violent climatic fluctuations cause them to revert to an open water phase in some years (Stewart and Kantrud 1972). Emergent Wetlands are found throughout the United States and occur in all Systems except the Marine. Emergent Wetlands are known by many names, including marsh, meadow, fen, prairie pothole, and slough. Areas that are dominated by 
pioneer plants which become established during periods of low water are not Emergent Wetlands and should be classified as Vegetated Unconsolidated Shores or Vegetated Streambeds.

Subclasses and Dominance Types.

Persistent.-Persistent Emergent Wetlands are dominated by species that normally remain standing at least until the beginning of the next growing season. This Subclass is found only in the Estuarine and Palustrine Systems.

Persistent Emergent Wetlands dominated by saltmarsh cordgrass (Spartina alterniflora), saltmeadow cordgrass (S. patens), big cordgrass (S. cynosuroides), needlerush (Juncus roemerianus), narrow-leaved cattail (Typha angustifolia), and southern wild rice (Zizaniopsis miliacea) are major components of the Estuarine systems of the Atlantic and Gulf Coasts of the United States. On the Pacific Coast, common pickleweed (Salicornia virginica), sea blite (Suaeda californica), arrow grass (Triglochin maritimum), and California cordgrass (Spartina foliosa) are common dominants.

Palustrine Persistent Emergent Wetlands contain a vast array of grasslike plants such as cattails (Typha spp.), bulrushes (Scirpus spp.), saw grass (Cladium jamaicense), sedges (Carex spp.); and true grasses such as reed (Phragmites australis), manna grasses (Glyceria spp.), slough grass (Beckmannia syzigachne), and whitetop (Scolochloa festucacea). There is also a variety of broadleaved persistent emergents such as purple loosestrife (Lythrum salicaria), dock (Rumex mexicanus), waterwillow (Decodon verticillatus), and many species of smartweeds (Polygonum).

Nonpersistent.-Wetlands in this Subclass are dominated by plants which fall to the surface of the substrate or below the surface of the water at the end of the growing season so that, at certain seasons of the year, there is no obvious sign of emergent vegetation. For example, wild rice (Zizania aquatica) does not become apparent in the North Central States until midsummer and fall, when it may form dense emergent stands. Nonpersistent emergents also include species such as arrow arum (Peltandra virginica), pickerelweed (Pontederia cordata), and arrowheads (Sagittaria spp.). Movement of ice in Estuarine, Riverine, or Lacustrine Systems often removes all traces of emergent vegetation during the winter. Where this occurs, the area should be classified as Nonpersistent Emergent Wetland.

\section{Scrub-Shrub Wetland}

Definition. The Class Scrub-Shrub Wetland includes areas dominated by woody vegetation less than $6 \mathrm{~m}$ (20 feet) tall. The species include true shrubs, young trees, and trees or shrubs that are small or stunted because of environmental conditions. All water regimes except subtidal are included.
Description. Scrub-Shrub Wetlands may represent a successional stage leading to Forested Wetland, or they may be relatively stable communities. They occur only in the Estuarine and Palustrine Systems, but are one of the most widespread classes in the United States (Shaw and Fredine 1956). Scrub-Shrub Wetlands are known by many names, such as shrub swamp (Shaw and Fredine 1956), shrub carr (Curtis 1959), bog (Heinselman 1970), and pocosin (Kologiski 1977). For practical reasons we have also included forests composed of young trees less than $6 \mathrm{~m}$ tall.

Subclasses and Dominance Types.

Broad-leaved Deciduous. - In Estuarine System Wetlands the predominant deciduous and broad-leaved trees or shrubs are plants such as sea-myrtle (Baccharis halimifolia) and marsh elder (Iva frutescens). In the Palustrine System typical Dominance Types are alders (Alnus spp.), willows (Salix spp.), buttonbush (Cephalanthus occidentalis), red osier dogwood (Cornus stolonifera), honeycup (Zenobia pulverulenta), spirea (Spiraea douglasii), bog birch (Betula pumila), and young trees of species such as red maple (Acer rubrum) or black spruce (Picea mariana).

Needle-leaved Deciduous. -This Subclass, consisting of wetlands where trees or shrubs are predominantly deciduous and needle-leaved, is represented by young or stunted trees such as tamarack or bald cypress (Taxodium distichum).

Broad-leaved Evergreen. - In the Estuarine System, vast wetland acreages are dominated by mangroves (Rhizophora mangle, Languncularia racemosa, Conocarpus erectus, and Avicennia germinans) that are less than $6 \mathrm{~m}$ tall. In the Palustrine System, the broad-leaved evergreen species are typically found on organic soils. Northern representatives are labrador tea (Ledum groenlandicum), bog rosemary (Andromeda glaucophylla), bog laurel (Kalmia polifolia), and the semi-evergreen leatherleaf (Chamaedaphne calyculata). In the south, fetterbush (Lyonia lucida), coastal sweetbells (Leucothoe axillaris), inkberry (Ilex glabra), and the semi-evergreen black ti-ti (Cyrilla racemiflora) are characteristic broad-leaved evergreen species.

Needle-leaved Evergreen.-The dominant species in Needle-leaved Evergreen Wetlands are young or stunted trees such as black spruce or pond pine (Pinus serotina).

Dead.-Dead woody plants less than $6 \mathrm{~m}$ tall dominate Dead Scrub-Shrub Wetlands. These wetlands are usually produced by a prolonged rise in the water table resulting from impoundment of water by landslides, man, or beavers. Such wetlands may also result from various other factors such as fire, salt spray, insect infestation, air pollution, and herbicides.

\section{Forested Wetland}

Definition. The Class Forested Wetland is characterized by woody vegetation that is $6 \mathrm{~m}$ tall or taller. All water regimes are included except subtidal. 
Description. Forested Wetlands are most common in the eastern United States and in those sections of the West where moisture is relatively abundant, particularly along rivers and in the mountains. They occur only in the Palustrine and Estuarine Systems and normally possess an overstory of trees, an understory of young trees or shrubs, and a herbaceous layer. Forested Wetlands in the Estuarine System, which include the mangrove forests of Florida, Puerto Rico, and the Virgin Islands, are known by such names as swamps, hammocks, heads, and bottoms. These names often occur in combination with species names or plant associations such as cedar swamp or bottomland hardwoods.

Subclasses and Dominance Types.

Broad-leaved Deciduous. - Dominant trees typical of Broad-leaved Deciduous Wetlands, which are represented throughout the United States, are most common in the South and East. Common dominants are species such as red maple, American elm (Ulmus americana), ashes (Fraxinus pennsylvanica and $F$. nigra), black gum (Nyssa sylvatica), tupelo gum ( $N$. aquatica), swamp white oak (Quercus bicolor), overcup oak (Q. lyrata), and basket oak (Q. michauxii). Wetlands in this subclass generally occur on mineral soils or highly decomposed organic soils.

Needle-leaved Deciduous. - The southern representative of the Needle-leaved Deciduous Subclass is bald cypress (Taxodium distichum), which is noted for its ability to tolerate long periods of surface inundation. Tamarack is characteristic of the Boreal Forest Region, where it occurs as a dominant on organic soils. Relatively few other species are included in this Subclass.

Broad-leaved Evergreen.-In the Southeast, Broadleaved Evergreen Wetlands reach their greatest development. Red bay (Persea borbonia), loblolly bay (Gordonia lasianthus), and sweet bay (Magnolia virginiana) are prevalent, especially on organic soils. This Subclass also includes red mangrove, black mangrove (Avicennia germinans), and white mangrove (Languncularia racemosa), which are adapted to varying levels of salinity.

Needle-leaved Evergreen.-Black spruce, growing on organic soils, represents a major dominant of the Needleleaved Evergreen Subclass in the North. Though black spruce is common on nutrient-poor soils, Northern white cedar (Thuja occidentalis) dominates northern wetlands on more nutrient-rich sites. Along the Atlantic Coast, Atlantic white cedar (Chamaecyparis thyoides) is one of the most common dominants on organic soils. Pond pine is a common needle-leaved evergreen found in the Southeast in association with dense stands of broad-leaved evergreen and deciduous shrubs.

Dead.-Dead Forested Wetlands are dominated by dead woody vegetation taller than $6 \mathrm{~m}$ (20 feet). Like Dead Scrub-Shrub Wetlands, they are most common in, or around the edges of, man-made impoundments and beaver ponds. The same factors that produce Dead Scrub-Shrub Wetlands produce Dead Forested Wetlands.

\section{Modifiers}

To fully describe wetlands and deepwater habitats, one must apply certain Modifiers at the Class level and at lower levels in the classification hierarchy. The Modifiers described below were adapted from existing classifications or were developed specifically for this system.

\section{Water Regime Modifiers}

Precise description of hydrologic characteristics requires detailed knowledge of the duration and timing of surface inundation, both yearly and long-term, as well as an understanding of groundwater fluctuations. Because such information is seldom available, the water regimes that, in part, determine characteristic wetland and deepwater plant and animal communities are described here in only general terms. Water regimes are grouped under two major headings, Tidal and Nontidal.

Tidal Water Regime Modifiers are used for wetlands and deepwater habitats in the Estuarine and Marine Systems and Nontidal Modifiers are used for all nontidal parts of the Palustrine, Lacustrine, and Riverine Systems. The Tidal Subsystem of the Riverine System and tidally influenced parts of the Palustrine and Lacustrine Systems require careful selection of Water Regime Modifiers. We designate subtidal and irregularly exposed wetlands and deepwater habitats in the Palustrine, Riverine, and Lacustrine Systems as permanently flooded-tidal rather than subtidal, and Palustrine, Riverine, and Lacustrine wetlands regularly flooded by the tide as regularly flooded. If Palustrine, Riverine, and Lacustrine wetlands are only irregularly flooded by tides, we designate them by the appropriate nontidal Water Regime Modifier with the word tidal added, as in seasonally flooded-tidal.

\section{Tidal}

The water regimes are largely determined by oceanic tides.

Subtidal. The substrate is permanently flooded with tidal water.

Irregularly Exposed. The land surface is exposed by tides less often than daily.

Regularly Flooded. Tidal water alternately floods and exposes the land surface at least once daily.

Irregularly Flooded. Tidal water floods the land surface less often than daily.

The periodicity and amplitude of tides vary in different parts of the United States, mainly because of differences in latitude and geomorphology. On the Atlantic Coast, two nearly equal high tides are the rule (semidiurnal). On the Gulf Coast, there is frequently only one high tide and one low tide each day (diurnal); and on the Pacific Coast there 
are usually two unequal high tides and two unequal low tides (mixed semidiurnal).

Individual tides range in height from about $9.5 \mathrm{~m} \mathrm{(31}$ feet) at St. John, New Brunswick (U.S. National Oceanic and Atmospheric Administration 1973) to less than $1 \mathrm{~m}$ (3.3 feet) along the Louisiana coast (Chabreck 1972). Tides of only $10 \mathrm{~cm}$ (4.0 inches) are not uncommon in Louisiana. Therefore, though no hard and fast rules apply, the division between regularly flooded and irregularly flooded water regimes would probably occur approximately at mean high water on the Atlantic Coast, lowest level of the higher high tide on the Pacific Coast, and just above mean tide level of the Gulf Coast. The width of the intertidal zone is determined by the tidal range, the slope of the shoreline, and the degree of exposure of the site to wind and waves.

\section{Nontidal}

Though not influenced by oceanic tides, nontidal water regimes may be affected by wind or seiches in lakes. Water regimes are defined in terms of the growing season, which we equate to the frost-free period (see the U.S. Department of Interior National Atlas 1970:110-111 for generalized regional delineation). The rest of the year is defined as the dormant season, a time when even extended periods of flooding may have little influence on the development of plant communities.

Permanently Flooded. Water covers the land surface throughout the year in all years. Vegetation is composed of obligate hydrophytes.

Intermittently Exposed. Surface water is present throughout the year except in years of extreme drought.

Semipermanently Flooded. Surface water persists throughout the growing season in most years. When surface water is absent, the water table is usually at or very near the land surface.

Seasonally Flooded. Surface water is present for extended periods especially early in the growing season, but is absent by the end of the season in most years. When surface water is absent, the water table is often near the land surface.

Saturated. The substrate is saturated to the surface for extended periods during the growing season, but surface water is seldom present.

Temporarily Flooded. Surface water is present for brief periods during the growing season, but the water table usually lies well below the soil surface for most of the season. Plants that grow both in uplands and wetlands are characteristic of the temporarily flooded regime.

Intermittently Flooded. The substrate is usually exposed, but surface water is present for variable periods without detectable seasonal periodicity. Weeks, months, or even years may intervene between periods of inunda tion. The dominant plant communities under this regime may change as soil moisture conditions change. Some areas exhibiting this regime do not fall within our definition of wetland because they do not have hydric soils or support hydrophytes.

Artificially Flooded. The amount and duration of flooding is controlled by means of pumps or siphons in combination with dikes or dams. The vegetation growing on these areas cannot be considered a reliable indicator of water regime. Examples of artificially flooded wetlands are some agricultural lands managed under a rice-soybean rotation, and wildlife management areas where forests, crops, or pioneer plants may be flooded or dewatered to attract wetland wildlife. Neither wetlands within or resulting from leakage from man-made impoundments, nor irrigated pasture lands supplied by diversion ditches or artesian wells, are included under this modifier.

\section{Water Chemistry Modifiers}

The accurate characterization of water chemistry in wetlands and deepwater habitats is difficult, both because of problems in measurement and because values tend to vary with changes in the season, weather, time of day, and other factors. Yet, very subtle changes in water chemistry, which occur over short distances, may have a marked influence on the types of plants or animals that inhabit an area. A description of water chemistry, therefore, must be an essential part of this classification system.

The two key characteristics employed in this system are salinity and hydrogen-ion concentration $(\mathrm{pH})$. All habitats are classified according to salinity, and freshwater habitats are further subdivided by $\mathrm{pH}$ levels.

\section{Salinity Modifiers}

Differences in salinity are reflected in the species composition of plants and animals. Many authors have suggested using biological changes as the basis for subdividing the salinity range between sea water and fresh water (Remane and Schlieper 1971). Others have suggested a similar subdivision for salinity in inland wetlands (Moyle 1946; Bayly 1967; Stewart and Kantrud 1971). Since the gradation between fresh and hypersaline or hyperhaline waters is continuous, any boundary is artificial, and few classification systems agree completely.

Estuarine and Marine waters are a complex solution of salts, dominated by sodium chloride $(\mathrm{NaCl})$. The term haline is used to indicate the dominance of ocean salt. The relative proportions of the various major ions are usually similar to those found in sea water, even if the water is diluted below sea water strength. Dilution of sea water with fresh water and concentration of sea water by evaporation result in a wide range of recorded salinities in both surface water and interstitial (soil) water. 
We have modified the Venice System, suggested at a "Symposium on the Classification of Brackish Waters" in 1958, for use in the Marine and Estuarine Systems (Table 2). The System has been widely used during recent years (Macan 1961, 1963; Burbank 1967; Carriker 1967; Reid and Wood 1976), although there has been some criticism of its applicability (den Hartog 1960; Price and Gunter 1964).

The salinity of inland water is dominated by four major cations, calcium $(\mathrm{Ca})$, magnesium $(\mathrm{Mg})$, sodium $(\mathrm{Na})$, and potassium $(\mathrm{K})$; and three major anions, carbonate $\left(\mathrm{CO}_{3}\right)$, sulfate $\left(\mathrm{SO}_{4}\right)$, and chloride (Cl) (Wetzel 1975). Salinity is governed by the interactions between precipitation, surface runoff, groundwater flow, evaporation, and sometimes evapotranspiration by plants. The ionic ratios of inland waters usually differ appreciably from those in the sea, although there are exceptions (Bayly 1967). The great chemical diversity of these waters, the wide variation in physical conditions such as temperature, and often the relative impermanence of surface water, make it extremely difficult to subdivide the inland salinity range in a meaningful way. Bayly (1967) attempted a subdivision on the basis of animal life; Moyle (1945) and Stewart and Kantrud (1971) have suggested two very different divisions on the basis of plant life. We employ a subdivision that is identical to that used in the Estuarine and Marine Systems (Table 2).

The term saline is used to indicate that any of a number of ions may be dominant or codominant. The term brackish has been applied to inland waters of intermediate salinity (Remane and Schlieper 1971; Stewart and Kantrud 1971), but is not universally accepted (see Bayly 1967:84); therefore, mixosaline is used here. In some inland wetlands, high soil salinities control the invasion or establishment of many plants. These salinities are expressed in units of specific conductance as well as percent salt (Ungar 1974) and they are also covered by the salinity classes in Table 2.

\section{$\mathrm{pH}$ Modifiers}

Acid waters are, almost by definition, poor in calcium and often generally low in other ions, but some very soft waters may have a neutral $\mathrm{pH}$ (Hynes 1970). It is difficult to separate the effects of high concentrations of hydrogen ions from low base content, and many studies suggest that acidity may never be the major factor controlling the presence or absence of particular plants and animals. Nevertheless, some researchers have demonstrated a good correlation between $\mathrm{pH}$ levels and plant distribution (Sjörs 1950; Jeglum 1971). Jeglum (1971) showed that plants can be used to predict the $\mathrm{pH}$ of moist peat.

There seems to be little doubt that, where a peat layer isolates plant roots from the underlying mineral substrate, the availability of minerals in the root zone strongly influences the types of plants that occupy the site. For this reason, many authors subdivide freshwater, organic wet- lands into mineral-rich and mineral-poor categories (Sjörs 1950; Heinselman 1970; Jeglum 1971; Moore and Bellamy 1974). We have instituted $\mathrm{pH}$ modifiers for freshwater wetlands (Table 3 ) because $\mathrm{pH}$ has been widely used to indicate the difference between mineral-rich and mineralpoor sites, and because it is relatively easy to determine. The ranges presented here are similar to those of Jeglum (1971), except that the upper limit of the circumneutral level (Jeglum's mesotrophic) was raised to bring it into agreement with usage of the term in the United States. The ranges given apply to the $\mathrm{pH}$ of water. They were converted from Jeglum's moist-peat equivalents by adding $0.5 \mathrm{pH}$ units.

\section{Soil Modifiers}

Soil is one of the most important physical components of wetlands. Through its depth, mineral composition, organic matter content, moisture regime, temperature regime, and chemistry, it exercises a strong influence over the types of plants that live on its surface and the kinds of organisms that dwell within it. In addition, the nature of soil in a wetland, particularly the thickness of organic soil, is of critical importance to engineers planning construction of highways or buildings. For these and other reasons, it is essential that soil be considered in the classification of wetlands.

According to the U.S. Soil Conservation Service, Soil Survey Staff (1975:1-2), soil is limited to terrestrial situations and shallow waters; however, "areas are not considered to have soil if the surface is permanently covered by water deep enough that only floating plants are present...." Since emergent plants do not grow beyond a depth of about $2 \mathrm{~m}$ in inland waters, the waterward limit of soil is virtually equivalent to the waterward limit of wetland, according to our definition. Wetlands can then be regarded as having soil in most cases, whereas deepwater habitats are never considered to have soil.

The most basic distinction in soil classification in the United States is between mineral soil and organic soil (U.S. Soil Conservation Service, Soil Survey Staff 1975). The Soil Conservation Service recognizes nine orders of mineral soils and one order of organic soils (Histosols) in its taxonomy. Their classification is hierarchical and permits the description of soils at several levels of detail. For example, suborders of Histosols are recognized according to the degree of decomposition of the organic matter.

Table 3. $p H$ Modifiers used in this classification system.

\begin{tabular}{lr}
\hline Modifier & $\mathrm{pH}$ of Water \\
\hline Acid & $<5.5$ \\
Circumneutral & $5.5-7.4$ \\
Alkaline & $>7.4$ \\
\hline
\end{tabular}


We use the Modifiers mineral and organic in this classification. Mineral soils and organic soils are differentiated on the basis of specific criteria that are enumerated in soil taxonomy (U.S. Soil Conservation Service, Soil Survey Staff 1975:13-14, 65). These criteria are restated in our Appendix $\mathrm{D}$ for ready reference. If a more detailed classification is desired, the U.S. Soil Conservation Service classification system should be used.

\section{Special Modifiers}

Many wetlands and deepwater habitats are man-made, and natural ones have been modified to some degree by the activities of man or beavers. Since the nature of these modifications often greatly influences the character of such habitats, special modifying terms have been included here to emphasize their importance. The following Modifiers should be used singly or in combination wherever they apply to wetlands and deepwater habitats.

\section{Excavated}

Lies within a basin or channel excavated by man.

Impounded

Created or modified by a barrier or dam which purposefully or unintentionally obstructs the outflow of water. Both man-made dams and beaver dams are included.

\section{Diked}

Created or modified by a man-made barrier or dike designed to obstruct the inflow of water.

\section{Partly Drained}

The water level has been artificially lowered, but the area is still classified as wetland because soil moisture is sufficient to support hydrophytes. Drained areas are not considered wetland if they can no longer support hydrophytes.

\section{Farmed}

The soil surface has been mechanically or physically altered for production of crops, but hydrophytes will become reestablished if farming is discontinued.

\section{Artificial}

Refers to substrates classified as Rock Bottom, Unconsolidated Bottom, Rocky Shore, and Unconsolidated Shore that were emplaced by man, using either natural materials such as dredge spoil or synthetic materials such as discarded automobiles, tires, or concrete. Jetties and breakwaters are examples of Artificial Rocky Shores. Man-made reefs are an example of Artificial Rock Bottoms.

\section{REGIONALIZATION FOR THE CLASSIFICATION SYSTEM}

In this classification system, a given taxon has no particular regional alliance; its representatives may be found in one or many parts of the United States. However, regional variations in climate, geology, soils, and vegetation are important in the development of different wetland habitats; and management problems often differ greatly in different regions. For these reasons, there is a need to recognize regional differences. Regionalization is designed to facilitate three activities: (1) planning, where it is necessary to study management problems and potential solutions on a regional basis; (2) organization and retrieval of data gathered in a resource inventory; and (3) interpretation of inventory data, including differences in indicator plants and animals among the regions.

We recommend the classification and map (Fig. 7) of Bailey (1976) to fill the need for regionalization inland. Bailey's classification of ecoregions is hierarchical. The upper four levels are domain (defined as including subcontinental areas of related climates), division (defined as including regional climate at the level of Köppen's [1931] types), province (defined as including broad vegetational types), and section (defined as including climax vegetation at the level of Küchler's [1964] types). On the map, the boundaries between the different levels are designated by lines of various widths and the sections are numbered with a four-digit code; digits 1 through 4 represent the first four levels in the hierarchy. The reader is referred to Bailey $(1976,1978)$ for detailed discussion and description of the units appearing on his map, reproduced in our Fig. 7.

The Bailey system terminates at the ocean, whereas the present wetland classification includes Marine and Estuarine habitats. Many workers have divided Marine and Estuarine realms into series of biogeographic provinces (e.g., U.S. Senate 1970; Ketchum 1972). These provinces differ somewhat in detail, but the broader concepts are similar. Figure 7 shows the distribution of 10 Marine and Estuarine provinces that we offer for North America.

- Arctic Province extends from the southern tip of Newfoundland (Avalon Peninsula), northward around Canada to the west coasts of the Arctic Ocean, Bering Sea, and Baffin and Labrador basins. It is characterized by the southern extension of floating ice, the $4{ }^{\circ} \mathrm{C}$ summer isotherm, and Arctic biota.

- Acadian Province extends along the Northeast Atlantic Coast from the Avalon Peninsula to Cape Cod and is characterized by a well developed algal flora and boreal biota. The shoreline is heavily indented and frequently rocky. It has a large tidal range and is strongly influenced by the Labrador Current.

- Virginian Province extends along the Middle Atlantic Coast from Cape Cod to Cape Hatteras. The province 


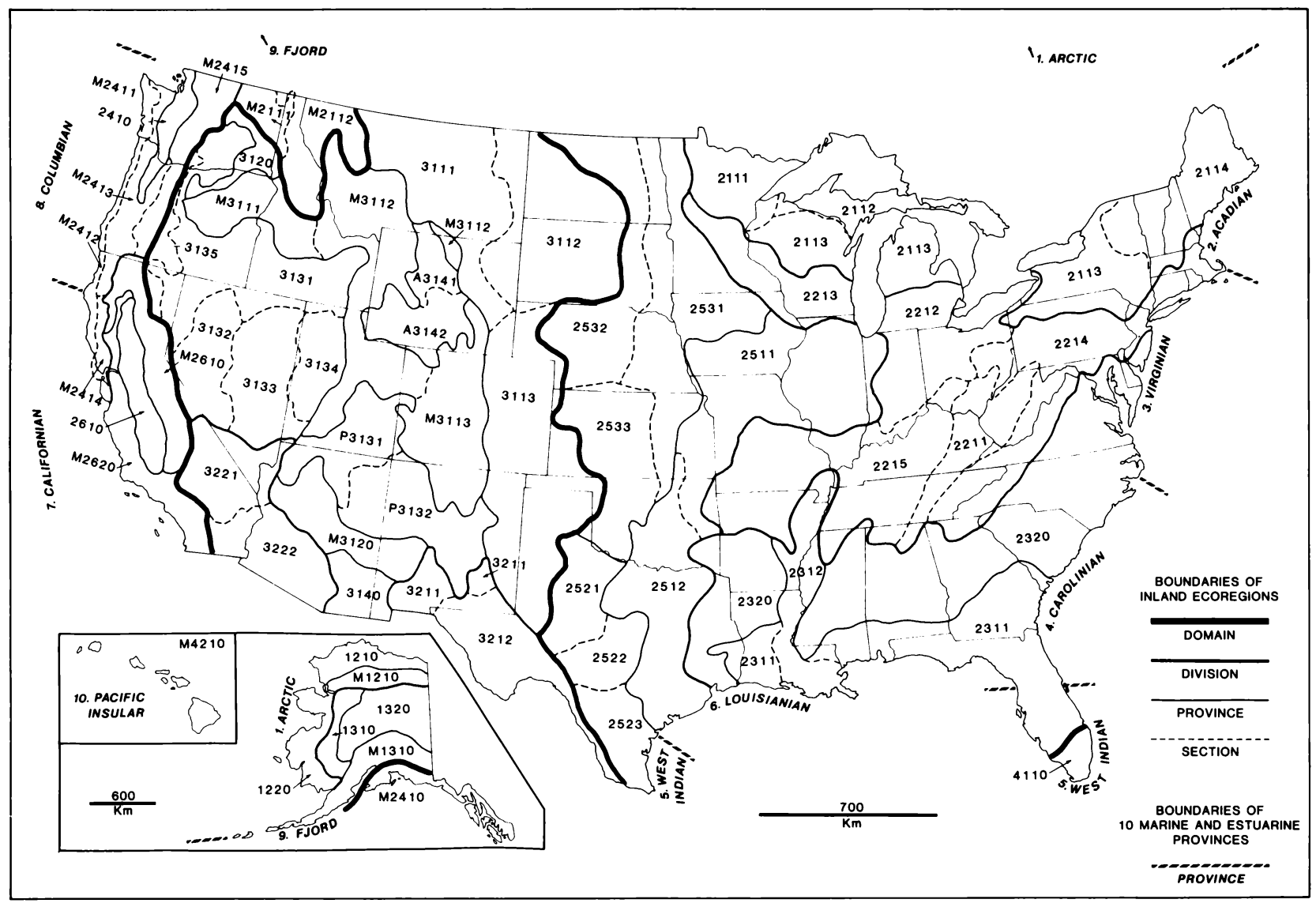

Fig. 7. Ecoregions of the United States after Bailey (1976) with the addition of 10 Marine and Estuarine Provinces proposed in our classification.

aDomains, Divisions, Provinces, and Sections used on Bailey's (1976) map and described in detail in Bailey (1978). Highland ecoregions are designated $\mathrm{M}$ mountain, $\mathrm{P}$ plateau, and $\mathrm{A}$ altiplano.

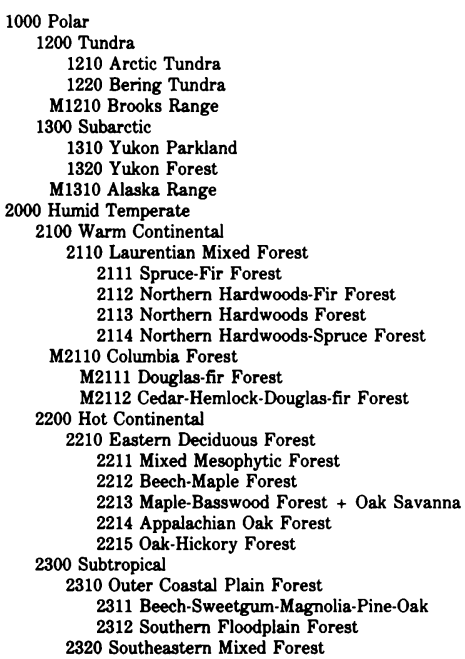

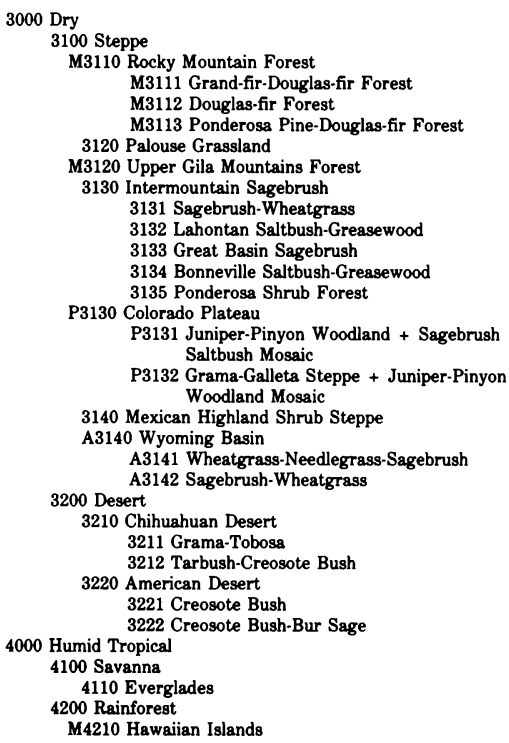


is transitional between the Acadian and Carolinian Provinces. The biota is primarily temperate, but has some boreal representatives. The Labrador Current occasionally extends down to Cape Hatteras and winter temperatures may approach $4^{\circ} \mathrm{C}$. The tidal range is moderate.

- Carolinian Province is situated along the South Atlantic Coast from Cape Hatteras to Cape Kennedy. It contains extensive marshes and well developed barrier islands. Waters are turbid and productive. The biota is temperate but has seasonal tropical elements. The Gulf Stream is the primary influence, and winter temperatures reach a minimum of $10^{\circ} \mathrm{C}$; summer temperatures are tropical (in excess of $20^{\circ} \mathrm{C}$ ). The tidal range is small to moderate.

- West Indian Province extends from Cape Kennedy to Cedar Key, Florida, and also includes the southern Gulf of Mexico, the Yucatan Peninsula, Central America, and the Caribbean Islands. The shoreland is usually low-lying limestone with calcareous sands and marls, except for volcanic islands. The biota is tropical and includes reef corals and mangroves. Minimum winter temperatures are about $20^{\circ} \mathrm{C}$ and the tidal range is small.

- Louisianian Province extends along the northern coast of the Gulf of Mexico from Cedar Key to Port Aransas, Texas. The characteristics of the province are similar to those of the Carolinian, reflecting the past submergence of the Florida Peninsula. The biota is primarily temperate and the tidal range is small.

- Californian Province extends along the Pacific Coast from Mexico northward to Cape Mendocino. The shoreland is strongly influenced by coastal mountains and the coasts are rocky. Freshwater runoff is limited. In the southern part volcanic sands are present; marshes and swamps are scarce throughout the province. The climate is Mediterranean and is influenced by the California Current. The biota is temperate, and includes well developed offshore kelp beds. The tidal range is moderate.

- Columbian Province extends along the northern Pacific Coast from Cape Mendocino to Vancouver Island. Mountainous shorelands with rocky foreshores are prevalent. Estuaries are strongly influenced by freshwater runoff. The biota is primarily temperate with some boreal components, and there are extensive algal communities. The province is influenced by both the Aleutian and California Currents. The tidal range is moderate to large.

- Fjord Province extends along the Pacific Coast from Vancouver Island to the southern tip of the Aleutian Islands. Precipitous mountains, deep estuaries (some with glaciers), and a heavily indented shoreline subject to winter icing are typical of the coast. The biota is boreal to subArctic. The province is influenced by the Aleutian and Japanese Currents, and the tidal range is large.

- Pacific Insular Province surrounds all the Hawaiian Islands. The coasts have precipitous mountains and wave action is stronger than in most of the other provinces. The biota is largely endemic and composed of tropical and subtropical forms. The tidal range is small.

Use of Bailey's sections for the Riverine, Lacustrine, and Palustrine Systems and the Provinces defined above for the Marine and Estuarine Systems provides a regional locator for any wetland in the United States.

\section{USE OF THE CLASSIFICATION SYSTEM}

This System was designed for use over an extremely wide geographic area and for use by individuals and organizations with varied interests and objectives. The classification employs 5 System names, 8 Subsystem names, 11 Class names, 28 Subclass names, and an unspecified number of Dominance Types. It is, of necessity, a complex System when viewed in its entirety, but use of the System for a specific purpose at a local site should be simple and straightforward. Artificial keys to the Systems and Classes (Appendix E) are furnished to aid the user of the classification, but reference to detailed definitions in the text is also required. The purpose of this section is to illustrate how the System should be used and some of the potential pitfalls that could lead to its misuse.

Before attempting to apply the System, the user should consider four important points:

(1) Information about the area to be classified must be available before the System can be applied. This information may be in the form of historical data, aerial photographs, brief on-site inspection, or detailed and intensive studies. The System is designed for use at varying degrees of detail. There are few areas for which sufficient information is available to allow the most detailed application of the System. If the level of detail provided by the data is not sufficient for the needs of the user, additional data gathering is mandatory.

(2) Below the level of Class, the System is open-ended and incomplete. We give only examples of the vast number of Dominance Types that occur. The user may identify additional Dominance Types and determine where these fit into the classification hierarchy. It is also probable that as the System is used the need for additional Subclasses will become apparent.

(3) One of the main purposes of the new classification is to ensure uniformity throughout the United States. It is important that the user pay particular attention to the definitions in the classification. Any attempt at modification of these definitions will lead to lack of uniformity in application.

(4) One of the principal uses of the classification system will be the inventory and mapping of wetlands and deepwater habitats. A classification used in the mapping is scale-specific, both for the minimum size of units mapped 
and for the degree of detail attainable. It is necessary for the user to develop a specific set of mapping conventions for each application and to demonstrate their relationship to the generalized classification described here. For example, there are a number of possible mapping conventions for a small wetland basin $50 \mathrm{~m}$ (164 feet) in diameter with concentric rings of vegetation about the deepest zone. At a scale of 1:500 each zone may be classified and mapped; at 1:20,000 it might be necessary to map the entire basin as one zone and ignore the peripheral bands; and at 1:100,000 the entire wetland basin may be smaller than the smallest mappable unit, and such a small-scale map is seldom adequate for a detailed inventory and must be supplemented by information gathered by sampling. In other areas, it may be necessary to develop mapping conventions for taxa that cannot be easily recognized; for instance, Aquatic Beds in turbid waters may have to be mapped simply as Unconsolidated Bottom.

\section{Hierarchical Levels and Modifiers}

We have designed the various levels of the system for specific purposes, and the relative importance of each will vary among users. The Systems and Subsystems are most important in applications involving large regions or the entire country. They serve to organize the Classes into meaningful assemblages of information for data storage and retrieval.

The Classes and Subclasses are the most important part of the system for many users and are basic to wetland mapping. Most Classes should be easily recognizable by users in a wide variety of disciplines. However, the Class designations apply to average conditions over a period of years, and since many wetlands are dynamic and subject to rapid changes in appearance, the proper classification of a wetland will frequently require data that span a period of years and several seasons in each of those years.

The Dominance Type is most important to users interested in detailed regional studies. It may be necessary to identify Dominance Types in order to determine which modifying terms are appropriate, because plants and animals present in an area tend to reflect environmental conditions over a period of time. Water regime can be determined from long-term hydrologic studies where these are available. The more common procedure will be to estimate this characteristic from the Dominance Types. Several studies have related water regimes to the presence and distribution of plants or animals (e.g., Stephenson and Stephenson 1972; Stewart and Kantrud 1972; Chapman 1974).

Similarly, we do not intend that salinity measurements be made for all wetlands except where these data are required; often plant species or associations can be used to indicate broad salinity classes. Lists of halophytes have been prepared for both coastal and inland areas (e.g.,
Duncan 1974; MacDonald and Barbour 1974; Ungar 1974), and a number of floristic and ecological studies have described plants that are indicators of salinity (e.g., Penfound and Hathaway 1938; Moyle 1945; Kurz and Wagner 1957; Dillon 1966; Anderson et al. 1968; Chabreck 1972; Stewart and Kantrud 1972; Ungar 1974).

In areas where the Dominance Types to be expected under different water regimes and types of water chemistry conditions have not been identified, detailed regional studies will be required before the classification can be applied in detail. In areas where detailed soil maps are available, it is also possible to infer water regime and water chemistry from soil series (U.S. Soil Conservation Service, Soil Survey Staff 1975).

Some of the Modifiers are an integral part of this system and their use is essential; others are used only for detailed applications or for special cases. Modifiers are never used with Systems and Subsystems; however, at least one Water Regime Modifier, one Water Chemistry Modifier, and one Soil Modifier must be used at all lower levels in the hierarchy. Use of the Modifiers listed under mixosaline and mixohaline (Table 2) is optional but these finer categories should be used whenever supporting data are available. The user is urged not to rely on single observations of water regime or water chemistry. Such measurements give misleading results in all but the most stable wetlands. If a more detailed Soil Modifier, such as soil order or suborder (U.S. Soil Conservation Service, Soil Survey Staff 1975) can be obtained, it should be used in place of the Modifiers, mineral and organic. Special Modifiers are used where appropriate.

\section{Relationship to Other Wetland Classifications}

There are numerous wetland classifications in use in the United States. Here we relate this system to three published classifications that have gained widespread acceptance. It is not possible to equate these systems directly for several reasons: (1) the criteria selected for establishing categories differ; (2) some of the classifications are not applied consistently in different parts of the country; and (3) the elements classified are not the same in various classifications.

The most widely used classification system in the United States is that of Martin et al. (1953) which was republished in U.S. Fish and Wildlife Service Circular 39 (Shaw and Fredine 1956). The wetland types are based on criteria such as water depth and permanence, water chemistry, life form of vegetation, and dominant plant species. In Table 4 we compare some of the major components of our system with the type descriptions listed in Circular 39.

In response to the need for more detailed wetland classification in the glaciated Northeast, Golet and Larson (1974) refined the freshwater wetland types of 
Table 4. Comparison of wetland types described in U.S. Fish and Wildlife Service Circular 39 with some of the major components of this classification system.

Circular 39 type and references for examples of typical vegetation

Classification of wetlands and deepwater habitats

Classes

Type 1-Seasonally flooded basins or flats

Wet meadow (Dix and Smeins 1967; Stewart and Kantrud 1972)

Bottomland hardwoods (Braun 1950)

Shallow-freshwater swamps (Penfound 1952)

$\begin{array}{lll}\text { Emergent Wetland } & \text { Temporarily Flooded } & \text { Fresh } \\ \text { Forested Wetland } & \begin{array}{c}\text { Intermittently } \\ \text { Flooded }\end{array} & \text { Mixosaline }\end{array}$

Type 2-Inland fresh meadows

Fen (Heinselman 1963)

Fen, northern sedge meadow (Curtis 1959)

Emergent Wetland Saturated

Fresh

Type 3-Inland shallow fresh marshes

Shallow marsh (Stewart and Kantrud 1972; Golet and Larson 1974)

Type 4-Inland deep fresh marshes

Deep marsh (Stewart and Kantrud 1972; Golet and Larson 1974)

Type 5-Inland open fresh water

Open water (Golet and Larson 1974)

Submerged aquatic (Curtis 1959)

Type 6-Shrub swamps

Shrub swamp (Golet and Larson 1974)

Shrub-carr, alder thicket (Curtis 1959)

Type 7-Wooded swamps

Wooded swamp (Golet and Larson 1974)

Swamps (Penfound 1952; Heinselman 1963)

Type 8-Bogs

Bog (Dansereau and Segadas-vianna 1952; Heinselman 1963)

Pocosin (Penfound 1952; Kologiski 1977)

Type 9-Inland saline flats

Intermittent alkali zone (Stewart and Kantrud 1972)

Type 10-Inland saline marshes

Inland salt marshes (Ungar 1974)

Type 11-Inland open saline water

Inland saline lake community (Ungar 1974)

Type 12-Coastal shallow fresh marshes

Marsh (Anderson et al. 1968)

Estuarine bay marshes, estuarine river marshes (Stewart 1962)

Fresh and intermediate marshes (Chabreck 1972)

Water

chemistry

Water regimes

Mixosaline

Emergent Wetland Semipermanently Fresh

Flooded

Seasonally Flooded

Emergent Wetland Permanently Flooded

Aquatic Bed

Aquatic Bed

Unconsolidated

Bottom

Mixosaline

Scrub-Shrub

Wetland

Forested Wetland

Scrub-Shrub
Wetland
Forested Wetland
Moss-Lichen
Wetland
Unconsolidated
Shore

Emergent Wetland

Unconsolidated
Bottom

Emergent Wetland
Intermittently

Exposed

Semipermanently

Flooded

Permanently Flooded

Intermittently

Exposed

All nontidal regimes except Permanently Flooded

All nontidal regimes except Permanently Flooded

Saturated

Seasonally Flooded Temporarily Flooded Intermittently

Flooded

Semipermanently

Flooded

Seasonally Flooded

Permanently Flooded Intermittently

Exposed

Fresh

Mixosaline

Fresh

Mixosaline

Fresh

Fresh

Fresh (acid only)

Eusaline

Hypersaline

Eusaline

Regularly Flooded Irregularly Flooded Semipermanently

Flooded-Tidal
Mixohaline

Fresh 
Table 4. Continued.

Circular 39 type and references for examples of vegetation

Classification of wetlands and deepwater habitats

\begin{tabular}{|c|c|c|c|}
\hline & Classes & Water regimes & $\begin{array}{l}\text { Water } \\
\text { chemistry }\end{array}$ \\
\hline \multicolumn{4}{|l|}{ Type 13-Coastal deep fresh marshes } \\
\hline Marsh (Anderson et al. 1968) & Emergent Wetland & Regularly Flooded & Mixohaline \\
\hline $\begin{array}{l}\text { Estuarine bay marshes, estuarine river marshes } \\
\text { (Stewart 1962) }\end{array}$ & & $\begin{array}{l}\text { Semipermanently } \\
\text { Flooded-Tidal }\end{array}$ & Fresh \\
\hline \multicolumn{4}{|l|}{ Fresh and intermediate marshes (Chabreck 1972) } \\
\hline \multicolumn{4}{|l|}{ Type 14-Coastal open fresh water } \\
\hline \multirow[t]{2}{*}{ Estuarine bays (Stewart 1962) } & Aquatic Bed & Subtidal & Mixohaline \\
\hline & $\begin{array}{l}\text { Unconsolidated } \\
\text { Bottom }\end{array}$ & $\begin{array}{l}\text { Permanently } \\
\text { Flooded-Tidal }\end{array}$ & Fresh \\
\hline \multicolumn{4}{|l|}{ Type 15-Coastal salt flats } \\
\hline Panne, slough marsh (Redfield 1972) & Unconsolidated & Regularly Flooded & Hyperhaline \\
\hline Marsh pans (Pestrong 1965) & Shore & Irregularly Flooded & Euhaline \\
\hline \multicolumn{4}{|l|}{ Type 16-Coastal salt meadows } \\
\hline Salt marsh (Redfield 1972; Chapman 1974) & Emergent Wetland & Irregularly Flooded & $\begin{array}{l}\text { Euhaline } \\
\text { Mixohaline }\end{array}$ \\
\hline \multicolumn{4}{|l|}{ Type 17-Irregularly flooded salt marshes } \\
\hline Salt marsh (Chapman 1974) & Emergent Wetland & Irregularly Flooded & Euhaline \\
\hline Saline, brackish, and intermediate marsh (Eleuterius 1972) & & & Mixohaline \\
\hline \multicolumn{4}{|l|}{ Type 18-Regularly flooded salt marshes } \\
\hline Salt marsh (Chapman 1974) & Emergent Wetland & Regularly Flooded & $\begin{array}{l}\text { Euhaline } \\
\text { Mixohaline }\end{array}$ \\
\hline \multicolumn{4}{|l|}{ Type 19-Sounds and bays } \\
\hline Kelp beds, temperate grass flats (Phillips 1974) & Unconsolidated & Subtidal & Euhaline \\
\hline Tropical marine meadows (Odum 1974) & Bottom & Irregularly Exposed & Mixohaline \\
\hline \multirow[t]{2}{*}{ Eelgrass beds (Akins and Jefferson 1973; Eleuterius 1973) } & Aquatic Bed & Regularly Flooded & \\
\hline & $\begin{array}{l}\text { Unconsolidated } \\
\text { Shore }\end{array}$ & Irregularly Flooded & \\
\hline \multicolumn{4}{|l|}{ Type 20-Mangrove swamps } \\
\hline Mangrove swamps (Walsh 1974) & Scrub-Shrub & Irregularly Exposed & Hyperhaline \\
\hline Mangrove swamp systems (Kuenzler 1974) & Wetland & Regularly Flooded & Euhaline \\
\hline Mangrove (Chapman 1976) & Forested Wetland & Irregularly Flooded & $\begin{array}{l}\text { Mixohaline } \\
\text { Fresh }\end{array}$ \\
\hline
\end{tabular}

Circular 39 by writing more detailed descriptions and subdividing classes on the basis of finer differences in plant life forms. Golet and Larson's classes are roughly equivalent to Types 1-8 of Circular 39, except that they restrict Type 1 to river floodplains. The Golet and Larson system does not recognize the coastal (tidal) fresh wetlands of Circular 39 (Types 12-14) as a separate category, but classifies these areas in the same manner as nontidal wetlands. In addition to devising 24 subclasses, they also created 5 size categories, 6 site types giving a wetland's hydrologic and topographic location; 8 cover types (modified from Stewart and Kantrud 1971) expressing the distribution and relative proportions of cover and water; 3 vegetative interspersion types; and 6 surrounding habitat types. Since this system is based on the classes of Martin et al. (1953), Table 4 may also be used to compare the Golet and Larson system with the one described here. Although our system does not include size categories and site types, this information will be available from the results of the new inventory of wetlands and deepwater habitats of the United States.

Stewart and Kantrud (1971) devised a new classification system to better serve the needs of researchers and wetland managers in the glaciated prairies. Their system recognizes seven classes of wetlands which are distinguished by the vegetational zone occupying the central or deepest part and covering 5\% or more of the wetland basin. The classes thus reflect the wetland's water regime; for example, temporary ponds (Class II) are those where the wet-meadow zone occupies the deepest part of the wetland. Six possible subclasses were created, based on differences in plant species composition that are correlated with variations in average salinity of surface water. The third component of classification in their system is the 
cover type, which represents differences in the spatial relation of emergent cover to open water or exposed bottom soil. The zones of Stewart and Kantrud's system are readily related to our water regime modifiers (Table 5), and the subclasses are roughly equivalent to our Water Chemistry Modifiers (Fig. 8).

Wetlands represent only one type of land and the classification of this part separate from the rest is done for practical rather than for ecological reasons (Cowardin 1978). Recently there has been a flurry of interest in a holistic approach to land classification (in Land Classification Series, Journal of Forestry, vol. 46, no. 10). A number of classifications have been developed (e.g., Radford 1978) or are under development (e.g., Driscoll et al. 1978). Parts
Table 5. Comparison of the zones of Stewart and Kantrud's (1971) classification with the Water Regime Modifiers used in the present classification system.

\begin{tabular}{ll}
\hline \multicolumn{1}{c}{ Zone } & \multicolumn{1}{c}{ Water Regime Modifier } \\
\hline Wetland-low-prairie & $\begin{array}{l}\text { Non-wetland by our definition } \\
\text { Temporarily flooded }\end{array}$ \\
Wet meadow & $\begin{array}{l}\text { Seasonally flooded } \\
\text { Shallow marsh }\end{array}$ \\
Deep marsh & $\begin{array}{l}\text { Semipermanently flooded } \\
\text { Intermittently exposed }\end{array}$ \\
Intermittent-alkali & $\begin{array}{l}\text { Intermittently flooded (with eusaline } \\
\text { or hypersaline water) }\end{array}$ \\
Permanent-open- & $\begin{array}{l}\text { Permanently flooded (with mixo- } \\
\text { hater }\end{array}$ \\
Fen (alkaline water)
\end{tabular}

\section{APPROXIMATE \\ SPECIFIC \\ STEWART AND KANTRUD \\ (1972)}

( $\mu$ Mhos)

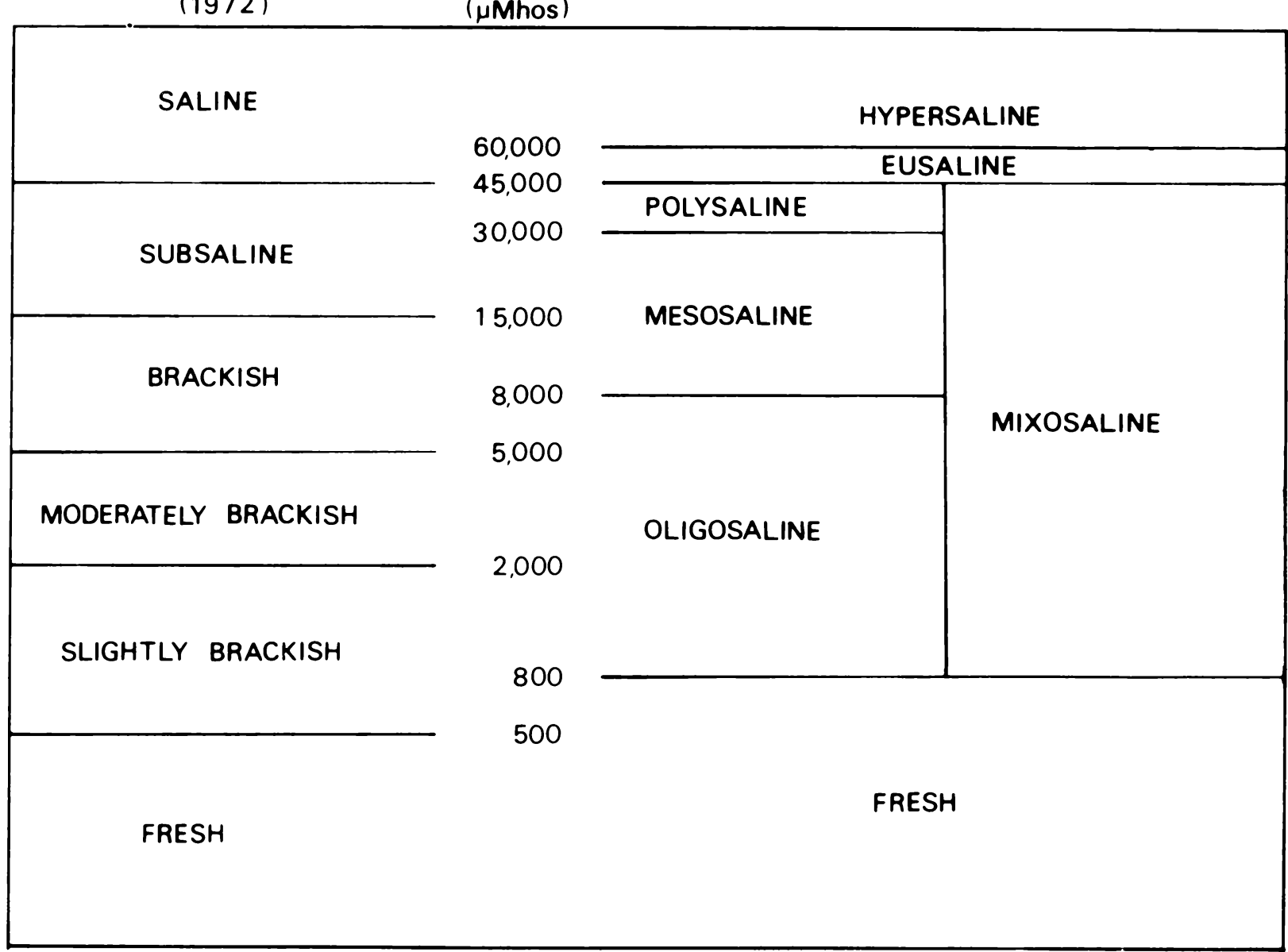

Fig. 8. Comparison of the water chemistry subclasses of Stewart and Kantrud (1972) with Water Chemistry Modifiers used in the present classification system. 
of this wetland classification can be incorporated into broader hierarchical land classifications.

A classification system is most easily learned through use. To illustrate the application of this system, we have classified a representative group of wetlands and deepwater habitats of the United States (Plates 1-86; pages 46-131).

\section{ACKNOWLEDGMENTS}

The breadth and complexity of preparing this classification caused us to solicit help and advice from individuals too numerous to list here. Frequently the recommendations were in conflict and we take responsibility for the decisions we have made but acknowledge all suggestions including those not accepted. Several meetings were crucial in formulating the present classification and in modifying earlier drafts. We thank those who attended the formative meeting at Bay St. Louis, Mississippi, January 1975; The National Wetland Classification and Inventory Workshop at College Park, Maryland, July 1975; and the review panels assembled at Sapelo Island, Georgia, and at St. Petersburg, Florida. We also thank those individuals and agencies who responded to distribution of the operational draft. Special credit is due the regional coordinators of the National Wetlands Inventory and P. B. Reed, who have furnished continuing consultation on application of the system. Martel Laboratories field-tested the system and furnished specific criticisms. We were advised by J. Everett on geomorphology, K. K. Young and O. Carter on soil taxonomy, R. P. Novitzki on hydrology, and R. H. Chabreck on coastal wetland ecology. M. L. Heinselman and R. H. Hofstetter helped with difficult problems of peatland ecology and terminology. R. L. Kologiski aided with botanical problems. J. H. Montanari, W. O. Wilen, and the entire National Wetlands Inventory staff furnished encouragement and logistic support. The staff of the Northern Prairie Wildlife Research Center contributed substantially to completion of the classification. Art work and graphics were prepared by J. Rodiek, R. L. Duval, and C. S. Shaiffer. J. H. Sather worked closely with us and served as editor on previous drafts.

\section{REFERENCES}

Abbott, R. T. 1968. Seashells of North America. Golden Press, New York. 280 pp.

Akins, G. J., and C. Q. Jefferson. 1973. Coastal wetlands of Oregon. Oregon Coastal Conservation and Development Commission, Florence, Oregon. 159 pp.

Anderson, J. R., E. E. Hardy, J. T. Roach, and R. E. Witmer. 1976. A land use and land cover classification system for use with remote sensor data. U.S. Geol. Surv. Prof. Pap. 964. 28 pp.

Anderson, R. R., R. G. Brown, and R. D. Rappleye. 1968. Water quality and plant distribution along the upper Patuxent River, Maryland. Chesapeake Sci. 9:145-156.
Bailey, R. G. 1976. Ecoregions of the United States, U.S. Forest Service, Ogden, Utah. (Map only; scale 1:7,500,000.)

Bailey, R. G. 1978. Ecoregions of the United States. U.S. Forest Service, Intermountain Region, Ogden, Utah. 77 pp.

Bayly, I. A. E. 1967. The general biological classification of aquatic environments with special reference to those of Australia. Pages 78-104 in A. H. Weatherley, ed. Australian inland waters and their fauna. Australian National University Press, Canberra.

Black, C. A. 1968. Soil plant relationships. John Wiley \& Sons, Inc., New York. 792 pp.

Bormann, F. H., and G. E. Likens, 1969. The watershed-ecosystem concept and studies of nutrient cycles. Pages 49-76 in G. M. VanDyne, ed. The ecosystem concept in natural resource management. Academic Press, New York.

Braun, E. L. 1950. Deciduous forests of eastern North America. Hafner Publishing Co., New York and London. 596 pp.

Brinkhurst, R. O., and B. G. M. Jamieson. 1972. Aquatic oligochaetes of the world. University of Toronto Press, Toronto. 860 pp.

Britton, M. E. 1957. Vegetation of the Arctic tundra. Oregon State Univ. Biol. Colloq. 18:26-61.

Burbank, W. D. 1967. Evolutionary and ecological implications of the zoogeography, physiology and morphology of Cyanthura (Isopoda). Pages 564-573 in G. H. Lauff, ed. Estuaries. Am. Assoc. Adv. Sci. Publ. 83.

Cain, S. A., and G. M. de Oliveira Castro. 1959. Manual of vegetation analysis. Harper \& Brothers, New York. 325 pp.

Carriker, M. R. 1967. Ecology of estuarine benthic invertebrates: a perspective. Pages 442-487 in G. H. Lauff, ed. Estuaries. Am Assoc. Adv. Sci. Publ. 83.

Caspers, H. 1967. Estuaries: analysis of definitions and biılogical considerations. Pages 6-8 in G. H. Lauff, ed. Estuaries. Am. Assoc. Adv. Sci. Publ. 83.

Chabreck, R. H. 1972. Vegetation, water and soil characteristics of the Louisiana coastal region. La. Agric. Exp. Stn. Bull. 664. $72 \mathrm{pp}$.

Chapman, V. J. 1974. Salt marshes and salt deserts of the world. 2nd supplemented edition. J. Cramer, Lehre. 392 pp

Chapman, V. J. 1976. Mangrove vegetation. J. Cramer, Leuterhausen. 447 pp.

Chapman, V. J. 1977. Introduction. Pages 1-30 in V. J. Chapman, ed. Wet coastal ecosystems. Ecosystems of the world 1. Elsevier Scientific Publishing Co., New York.

Clarke, A. H. 1973. The freshwater mollusks of the Canadian Interior Basin. Malacologia 13(1-2):1-509.

Cowardin, L. M. 1978. Wetland classification in the United States. J. For. 76(10):666-668.

Crickmay, C. H. 1974. The work of the river. The MacMillan Press, Ltd., London. $271 \mathrm{pp}$.

Cummins, K. W., C. A. Tryon, Jr., and R. T. Hartman, editors. 1964. Organism-substrate relationships in streams. Pymatuning Lab. Ecol., Univ. Pittsburg Spec. Publ. 4. 145 pp.

Curtis, J. T. 1959. The vegetation of Wisconsin. The University of Wisconsin Press, Madison. 657 pp.

Dansereau, P., and F. Segadas-vianna. 1952. Ecological study of the peat bogs of eastern North America. I. Structure and evolution of vegetation. Can. J. Bot. 30:490-520.

Daubenmire, R. 1968. Plant communities. Harper \& Row, New York. 300 pp. 
den Hartog, C. 1960. Comments on the Venice-system for the classification of brackish water. Int. Rev. gesamten Hydrobiol. 45:481-485.

Dillon, O. W. 1966. Gulf coast marsh handbook. U.S. Soil Conservation Service, Alexandria, Louisiana. n.p.

Dix. R. L., and F. E. Smeins. 1967. The prairie, meadow, and marsh vegetation of Nelson County, North Dakota. Can. J. Bot. 45:21-58.

Driscoll, R. S., J. W. Russell, and M. C. Meier. 1978. Recommended national land classification system for renewable resource assessments. U.S. Forest Service, Rocky Mountain Forest and Range Experiment Station, Fort Collins, Colorado. (Unpublished manuscript)

Drury, W. H., Jr. 1962. Patterned ground and vegetation on southern Bylot Island, Northwest Territories, Canada. Harvard Univ. Gray Herb. Contrib. 190. 111 pp.

Duncan, W. H. 1974. Vascular halophytes of the Atlantic and Gulf coasts of North America north of Mexico. Pages 23-50 in R. J. Reimold and W. H. Queen, eds. Ecology of halophytes. Academic Press, Inc., New York.

Eleuterius, L. M. 1972. The marshes of Mississippi. Castanea 37:153-168.

Eleuterius, L. M. 1973. The distribution of certain submerged plants in Mississippi Sound and adjacent waters. Pages 191-197 in J. L. Christmas, ed. Cooperative Gulf of Mexico estuarine inventory and study. Mississippi Gulf Coast Research Laboratory, Ocean Springs.

Golet, F. C., and J. S. Larson. 1974. Classification of freshwater wetlands in the glaciated Northeast. U.S. Fish Wildl. Serv., Resour. Publ. 116. 56 pp.

Gosner, K. L. 1971. Guide to identification of marine and estuarine invertebrates: Cape Hatteras to the Bay of Fundy. John Wiley \& Sons, Inc., New York. 693 pp.

Gray, I. E. 1974. Worm and clam flats. Pages 204-243 in H. T. Odum, B. J. Copeland, and E. A. McMahan, eds. Coastal ecological systems of the United States. Vol. 2. The Conservation Foundation, Washington, D.C.

Hart, C. W., Jr., and S. L. H. Fuller, editors. 1974. Pollution ecology of freshwater invertebrates. Academic Press, Inc., New York. $389 \mathrm{pp}$.

Hedgpeth, J. W. 1957. Classification of marine environments. Pages 17-28 in J. W. Hedgpeth, ed. Treatise on marine ecology and paleoecology; Vol. 1-Ecology. Geol. Soc. Am. Mem. 67.

Heinselman, M. L. 1963. Forest sites, bog processes, and peatland types in the Glacial Lake Agassiz Region, Minnesota. Ecol. Monogr. 33(4):327-374.

Heinselman, M. L. 1970. Landscape evolution, peatland types, and the environment in the Lake Agassiz Peatlands Natural Area, Minnesota, Ecol. Monogr. 40(2):235-261.

Hutchinson, G. E. 1975. A treatise on limnology. Vol. 3. Limnological botany. John Wiley \& Sons, New York. 660 pp.

Hynes, H. B. N. 1970. The ecology of running waters. University of Toronto Press, Toronto. $555 \mathrm{pp}$.

Illies, J., and L. Botosaneau. 1963. Problems et methodes de la classification et de la zonation ecologique des aux courantes, considerees surtout du point de vue faunistique. Int. Assoc. Theor. Appl. Limnol. Commun. 12. 57 pp.

Ingram, W. M. 1971. Survival of fresh-water mollusks during periods of dryness. Nautilis 54(3):84-87.

Jeglum, J. K. 1971. Plant indicators of $\mathrm{pH}$ and water level in peatlands at Candle Lake, Saskatchewan. Can. J. Bot. 49:16611676.
Jeglum, J. K., A. N. Boissonneau, and V. G. Haavisto. 1974. Toward a wetland classification for Ontario. Can. For. Serv. Inf. Rep. O-X-215. 54 pp.

Johnson, R. I. 1970. The systematics and zoogeography of the Unionidae (Mollusca: Bivalvia) of the Southern Atlantic Slope Region. Harvard Univ. Mus. Comp. Zool. Bull. 140(6):263-450.

Kenk, R. 1949. The animal life of temporary and permanent ponds in southern Michigan. Univ. Mich. Mus. Zool. Misc. Publ. 71. $66 \mathrm{pp}$.

Ketchum, B. H., editor. 1972. The water's edge: critical problems of the coastal zone. MIT Press, Cambridge, Mass. 393 pp.

Kologiski, R. L. 1977. The phytosociology of the Green Swamp, North Carolina. N.C. Agric. Exp. Stn. Tech. Bull. 250. 101 pp. Köppen, W. 1931. Grundriss der Klimakunde. Walter de Gruyter \& Co., Berlin. 388 pp.

Krecker, F. H., and L. Y. Lancaster. 1933. Bottom shore fauna of western Lake Erie: a population study to a depth of six feet. Ecology 14:79-83.

Küchler, A. W. 1964. Potential natural vegetation of the conterminous United States. Am. Geogr. Soc. Spec. Publ. 36. 116 pp.

Kuenzler, E. J. 1974. Mangrove swamp systems. Pages 346-371 in H. T. Odum, B. J. Copeland, and E. A. McMahan, eds. Coastal ecological systems of the United States. Vol. 1. The Conservation Foundation, Washington, D.C.

Kurz, H., and K. Wagner. 1957. Tidal marshes of the Gulf and Atlantic coasts of northern Florida and Charleston, South Carolina. Fla. State Univ. Stud. 24. 168 pp.

Langbein, W. B., and K. T. Iseri. 1960. General introduction and hydrologic definitions manual of hydrology. Part 1. General surface-water techniques. U.S. Geol. Surv. Water-Supply Pap. 1541-A. 29 pp.

Lauff, G. H., editor. 1967. Estuaries. Am. Assoc. Adv. Sci. Publ. 83.

Leitch, W. G. 1966. Historical and ecological factors in wetland inventory. Trans. N. Am. Wildl. Nat. Resour. Conf. 31:88-96.

Lewis, J. R. 1964. The ecology of rocky shores. English Universities Press Ltd., London. $323 \mathrm{pp}$.

Liu, T. K. 1970. A review of engineering soil classification systems. Pages 362-382 in Special procedures for testing soil and rock for engineering purposes. Am. Soc. Test. Mater. Spec. Tech. Publ. 479. 630 pp.

Macan, T. T. 1961. Factors that limit the range of freshwater animals. Biol. Rev. 36:151-198.

Macan, T. T. 1963. Freshwater ecology. John Wiley \& Sons. Inc., New York. 338 pp.

MacDonald, K. B., and M. B. Barbour. 1974. Beach and salt marsh vegetation of the North American Pacific coast. Pages 175-233 in R. J. Reimold and W. H. Queen, eds. Ecology of halophytes. Academic Press, Inc., New York.

Martin, A. C., N. Hotchkiss, F. M. Uhler, and W. S Bourn. 1953. Classification of wetlands of the United States. U.S. Fish Wildl. Serv., Spec. Sci. Rep.-Wildl. 20. 14 pp.

Millar, J. B. 1976. Wetland classification in western Canada: a guide to marshes and shallow open water wetlands in the grasslands and parklands of the Prairie Provinces. Can. Wildl. Serv. Rep. Ser. 37. 38 pp.

Miner, R. W. 1950. Field book of seashore life. G. P. Putnam's Sons, New York. 888 pp.

Montanari, J. H., and J. E. Townsend. 1977. Status of the National Wetlands Inventory. Trans. N. Am. Wildl. Nat. Resour. Conf. 42:66-72. 
Moore, P. D., and D. J. Bellamy. 1974. Peatlands. SpringerVerlag, Inc., New York. 221 pp.

Morris, P. A. 1966. A field guide to shells of the Pacific Coast and Hawaii. Houghton Mifflin Company, Boston. $297 \mathrm{pp}$.

Moyle, J. B. 1945. Some chemical factors influencing the distribution of aquatic plants in Minnesota. Am. Midl. Nat. 34(2):402420.

Moyle, J. B. 1946. Some indices of lake productivity. Trans. Am. Fish. Soc. 76:322-334.

Mueller-Dombois, D., and H. Ellenberg. 1974. Aims and methods of vegetation ecology. John Wiley \& Sons, New York. 547 pp.

Odum, E. P. 1971. Fundamentals of ecology. W. B. Saunders Co., Philadelphia. 544 pp.

Odum, H. T. 1974. Tropical marine meadows. Pages 442-487 in H. T. Odum, B. J. Copeland, and E. A. McMahan, eds. Coastal ecological systems of the United States. Vol. 1. The Conservation Foundation, Washington, D.C.

Odum, H. T., B. J. Copeland, and E. A. McMahan, editors. 1974. Coastal ecological systems of the United States. The Conservation Foundation, Washington, D.C. 4 Vol.

Penfound, W. T. 1952. Southern swamps and marshes. Bot. Rev. 18:413-436.

Penfound, W. T., and E. S. Hathaway. 1938. Plant communities in the marshlands of southeastern Louisiana. Ecol. Monogr. 8:1-56.

Pennak, R. W. 1978. Fresh-water invertebrates of the United States. 2nd Edition. John Wiley \& Sons, New York. 803 pp.

Pestrong, R. 1965. The development of drainage patterns on tidal marshes. Stanford Univ. Publ. Geol. Sci. 10:1-87.

Phillips, R. C. 1974. Temperate grass flats. Pages 244-314 in H. T. Odum, B. J. Copeland, and E. A. McMahan, eds. Coastal ecological systems of the United States. Vol. 2. The Conservation Foundation, Washington, D.C.

Pollett, F. C., and P. B. Bridgewater. 1973. Phytosociology of peatlands in central Newfoundland. Can. J. For. Res. 3(3):433442.

Price, J. B., and G. Gunter. 1964. Studies of the chemistry of fresh and low salinity waters in Mississippi and the boundary between fresh and brackish water. Int. Rev. gesamten Hydrobiol. 49:629-636.

Radford, A. E. 1978. Natural area classification systems: a standardized scheme for basic inventory of species, community and habitat diversity. Pages 243-279 in Proceedings of the National Symposium, Classification, Inventory, and Analysis of Fish and Wildlife Habitat. U.S. Fish and Wildlife Service, Washington, D.C.

Radforth, N. W. 1962. Organic terrain and geomorphology. Can. Geogr. 6(3-4):166-171.

Ranwell, D. S. 1972. Ecology of salt marshes and sand dunes. Chapman and Hall, London. 258 pp.

Redfield, A. C. 1972. Development of a New England salt marsh. Ecol. Monogr. 42(2):201-237.

Reid, G. K., and R. D. Wood. 1976. Ecology of inland waters and estuaries. D. Van Nostrand and Co., New York. 485 pp.

Remane, A., and C. Schlieper. 1971. Biology of brackish water. Wiley Interscience Division, John Wiley \& Sons, New York. $372 \mathrm{pp}$.

Ricketts, E. F., and J. Calvin. 1968. Between Pacific tides, 4th ed. Revised by J. W. Hedgpeth. Stanford University Press, Stanford, California. 614 pp.

Riedl, R., and E. A. McMahan. 1974. High energy beaches. Pages 180-251 in H. T. Odum, B. J. Copeland, and E. A. McMahan, eds. Coastal ecological systems of the United States. Vol. 1. The Conservation Foundation, Washington, D.C.

Sculthorpe, C. D. 1967. The biology of aquatic vascular plants. Edward Arnold Ltd., London. 610 pp.

Shaw, S. P., and C. G. Fredine. 1956. Wetlands of the United States. U.S. Fish Wildl. Serv., Circ. 39. 67 pp.

Sjörs, H. 1950. On the relation between vegetation and electrolytes in north Swedish mire waters. Oikos 2:241-258.

Sjörs, H. 1959. Bogs and fens in the Hudson Bay lowlands. J. Arctic Inst. Am. 12(1):2-19.

Slack, K. V., J. W. Nauman, and L. J. Tilley. 1977. Benthic invertebrates in an arctic mountain stream, Brooks Range, Alaska. J. Res. U.S. Geol. Surv. 5:519-527.

Smith, R. I. 1964. Key to marine invertebrates of the Woods Hole Region. Contribution No. 11 of the Systematic-Ecology Program, Marine Biological Laboratory, Woods Hole, Massachusetts. $208 \mathrm{pp}$.

Stegman, J. L. 1976. Overview of current wetland classification and inventories in the United States and Canada: U.S. Fish and Wildlife Service. Pages 102-120 in J. H. Sather, ed. National wetland classification and inventory workshop proceedings -1975 , University of Maryland. U.S. Fish and Wildlife Service, Washington, D.C.

Stehr, W. C., and J. W. Branson. 1938. An ecological study of an intermittent stream. Ecology 19(1):294-354.

Stephenson, T. A., and A. Stephenson. 1972. Life between tidemarks on rocky shores. W. H. Freeman and Co., San Francisco. $425 \mathrm{pp}$.

Stewart, R. E. 1962. Waterfowl populations in the upper Chesapeake Region. U.S. Fish Wildl. Serv., Spec. Sci. Rep.-Wildl. 65. $208 \mathrm{pp}$.

Stewart, R. E., and H. A. Kantrud. 1971. Classification of natural ponds and lakes in the glaciated prairie region. U.S. Fish. Wildl. Serv., Resour. Publ. 92.57 pp.

Stewart, R. E., and H. A. Kantrud. 1972. Vegetation of prairie potholes, North Dakota, in relation to quality of water and other environmental factors. U.S. Geol. Surv. Prof. Pap. 585-D. 36 pp.

Thorson, G. 1957. Bottom communities. Pages 461-534 in J. W. Hedgpeth, ed. Treatise on marine ecology and paleoecology. Geol. Soc. Am. Mem. 67. Vol. 1.

Ungar, I. A. 1974. Inland halophytes of the United States. Pages 235-305 in R. J. Reimold and W. H. Queen, eds. Ecology of halophytes. Academic Press, New York. 605 pp.

U.S. Department of Agriculture. 1982. National list of scientific plant names. Vol. 1, List of plant names; Vol. 2, Synonymy. U.S. Soil Conservation Service, SCS-TP-159, Washington, D.C. Vol. 1-416pp., Vol. 2-438 pp.

U.S. Department of Interior. 1970. National atlas of the United States. U.S. Geological Survey, Washington, D.C. 417 pp.

U.S. National Oceanic and Atmospheric Administration. 1973. Tide tables-high and low predictions 1974: East coast of North and South America. U.S. Government Printing Office, Washington, D.C. 288 pp.

U.S. Senate. 1970. The National Estuarine Pollution Study. Report of the Secretary of Interior to the United States Congress pursuant to Public Law 89-753, The Clean Water Restoration Act of 1966. U.S. Senate Doc. No. 91-58. U.S. Government Printing Office, Washington, D.C. 633 pp.

U.S. Soil Conservation Service, Soil Survey Staff. 1975. Soil Taxonomy: a basic system of soil classification for making and interpreting soil surveys. U.S. Soil Conservation Service. Agric. Handb. 436. 754 pp. 
van der Schalie, H. 1948. The land and freshwater mollusks of Puerto Rico. Univ. Mich. Mus. Zool. Misc. Publ. 70. 134 pp.

Walker, D. A. 1983. A hierarchical tundra vegetation classification especially designed for mapping in northern Alaska. Pages 1332-1337 in Permafrost: Fourth International Conference Proceedings, 17-22 July, 1983, University of Alaska, Fairbanks, Alaska. National Academy Press, Washington, D.C.

Walsh, G. E. 1974. Mangroves: a review. Pages 51-174 in R. J. Reimold and W. H. Queen, eds. Ecology of halophytes. Academic Press, Inc., New York.

Ward, H. B., and G. C. Whipple. 1959. Freshwater biology. John Wiley and Sons, Inc., New York. 1248 pp.

Ward, J. V. 1975. Bottom fauna-substrate relationships in a northern Colorado trout stream: 1945 and 1974. Ecology 56:14291434.

Weaver, J. E., and F. E. Clements. 1938. Plant ecology, 2nd ed. McGraw-Hill Book Company, Inc., New York. 601 pp.
Weber, C. I., editor. 1973. Biological field and laboratory methods for measuring the quality of surface waters and effluents. U.S. Environmental Protection Agency, Office of Research and Development, Environmental Monitoring Series. EPA 670/473-001.

Welch, P. S. 1952. Limnology, 2nd ed. McGraw-Hill, New Yark. $538 \mathrm{pp}$.

Wetzel, R. G. 1975. Limnology. W. B. Saunders Co., Philadelphia. $658 \mathrm{pp}$.

Zhadin, V. I., and S. V. Gerd. 1963. Fauna and flora of the rivers, lakes and reservoirs of the U.S.S.R. Oldbourne Press, London. $626 \mathrm{pp}$.

Zoltai, S. C., F. C. Pollett, J. K. Jeglum, and G. D. Adams. 1975. Developing a wetland classification for Canada. Proc. N. Am. For. Soils Conf. 4:497-511. 


\section{APPENDIX A}

\section{Scientific and Common Names \\ of Plants}

Scientific name ${ }^{\mathrm{a}}$

Acer rubrum L.

Alisma plantago-aquatica $\mathrm{L}$.

Alnus spp.

A. rugosa (DuRoi) Spreng.

A. tenuifolia Nutt.

Alopecurus aequalis Sobol.

Andromeda glaucophylla Link

Arctophila fulva (Trin.)

Anderss.

Aristida stricta Michx.

Ascophyllum spp.

A. nodosum (L.) LeJol.

Aulacomnium palustre

(Hedw.) Schwaegr.

Avicennia germinans (L.) L.

Azolla spp.

Baccharis halimifolia L.

Beckmannia syzigachne

(Steud.) Fernald

Betula nana L.

B. pumila L.

Brasenia schreberi

J. F. Gmel.

Calamagrostis canadensis

(Michx.) Beauv.

Calopogon spp.

Caltha palustris L.

Campylium stellatum (Hedw.)

C. Jens

Carex spp.

C. aquatilis Wahlenb.

C. atherodes Spreng.

C. bipartita All.

C. lacustris Willd.

C. lasiocarpa Ehrh.

C. lyngbyei Hornem.

C. paleacea Schreb. ex Wahlenb.

C. pluriflora Hulten

C. ramenskii Kom.

C. rariflora (Wahlenb.)

J. E. Smith

C. rostrata J. Stokes
Common name ${ }^{b}$

Red maple

(Water plantain)

Alders

Speckled alder

Thinleaf alder

Foxtail

Bog rosemary

Pendent grass

(Three-awn)

(Rockweeds)

Knotted wrack

(Moss)

Black mangrove

Mosquito ferns

Sea-myrtle

Slough grass

Dwarf birch

Bog birch

Water shield

Bluejoint

Grass pinks

Marsh marigold

(Moss)

Sedges

(Sedge)

Slough sedge

(Sedge)

(Sedge)

(Sedge)

(Sedge)

(Sedge)

(Sedge)

(Sedge)

(Sedge)

Beaked sedge

aTaxonomy of vascular plants is according to the National List of Scientific Plant Names (U.S. Dept. Agriculture 1982).

${ }^{b}$ General common names that refer to a higher taxon and names for which there is little agreement are shown in parentheses.

Scientific name $^{\mathrm{a}}$

Cassiope tetragona (L.)

D. Don

Caulerpa spp.

Cephalanthus occidentalis L.

Ceratophyllum spp.

Chamaecyparis thyoides (L.) B.S.P.

Chamaedaphne calyculata (L.) Moench

Chara spp.

Chenopodium glaucum L.

Chiloscyphus fragilis (Roth) Schiffn.

Chondrus crispus Stackhouse

Cladina spp.

C. rangiferina (L.) Harm

Cladium jamaicense Crantz

Colocasia esculenta (L.) Scott

Conocarpus erectus L.

Cornus stolonifera Michx.

Cymodocea filiformis (Kuetz) Correll

Cyperus spp.

Cyrilla racemiflora $\mathrm{L}$.

Decodon verticillatus (L.)

Elliott

Dendranthema arcticum (L.)

Tzvel.

Dermatocarpon fluviatile

G. H. Web) Th. Fr.

Distichlis spicata (L.) Greene

Drepanocladus spp.

Dryas integrifolia Vahl

Echinochloa crusgalli (L.)

Beauv.

Eichhornia crassipes (Mart.)

Solms

Eleocharis sp.

E. palustris (L.) Roem. \&

J. A. Schultes

Elodea spp.

Elymus arenarius L.

Empetrum nigrum L.

Enteromorpha spp.

Eriophorum spp.

E. russeolum Fr.

E. vaginatum $\mathrm{L}$.

Fissidens spp.
Common name ${ }^{b}$

Lapland cassiope

(Green algae)

Buttonbush

Coontails

Atlantic white cedar

Leatherleaf

(Stoneworts)

(Goosefoot)

(Liverwort)

Irish moss

Reindeer mosses

(Reindeer moss)

Saw grass

Taro

Buttonwood

Red osier dogwood

Manatee grass

Nut sedges

Black ti-ti

Water willow

Arctic daisy

(Lichen)

(Salt grass)

(Moss)

(Dryas)

Barnyard grass

Water hyacinth

(Spike rush)

(Spike rush)

Water weeds

(Lyme grass)

Crowberry

(Green algae)

Cotton grasses

(Cotton grass)

(Cotton grass)

(Moss) 
Scientific name ${ }^{\mathrm{a}}$

$F$. julianus (Mont.) Schimper

Fontinalis spp.

Fraxinus nigra Marshall

$F$. pennsylvanica Marshall

Fucus spp.

F. spiralis L.

$F$. vesiculosus L.

Glyceria spp.

Gordonia lasianthus (L.)

J. Ellis

Habenaria spp.

Halimeda spp.

Halodule wrightii Aschers.

Halophila spp.

Hippuris tetraphylla L.f.

Hydrilla verticillata Royle

Ilex glabra (L.) Gray

I. verticillata (L.) Gray

Iva frutescens $\mathrm{L}$.

Juncus spp.

J. gerardii Loiseleur

$J$. militaris Bigel.

$J$. roemerianus Scheele

Kalmia angustifolia L.

$K$. polifolia Wangenh.

Kochia scoparia (L.) Schrad.

Languncularia racemosa (L.)

C. F. Gaertn.

Laminaria spp.

Larix laricina (DuRoi)

K. Koch

Laurencia spp.

Ledum decumbens (Ait.)

Small

L. groenlandicum Oeder

Lemna spp.

L. minor L.

Leucothoe axillaris (Lam.)

D. Don

Ligusticum scothicum L.

Lithothamnion spp.

Lycopodium alopecuroides L.

Lyonia lucida (Lam.) K. Koch

Lythrum salicaria L.

Macrocystis spp.

Magnolia virginiana L.

Marsupella spp.

M. emarginata (Ehrenberg)

Dumortier

Myrica gale L.

Myriophyllum spp.

M. spicatum L.

Najas spp.

Nelumbo lutea (Willd.) Pers.

Nitella spp.
Common name ${ }^{b}$

(Moss)

(Moss)

Black ash

(Red ash)

Rockweeds

(Rockweed)

(Rockweed)

Manna grasses

Loblolly bay

(Orchids)

(Green algae)

Shoal grass

(Sea grass)

(Mare's tail)

(Hydrilla)

Inkberry

Winterberry

Marsh elder

Rushes

Black grass

Bayonet rush

Needlerush

Sheep laurel

Bog laurel

Summer cypress

White mangrove

(Kelps)

Tamarack

(Red algae)

Narrowleaf Labrador tea

Labrador tea

(Duckweeds)

Common duckweed

Coastal sweetbells

Beach lovage

Coralline algae

Foxtail clubmoss

Fetterbush

Purple loosestrife

(Kelps)

Sweet bay

(Liverworts)

(Liverwort)

Sweet gale

Water milfoils

(Water milfoil)

Naiads

American lotus

(Stoneworts)
Scientific name ${ }^{\mathrm{a}}$

Nuphar luteum (L.) Sibth. \& J. E. Smith

Nymphaea spp.

$N$. odorata Soland. in Ait.

Nyssa aquatica L.

$N$. sylvatica Marshall

Oncophorus wahlenbergii Brid.

Panicum capillare L.

Pedicularis sp.

Peltandra virginica (L.) Kunth

Pelvetia spp.

Penicillus spp.

Persea borbonia (L.) Spreng.

Phragmites australis (Cav.)

Trin. ex Steud.

Phyllospadix scouleri Hook.

$P$. torreyi S. Wats.

Picea mariana (Mill.) B.S.P.

$P$. sitchensis (Bong.) Carriere

Pinus contorta Dougl. ex Loudon

$P$. palustris Mill.

$P$. serotina Michx.

Pistia stratiotes L.

Plantago maritima L.

Podostemum ceratophyllum Michx.

Polygonum spp.

$P$. amphibium L.

$P$. bistorta L.

Pontederia cordata L.

Potamogeton spp.

$P$. gramineus $\mathrm{L}$.

$P$. natans L.

Populus balsamifera L.

$P$. deltoides W. Bartram ex Marshall

Potentilla anserina L.

$P$. fruticosa $\mathrm{L}$.

$P$. palustris (L.) Scop.

Puccinellia grandis Swallen

Quercus bicolor Willd.

$Q$. lyrata Walter

Q. michauxii Nutt.

Ranunculus pallasii Schlecht.

$R$. trichophyllus D. Chaix

Rhizophora mangle L.

Rhododendron maximum $\mathrm{L}$.

Rhynchospora spp.

Rubus chamaemorus L.

Rumex maritimus L.
Common name ${ }^{b}$

(Yellow water lily)

(Water lilies)

(White water lily)

Tupelo gum

Black gum

(Moss)

Old witch grass

(Lousewort)

Arrow arum

(Rockweeds)

(Green algae)

Red bay

Reed

(Surfgrass)

(Surfgrass)

Black spruce

Sitka spruce

Lodgepole pine

Longleaf pine

Pond pine

Water lettuce

Seaside plantain

Riverweed

Smartweeds

Water smartweed

Bistort

Pickerelweed

Pondweeds

(Pondweed)

Floating-leaf pondweed

Balsam poplar

Cottonwood

Silverweed

Shrubby cinquefoil

Marsh cinquefoil

(Alkali grass)

Swamp white oak

Overcup oak

Basket oak

(Crowfoot)

White water crowfoot

Red mangrove

Great laurel

Beak rushes

Cloudberry

Golden dock 
Scientific name ${ }^{\mathrm{a}}$

$R$. mexicanus Meisn.

Ruppia spp.

R. maritima L.

Sagittaria spp.

Salicornia spp.

S. europaea L.

S. virginica L.

Salix spp.

S. alaxensis (Anderss.) Coville

$S$. fuscescens Anderss.

S. ovalifolia Trautv.

S. planifolia Pursh

$S$. reticulata $\mathrm{L}$.

Salvinia spp.

Sarcobatus vermiculatus

(Hook.) Torr.

Scirpus spp.

$S$. acutus Muhl. ex Bigel.

S. americanus Pers.

S. robustus Pursh

Scolochloa festucacea

(Willd.) Link

Solidago sempervirens L.

Sparganium hyperboreum Laest.

Spartina alterniflora

Loiseleur

S. cynosuroides (L.) Roth

S. foliosa Trin.

S. patens (Ait.) Muhl.

Sphagnum spp.

Spiraea beauverdiana

C. K. Schneid.

S. douglasii Hook.

Spirodela spp.

Stellaria spp.
Common name ${ }^{\mathrm{b}}$

(Dock)

Ditch grasses

Widgeon grass

Arrowheads

Glassworts

(Samphire)

(Common pickleweed)

Willows

Feltleaf willow

Alaska bog willow

Ovalleaf willow

Diamondleaf willow

Netleaf willow

Water ferns

Greasewood

Bulrushes

Hardstem bulrush

Common threesquare

(Bulrush)

Whitetop

Seaside goldenrod

(Bur-reed)

Saltmarsh cordgrass

Big cordgrass

California cordgrass

Saltmeadow

cordgrass

Peat mosses

Alaska spiraea

(Spiraea)

Big duckweeds

(Chickweed)
Scientific name ${ }^{\mathrm{a}}$

Suaeda californica S. Wats.

Tamarix gallica L.

Taxodium distichum (L.)

L. C. Rich.

Thalassia testudinum

K. D. Koenig

Thuja occidentalis $\mathrm{L}$.

Tolypella spp.

Trapa natans L.

Triglochin maritimum $\mathrm{L}$.

Typha spp.

T. angustifolia L.

T. latifolia L.

Ulmus americana $\mathrm{L}$.

Ulva spp.

Utricularia spp.

$U$. macrorhiza LeConte

Vaccinium corymbosum L.

$V$. oxycoccos L.

V. uliginosum $\mathrm{L}$.

$V$. vitis-idaea L.

Vallisneria americana Michx.

Verrucaria spp.

Wolffia spp.

Woodwardia virginica (L.)

J. E. Smith

Xanthium strumarium L.

Xyris spp.

Xyris smalliana Nash

Zannichellia palustris L.

Zenobia pulverulenta

(W. Bartram) Pollard

Zizania aquatica $\mathrm{L}$.

Zizaniopsis miliacea (Michx.)

Doell \& Aschers.

Zostera marina L.

Zosterella dubia (Jacq.) Small
Common name ${ }^{b}$

(Sea blite)

Tamarisk

Bald cypress

Turtle grass

Northern white cedar

(Stoneworts)

Water nut

Arrow grass

Cattails

Narrow-leaved cattail

Common cattail

American elm

Sea lettuce

Bladderworts

(Bladderwort)

Highbush blueberry

Small cranberry

Bog blueberry

Mountain cranberry

Wild celery

(Lichens)

Watermeals

Virginia chain-fern

(Cocklebur)

Yellow-eyed grasses

(Yellow-eyed grass)

Horned pondweed

Honeycup

Wild rice

Southern wild rice

Eelgrass

Water stargrass 


\section{APPENDIX B}

\section{Scientific and Common Names of Animals}

Scientific name

Acmaea spp.

Acropora spp.

Agrenia spp.

Amphipholis spp.

Amphitrite spp.

Ancylus spp.

Anodonta spp.

Anodontoides spp.

Anopheles spp.

Aplexa spp.

Arenicola spp.

Asellus spp.

Baetis spp.

Balanus spp.

Bryocamptus spp.

Caenis spp.

Callianassa spp.

Cambarus spp.

Canthocamptus spp.

Cerianthus spp.

Chaetopterus spp.

Chironomus spp.

Chironomidae

Chthamalus spp.

Cnemidocarpa spp.

Crassostrea spp.

C. virginica (Geml.)

Dendraster spp.

Diamesa spp.

Donax spp.

Echinocardium spp.

Elliptio spp.

Emerita spp.

Ephemerella spp.

Erpobdella spp.

Eukiefferiella spp.

Eunapius spp.

Euzonus spp.

Gammarus spp.

Gelastocoris spp.

Gordonia ventalina L.

Helobdella spp.

Heteromeyenia spp.

Hippospongia spp.
Limpet

Staghorn corals

Springtails

Brittle stars

Terebellid worms

Freshwater mollusks

Freshwater mollusks

Freshwater mollusks

Mosquitos

Pouch snails

Lugworms

Isopods

Mayflies

Acorn barnacles

Harpacticoid copepods

Mayflies

Ghost shrimp

Crayfishes

Harpacticoid copepods

Sea anemones

Polychaete worms

Midges

Midges

Acorn barnacles

Tunicates

Oysters

Eastern oyster

Sand dollars

Midges

Wedge shells

Heart urchins

Freshwater mollusks

Mole crabs

Mayflies

Leeches

Midges

Freshwater sponges

Blood worms

Scuds

Toad bugs

Common sea fan

Leeches

Horse sponges

Encrusting sponges

${ }^{a}$ Most common names refer only to general groupings.

Scientific name

Homarus americanus

Milne-Edwards

Hydropsyche spp.

Lampsilis spp.

Ligia spp.

Limnodrilus spp.

Littorina spp.

Lumbriculus spp.

Lymnaea spp.

Macoma spp.

M. balthica (Linne)

Melita spp.

Mercenaria spp.

Modiolus spp.

Montipora spp.

Muricea spp.

Mya spp.

Mytilus spp.

Nassarius spp.

Nemoura spp.

Nereis spp.

Nerita spp.

Notonecta spp.

Oliva spp.

Orchestia spp.

Ostrea spp.

Parastenocaris spp.

Patella spp.

Pecten spp.

Petricola pholadiformis Lam.

Phyllognathopus viguieri

Maryek

Physa spp.

Pisaster spp.

Pisidium spp.

Placopecten spp.

Platyodon spp.

Pollicipes spp.

Porites spp.

Pristina spp.

Procambarus spp.

Psephenus spp.

Renilla spp.

Sabellaria spp.

Saldula spp.

Saxidomus spp.

Simulium spp.

Siphonaria spp.

Sphaerium spp.
Common name

American lobster

Caddisflies

Freshwater mollusks

Slaters

Oligochaete worms

Periwinkles

Oligochaete worms

Pond snails

Macomas

Baltic macoma

Amphipods

Quahogs

Mussels

Corals

Sea whips

Soft-shell clams

Mussels

Mud snails

Stone flies

Clam worms

Nerites

Back swimmers

Olive shells

Beach hoppers

Oysters

Copepods

Limpets

Scallops

False angel wing

Copepod

Snails

Sea stars

Fingernail clams

Deep-sea scallops

Boring clams

Gooseneck barnacles

Corals

Oligochaete worms

Crayfish

Riffle beetles

Sea pansies

Reef worms

Shore bugs

Venus clams

Black flies

False limpets

Fingernail clams 
Scientific name

Spongilla spp.

Strongylocentrotus spp.

Tabanus spp.

Tellina spp.

Tetraclita spp.

Thais spp.

\section{Common name}

Freshwater sponges

Sea urchins

Flies

Tellin shells

Acorn barnacles

Rock shells
Scientific name

Thyone spp.

Tivela stultorum (Mawe)

Tortopus spp.

Tubifex spp.

Uca spp.

Urechis spp.
Common name ${ }^{\mathrm{a}}$

Sea cucumbers

Pismo clam

Mayflies

Sewage worms

Fiddler crabs

Echiurid worms 


\section{APPENDIX C}

\section{Glossary of Terms}

acid Term applied to water with a $\mathrm{pH}$ less than 5.5.

alkaline Term applied to water with a $\mathrm{pH}$ greater than 7.4.

bar An elongated landform generated by waves and currents, usually running parallel to the shore, composed predominantly of unconsolidated sand, gravel, stones, cobbles, or rubble and with water on two sides.

beach A sloping landform on the shore of larger water bodies, generated by waves and currents and extending from the water to a distinct break in landform or substrate type (e.g., a foredune, cliff, or bank).

brackish Marine and Estuarine waters with Mixohaline salinity. The term should not be applied to inland waters (see page 25).

boulder Rock fragments larger than $60.4 \mathrm{~cm}$ (24 inches) in diameter.

broad-leaved deciduous Woody angiosperms (trees or shrubs) with relatively wide, flat leaves that are shed during the cold or dry season; e.g., black ash (Fraxinus nigra).

broad-leaved evergreen Woody angiosperms (trees or shrubs) with relatively wide, flat leaves that generally remain green and are usually persistent for a year or more; e.g., red mangrove (Rhizophora mangle).

calcareous Formed of calcium carbonate or magnesium carbonate by biological deposition or inorganic precipitation in sufficient quantities to effervesce carbon dioxide visibly when treated with cold 0.1 normal hydrochloric acid. Calcareous sands are usually formed of a mixture of fragments of mollusk shell, echinoderm spines and skeletal material, coral, foraminifera, and algal platelets (e.g., Halimeda).

channel "An open conduit either naturally or artificially created which periodically or continuously contains moving water, or which forms a connecting link between two bodies of standing water" (Langbein and Iseri 1960:5).

channel bank The sloping land bordering a channel. The bank has steeper slope than the bottom of the channel and is usually steeper than the land surrounding the channel.

circumneutral Term applied to water with a $\mathrm{pH}$ of 5.5 to 7.4.

codominant Two or more species providing about equal areal cover which in combination control the environment.

cobbles Rock fragments $7.6 \mathrm{~cm}$ ( 3 inches) to $25.4 \mathrm{~cm}$ (10 inches) in diameter.

deciduous stand A plant community where deciduous trees or shrubs represent more than $50 \%$ of the total areal coverage of trees or shrubs.

dominant The species controlling the environment.

dormant season That portion of the year when frosts occur (see U.S. Department of Interior, National Atlas 1970:110-111 for generalized regional delineation).

emergent hydrophytes Erect, rooted, herbaceous angiosperms that may be temporarily to permanently flooded at the base but do not tolerate prolonged inundation of the entire plant; e.g., bulrushes (Scirpus spp.), saltmarsh cordgrass.

emergent mosses Mosses occurring in wetlands, but generally not covered by water.

eutrophic lake Lake that has a high concentration of plant nutrients such as nitrogen and phosphorus. evergreen stand A plant community where evergreen trees or shrubs represent more than $50 \%$ of the total areal coverage of trees and shrubs. The canopy is never without foliage; however, individual trees or shrubs may shed their leaves (Mueller-Dombois and Ellenberg 1974).

extreme high water of spring tides The highest tide occurring during a lunar month, usually near the new or full moon. This is equivalent to extreme higher high water of mixed semidiurnal tides.

extreme low water of spring tides The lowest tide occurring during a lunar month, usually near the new or full moon. This is equivalent to extreme lower low water of mixed semidiurnal tides.

flat A level landform composed of unconsolidated sedimentsusually mud or sand. Flats may be irregularly shaped or elongate and continuous with the shore, whereas bars are generally elongate, parallel to the shore, and separated from the shore by water.

floating plant A non-anchored plant that floats freely in the water or on the surface; e.g., water hyacinth (Eichhornia crassipes) or common duckweed (Lemna minor).

floating-leaved plant A rooted, herbaceous hydrophyte with some leaves floating on the water surface; e.g., white water lily (Nymphaea odorata), floating-leaved pondweed (Potamogeton natans). Plants such as yellow water lily (Nuphar luteum) which sometimes have leaves raised above the surface are considered floating-leaved plants or emergents, depending on their growth habit at a particular site.

floodplain "a flat expanse of land bordering an old river..." (see Reid and Wood 1976:72, 84).

fresh Term applied to water with salinity less than $0.5 \%$ dissolved salts.

gravel A mixture composed primarily of rock fragments $2 \mathrm{~mm}$ $(0.08 \mathrm{inch})$ to $7.6 \mathrm{~cm}$ (3 inches) in diameter. Usually contains much sand.

growing season The frost-free period of the year (see U.S. Department of Interior, National Atlas 1970:110-111 for generalized regional delineation).

haline Term used to indicate dominance of ocean salt.

herbaceous With the characteristics of an herb; a plant with no persistent woody stem above ground.

histosols Organic soils (see Appendix D).

hydric soil Soil that is wet long enough to periodically produce anaerobic conditions, thereby influencing the growth of plants.

hydrophyte, hydrophytic Any plant growing in water or on a substrate that is at least periodically deficient in oxygen as a result of excessive water content.

hyperhaline Term to characterize waters with salinity greater than $40 \%$, due to ocean-derived salts.

hypersaline Term to characterize waters with salinity greater than $40 \%$, due to land-derived salts.

macrophytic algae Algal plants large enough either as individuals or communities to be readily visible without the aid of optical magnification.

mean high water The average height of the high water over 19 years. 
mean higher high tide The average height of the higher of two unequal daily high tides over 19 years.

mean low water The average height of the low water over 19 years.

mean lower low water The average height of the lower of two unequal daily low tides over 19 years.

mean tide level A plane midway between mean high water and mean low water.

mesohaline Term to characterize waters with salinity of 5 to $18 \%$, due to ocean-derived salts.

mesophyte, mesophytic Any plant growing where moisture and aeration conditions lie between extremes. (Plants typically found in habitats with average moisture conditions, not usually dry or wet.)

mesosaline Term to characterize waters with salinity of 5 to $18 \%$, due to land-derived salts.

mineral soil Soil composed of predominantly mineral rather than organic materials (see page 44).

mixohaline Term to characterize water with salinity of 0.5 to $30 \%$, due to ocean salts. The term is roughly equivalent to the term brackish.

mixosaline Term to characterize waters with salinity of 0.5 to $30 \%$, due to land-derived salts.

mud Wet soft earth composed predominantly of clay and siltfine mineral sediments less than $0.074 \mathrm{~mm}$ in diameter (Black 1968; Liu 1970).

needle-leaved deciduous Woody gymnosperms (trees or shrubs) with needle-shaped or scale-like leaves that are shed during the cold or dry season; e.g., bald cypress (Taxodium distichum).

needle-leaved evergreen Woody gymnosperms with green, needle-shaped, or scale-like leaves that are retained by plants throughout the year; e.g., black spruce (Picea mariana).

nonpersistent emergents Emergent hydrophytes whose leaves and stems break down at the end of the growing season so that most above-ground portions of the plants are easily transported by currents, waves, or ice. The breakdown may result from normal decay or the physical force of strong waves or ice. At certain seasons of the year there are no visible traces of the plants above the surface of the water; e.g., wild rice (Zizania aquatica), arrow arum (Peltandra virginica).

obligate hydrophytes Species that are found only in wetlandse.g., cattail (Typha latifolia) as opposed to ubiquitous species that grow either in wetland or on upland-e.g., red maple (Acer rubrum).

oligohaline Term to characterize water with salinity of 0.5 to $5.0 \%$, due to ocean-derived salts.

oligosaline Term to characterize water with salinity of 0.5 to $5.0 \%$, due to land-derived salts.

organic soil Soil composed of predominantly organic rather than mineral material. Equivalent to Histosol (see page 44).

persistent emergent Emergent hydrophytes that normally remain standing at least until the beginning of the next growing season; e.g., cattails (Typha spp.) or bulrushes (Scirpus spp.).

photic zone The upper water layer down to the depth of effective light penetration where photosynthesis balances respira- tion. This level (the compensation level) usually occurs at the depth of $1 \%$ light penetration and forms the lower boundary of the zone of net metabolic production.

pioneer plants Herbaceous annual and seedling perennial plants that colonize bare areas as a first stage in secondary succession. polyhaline Term to characterize water with salinity of 18 to $30 \%$, due to ocean salts.

polysaline Term to characterize water with salinity of 18 to $30 \%$, due to land-derived salts.

saline General term for waters containing various dissolved salts. We restrict the term to inland waters where the ratios of the salts often vary; the term haline is applied to coastal waters where the salts are roughly in the same proportion as found in undiluted sea water (see page 25).

salinity The total amount of solid material in grams contained in $1 \mathrm{~kg}$ of water when all the carbonate has been converted to oxide, the bromine and iodine replaced by chlorine, and all the organic matter completely oxidized.

sand Composed predominantly of coarse-grained mineral sediments with diameters larger than $0.074 \mathrm{~mm}$ (Black 1968) and smaller than $2 \mathrm{~mm}$ (Liu 1970; Weber 1973).

shrub A woody plant which at maturity is usually less than 6 $m$ (20 feet) tall and generally exhibits several erect, spreading, or prostrate stems and has a bushy appearance; e.g., speckled alder (Alnus rugosa) or buttonbush (Cephalanthus occidentalis).

sound A body of water that is usually broad, elongate, and parallel to the shore between the mainland and one or more islands.

spring tide The highest high and lowest low tides during the lunar month.

stone Rock fragments larger than $25.4 \mathrm{~cm}$ (10 inches) but less than $60.4 \mathrm{~cm}$ (24 inches).

submergent plant A vascular or nonvascular hydrophyte, either rooted or nonrooted, which lies entirely beneath the water surface, except for flowering parts in some species; e.g., wild celery (Vallisneria americana) or the stoneworts (Chara spp.).

terrigenous Derived from or originating on the land (usually referring to sediments) as opposed to material or sediments produced in the ocean (marine) or as a result of biologic activity (biogenous).

tree A woody plant which at maturity is usually $6 \mathrm{~m}$ (20 feet) or more in height and generally has a single trunk, unbranched for $1 \mathrm{~m}$ or more above the ground, and a more or less definite crown; e.g., red maple (Acer rubrum), northern white cedar (Thuja occidentalis).

water table The upper surface of a zone of saturation. No water table exists where that surface is formed by an impermeable body (Langbein and Iseri 1960:21).

woody plant A seed plant (gymnosperm or angiosperm) that develops persistent, hard, fibrous tissues, basically xylem; e.g., trees and shrubs.

xerophyte, xerophytic Any plant growing in a habitat in which an appreciable portion of the rooting medium dries to the wilting coefficient at frequent intervals. (Plants typically found in very dry habitats.) 


\section{APPENDIX D}

\section{Criteria for Distinguishing Organic Soils from Mineral Soils}

The criteria for distinguishing organic soils from mineral soils in the United States (U.S. Soil Conservation Service, Soil Survey Staff 1975:13-14,65) are quoted here so that those without ready access to a copy of the Soil Taxonomy may employ this information in the classification of wetlands:

For purposes of taxonomy, it is necessary, first, to define the limits that distinguish mineral soil material from organic soil material and, second, to define the minimum part of a soil that should be mineral if the soil is to be classified as a mineral soil.

Nearly all soils contain more than traces of both mineral and organic components in some horizons, but most soils are dominantly one or the other. The horizons that are less than about 20 to 35 percent organic matter by weight have properties that are more nearly those of mineral than of organic soils. Even with this separation, the volume of organic matter at the upper limit exceeds that of the mineral material in the fine-earth fraction.

\section{MINERAL SOIL MATERIAL}

Mineral soil material either

1. Is never saturated with water for more than a few days and has $<20$ percent organic carbon by weight; or

2. Is saturated with water for long periods or has been artificially drained, and has

a. Less than 18 percent organic carbon by weight if 60 percent or more of the mineral fraction is clay;

b. Less than 12 percent organic carbon by weight if the mineral fraction has no clay; or

c. A proportional content of organic cabon between 12 and 18 percent if the clay content of the mineral fraction is between zero and 60 percent.

Soil material that has more organic carbon than the amounts just given is considered to be organic material.

\section{DISTINCTION BETWEEN MINERAL SOILS AND ORGANIC SOILS}

Most soils are dominantly mineral material, but many mineral soils have horizons of organic material. For simplicity in writing definitions of taxa, a distinction between what is meant by a mineral soil and an organic soil is useful. In a mineral soil, the depth of each horizon is measured from the top of the first horizon of mineral material. In an organic soil, the depth of each horizon is measured from the base of the aerial parts of the growing plants or, if there is no continuous plant cover from the surface of the layer of organic materials. To apply the definitions of many taxa, therefore, one must first decide whether the soil is mineral or organic.

If a soil has both organic and mineral horizons, the relative thickness of the organic and the mineral soil materials must be considered. At some point one must decide that the mineral horizons are more important. This point is arbitrary and depends in part on the nature of the materials. A thick layer of sphagnum has a very low bulk density and contains less organic matter than a thinner layer of well-decomposed muck. It is much easier to measure thickness of layers in the field than it is to determine tons of organic matter per hectare. The definition of a mineral soil, therefore, is based on thickness of the horizons or layers, but the limits of thickness must vary with the kinds of materials. The definition that follows is intended to classify as mineral soils those that have no more organic material than the amount permitted in the histic epipedon, which is defined later in this chapter.

To determine whether a soil is organic or mineral, the thickness of horizons is measured from the surface of the soil whether that is the surface of a mineral or an organic horizon. Thus, any 0 horizon at the surface is considered an organic horizon, if it meets the requirements of organic soil material as defined later, and its thickness is added to that of any other organic horizons to determine the total thickness of organic soil materials.

\section{DEFINITION OF MINERAL SOILS}

Mineral soils, in this taxonomy, are soils that meet one of the following requirements:

1. Mineral soil material $<2 \mathrm{~mm}$ in diameter (the fine-earth fraction) makes up more than half the thickness of the upper $80 \mathrm{~cm}$ (31 in.);

2. The depth to bedrock is $<40 \mathrm{~cm}$ and the layer or layers of mineral soil directly above the rock either are $10 \mathrm{~cm}$ or more thick or have half or more of the thickness of the overlying organic soil material; or

3. The depth to bedrock is $240 \mathrm{~cm}$, the mineral soil material immediately above the bedrock is $10 \mathrm{~cm}$ or more thick, and either

a. Organic soil material is $<40 \mathrm{~cm}$ thick and is decomposed (consisting of hemic or sapric materials as defined later) or has a bulk density of 0.1 or more; or

b. Organic soil material is $<60 \mathrm{~cm}$ thick and either is undecomposed sphagnum or moss fibers or has a bulk density that is $<0.1$.

\section{ORGANIC SOIL MATERIALS}

Organic soil materials and organic soils

1. Are saturated with water for long periods or are artificially drained and, excluding live roots, (a) have 18 percent or more organic carbon if the mineral fraction is 60 percent or more clay, (b) have 12 percent or more organic carbon if the mineral fraction has no clay, or (c) have a proportional content of organic carbon between 12 and 18 percent if the clay content of the mineral fraction is between zero and 60 percent; or

2. Are never saturated with water for more than a few days and have 20 percent or more organic carbon.

Item 1 in this definition covers materials that have been called peats and mucks. Item 2 is intended to include what has been called litter or 0 horizons. Not all organic soil 
materials accumulate in or under water. Leaf litter may rest on a lithic contact and support a forest. The only soil in this situation is organic in the sense that the mineral fraction is appreciably less than half the weight and is only a small percentage of the volume of the soil.

\section{DEFINITION OF ORGANIC SOILS}

Organic soils (Histosols) are soils that

1. Have organic soil materials that extend from the surface to one of the following:

a. A depth within $10 \mathrm{~cm}$ or less of a lithic or paralithic contact, provided the thickness of the organic soil materials is more than twice that of the mineral soil above the contact; or

b. Any depth if the organic soil material rests on fragmental material (gravel, stones, cobbles) and the interstices are filled with organic materials, or rests on a lithic or paralithic contact; or

2. Have organic materials that have an upper boundary within $40 \mathrm{~cm}$ of the surface and

a. Have one of the following thicknesses:

(1) $60 \mathrm{~cm}$ or more if three-fourths or more of the volume is moss fibers or the moist bulk density is $<0.1 \mathrm{~g}$ per cubic centimeter (6.25 lbs per cubic foot);

(2) $40 \mathrm{~cm}$ or more if

(a) The organic soil material is saturated with water for long periods ( $>6$ months) or is artificially drained; and

(b) The organic material consists of sapric or hemic materials or consists of fibric materials that are less than three-fourths moss fibers by volume and have a moist bulk density of 0.1 or more; and

b. Have organic soil materials that

(1) Do not have a mineral layer as much as $40 \mathrm{~cm}$ thick either at the surface or whose upper boundary is within a depth of $40 \mathrm{~cm}$ from the surface; and

(2) Do not have mineral layers, taken cumulatively, as thick as $40 \mathrm{~cm}$ within the upper $80 \mathrm{~cm}$.

It is a general rule that a soil is classed as an organic soil (Histosol) either if more than half of the upper $80 \mathrm{~cm}$ (32 in.) [sic] of soil is organic or if organic soil material of any thickness rests on rock or on fragmental material having interstices filled with organic materials.

Soils that do not satisfy the criteria for classification as organic soils are mineral soils. 


\title{
APPENDIX E
}

\section{Artificial Keys to the Systems and Classes}

\author{
Key to the Systems
}

1. Water regime influenced by oceanic tides, and salinity due to ocean-derived salts $0.5 \%$ or greater.

2. Semi-enclosed by land, but with open, partly obstructed or sporadic access to the ocean. Halinity wide-ranging because of evaporation or mixing of seawater with runoff from land $\ldots \ldots \ldots \ldots \ldots \ldots \ldots$ ESTUARINE

2. Little or no obstruction to open ocean present. Halinity usually euhaline; little mixing of water with runoff

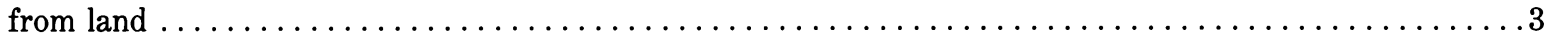

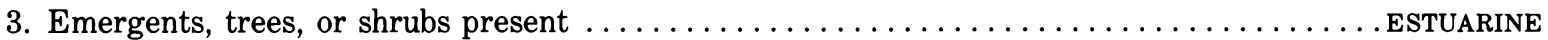

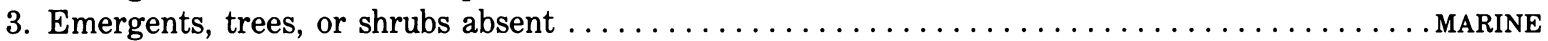

1. Water regime not influenced by ocean tides, or if influenced by oceanic tides, salinity less than $0.5 \%$.

4. Persistent emergents, trees, shrubs, or emergent mosses cover $30 \%$ or more of the area ..... PALUSTRINE

4. Persistent emergents, trees, shrubs, or emergent mosses cover less than $30 \%$ of substrate but nonpersistent

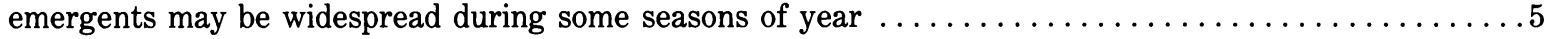

5. Situated in a channel; water, when present, usually flowing $\ldots \ldots \ldots \ldots \ldots \ldots \ldots \ldots \ldots$ RIVERINE

5. Situated in a basin, catchment, or on level or sloping ground; water usually not flowing $\ldots \ldots \ldots 6$

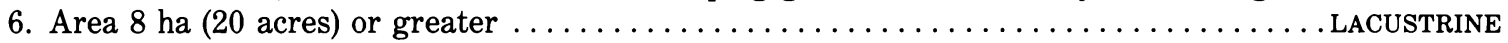

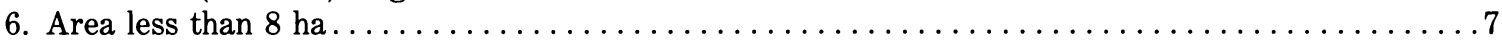

7. Wave-formed or bedrock shoreline feature present or water depth $2 \mathrm{~m}$ (6.6 feet)

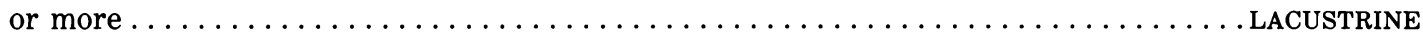

7. No wave-formed or bedrock shoreline feature present and water less than $2 \mathrm{~m}$ deep .PALUSTRINE

\section{Key to the Classes}

1. During the growing season of most years, areal cover by vegetation is less than $30 \%$.

2. Substrate a ridge or mound formed by colonization of sedentary invertebrates (corals, oysters,

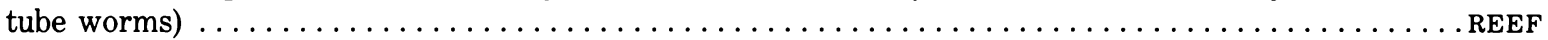

2. Substrate of rock or various-sized sediments often occupied by invertebrates but not formed by colonization

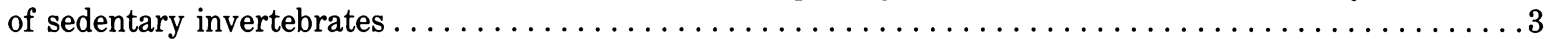

3. Water regime subtidal, permanently flooded, intermittently exposed, or semipermanently flooded. Substrate

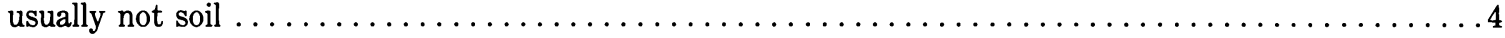

4. Substrate of bedrock, boulders, or stones occurring singly or in combination covers $75 \%$ or more of the

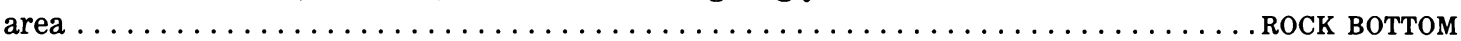

4. Substrate of organic material, mud, sand, gravel, or cobbles with less than $75 \%$ areal cover of stones,

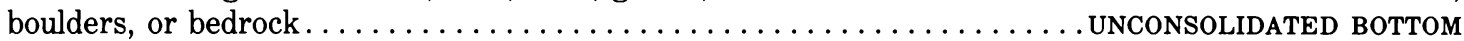

3. Water regime irregularly exposed, regularly flooded, irregularly flooded, seasonally flooded, temporarily flooded, intermittently flooded, saturated, or artificially flooded. Substrate often a soil ...........5

5. Contained within a channel that does not have permanent flowing water (i.e., Intermittent Subsystem of Riverine System or Intertidal Subsystem of Estuarine System) .............. STREAMBED

5. Contained in a channel with perennial water or not contained in a channel $\ldots \ldots \ldots \ldots \ldots \ldots$

6. Substrate of bedrock, boulders, or stones occurring singly or in combination covers $75 \%$ or more of

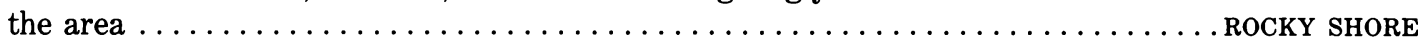

6. Substrate of organic material, mud, sand, gravel, or cobbles; with less than $75 \%$ of the cover consisting of stones, boulders, or bedrock

UNCONSOLIDATED SHORE

1. During the growing season of most years, percentage of area covered by vegetation $30 \%$ or greater.

7. Vegetation composed of pioneering annuals or seedling perennials, often not hydrophytes, occurring only at

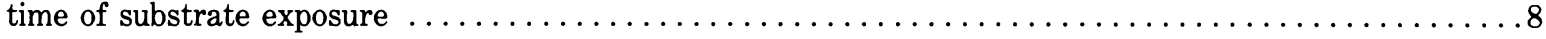

8. Contained within a channel that does not have permanent flowing water..... STREAMBED (VEGETATED)

8. Contained within a channel with permanent water, or not contained

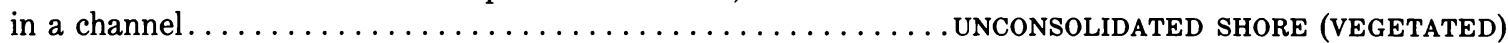


7. Vegetation composed of algae, bryophytes, lichens, or vascular plants that are usually hydrophytic

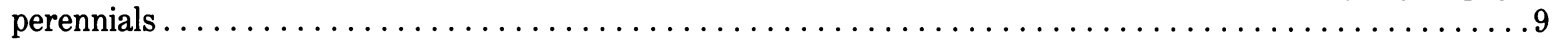

9. Vegetation composed predominantly of nonvascular species...................... 10

10. Vegetation macrophytic algae, mosses, or lichens growing in water or the

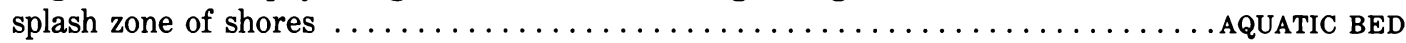

10. Vegetation mosses or lichens usually growing on organic soils and always outside the splash zone

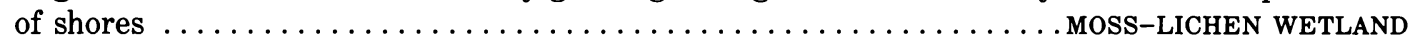

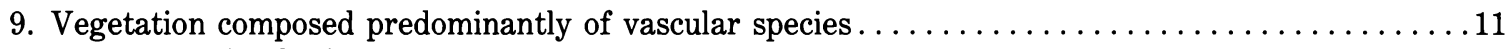

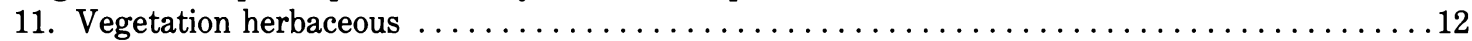

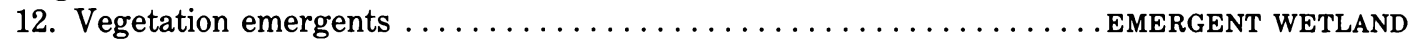

12. Vegetation submergent, floating-leaved, or floating $\ldots \ldots \ldots \ldots \ldots \ldots \ldots$ AQUATIC BED

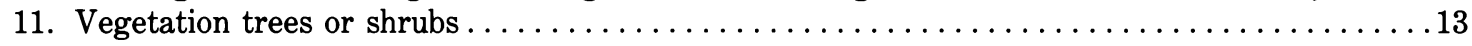

13. Dominants less than $6 \mathrm{~m}(20 \mathrm{feet})$ tall $\ldots \ldots \ldots \ldots \ldots \ldots \ldots \ldots$ SCRUB-SHRUB WETLAND

13. Dominants $6 \mathrm{~m}$ tall or taller $\ldots \ldots \ldots \ldots \ldots \ldots \ldots \ldots \ldots \ldots \ldots \ldots \ldots \ldots \ldots \ldots \ldots \ldots \ldots$ Forested WETLAND 


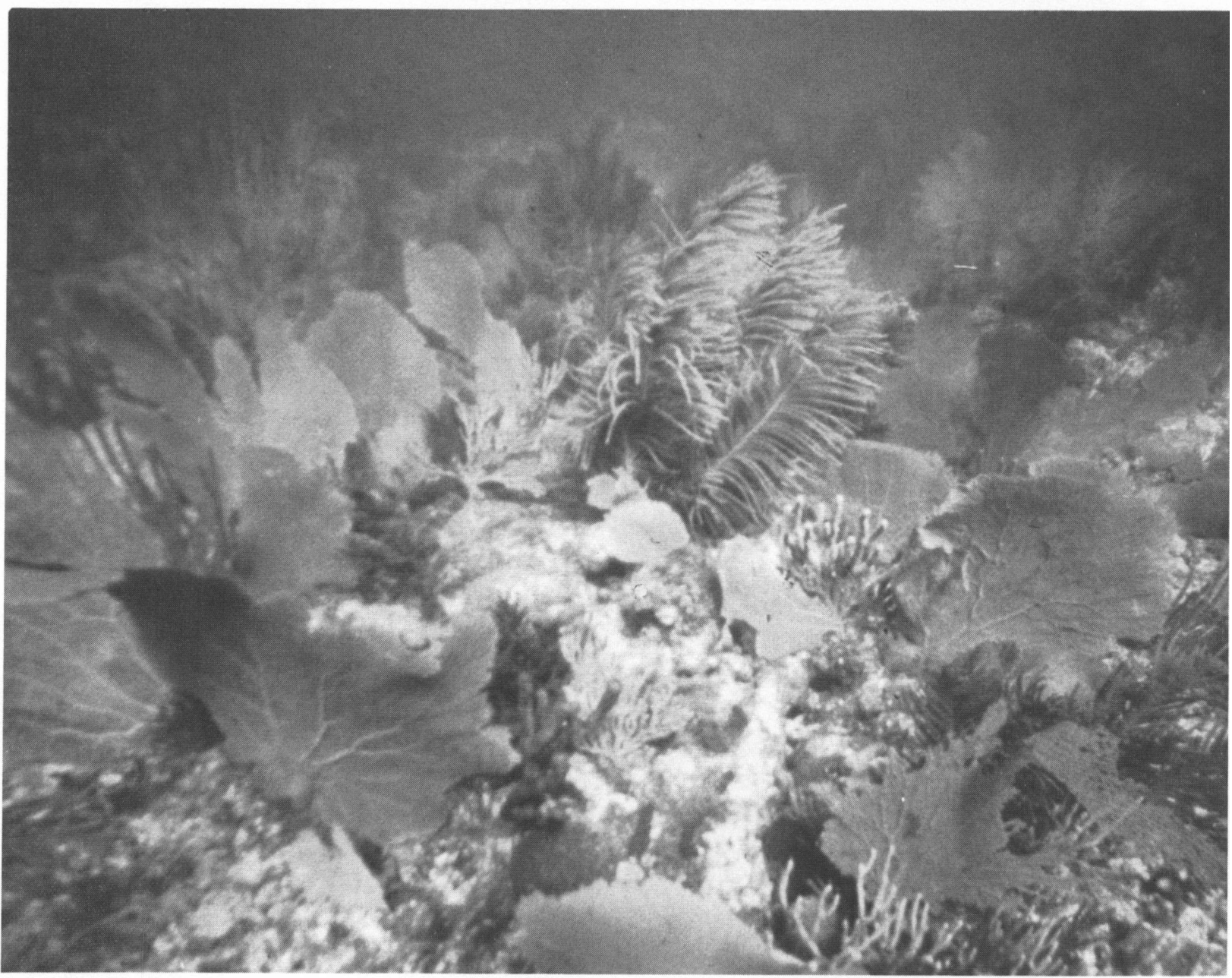

Plate 1.-Classification: sYSTEm Marine, subsystem Subtidal, ClASs Rock Bottom, SUBCLASs Bedrock, water REGIme Subtidal, WATER CHEMISTRY Euhaline. This underwater photograph shows colonies of common sea fans (Gorgonia ventalina) and other gorgonians living on bedrock. Bare rock is visible in the center and lower left corner of the photo. (Monroe County, Florida; July 1969; Photo by E. T. LaRoe) 


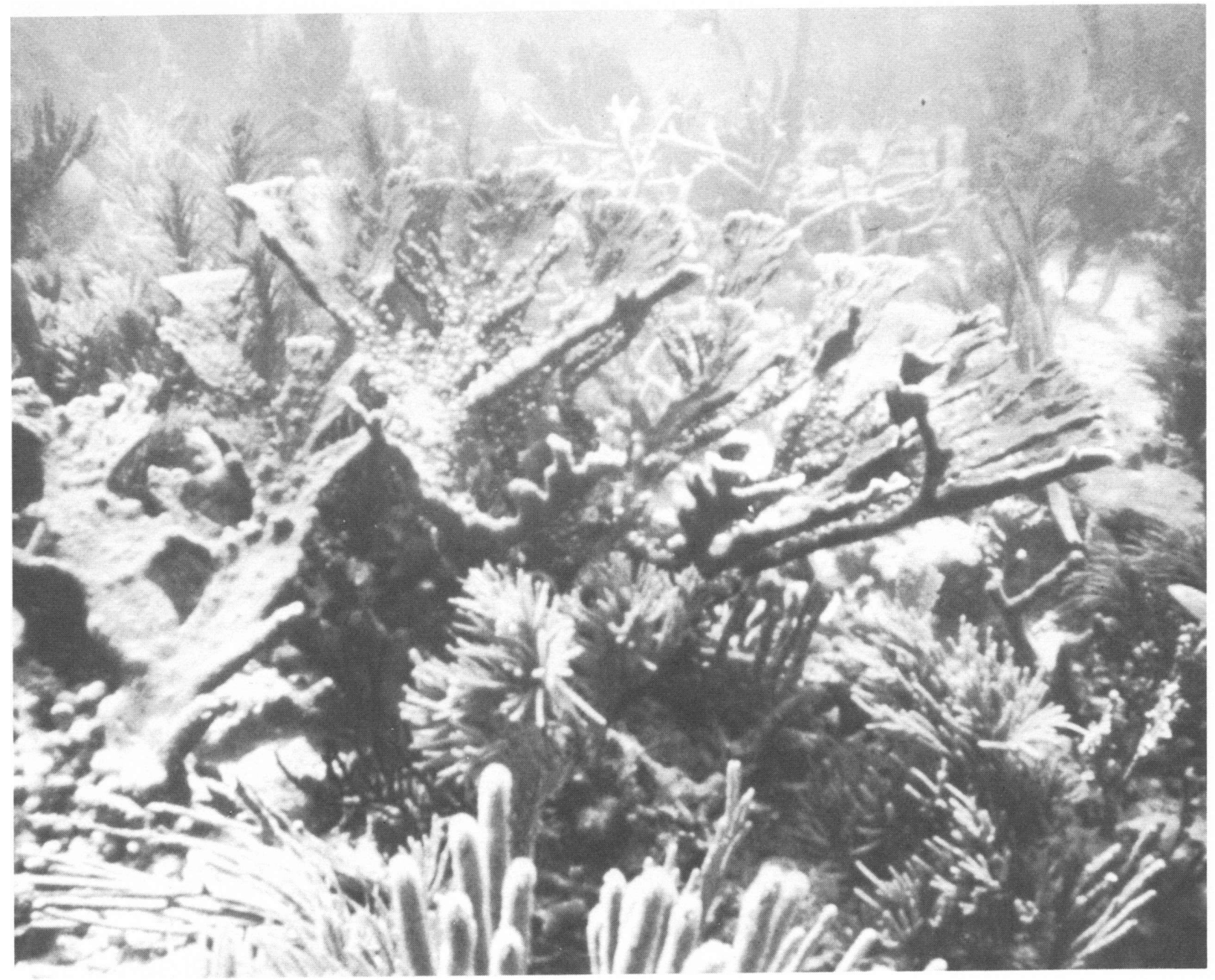

Plate 2.-Classification: SYSTEM Marine, SUBSyStem Subtidal, Class Reef, sUbClass Coral, WaTER REGime Subtidal, Water CHEMISTRY Euhaline. This underwater photograph shows corals (Acropora and Porites) as well as several species of gorgonians. (Monroe County, Florida; August 1970; Photo by E. T. LaRoe) 


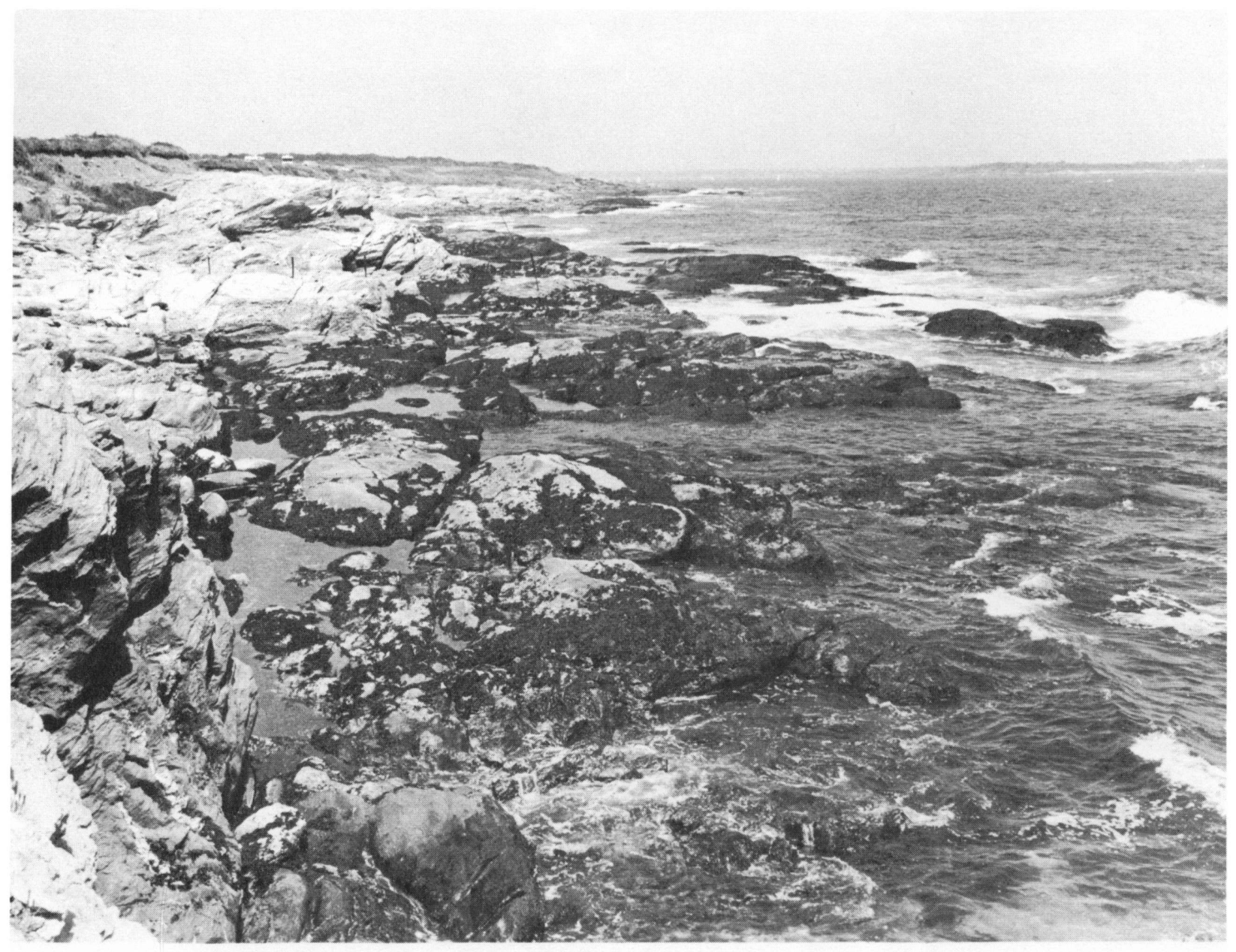

Plate 3.-Two habitats are shown here. Classification of landward (lighter) zone: SYSTEM Marine, SUBSYSTEM Intertidal, CLASS Rocky Shore, sUBCLASS Bedrock, WATER REGIME Irregularly Flooded, WATER CHEMISTRY Euhaline. Classification of seaward (darker) zone: SYSTEM Marine, SUBSYSTEM Intertidal, CLASS Aquatic Bed, SUBCLASS Algal, DOMINANCE TYPE Fucus spiralis, WATER REGIME Regularly Flooded, wATER CHEMISTRY Euhaline. Subordinate plants in the aquatic bed include rockweed (Fucus vesiculosus), knotted wrack (Ascophyllum nodosum), and Irish moss (Chondrus crispus). This photo was taken at low tide. (Newport County, Rhode Island; July 1977; Photo by F. C. Golet) 


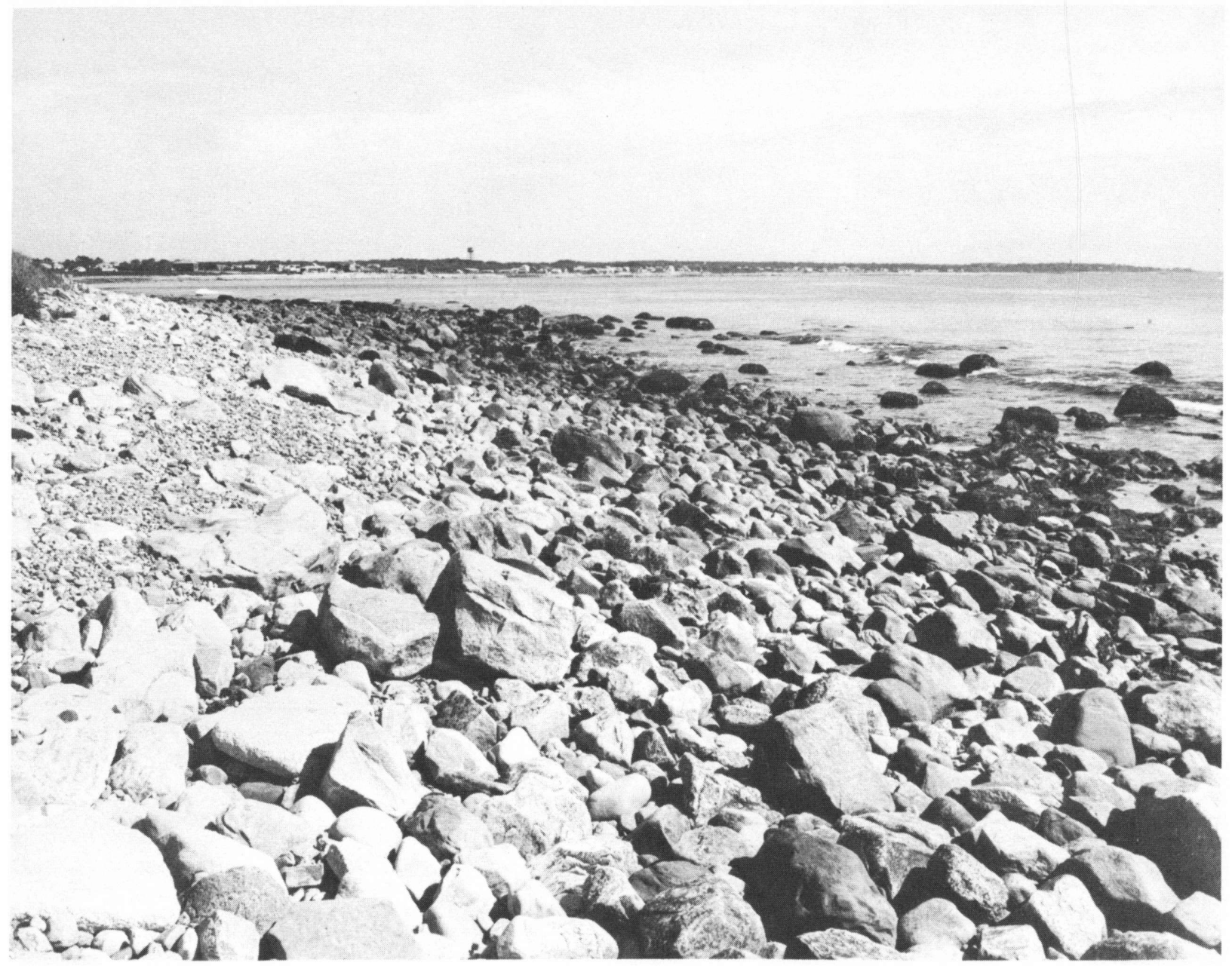

Plate 4.-Two habitats are shown here. Classification of landward (lighter) zone: SYSTEM Marine, sUBSYSTEM Intertidal, CLASS Rocky Shore, SUBCLASS Rubble, WATER REGIME Irregularly Flooded, WATER CHEMISTRY Euhaline. Classification of seaward (darker) zone: SYSTEM Marine, SUBSYSTEM Intertidal, CLASS Aquatic Bed, sUBCLASs Algal, DOMINANCE TYPE Fucus vesiculosus-Ascophyllum nodosum, WATER REGIME Regularly Flooded, WATER CHEMISTRY Euhaline. Most stones are larger than $30.5 \mathrm{~cm}$ (12 in) in diameter. (Washington County, Rhode Island; July 1977; Photo by F. C. Golet) 


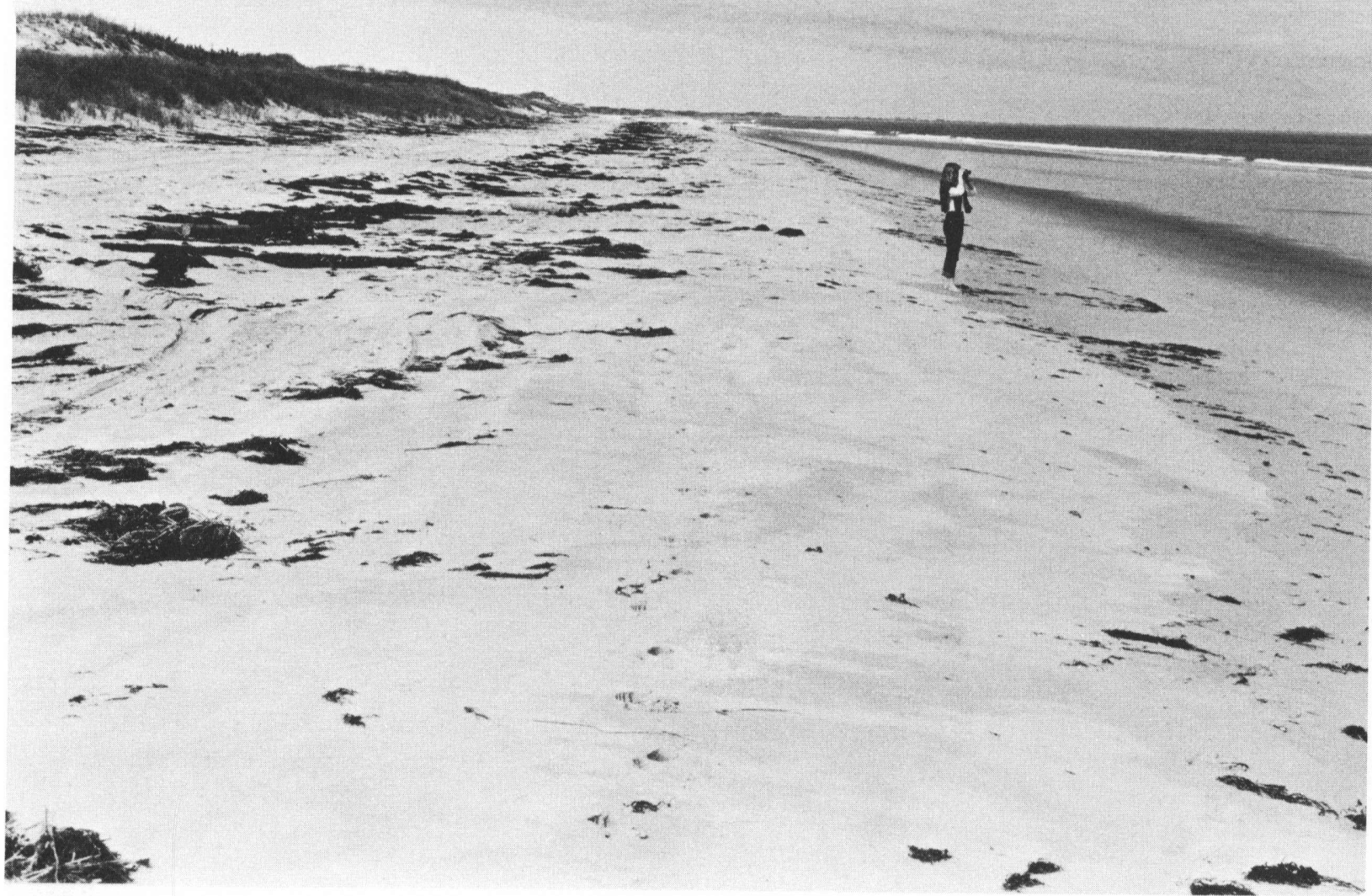

Plate 5.-Classification: SYstem Marine, SUBSystem Intertidal, Class Unconsolidated Shore, sUbCLASS Sand, WATER REGIMES Regularly Flooded (seaward from the woman to the breaking waves) and Irregularly Flooded (landward from the woman to the base of the sand dunes), WATER CHEMISTRY Euhaline. Lines of wrack (dead Fucus spp., Ascophyllum nodosum, and Zostera marina) on the beach mark the landward limit of various high tides during the past several days. The photo was taken at low tide. (Parker River National Wildlife Refuge, Essex County, Massachusetts; September 1985; Photo by F. C. Golet) 


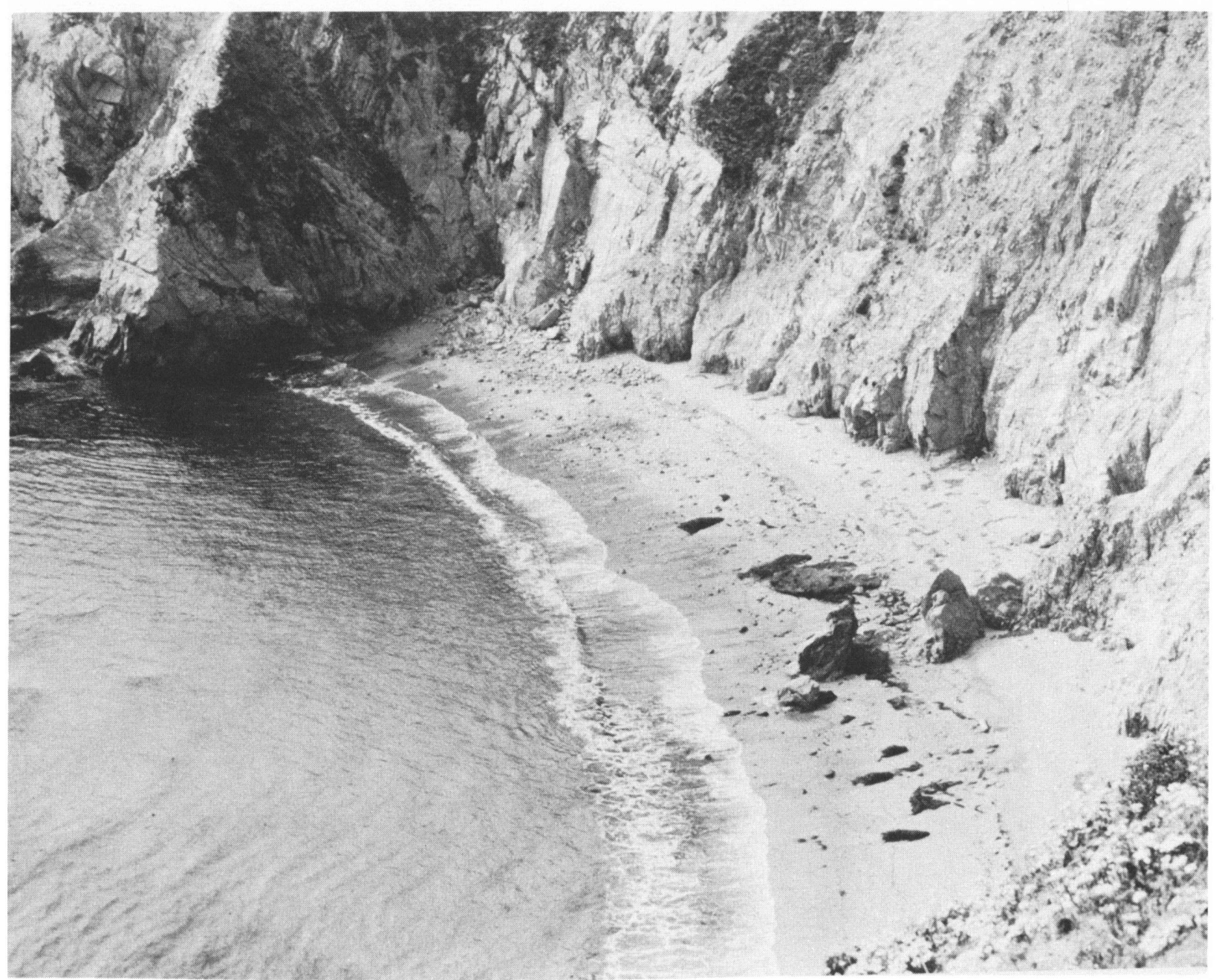

Plate 6.-Classification: SYSTEM Marine, SUBSYSTEM Intertidal, CLASS Unconsolidated Shore, SUBCLASS Sand, WATER REgIMES Regularly Flooded (lower two-thirds of beach) and Irregularly Flooded (upper one-third of beach near base of cliffs), waTER CHEMISTRY Euhaline. (Point Reyes National Seashore, Marin County, California; August 1975; Photo by V. Carter) 


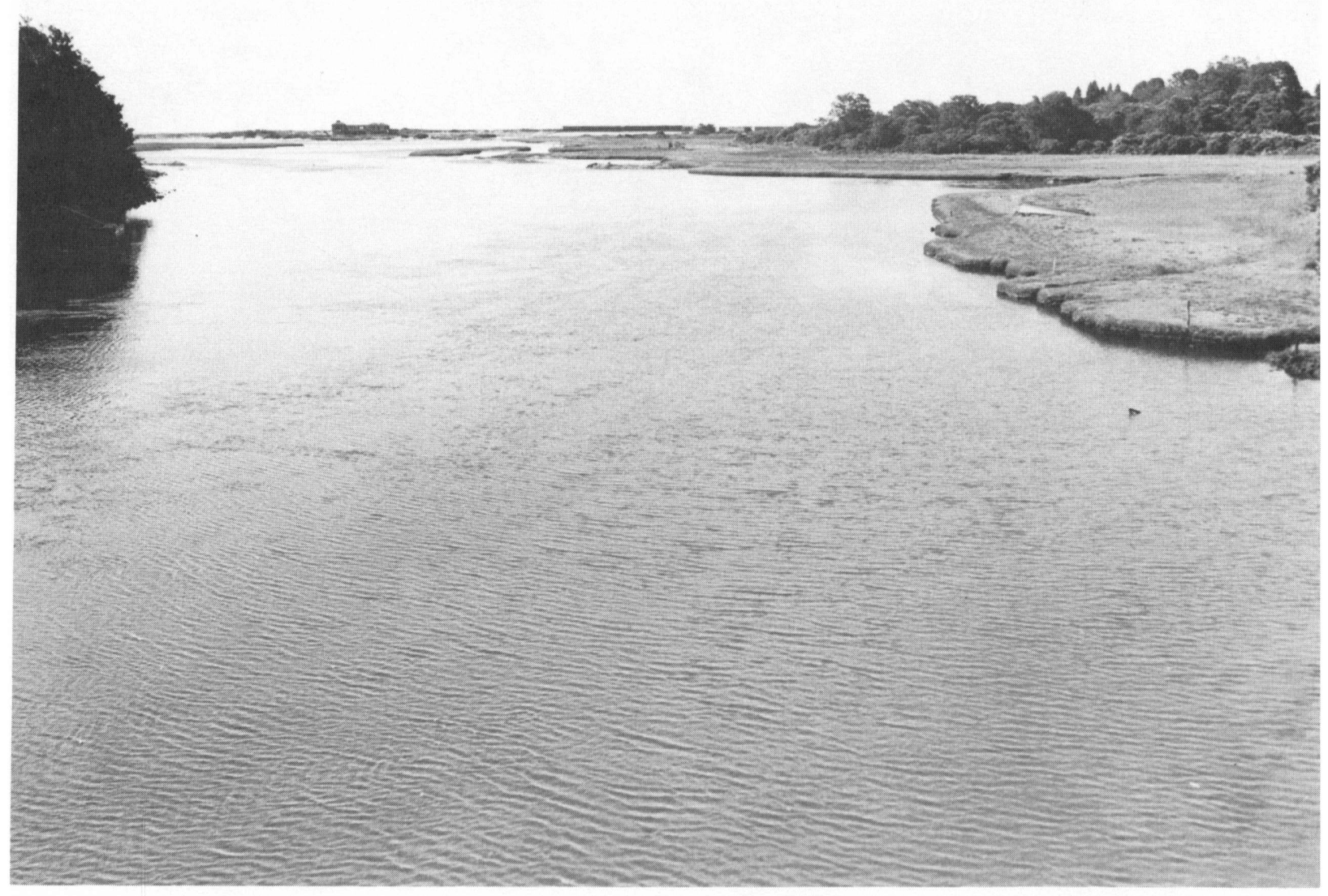

Plate 7.-Classification: SYSTEM Estuarine, SUBSYstem Subtidal, CLASS Unconsolidated Bottom, SUBCLASS Sand, wATER REGIME Subtidal, WATER CHEMISTRY Mixohaline. An irregularly flooded persistent-emergent wetland dominated by saltmarsh cordgrass (Spartina alterniflora) and saltmeadow cordgrass (Spartina patens) is shown in the right background (Washington County, Rhode Island; July 1977; Photo by F. C. Golet) 


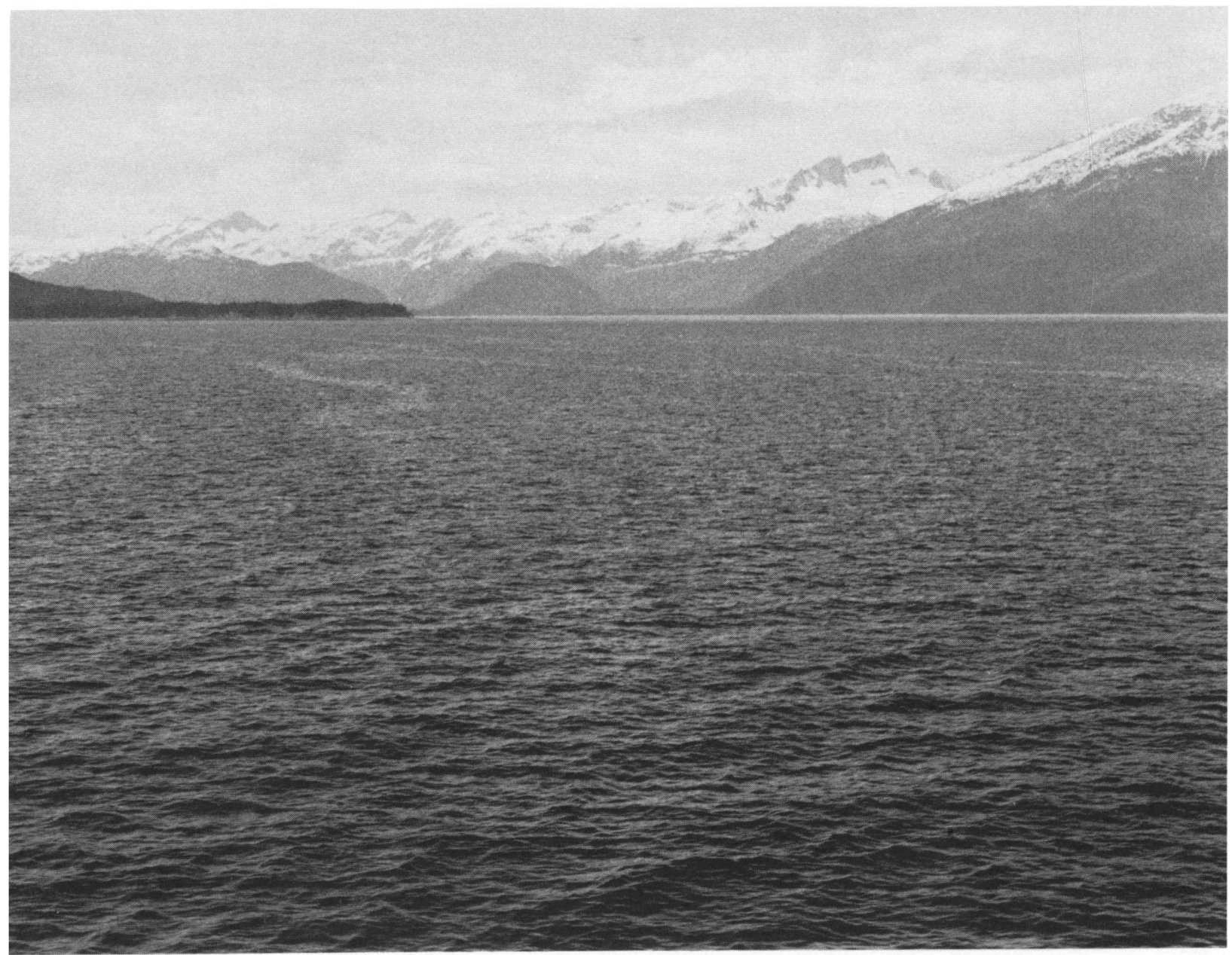

Plate 8.-Classification: SYSTEm Estuarine, subsystem Subtidal, Class Unconsolidated Bottom, subClaSs Mud, water REgIME Subtidal, WATER CHEMISTRY Mixohaline. This site lies within the Fjord Biogeographic Province. Glacier-mantled mountains plunge steeply into water more than $180 \mathrm{~m}$ (600 ft) deep. (Lynn Canal, Haines Borough, Alaska; June 1985; Photo by F. C. Golet) 


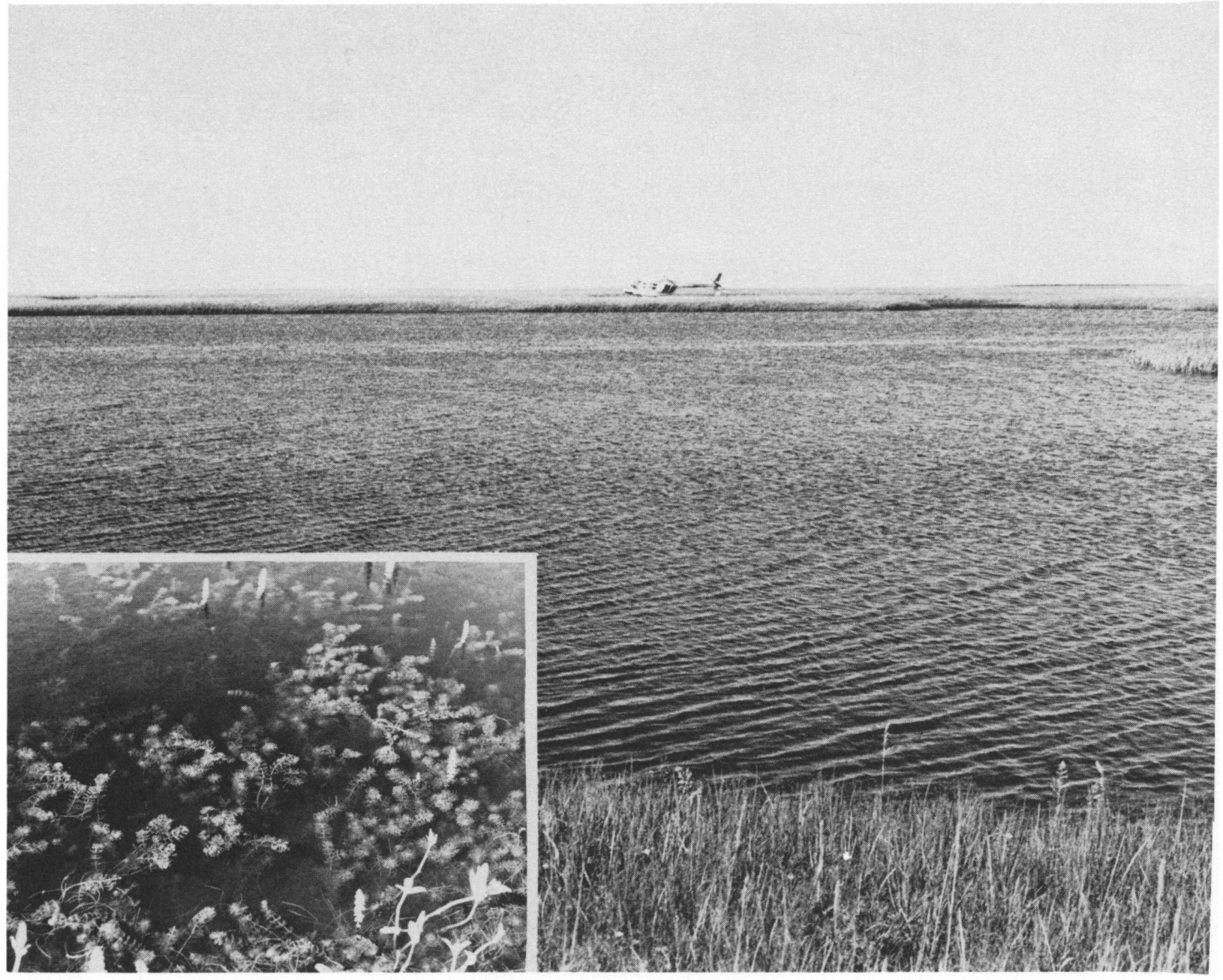

Plate 9.-Classification: sYSTEm Estuarine, subsystem Subtidal, Class Aquatic Bed, subCLASS Rooted Vascular, DominanCE TYPE Myriophyllum spicatum, WATER REGIME Subtidal, WATER CHEMISTRY Mixohaline. Subordinate plant species include mare's tail (Hippuris tetraphylla) and crowfoot (Ranunculus pallasii). This pond is located on coastal tundra; it is flooded with tidal water only during exceptionally high tides (less often than monthly). Plants characterizing the aquatic bed are shown in the photo-inset. (Between Azun and Narokachik Rivers, Yukon-Kuskokwim Delta, Alaska; July 1985; Photo by F. C. Golet) 


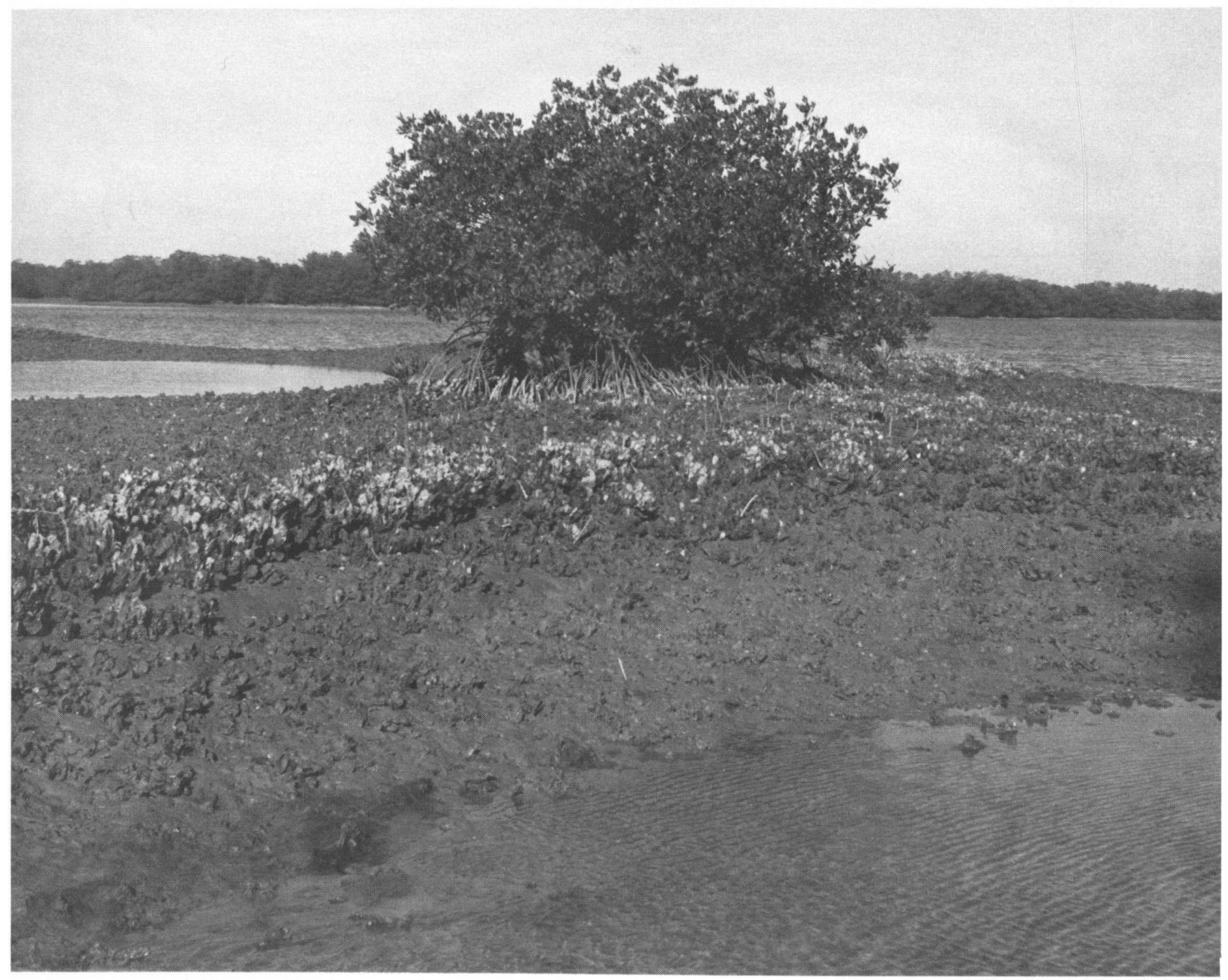

Plate 10.-Classification: SYSTEM Estuarine, sUBSYSTEM Intertidal, CLASS Reef, sUBCLASS Mollusk, DOMINANCE TYPE Crassostrea virginica, WATER REGIME Regularly Flooded, wATER CHEMISTRY Mixohaline. An individual red mangrove (Rhizophora mangle) has become established on this oyster reef. (Rookery Bay Sanctuary, Collier County, Florida; January 1978; Photo by E. T. LaRoe) 


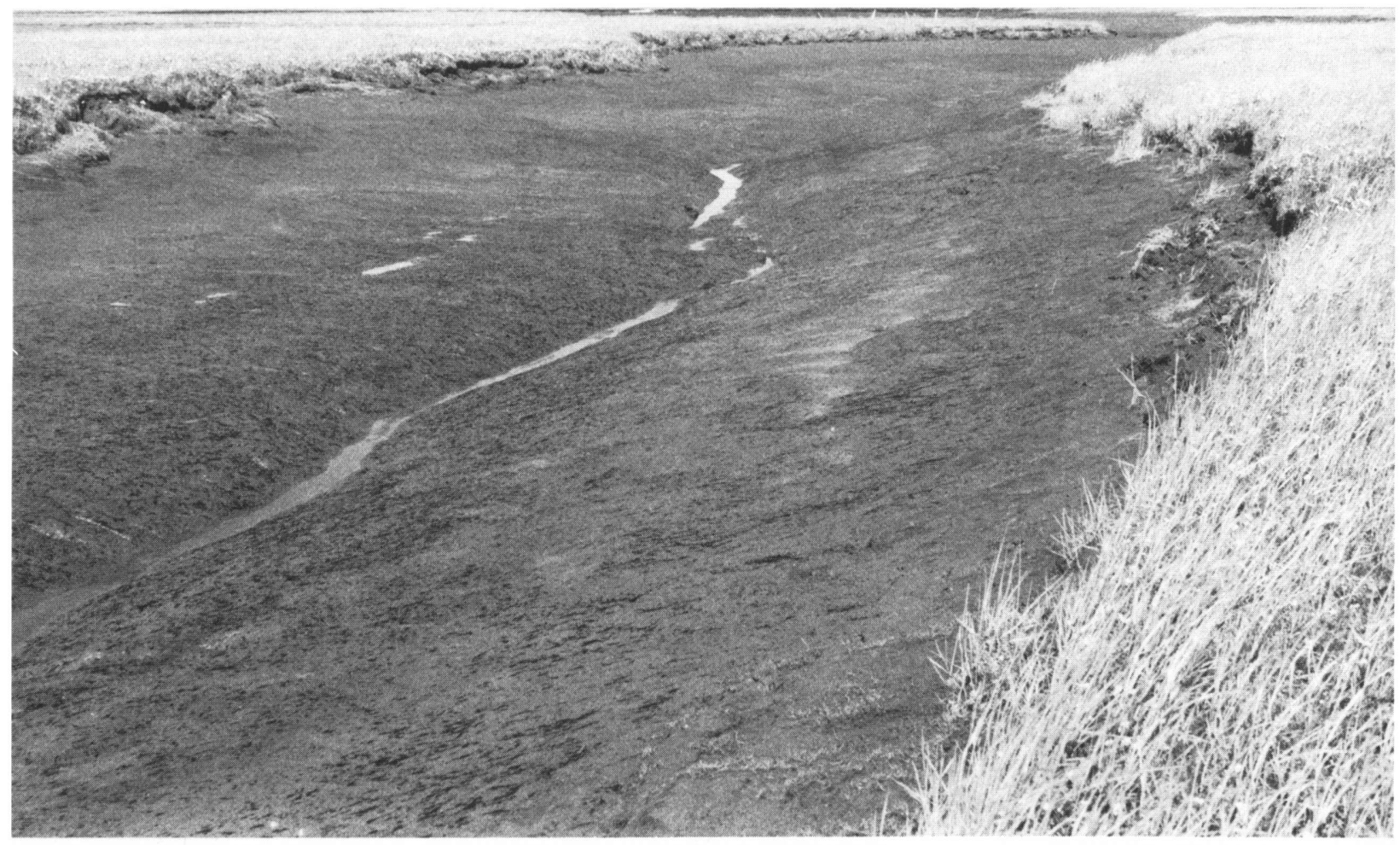

Plate 11.-Classification: SYSTEM Estuarine, SUBSYSTEM Intertidal, class Streambed, sUBCLASS Mud, WATER REGIME Regularly Flooded, WATER CHEMISTRY Mixohaline. This photo was taken at low tide; at high tide, the entire channel is flooded. The channel is flanked by irregularly flooded persistent-emergent wetland supporting such plants as: lyme grass (Elymus arenarius), beach lovage (Ligusticum scothicum), silverweed (Potentilla anserina), sedges (Carex ramenskii, C. bipartita), ovalleaf willow (Salix ovalifolia), and Arctic daisy (Dendranthema arcticum). This site lies $100 \mathrm{~m}$ from Angyoyaravak Bay, on the Bering Sea. (Tutakoke River area, Yukon-Kuskokwim Delta, Alaska; July 1985; Photo by F. C. Golet) 


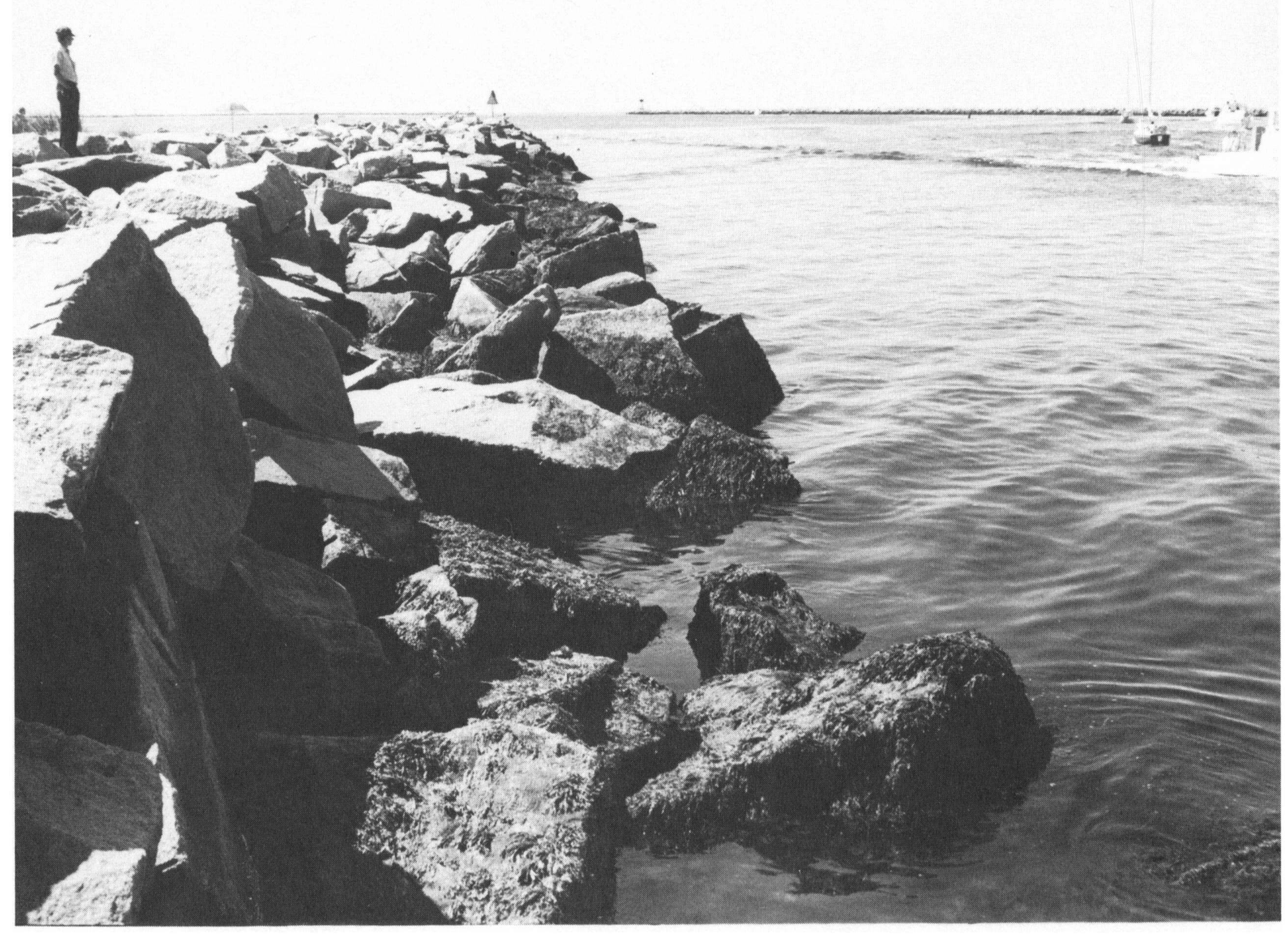

Plate 12.-Two habitats lie at the edge of this manmade breakwater. Classification of upper (lighter) zone: SYSTEM Estuarine, SUBSYSTEM Intertidal, CLASS Rocky Shore, subCLASS Rubble, WATER REgIME Irregularly Flooded, WATER CHEMISTRY Euhaline, SPECIAL MODIFIER Artificial. Classification of lower (darker) zone: sYSTEM Estuarine, sUBSYSTEM Intertidal, CLASS Aquatic Bed, SUBCLASS Algal, DOMINANCE TYPE Fucus vesiculosus, WATER REgIme Regularly Flooded, Water ChEMISTRY Euhaline, SPECIAL MODIFIER Artificial. (Washington County, Rhode Island; July 1977; Photo by F. C. Golet) 


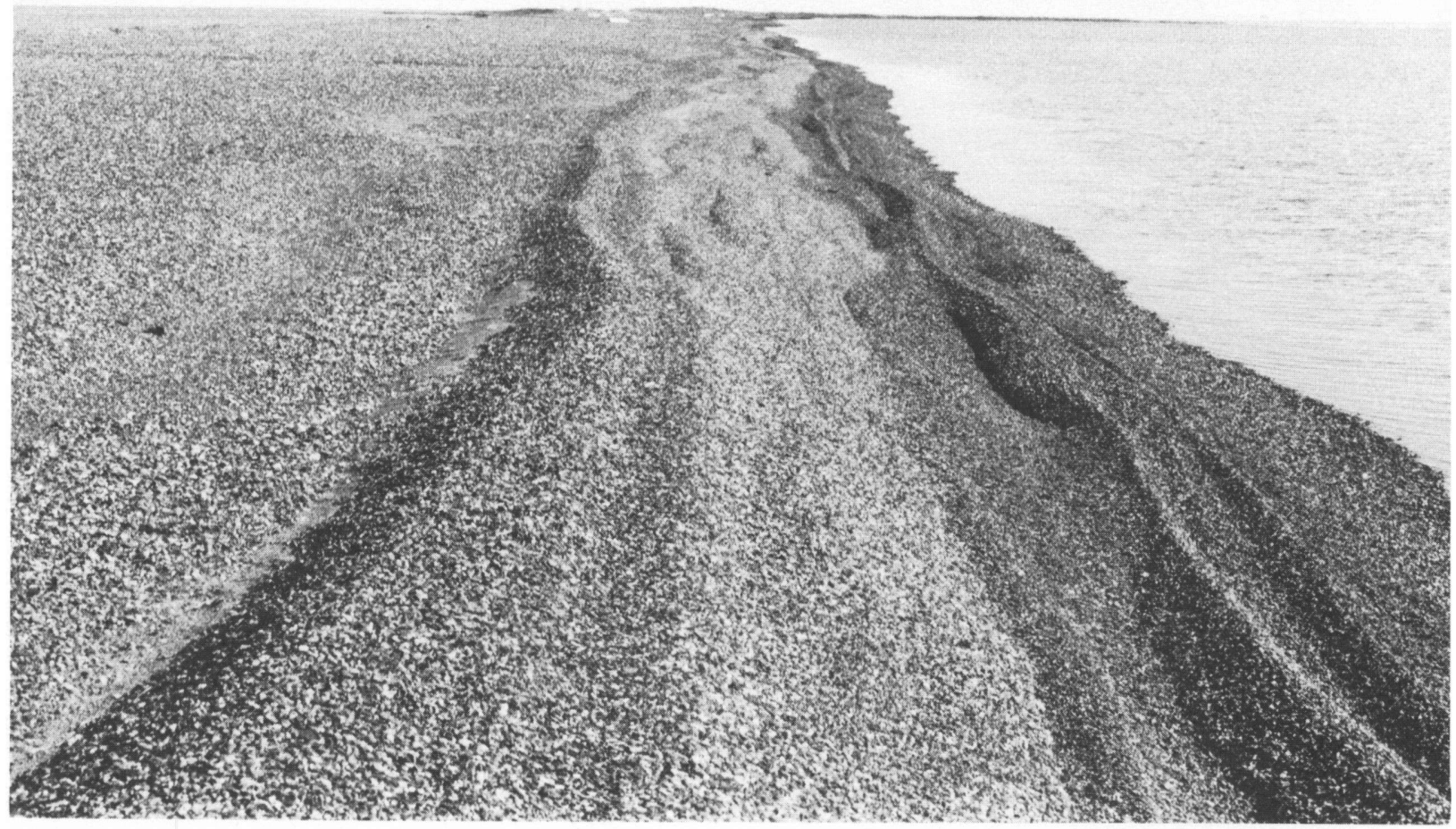

Plate 13.-Classification: SYSTEM Estuarine, SUBSYSTEM Intertidal, CLASs Unconsolidated Shore, SUBCLASs Cobble-Gravel, wATER REGIMES Regularly Flooded (darker zone at edge of water) and Irregularly Flooded (remainder of shore), WATER CHEMISTRY Euhaline. Mean tidal range in this area of the Arctic Ocean is approximately $15 \mathrm{~cm}$ (6 in). (Mikkelsen Bay, North Slope Borough, Alaska; July 1985; Photo by F. C. Golet) 


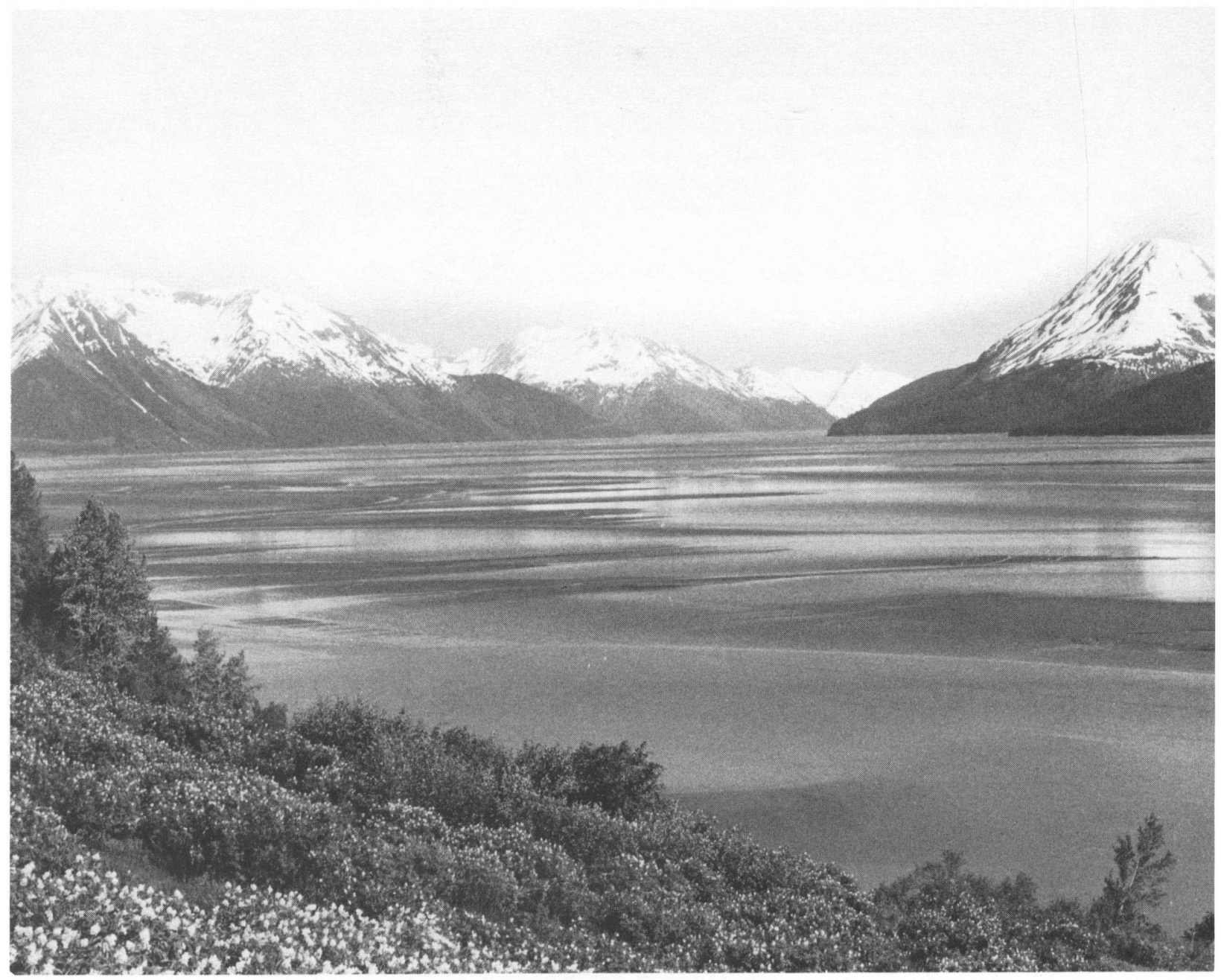

Plate 14.-Classification: SYSTEM Estuarine, SUBSYSTEM Intertidal, CLASS Unconsolidated Shore, sUBCLASS Mud, WATER REGIME Regularly Flooded, wATER ChEmISTRY Mixohaline. Turnagain Arm, a large bay off Cook Inlet, is 4-7 km (2.5-4 mi) wide at this

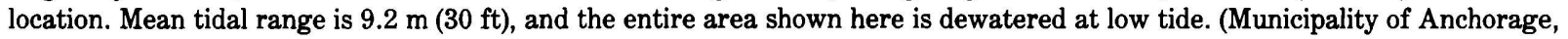
Alaska; June 1985; Photo by F. C. Golet) 


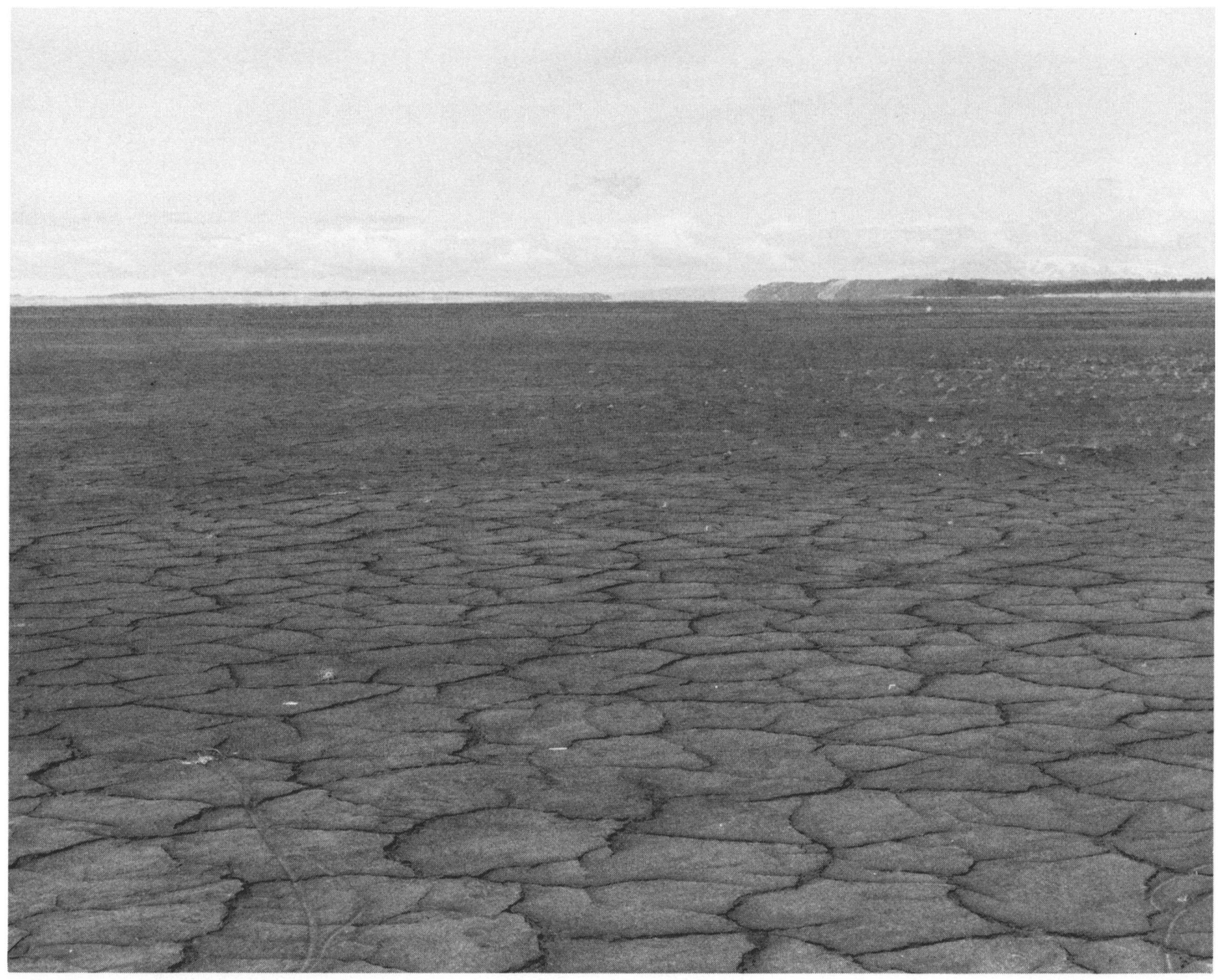

Plate 15.-Classification: SYSTEM Estuarine, SUBSYSTEm Intertidal, CLASS Unconsolidated Shore, SUBCLASS Mud, WATER REGIME Irregularly Flooded, WATER CHEMISTRY Mixohaline, soIL Mineral. Alkali grass (Puccinellia grandis) grows in widely scattered clumps at the right-hand edge of the photo. Mean tidal range at Fire Island (background left) is $7.4 \mathrm{~m}$ (24.4 ft). The cracks on these mud flats are evidence of the irregularly flooded tidal regime. (Municipality of Anchorage, Alaska; June 1985; Photo by F. C. Golet) 


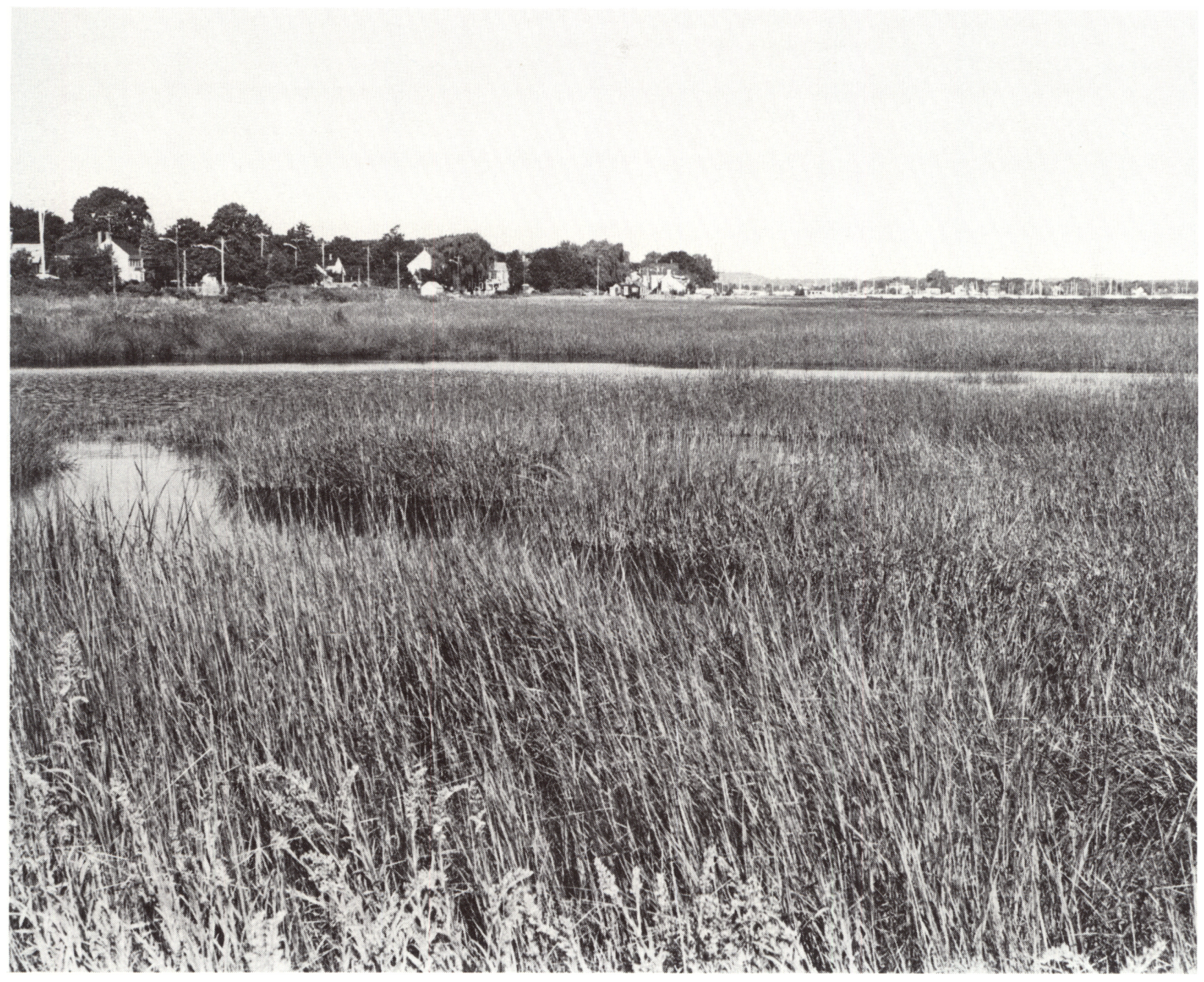

Plate 16.-Classification: SYSTEM Estuarine, SUBSYSTEM Intertidal, CLASS Emergent Wetland, sUBCLASS Persistent, DOMINANCE TYPE Spartina alterniflora, WATER REGIME Regularly Flooded, WATER CHEMISTRY Mixohaline, soIL Mineral. Saltmarsh cordgrass is the only plant growing in the regularly flooded zone of this salt marsh. Saltmeadow cordgrass (Spartina patens), seaside goldenrod (Solidago sempervirens), and the sedge, Carex paleacea, grow at the landward edge of the marsh. The photo was taken at high tide. (Essex County, Massachusetts; September 1985; Photo by F. C. Golet) 


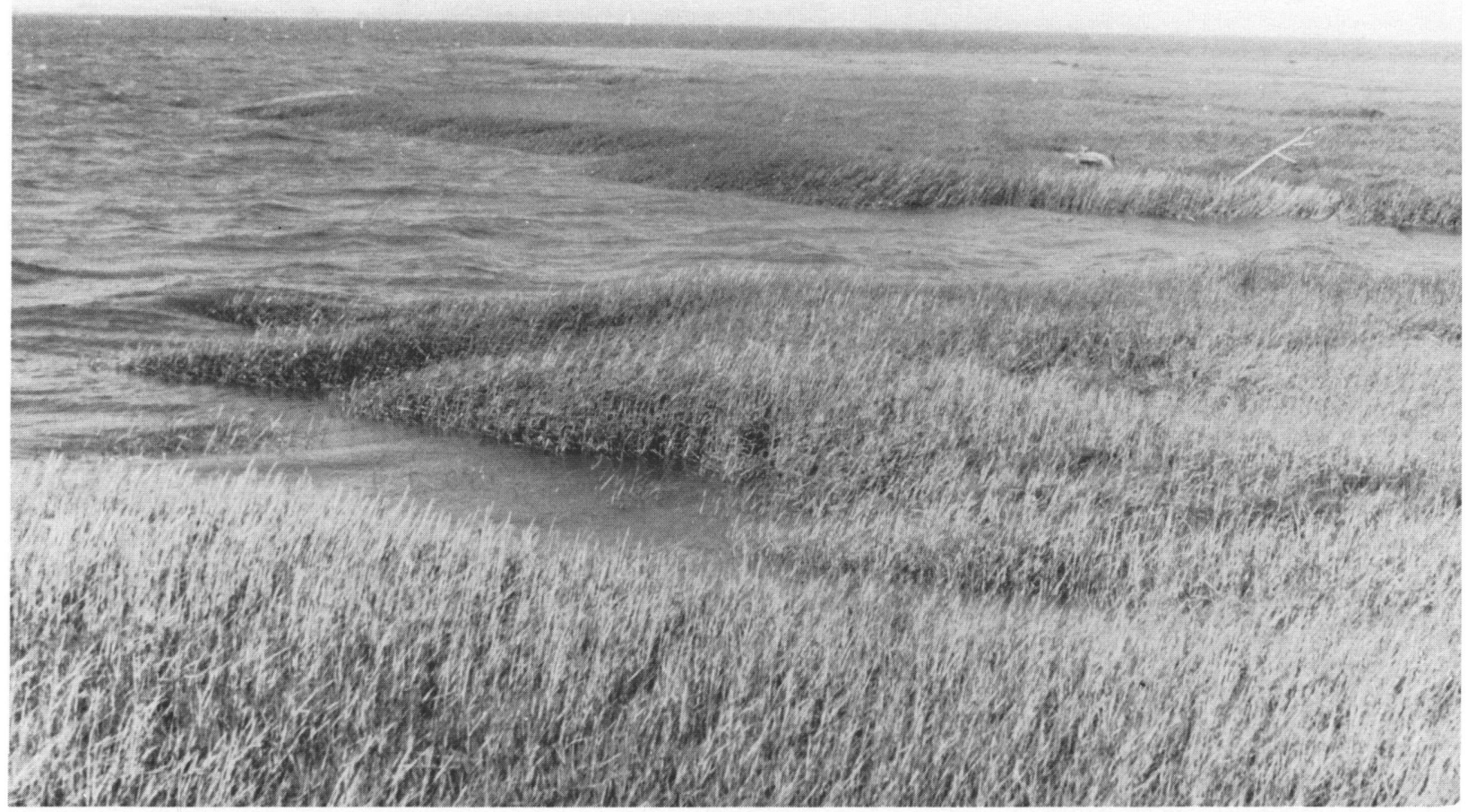

Plate 17.-Classification: SYSTEM Estuarine, SUbSYstem Intertidal, CLASs Emergent Wetland, subClass Persistent, DominanCE TYPE Spartina foliosa, WATER REGIME Regularly Flooded, water CHEMISTRY Mixohaline, soIL Mineral. The most common subordinate plants are glassworts (Salicornia spp.). This wetland borders an irregularly flooded emergent wetland dominated by glasswort. The photo was taken at high tide. (San Mateo County, California; August 1976; Photo by V. Carter) 


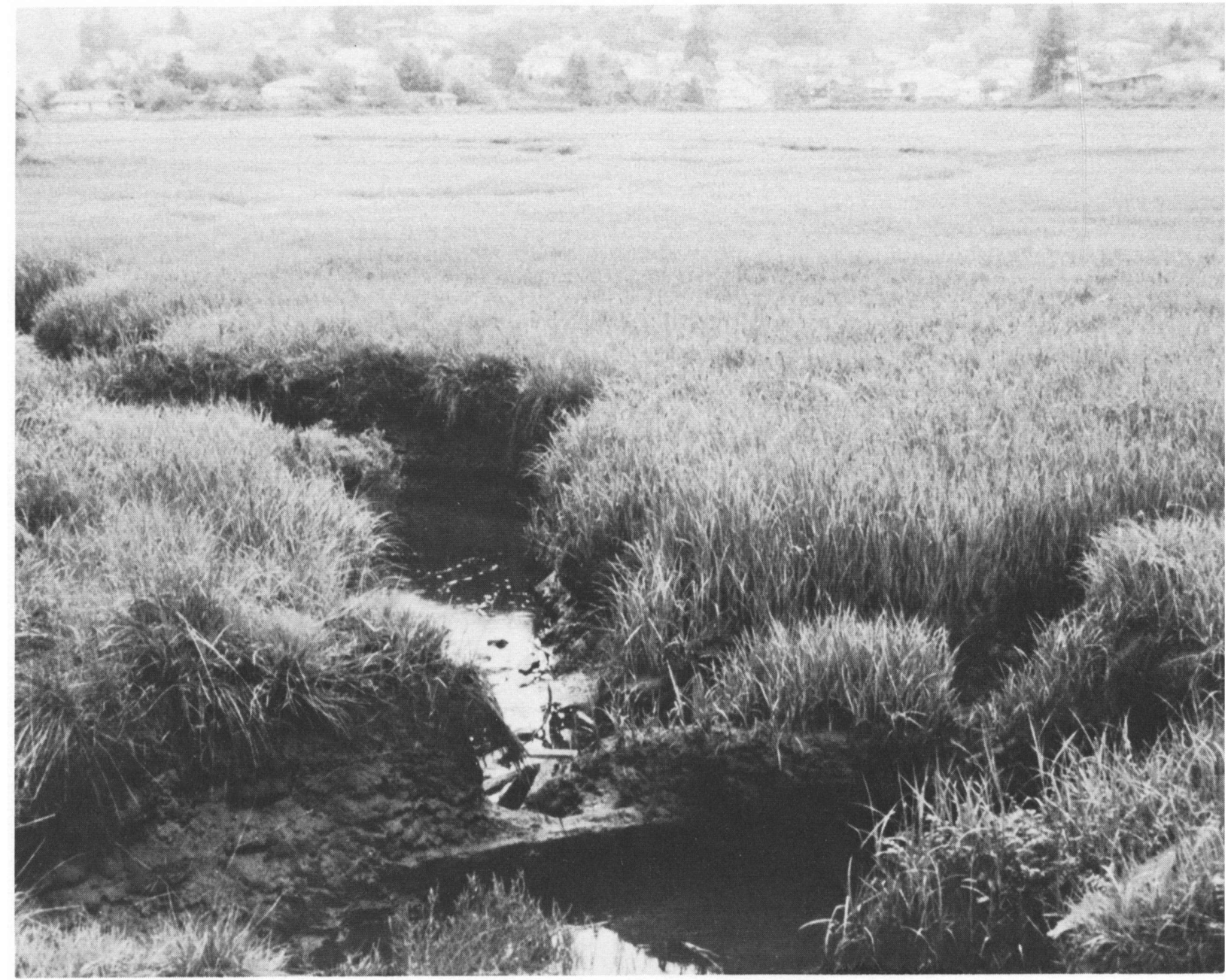

Plate 18.-Classification: SYSTEM Estuarine, SUBSYSTEM Intertidal, CLASs Emergent Wetland, SUBCLASS Persistent, DOMINANCE TYPE Carex lyngbyei, WATER REgIME Regularly Flooded, WATER ChEMISTRY Mixohaline, soll Organic. The photo was taken at low tide. (Coos County, Oregon; May 1977; Photo by D. D. Peters) 


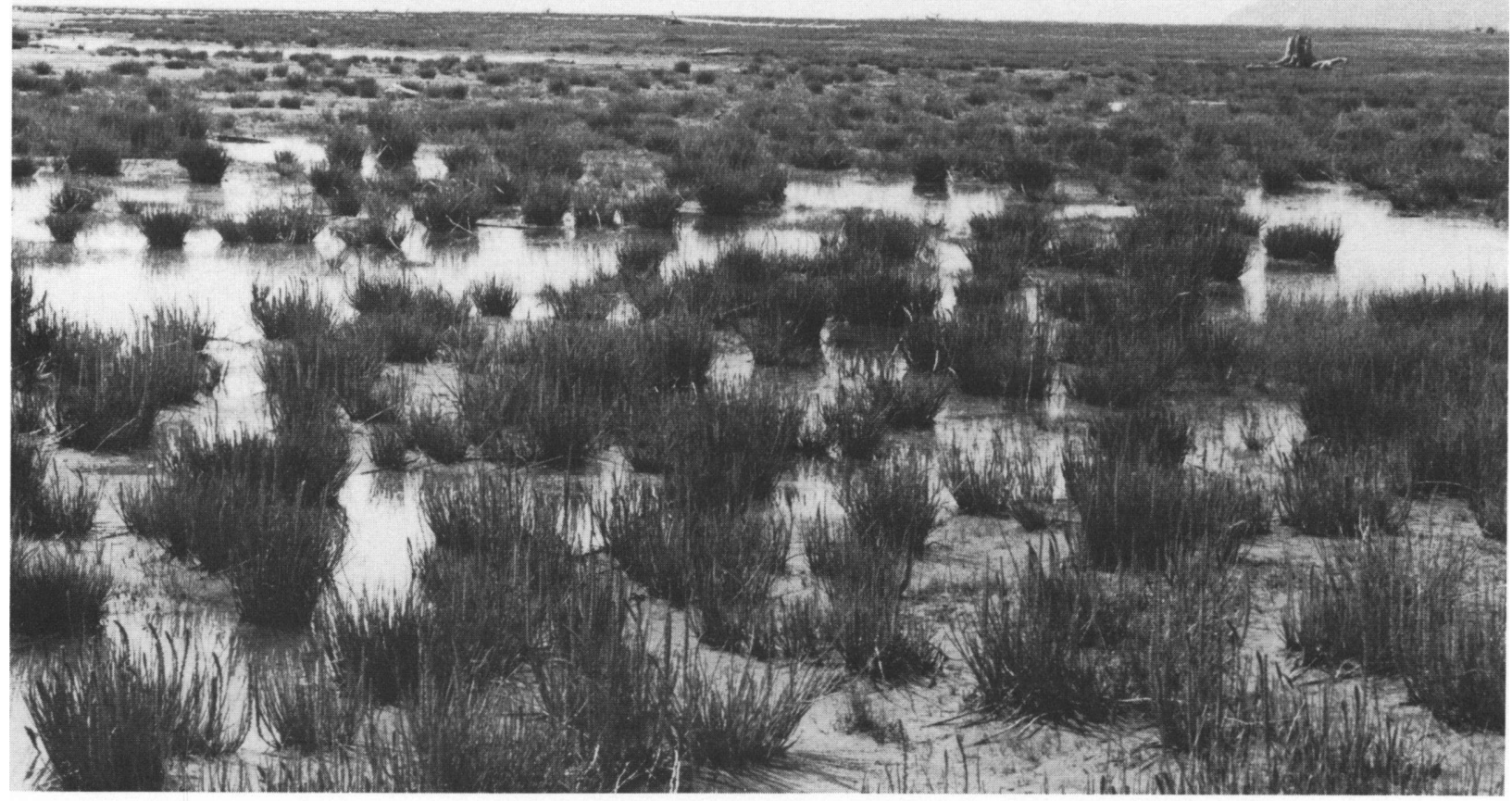

Plate 19.-Classification: SYSTEM Estuarine, SUBSYSTEM Intertidal, CLASS Emergent Wetland, sUBCLASS Persistent, DOMINANCE TYPE Triglochin maritimum, WATER REGIME Irregularly Flooded, WATER CHEMISTRY Mixohaline, soll Mineral. Subordinate plants include samphire (Salicornia europaea) and seaside plantain (Plantago maritima). This stand is located at the seaward edge of the irregularly flooded zone where it is inundated by most, but not all, high tides. Water depth is less than $5 \mathrm{~cm}$ ( 2 in). Slightly more elevated stands of Triglochin maritimum contain little or no standing water between periods of inundation. (Municipality of Anchorage, Alaska; June 1985; Photo by F. C. Golet) 


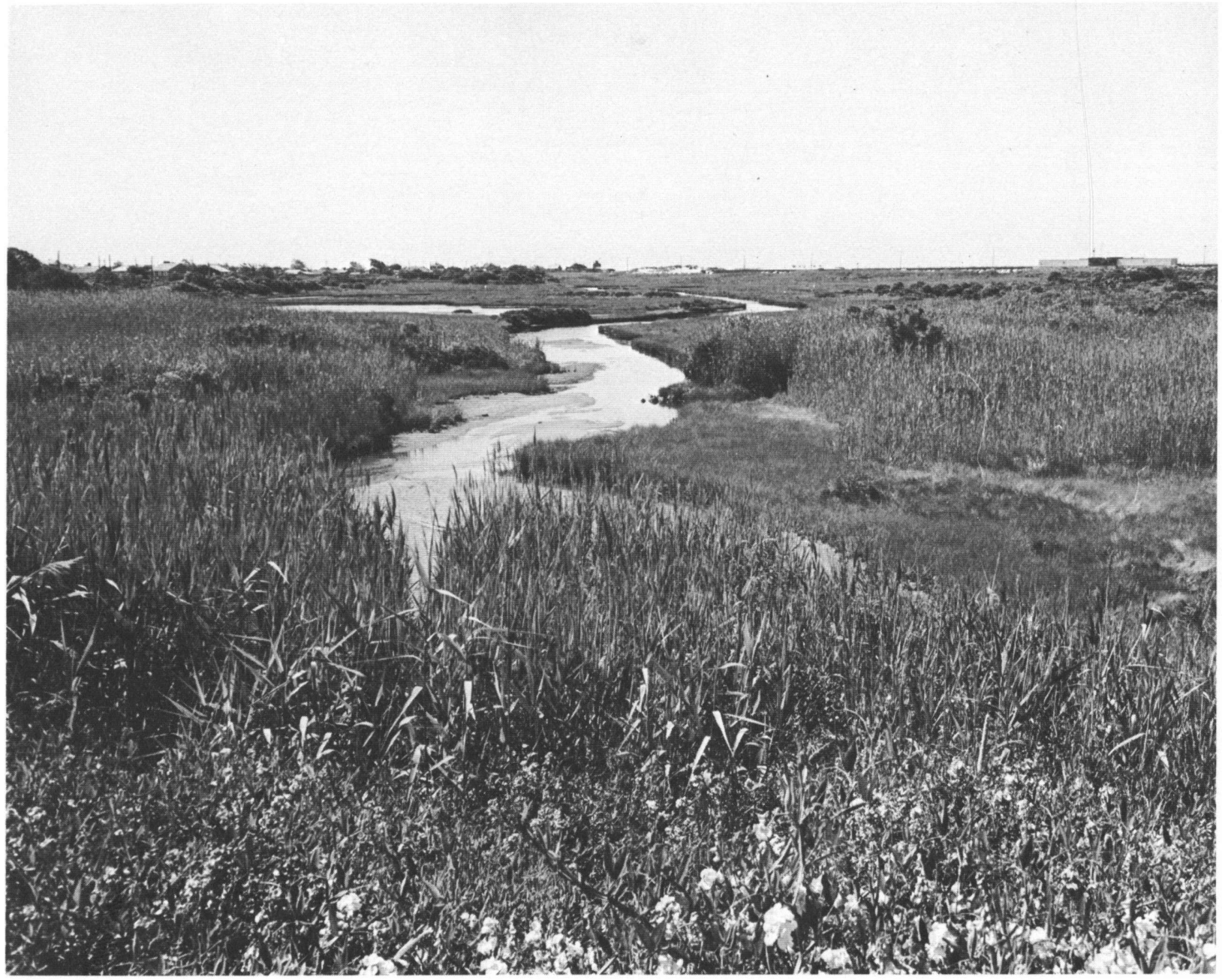

Plate 20.-Classification: SYSTEM Estuarine, SUBSYSTEM Intertidal, CLASS Emergent Wetland, sUBCLASs Persistent, DOMINANCE TYPE Phragmites australis, WATER REgIME Irregularly Flooded, WATER CHEMISTRY Mixohaline, soIL Mineral. Saltmeadow cordgrass (Spartina patens) and saltmarsh cordgrass (Spartina alterniflora) are subordinate species. (Washington County, Rhode Island; July 1977; Photo by F. C. Golet) 


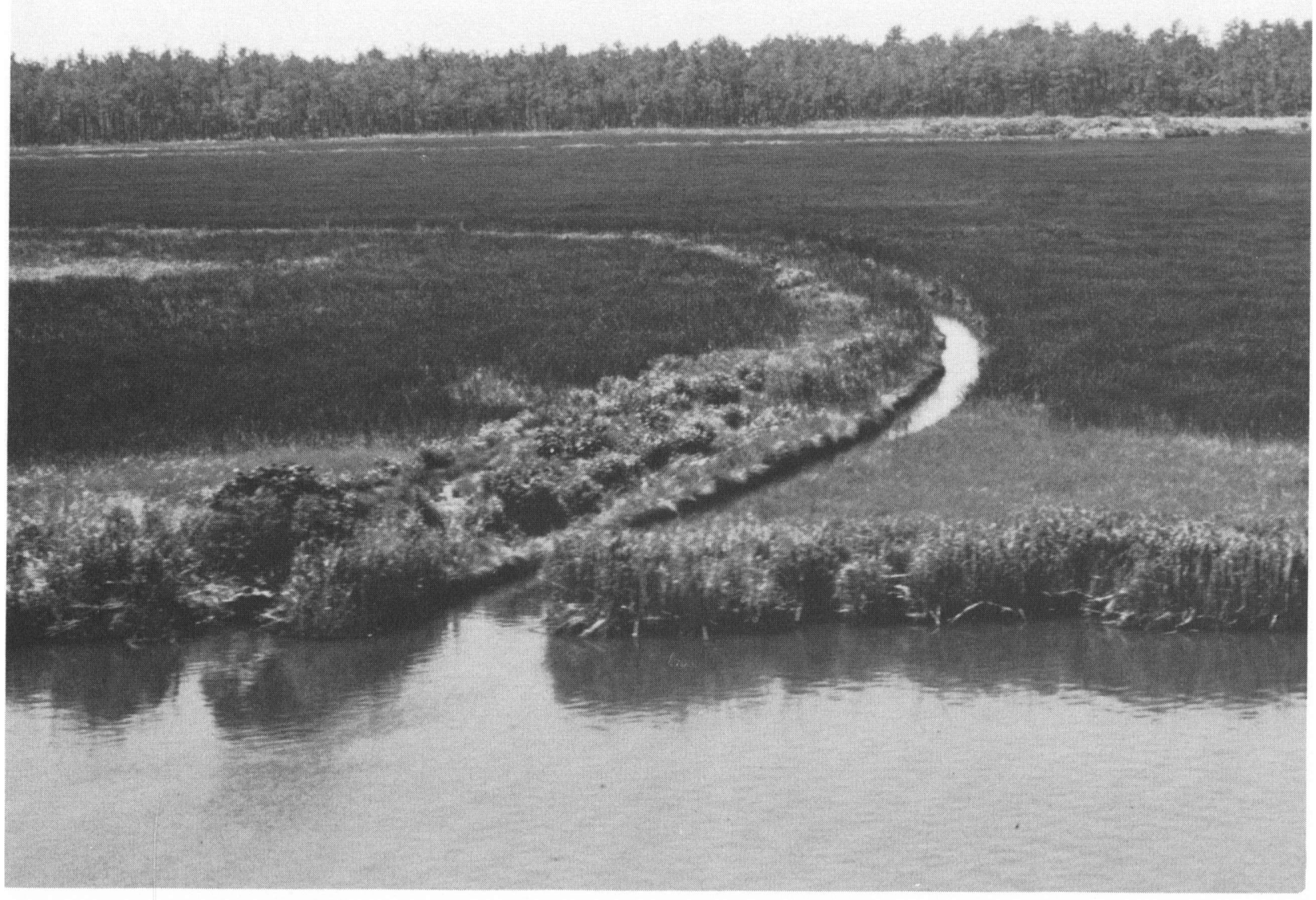

Plate 21.-Classification: SYSTEM Estuarine, SUBSYSTEM Intertidal, CLASS Emergent Wetland, sUBCLASS Persistent, DominaNCE TYPE Scirpus americanus, WATER REGIME Regularly Flooded, WATER CHEMISTRY Mixohaline, soIL Organic. Subordinate species include saltmeadow cordgrass (Spartina patens) and saltmarsh cordgrass (Spartina alterniflora); these appear as a fringe at the water's edge. (Dorchester County, Maryland; June 1974; Photo by V. Carter) 


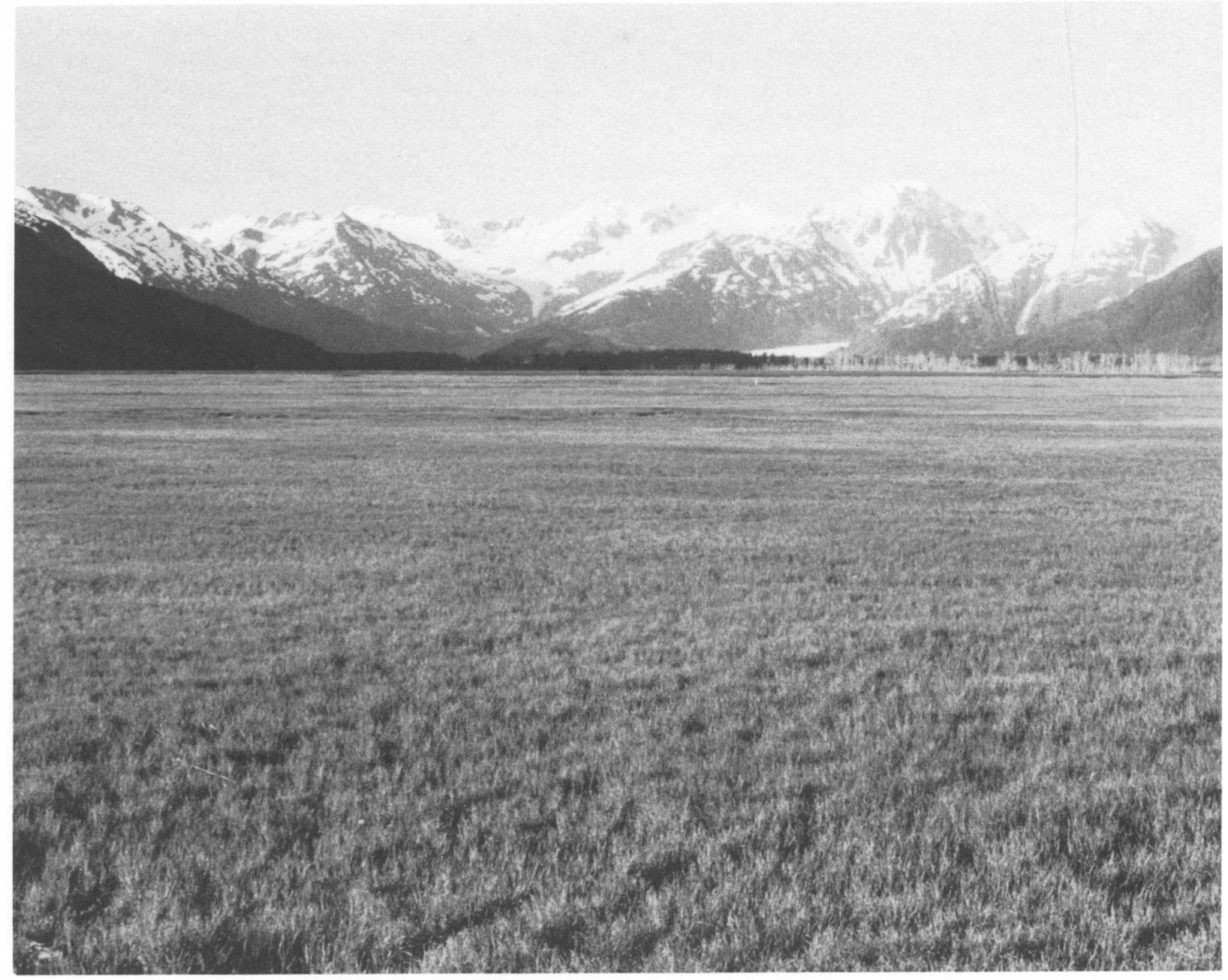

Plate 22.-Classification: SYSTEM Estuarine, SUBSYSTEM Intertidal, CLASS Emergent Wetland, sUBCLASS Persistent, DOMINANCE TYPE Carex lyngbyei, WATER REGIME Irregularly Flooded, WATER CHEMISTRY Oligohaline, soIL Mineral. Subordinate species include sedge (Carex pluriflora), silverweed (Potentilla anserina), arrow grass (Triglochin maritimum), and mare's tail (Hippuris tetraphylla). Located on the floodplain of a tidal river, this site receives freshwater runoff from the Chugach Mountains and the Twenty-mile Glacier (center background), and is also inundated by exceptionally high tides. Soil salinity during October 1985 was 3.0\% (Muncipality of Anchorage, Alaska; June 1985; Photo by F. C. Golet) 


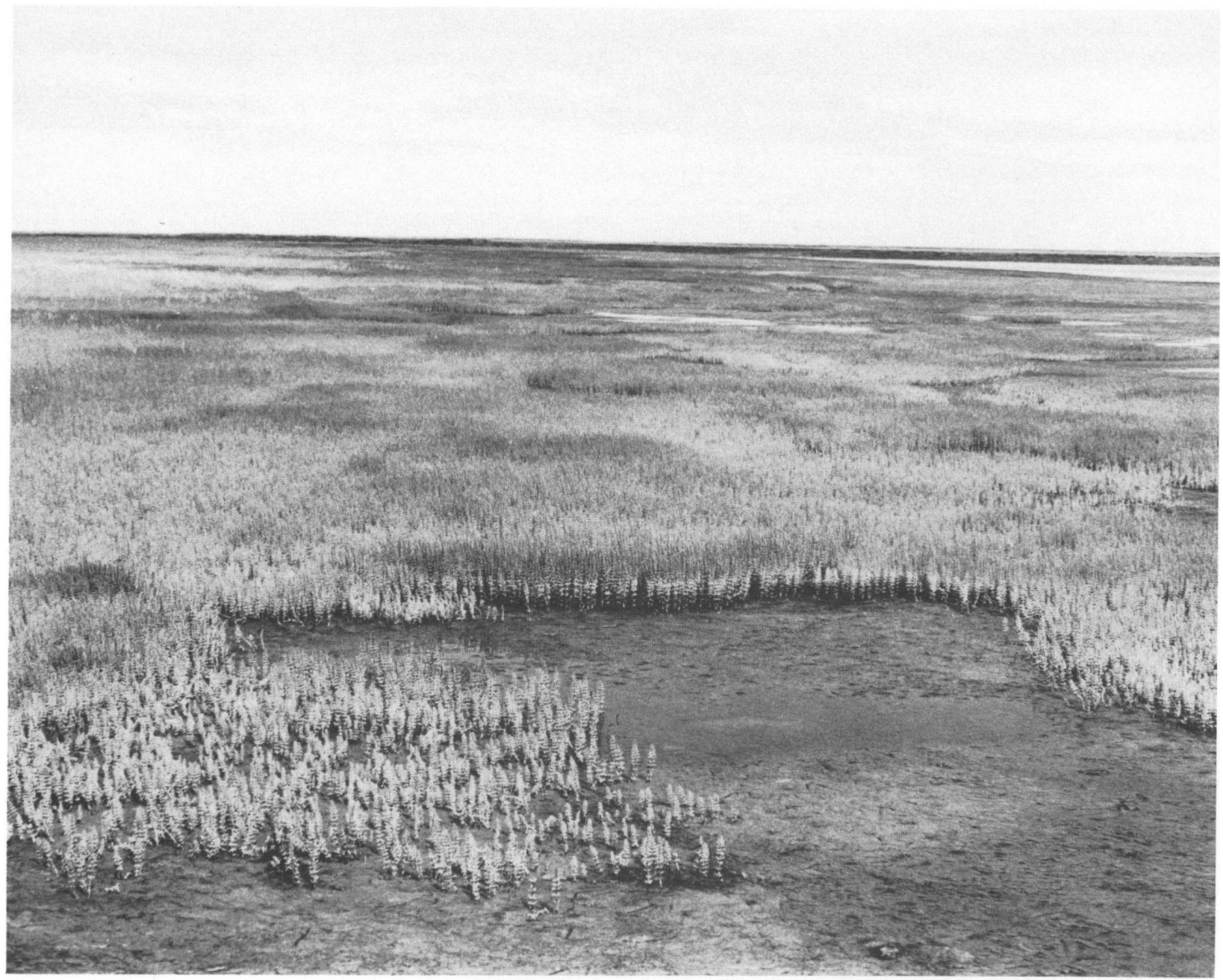

Plate 23.-Classification: SYSTEM Estuarine, SUBSYSTEM Intertidal, CLASS Emergent Wetland, sUBCLASS Nonpersistent, DOMINANCE TYPE Hippuris tetraphylla, WATER REGIME Regularly Flooded, WATER CHEMISTRY Mixohaline, soIL Mineral. This stand of mare's tail lies at the landward limit of the regularly flooded zone, where the substrate is covered with several centimeters of water at high tide. The Azun River, source of the tidal water, is just visible at the right-hand edge of the photo. (Mouth of Azun River, Yukon-Kuskokwim Delta, Alaska; July 1985; Photo by F. C. Golet) 

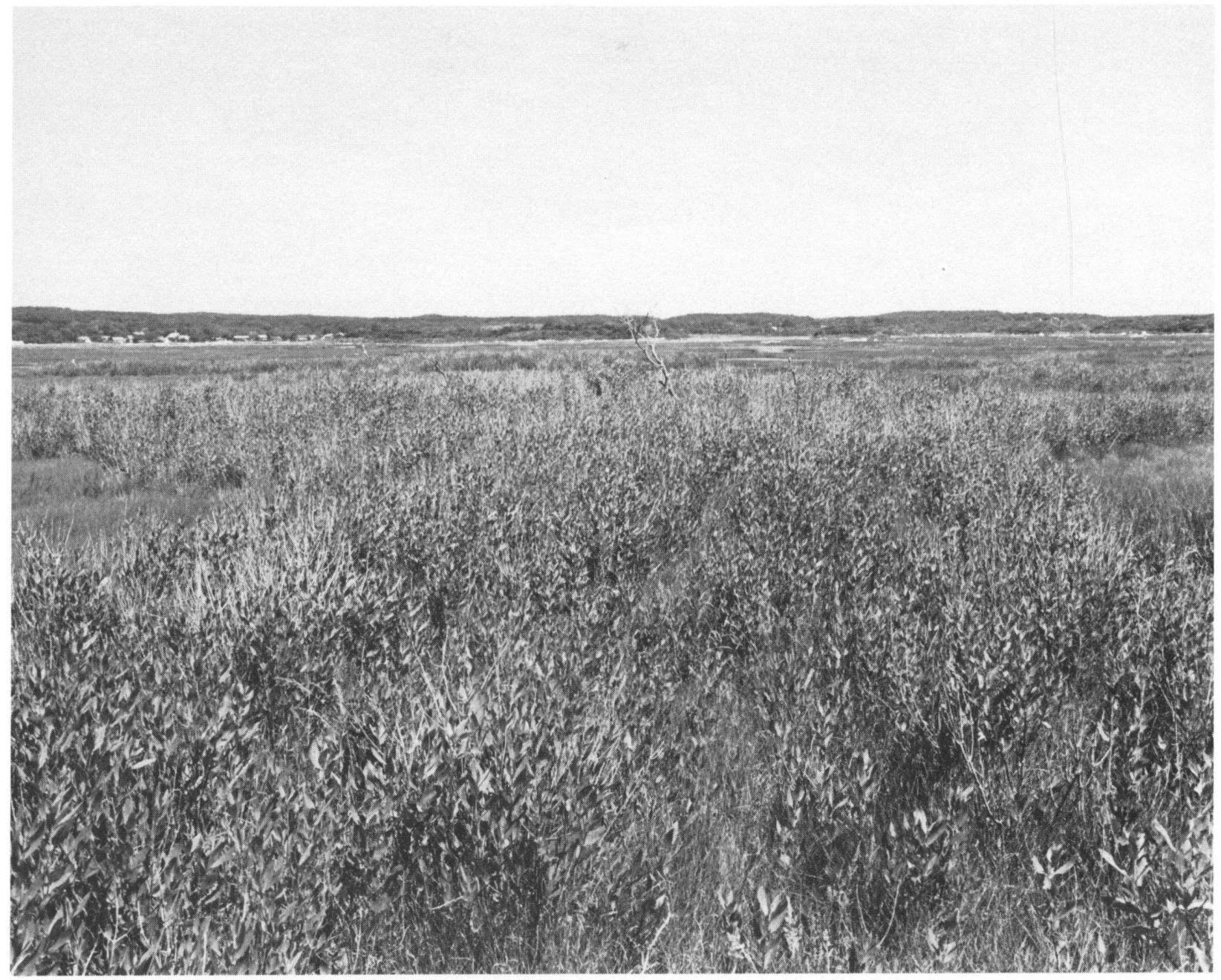

Plate 24.-Classification: SYSTEM Estuarine, sUBSYSTEM Intertidal, CLASs Scrub-Shrub Wetland, suBCLASS Broad-leaved Deciduous, DOMINANCE TYPE Iva frutescens, WATER REGIME Irregularly Flooded, WATER CHEMISTRY Mixohaline, soIL Mineral. Subordinate plants growing beneath the marsh elder are black grass (Juncus gerardii), salt grass (Distichlis spicata), and saltmeadow cordgrass (Spartina patens). This wetland lies toward the landward edge of an irregularly flooded persistent-emergent wetland dominated by saltmarsh cordgrass (Spartina alterniflora), saltmeadow cordgrass, and salt grass (background). (Washington County, Rhode Island; July 1977; Photo by F. C. Golet) 


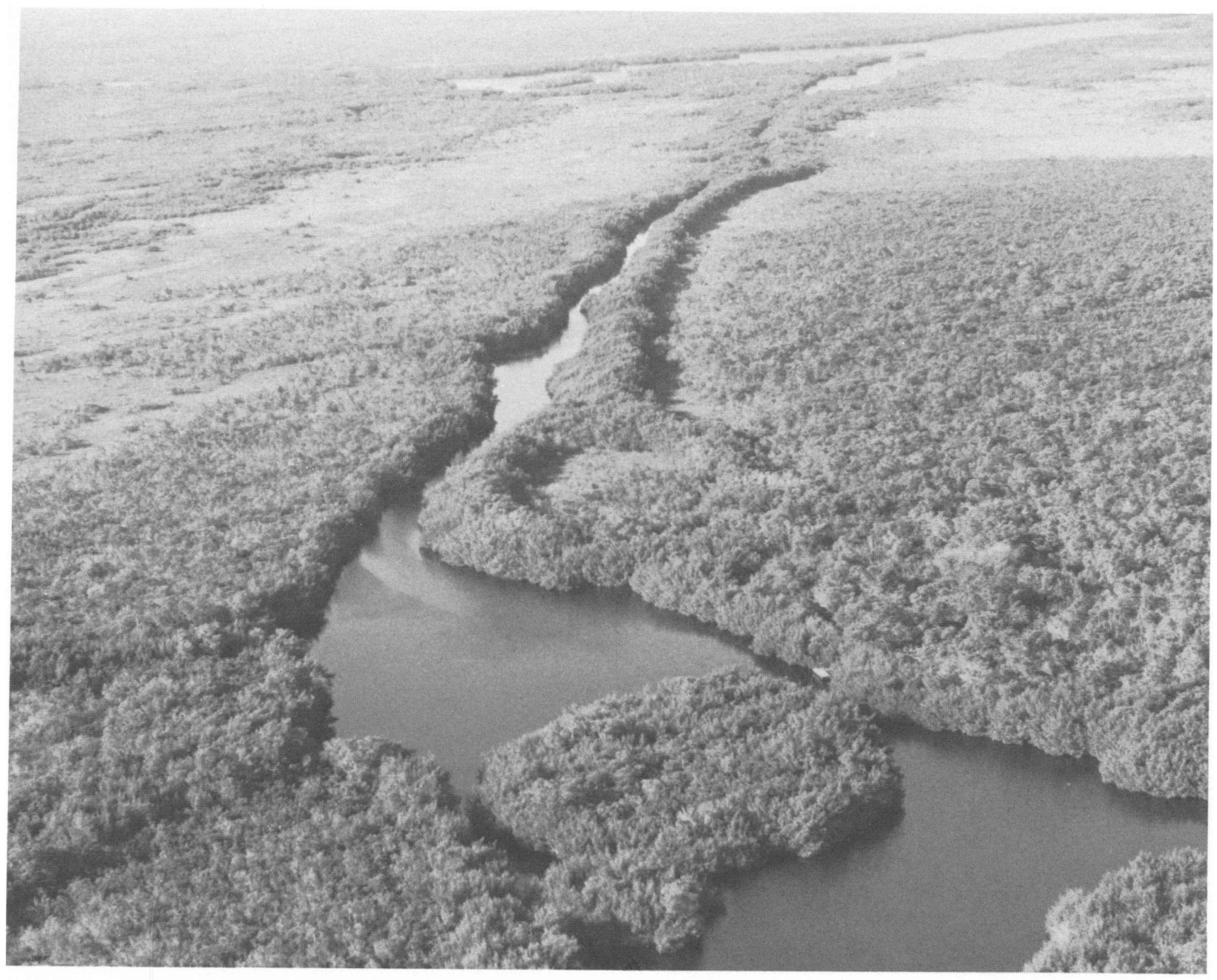

Plate 25.-Classification: SYSTEM Estuarine, SUBSYSTEM Intertidal, CLASS Scrub-Shrub Wetland, sUBCLASS Broad-leaved Evergreen, DOMINANCE TYPE Rhizophora mangle, WATER REGIMES Regularly Flooded (along waterways) and Irregularly Flooded (at some distance from waterways), WATER CHEMISTRY Oligohaline, soIL Organic. This mangrove swamp is located in the southern part of the Florida Everglades. (Dade County, Florida; December 1975; Photo by V. Carter) 


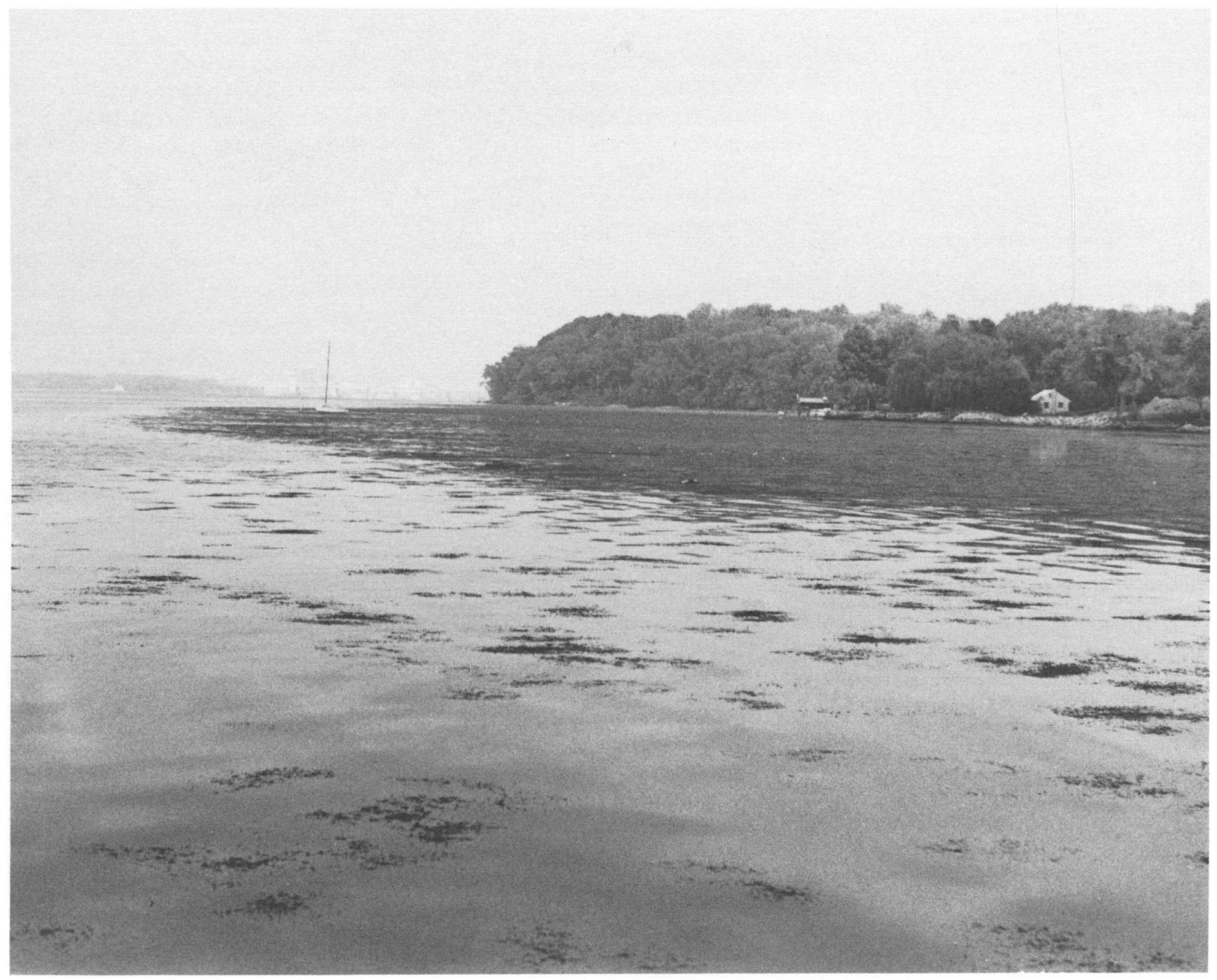

Plate 26.-Classification: SYstem Riverine, SUBSystem Tidal, Class Aquatic Bed, subClass Rooted Vascular, DominaNCE TYPE Myriophyllum spicatum-Hydrilla verticillata-Heteranthera dubia, WATER REGIME Permanently Flooded-Tidal, WATER CHEMISTRY Fresh-Circumneutral. (Prince Georges County, Maryland; October 1985; Photo by V. Carter) 


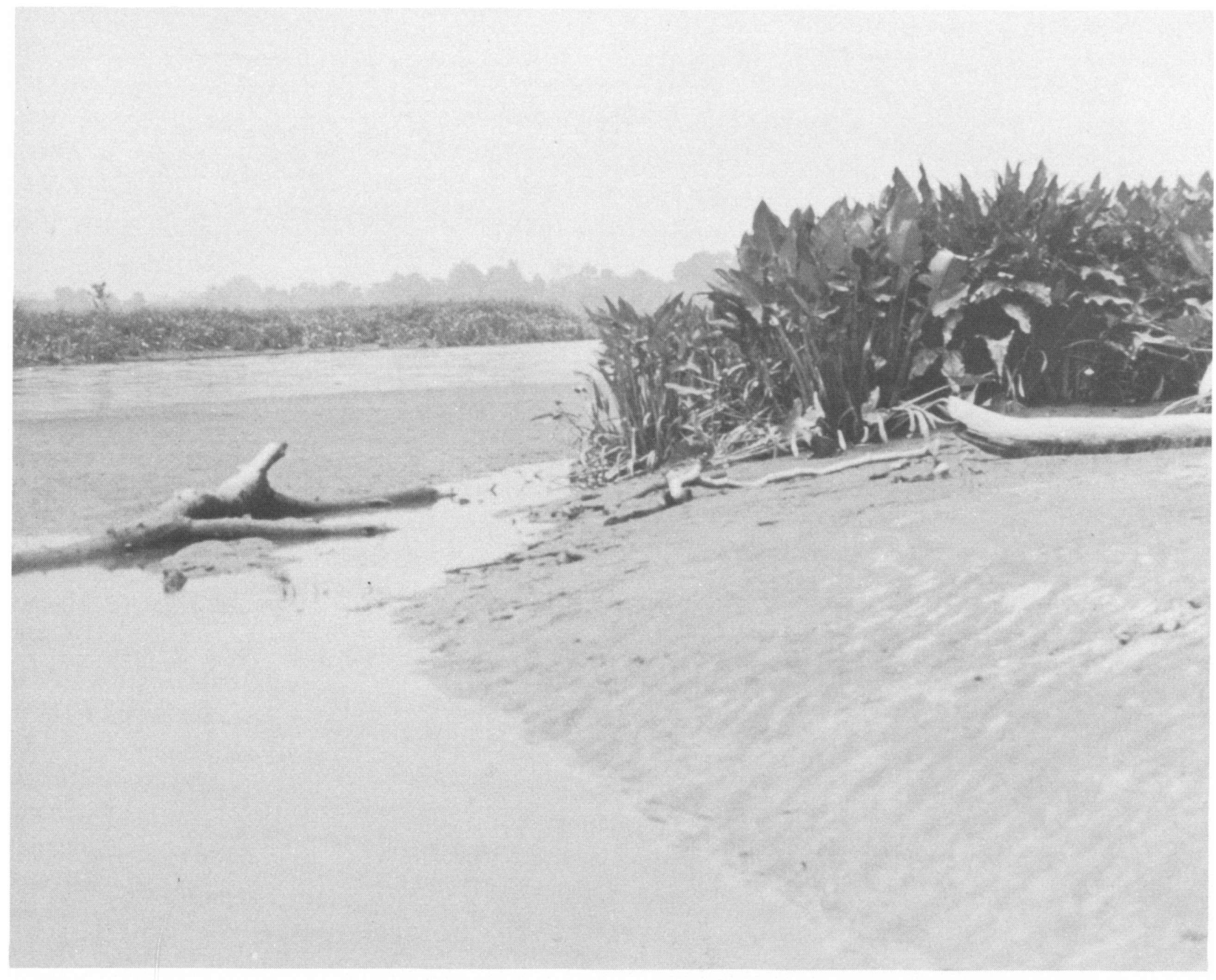

Plate 27.-Two habitats are shown here. Classification of nonvegetated zone: SYSTEM Riverine, sUBSYSTEM Tidal, CLASS Unconsolidated Shore, sUBCLASS Mud, WATER REGIME Regularly Flooded, WATER CHEMISTRY Fresh-Circumneutral. Classification of vegetated zone: SYSTEM Riverine, SUBSYSTEM Tidal, CLASS Emergent Wetland, SUBCLASS Nonpersistent, DOMINANCE TYPE Peltandra virginica, WATER REgIME Regularly Flooded, WATER CHEMISTRY Fresh-Circumneutral, soil Mineral. The photo was taken at low tide. (Cecil County, Maryland; July 1972; Photo by V. Carter) 


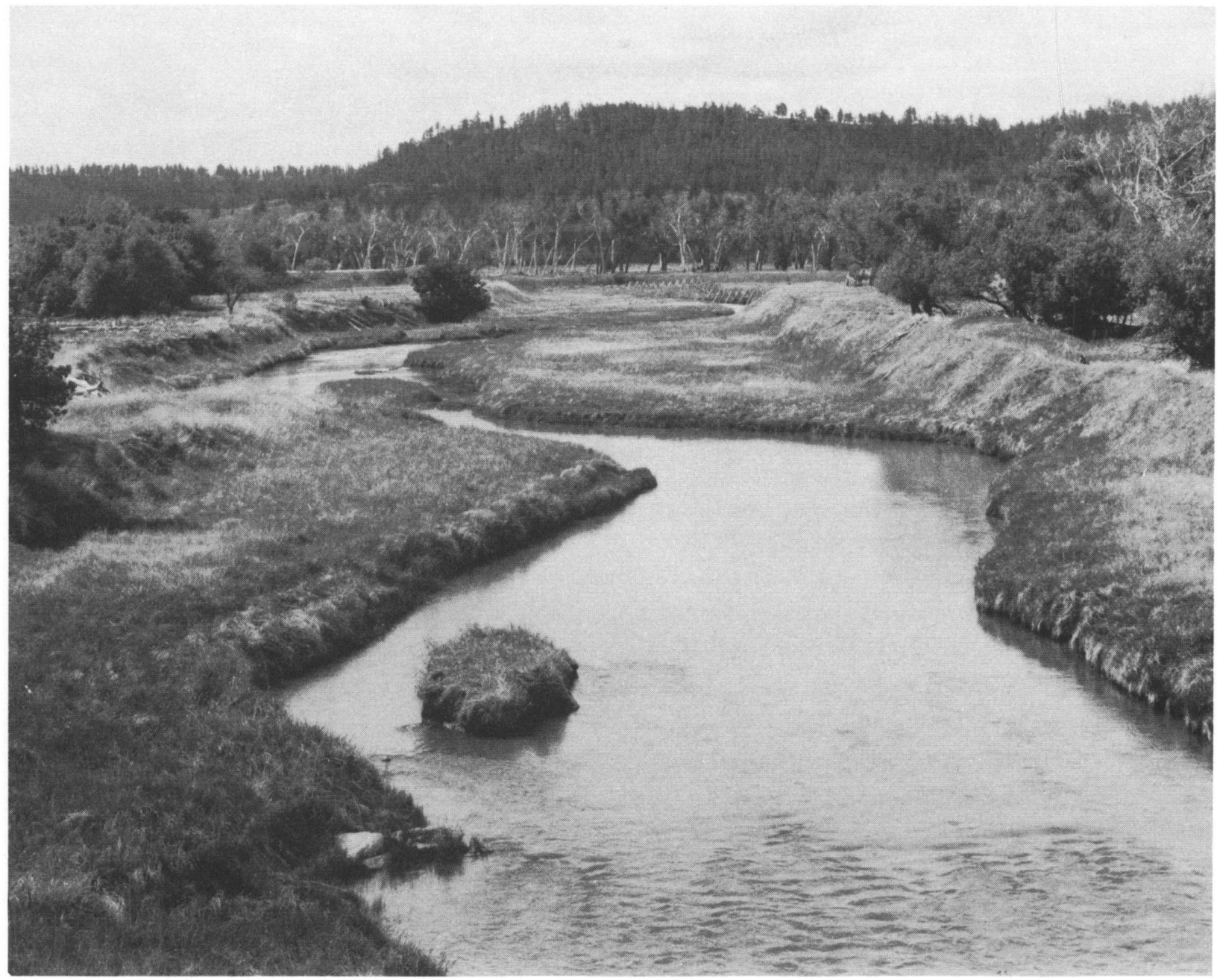

Plate 28.-Classification: SYSTEM Riverine, SUBSYSTEm Lower Perennial, CLASS Unconsolidated Bottom, suBCLASS Cobble-Gravel, WATER Regime Permanently Flooded, water Chemistry Fresh. The channel bottom is composed primarily of gravel and sand. The stream meanders through a grassy annual floodplain which is flanked by a more elevated floodplain supporting cottonwoods (Populus deltoides). (Crook County, Wyoming; May 1985; Photo by F. C. Golet) 


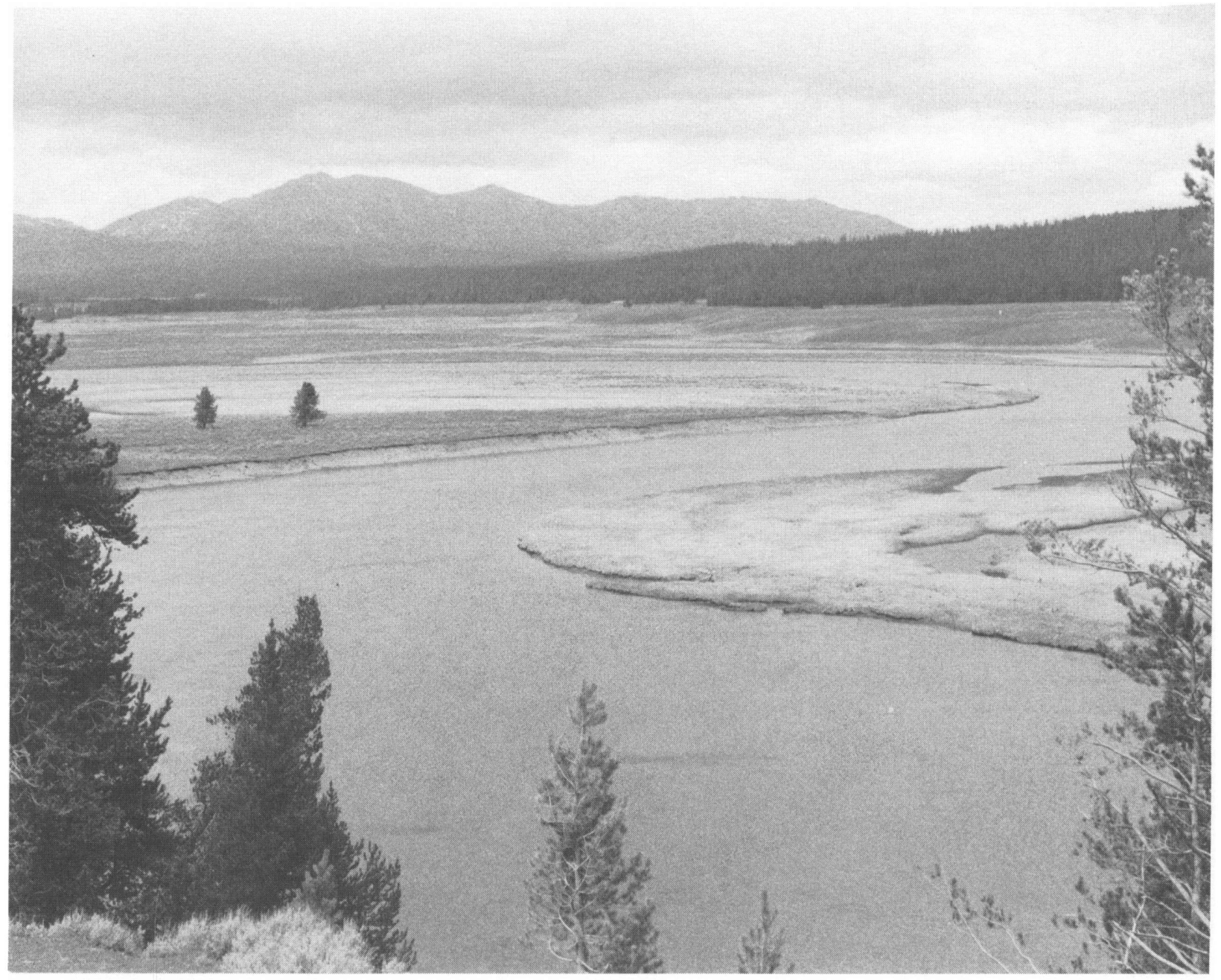

Plate 29.-Classification: system Riverine, SUBSYstem Lower Perennial, CLASS Unconsolidated Bottom, SUBCLASs Sand, wateR REGIMe Permanently Flooded, WATER CHEMISTRY Fresh. Channel meanders, a typical feature of lower perennial streams, are especially well developed along this section of the Yellowstone River. (Yellowstone National Park, Park County, Wyoming; May 1985; Photo by F. C. Golet) 


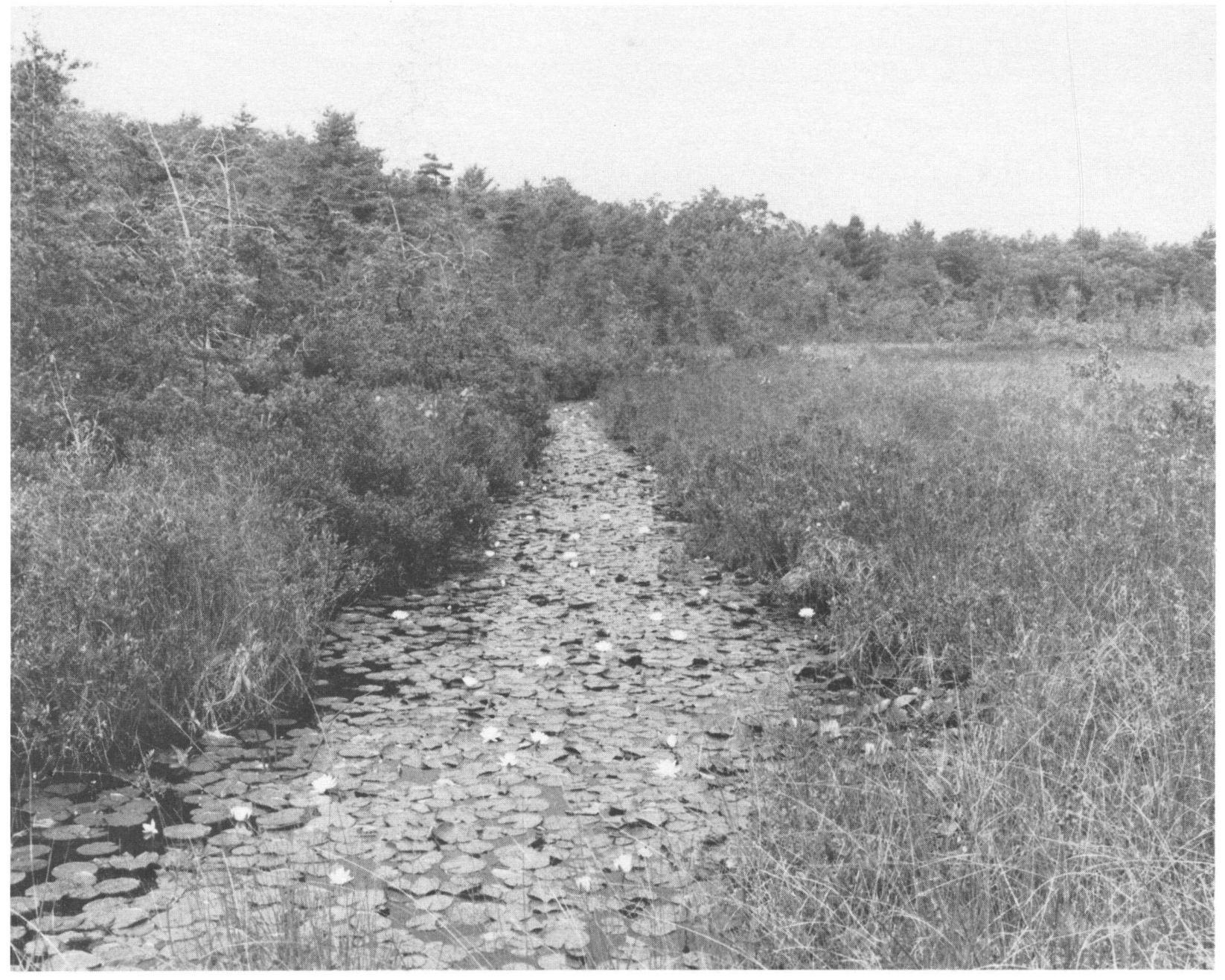

Plate 30.-Classification: system Riverine, subsystem Lower Perennial, class Aquatic Bed, subclass Rooted Vascular, Dominance TYPE Nymphaea odorata, WATER REgIME Permanently Flooded, WATER CHEMISTRY Fresh-Circumneutral, SPECIAL MODIFIER Excavated. This channel was dug by man in an unsuccessful attempt to drain the wetland. Plants in the Palustrine wetland bordering the channel include sedge (Carex lasiocarpa), sweet gale (Myrica gale), leatherleaf (Chamaedaphne calyculata), and Atlantic white cedar (Chamaecyparis thyoides). (Washington County, Rhode Island; July 1977; Photo by F. C. Golet) 


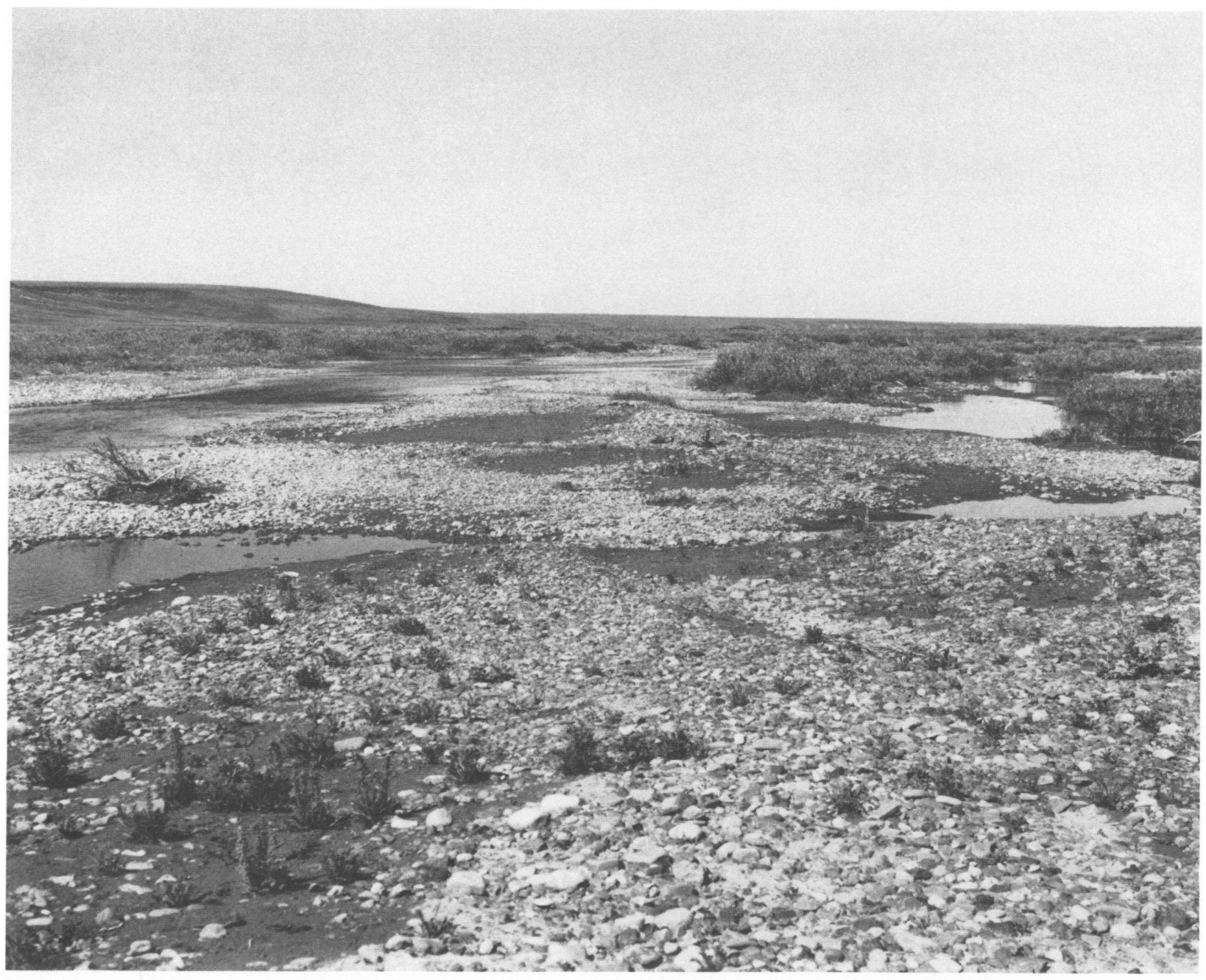

Plate 31.-Classification: System Riverine, subsystem Lower Perennial, Class Unconsolidated Shore, SUbCLASs Cobble-Gravel, WATER REgime Temporarily Flooded, WATER ChEMISTRY Fresh. Feltleaf willow (Salix alaxensis) grows along the edge of the stream. The entire channel is flooded for only a few weeks after snowmelt each year. (Kavik River, North Slope Borough, Alaska; July 1985; Photo by F. C. Golet) 


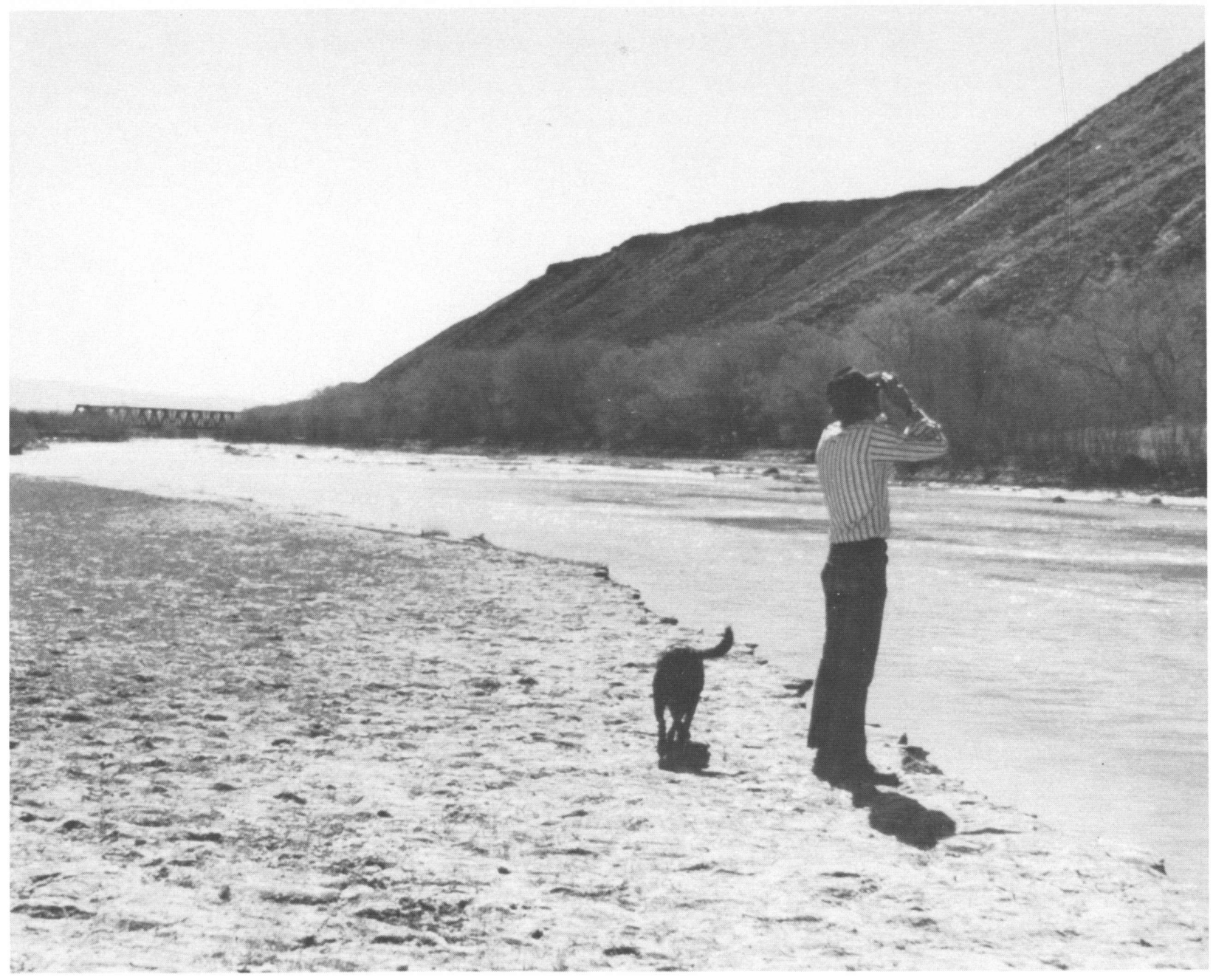

Plate 32.-Classification: System Riverine, subsystem Lower Perennial, Class Unconsolidated Shore, subClass Sand, wateR REgime Seasonally Flooded, WATER Chemistry Mixosaline, soll Mineral. Young tamarisk (Tamarix gallica) plants are scattered over this sand flat. (Socorro County, New Mexico; April 1978; Photo by P. B. Reed) 


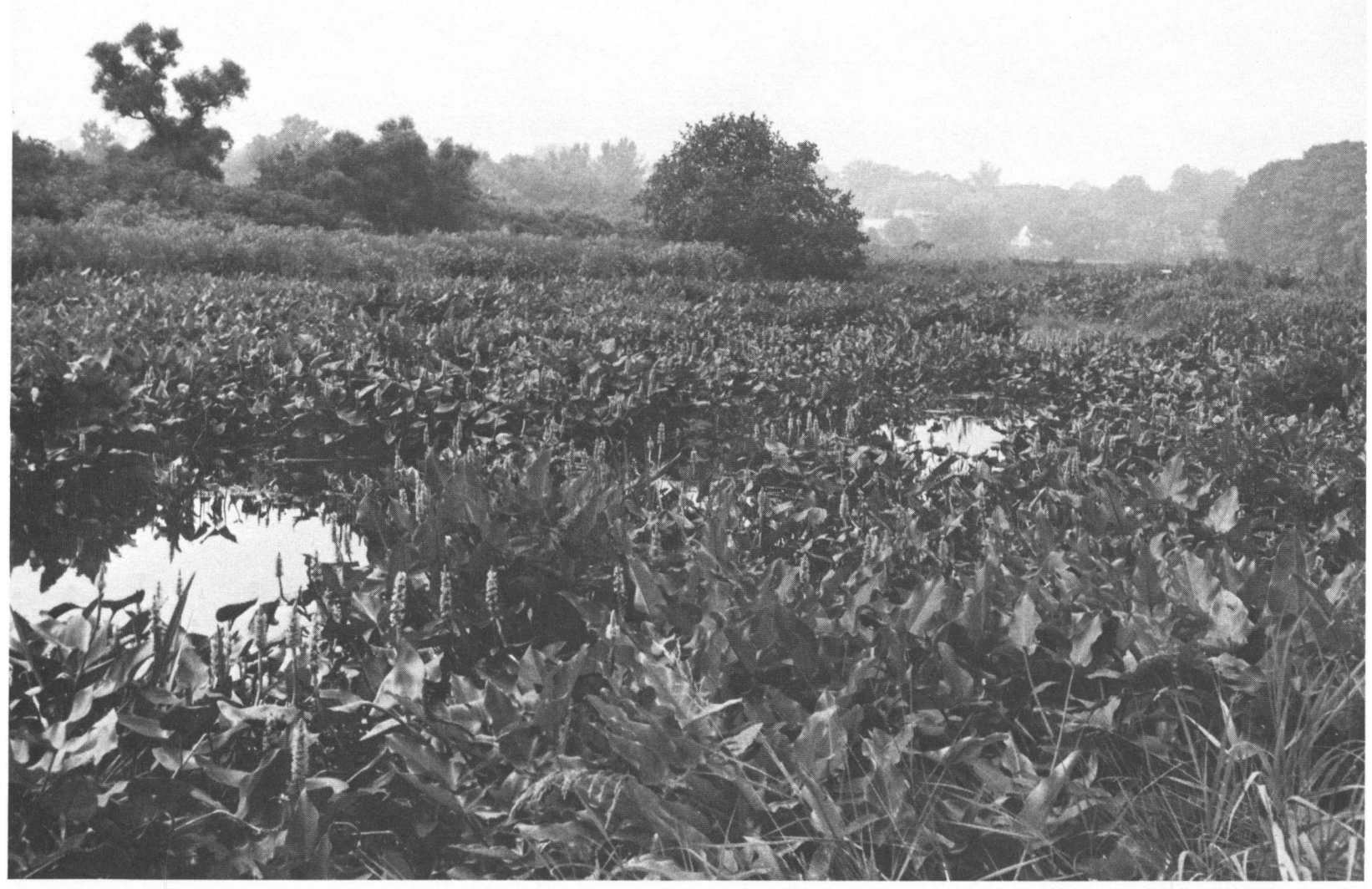

Plate 33.-Classification: SYstem Riverine, subsystem Lower Perennial, CLASs Emergent Wetland, subCLass Nonpersistent, DOMINANCE TYPE Peltandra virginica-Pontederia cordata, WATER REGIME Semipermanently Flooded, WATER CHEMISTRY FreshCircumneutral, solL Mineral. This wetland lies in a bay of the Chicopee River. (Hampden County, Massachusetts; July 1970; Photo by R. C. Smardon) 


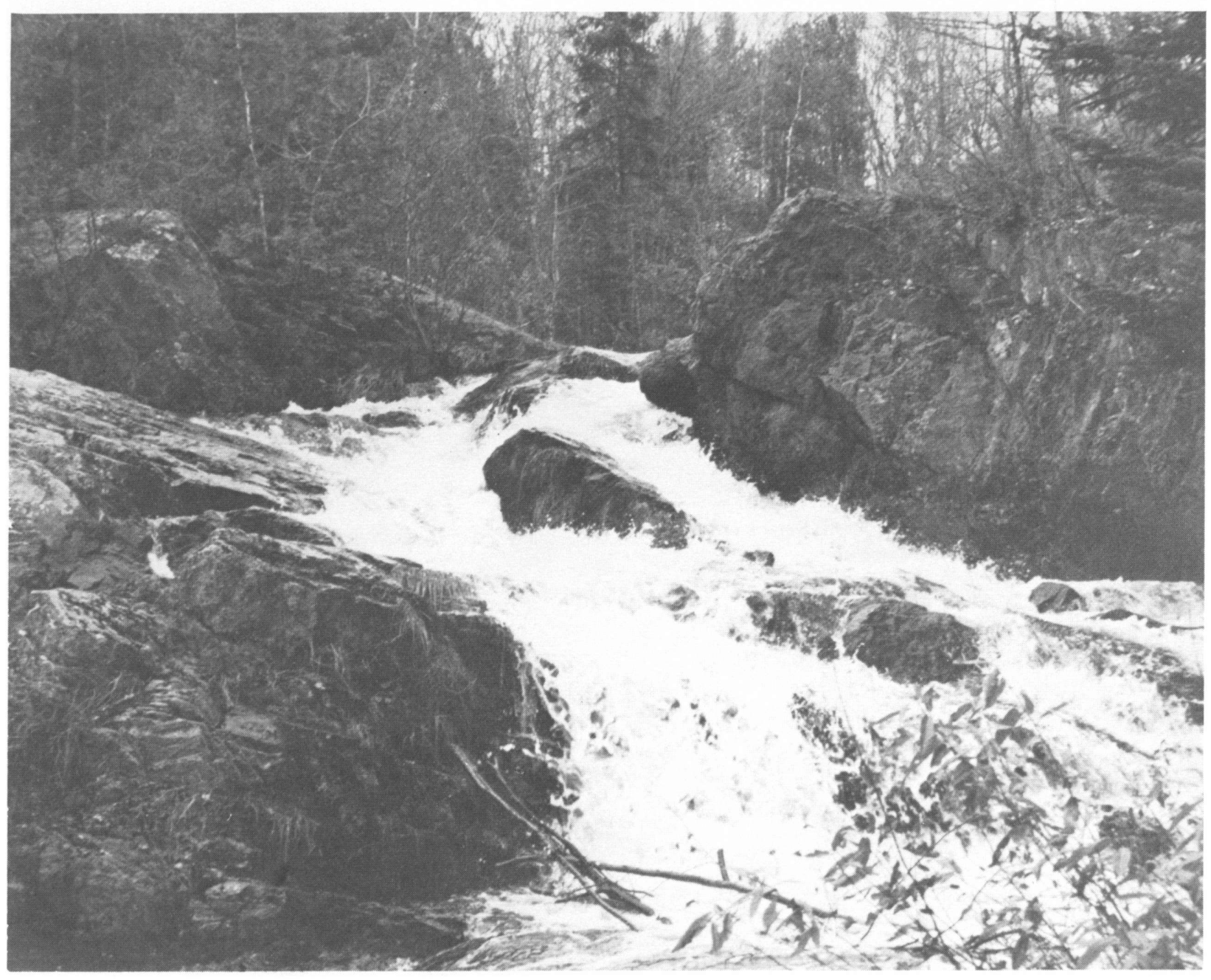

Plate 34.-Two habitats are shown here. Classification of channel: SYSTEM Riverine, sUBSYSTEM Upper Perennial, CLASS Rock Bottom, subclass Bedrock, WATER Regime Permanently Flooded, WATER ChEmistry Fresh. Classification of shore: system Riverine, subsystem Upper Perennial, Class Rocky Shore, subclass Bedrock, water Regime Seasonally Flooded, water CHEMistry Fresh. (Penobscot County, Maine; October 1977; Photo by R. W. Tiner) 


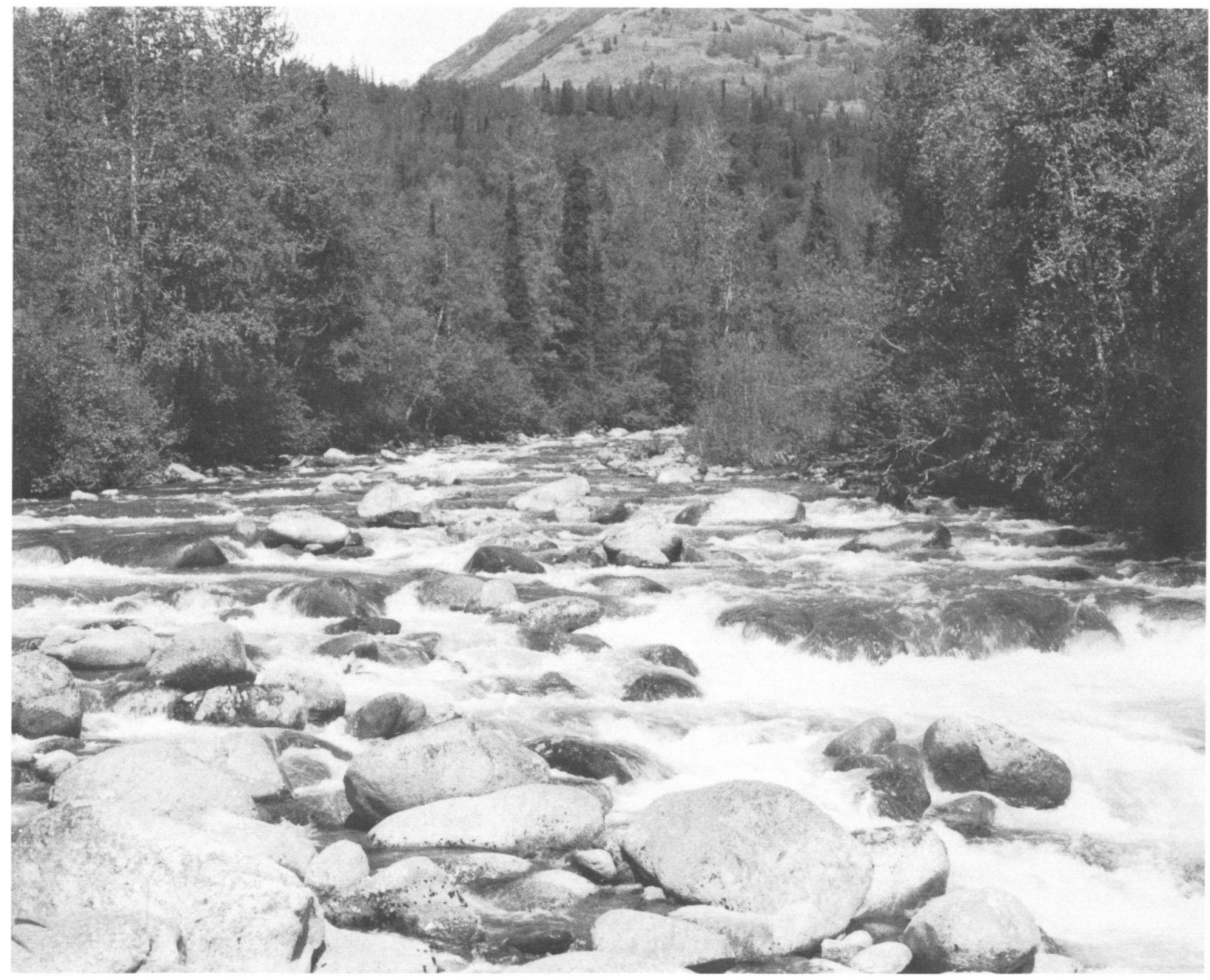

Plate 35.-Classification: SYSTEM Riverine, sUbSYSTEM Upper Perennial, CLASS Rock Bottom, SUBCLASS Rubble, waTER REGIME Permanently Flooded, WATER CHEMISTRY Fresh. Many of the boulders in this river exceed $1 \mathrm{~m}(3.3 \mathrm{ft})$ in diameter. (MatanuskaSusitna Borough, Alaska; June 1985; Photo by F. C. Golet) 


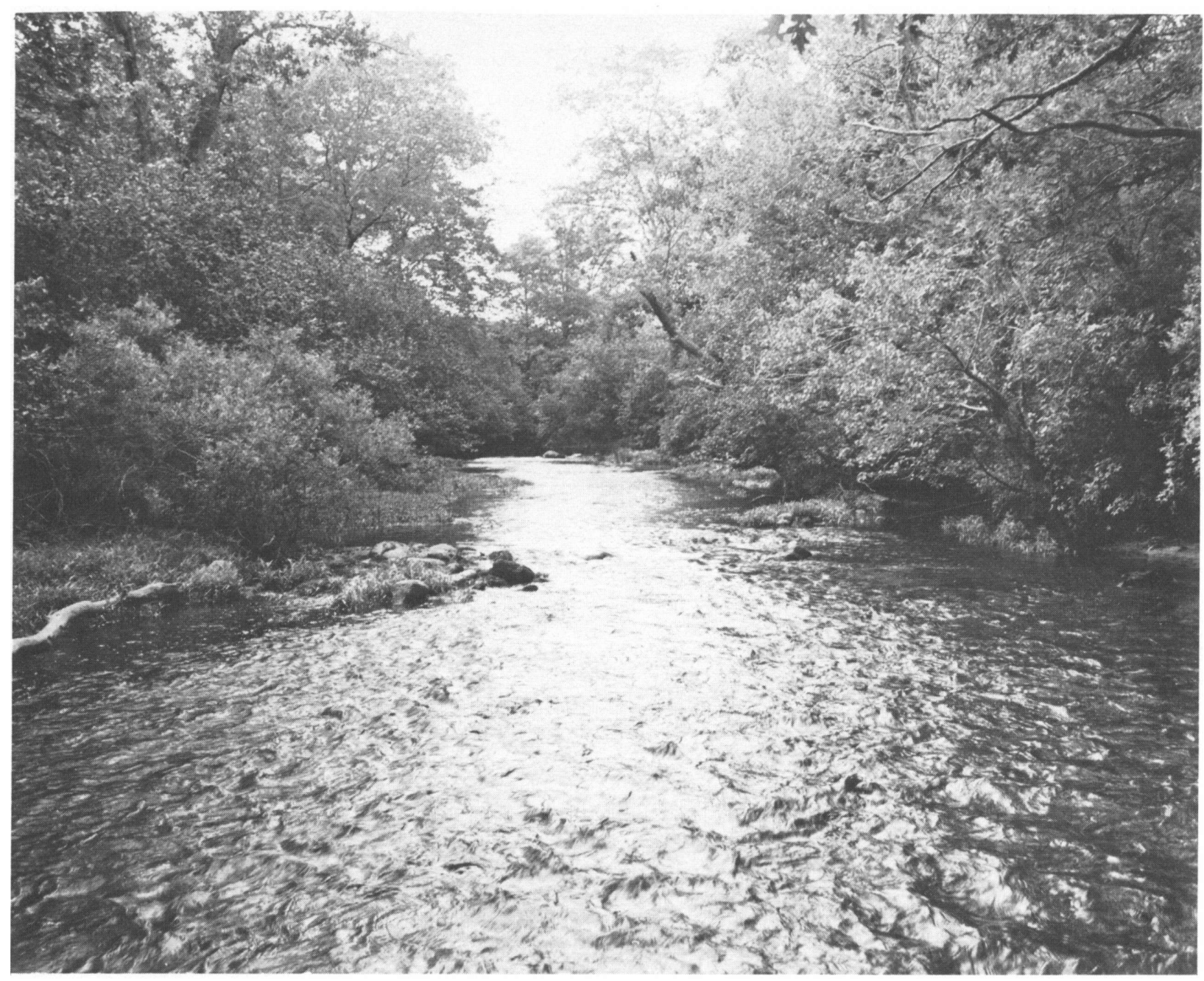

Plate 36.-Classification: SYSTEM Riverine, subsystem Upper Perennial, CLASs Unconsolidated Bottom, sUBCLASs Cobble-Gravel, WATER Regime Permanently Flooded, WATER Chemistry Fresh-Circumneutral. (Washington County, Rhode Island; July 1977; Photo by F. C. Golet) 


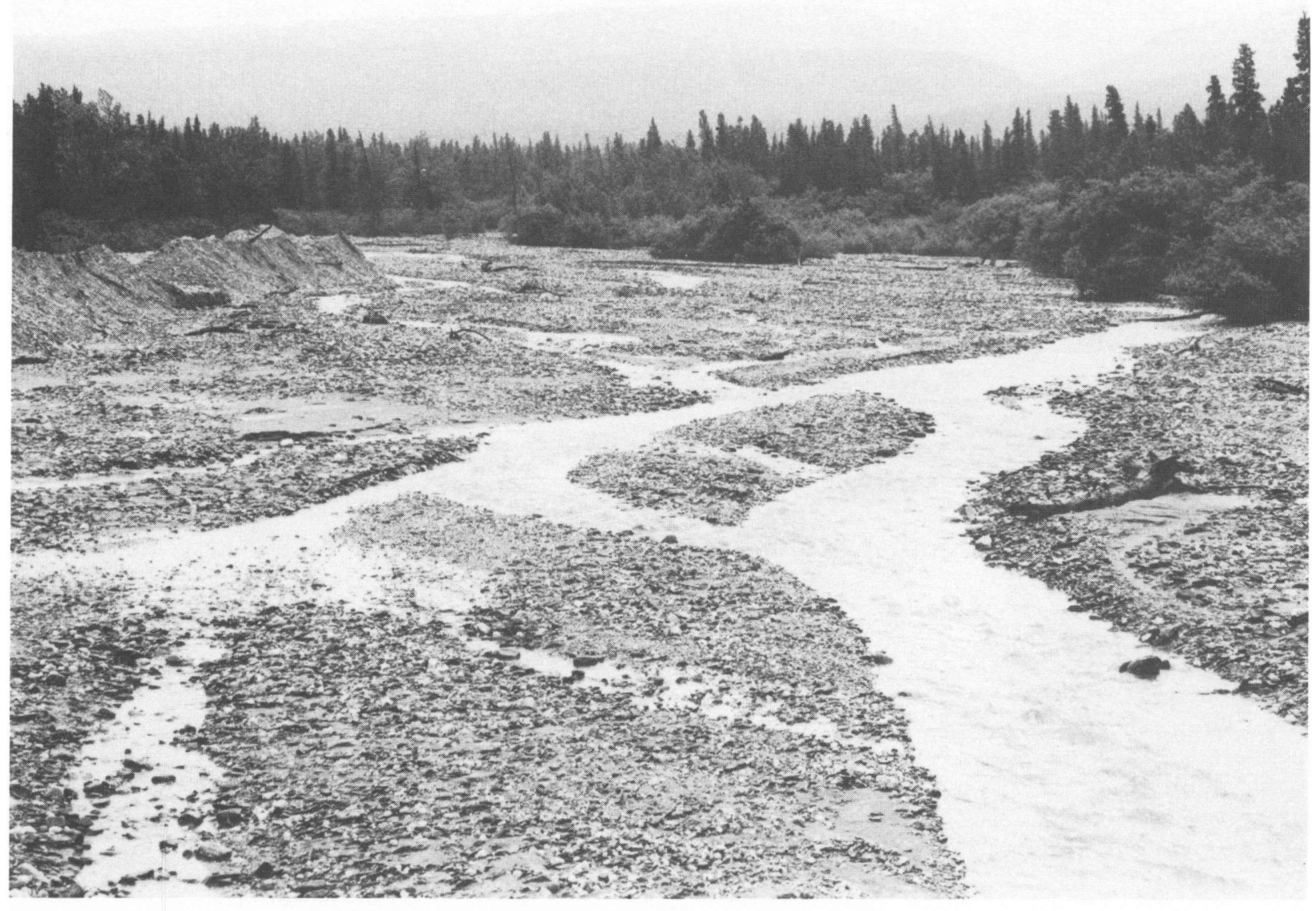

Plate 37.-Classification: SYSTEm Riverine, subSYstem Upper Perennial, CLASs Unconsolidated Shore, SUBCLASs Cobble-Gravel, WATER REgIME Temporarily Flooded, WATER CHEMISTRY Fresh. This high-gradient mountain stream arises in the Alaska Range. The gravel piled at the left-hand edge of the photo had accumulated in the channel during flood stage and was bulldozed to its present position to prevent flooding of a highway just downstream. (Fairbanks North Star Borough, Alaska; July 1985; Photo by F. C. Golet) 


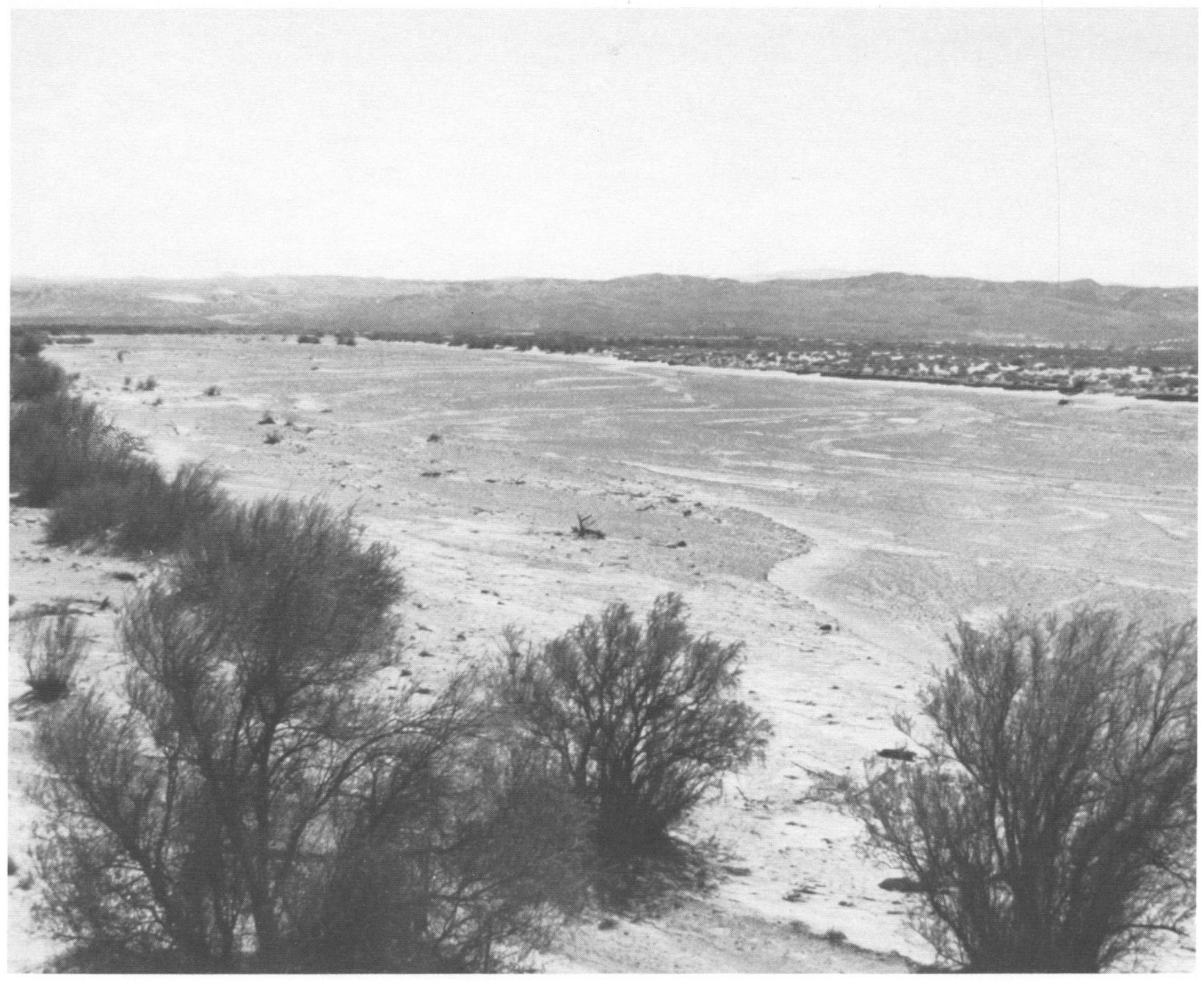

Plate 38.-Classification: SYSTEm Riverine, sUbSYSTEm Intermittent, CLASS Streambed, SUBCLASS Sand, WATER REGIME Intermittently Flooded, WATER CHEMISTRY Mixosaline. The average annual discharge for this river, the Rio Salado, is $14.6 \mathrm{hm}^{3} / \mathrm{yr}$ (11,880 acre-ft/yr). (Socorro County, New Mexico; April 1978; Photo by P. B. Reed) 


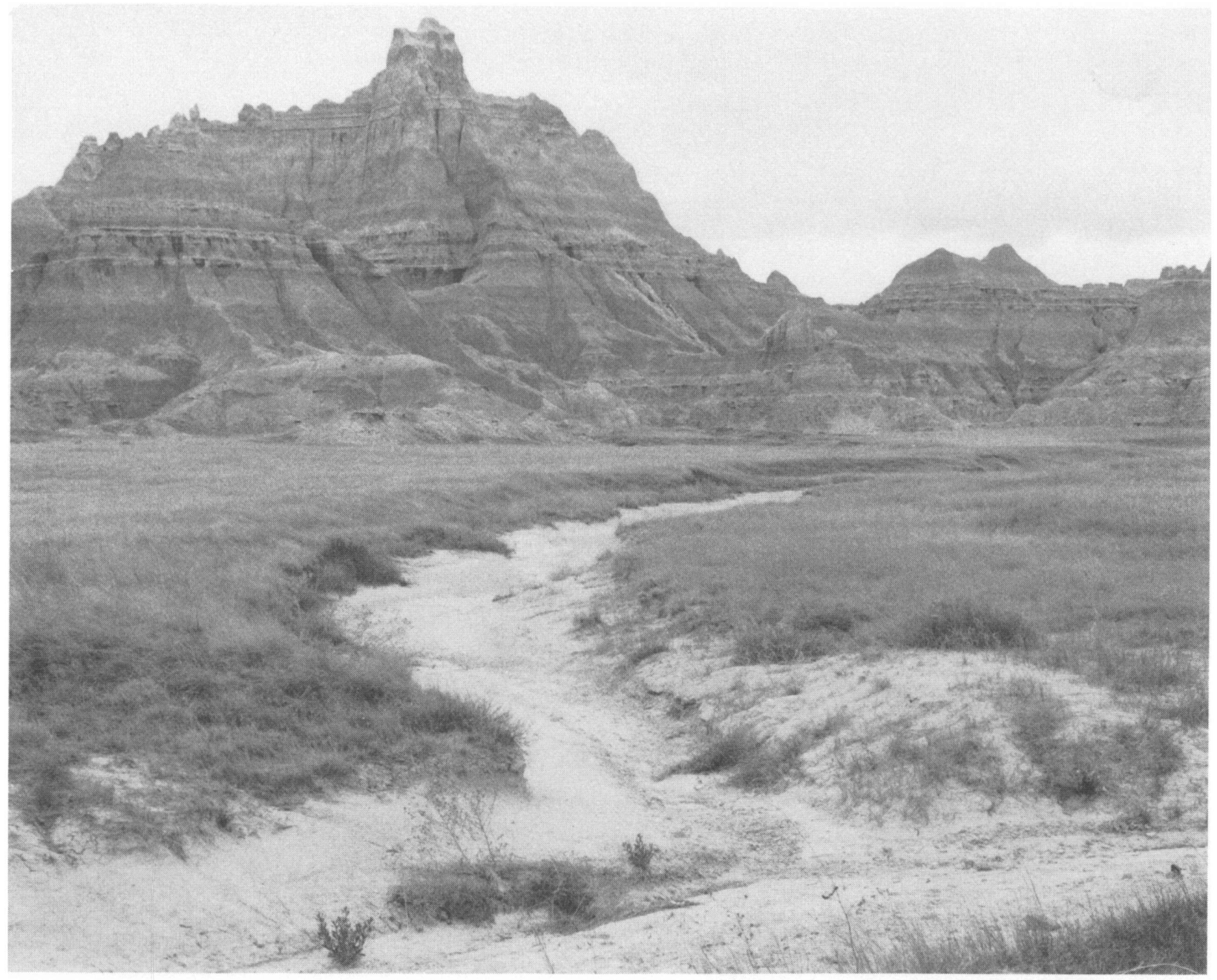

Plate 39.-Classification: SYSTEM Riverine, SUBSYSTEm Intermittent, CLASS Streambed, SUbCLASS Mud, WATER REGIME Intermittently Flooded. Streambeds such as this are common throughout the arid West. They carry water for brief periods after snowmelt and following rainstorms which are irregular and unpredictable in occurrence. (Badlands National Monument, Jackson County, South Dakota; May 1985; Photo by F. C. Golet) 


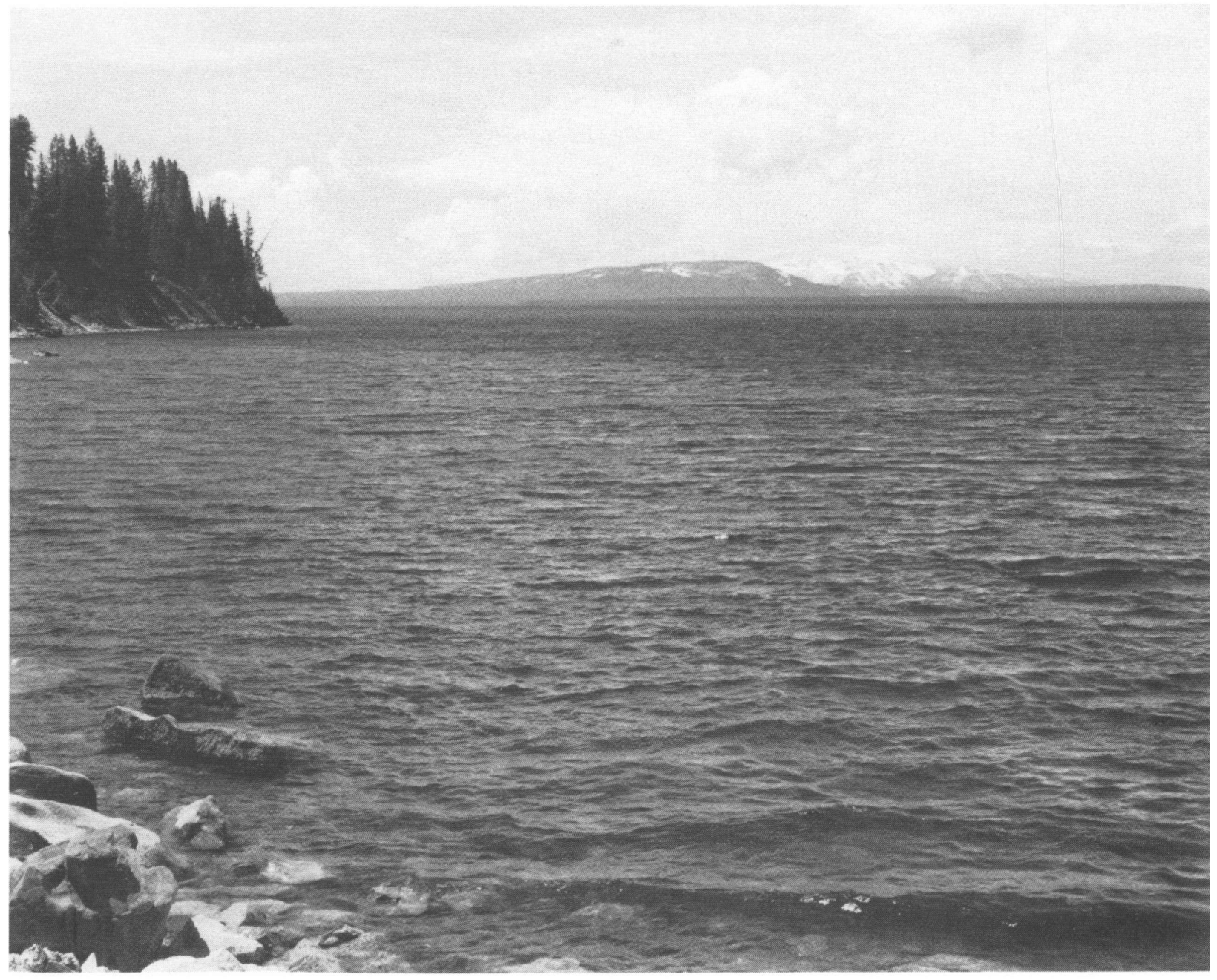

Plate 40.-Classification: SYSTEM Lacustrine, SUBSYSTEM Limnetic, CLASS Unconsolidated Bottom, SUBCLASS Mud, WATER REGIME Permanently Flooded, WATER CHEMISTRY Fresh. In the narrow Littoral zone of Yellowstone Lake, where water is less than 2 $\mathrm{m}(6.6 \mathrm{ft})$ deep, the bottom consists primarily of gravel and sand. (Yellowstone National Park, Teton County, Wyoming; May 1985; Photo by F. C. Golet) 


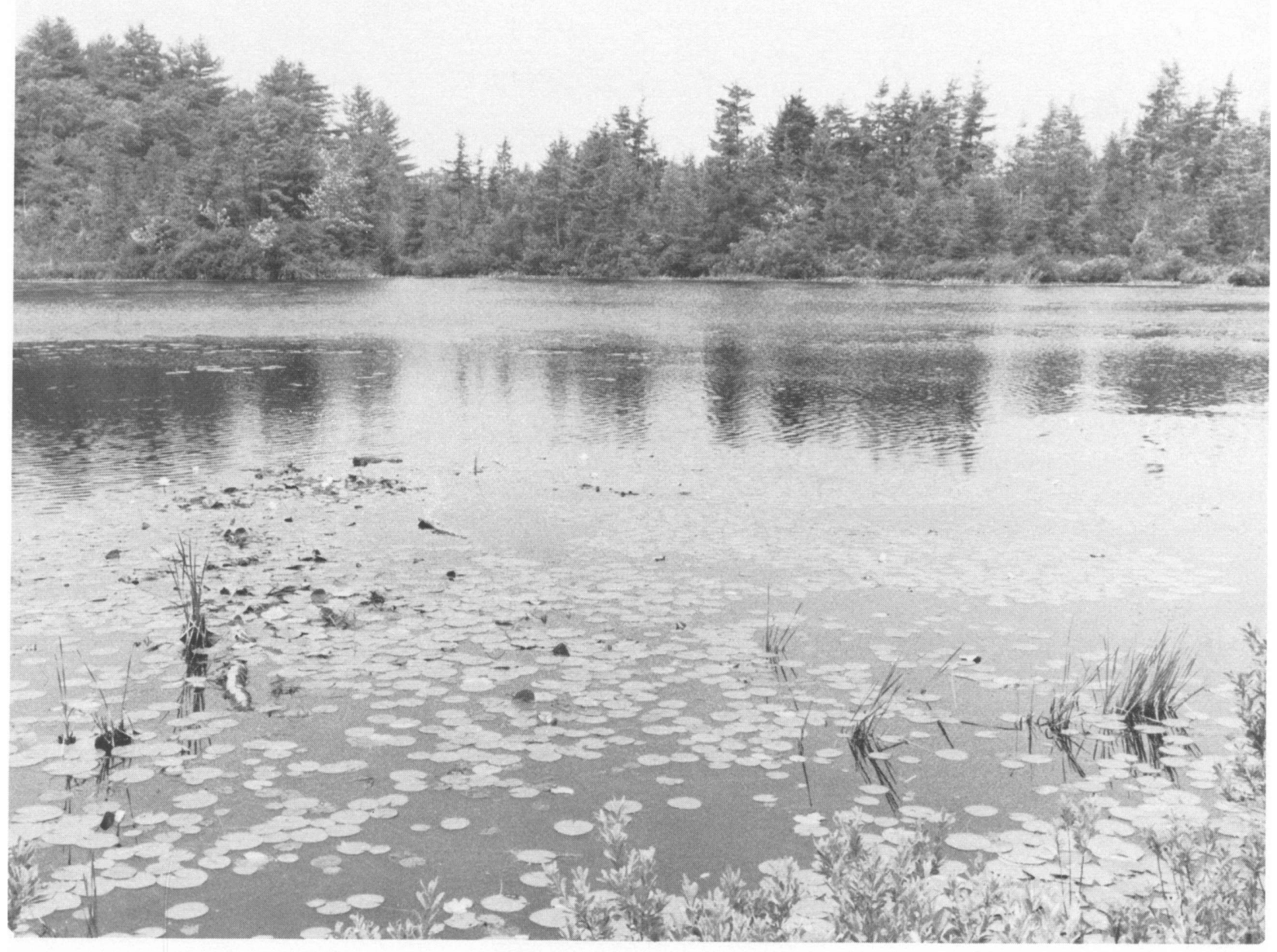

Plate 41.-Classification: SYSTEm Lacustrine, SUBSYSTem Limnetic, CLASS Aquatic Bed, subClass Rooted Vascular, DominanCE TYPE Nymphaea odorata, WATER REgIMe Permanently Flooded, wATER CHEMISTRY Fresh-Circumneutral. Subordinate plants in the Aquatic Bed include bladderworts (Utricularia spp.). Yellow-eyed grass (Xyris smalliana) grows on floating mats of peat along the shore (foreground). Water depth in this 0.8-ha (2-acre) bog lake exceeds $3 \mathrm{~m}$ (10 ft). (Washington County, Rhode Island; July 1977; Photo by F. C. Golet) 


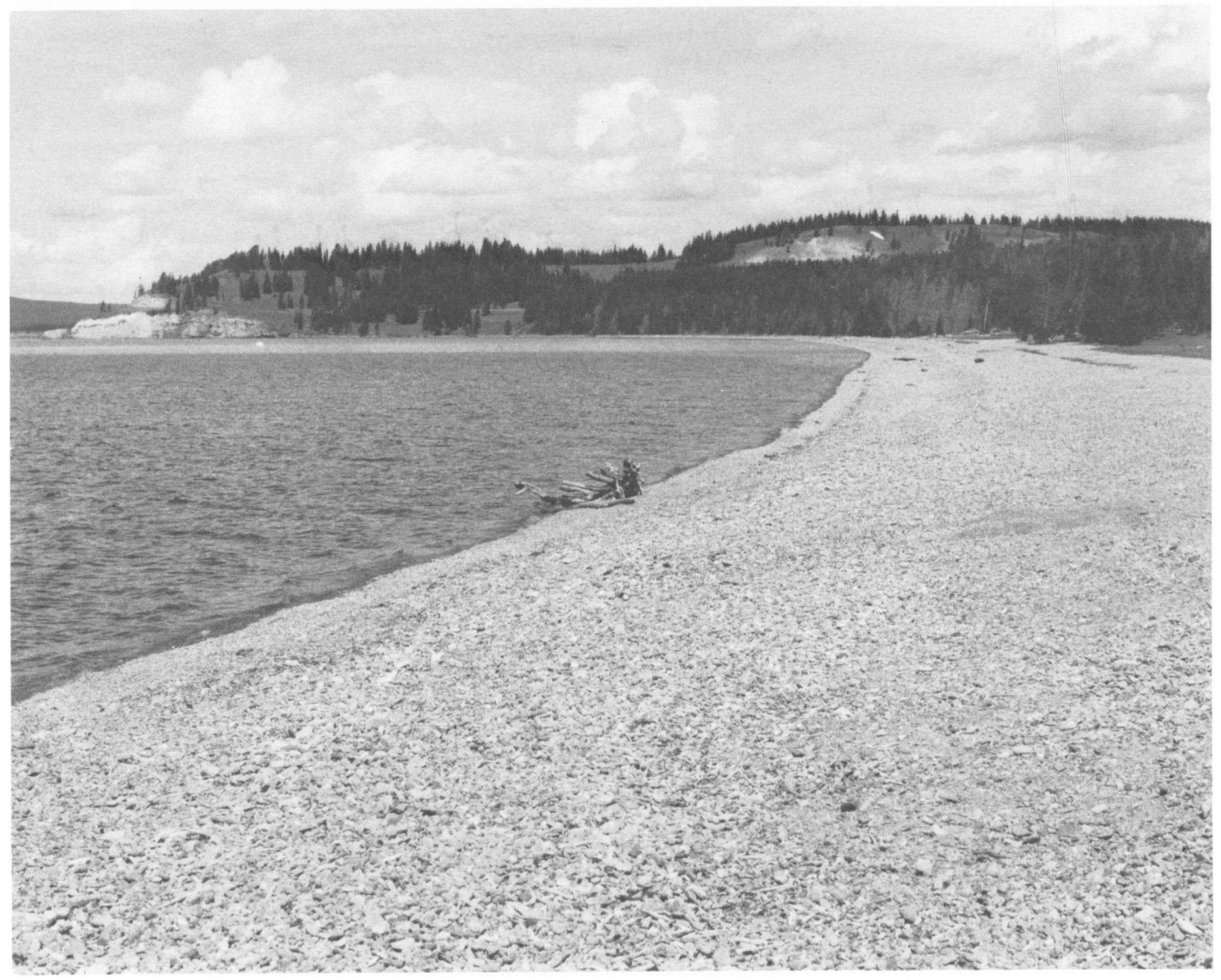

Plate 42.-Classification: SYSTEM Lacustrine, sUBSYSTEM Littoral, CLASs Unconsolidated Shore, sUBCLASS Cobble-Gravel, WATER REGIME Seasonally Flooded, WATER CHEMISTRY Fresh. At the time of photography, the level of Yellowstone Lake was near its seasonal low point. Due to snowmelt, the level of the lake rises to a peak in early July and then slowly declines until the following spring. This entire beach is inundated each summer. (Yellowstone National Park, Teton County, Wyoming; May 1985; Photo by F. C. Golet) 


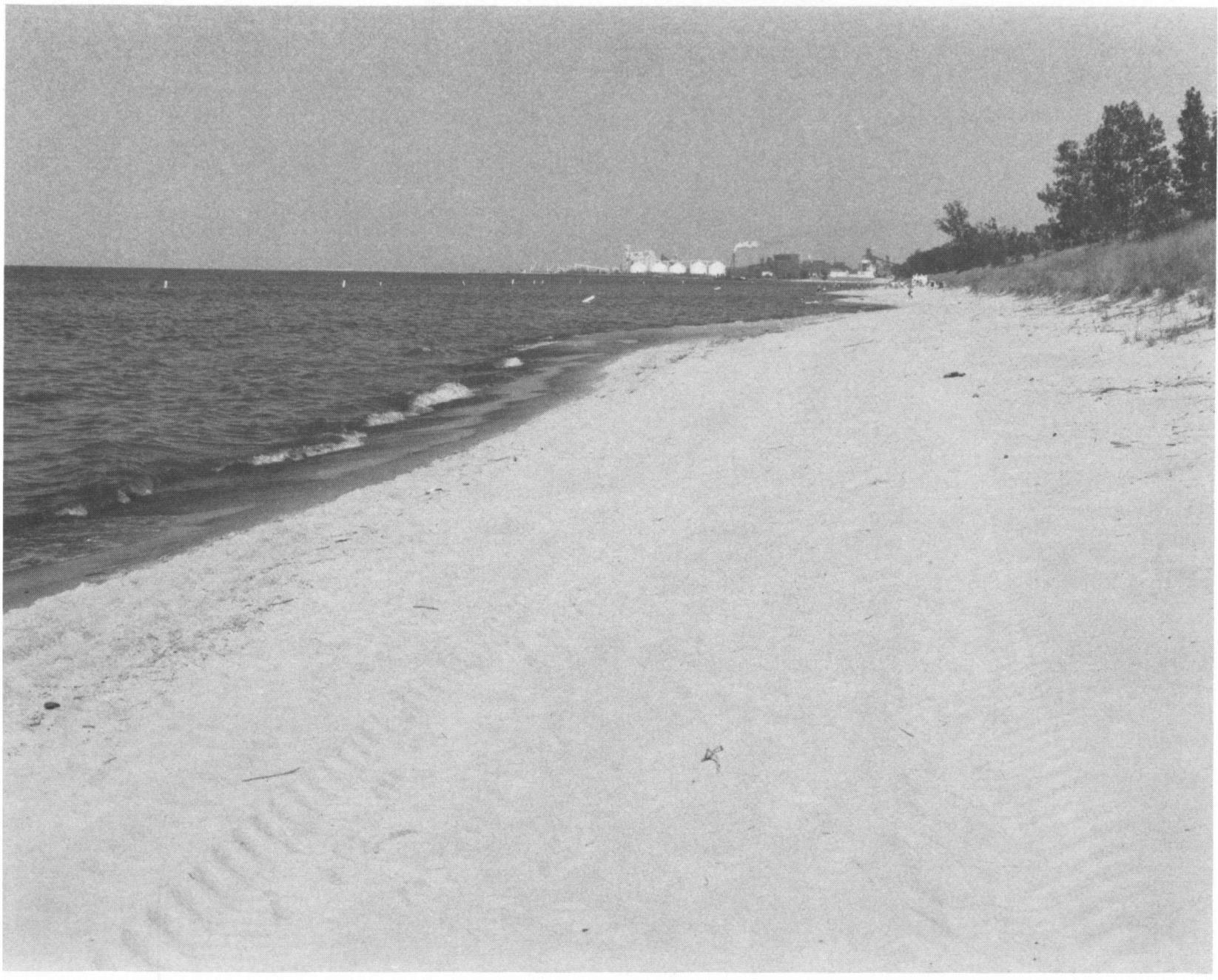

Plate 43.-Classification: SYSTEM Lacustrine, SUBSYSTEM Littoral, CLASS Unconsolidated Shore, SUBCLASS Sand, WATER REGIME Intermittently Flooded, WATER CHEMISTRY Fresh. Water levels in the Great Lakes generally fluctuate little during a single year, but they may rise and fall considerably over a period of several years. The water level in Lake Michigan was at an all-time high when this photo was taken. As a result of long-term changes in lake levels and seiches produced by storms, lake waters inundate part or all of this beach on an irregular basis. (Indiana Dunes National Lakeshore, Porter County, Indiana; May 1985; Photo by F. C. Golet) 


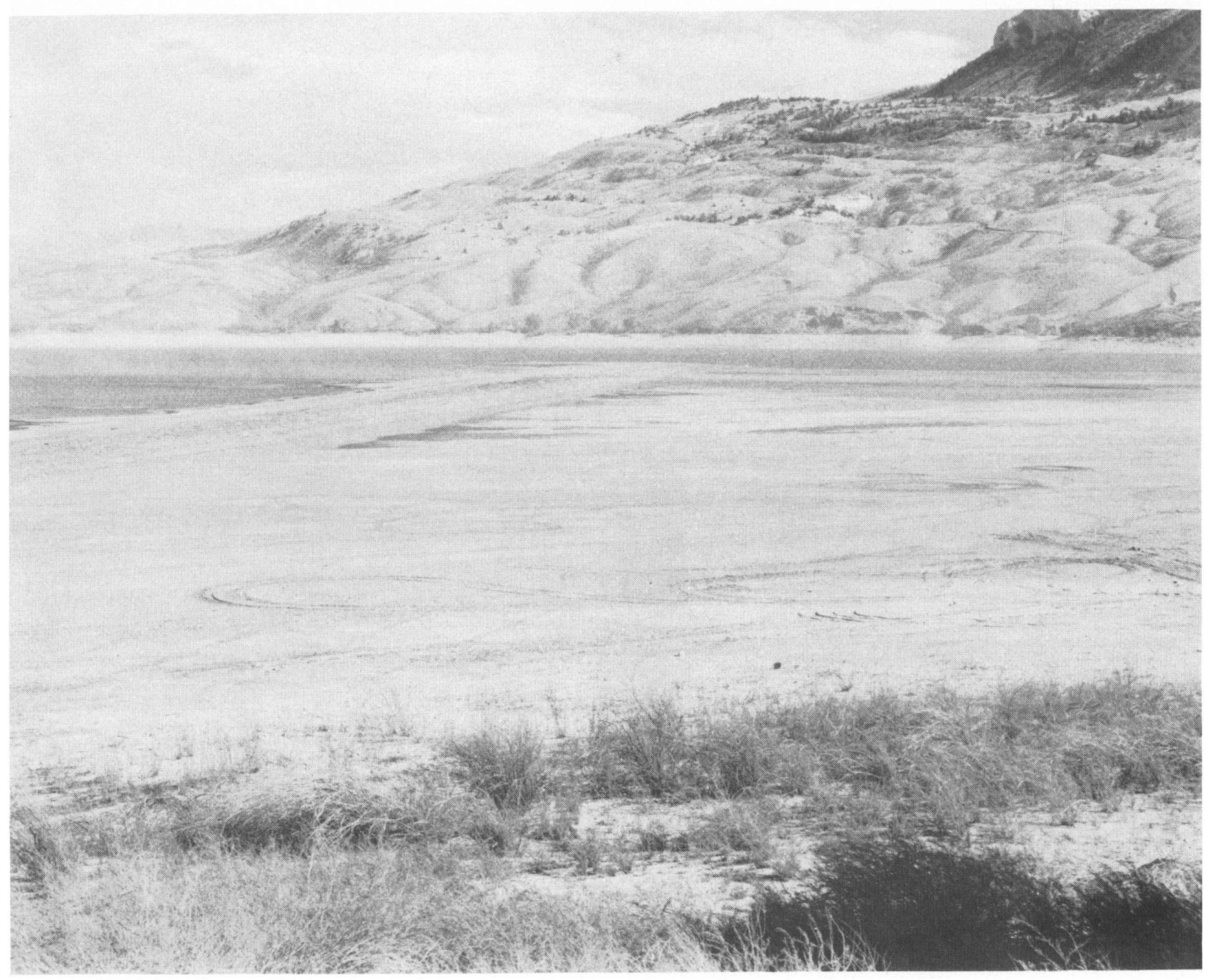

Plate 44.-Classification: SYSTEM Lacustrine, SUBSYSTEM Littoral, ClASS Unconsolidated Shore, sUBCLASS Mud, WATER REGIMES Temporarily Flooded and Seasonally Flooded, WATER CHEMISTRY Fresh, soIL Mineral, SPECIAL MODIFIER Impounded. The flats exposed along the shore of this reservoir are temporarily flooded; the seasonally flooded zone is still inundated at the time of this spring photograph. (Park County, Wyoming; May 1985; Photo by F. C. Golet) 


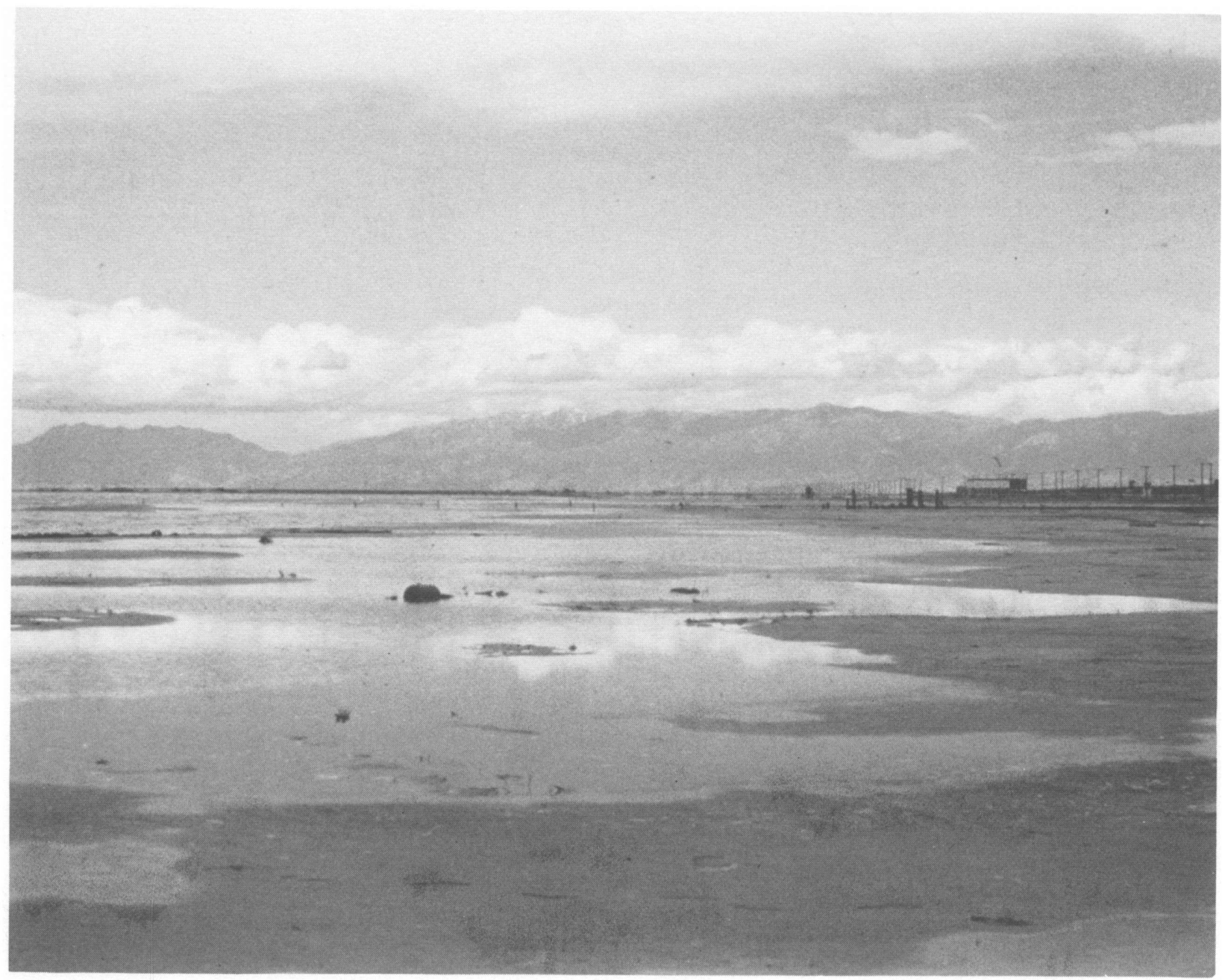

Plate 45.-Classification: SYSTEM Lacustrine, SUBSYSTEM Littoral, CLASS Unconsolidated Shore, sUBCLASS Mud, waTER REgIME Seasonally Flooded, water CHEMISTRY Hypersaline. (Salt Lake County, Utah; June 1973; Photo by V. Carter) 


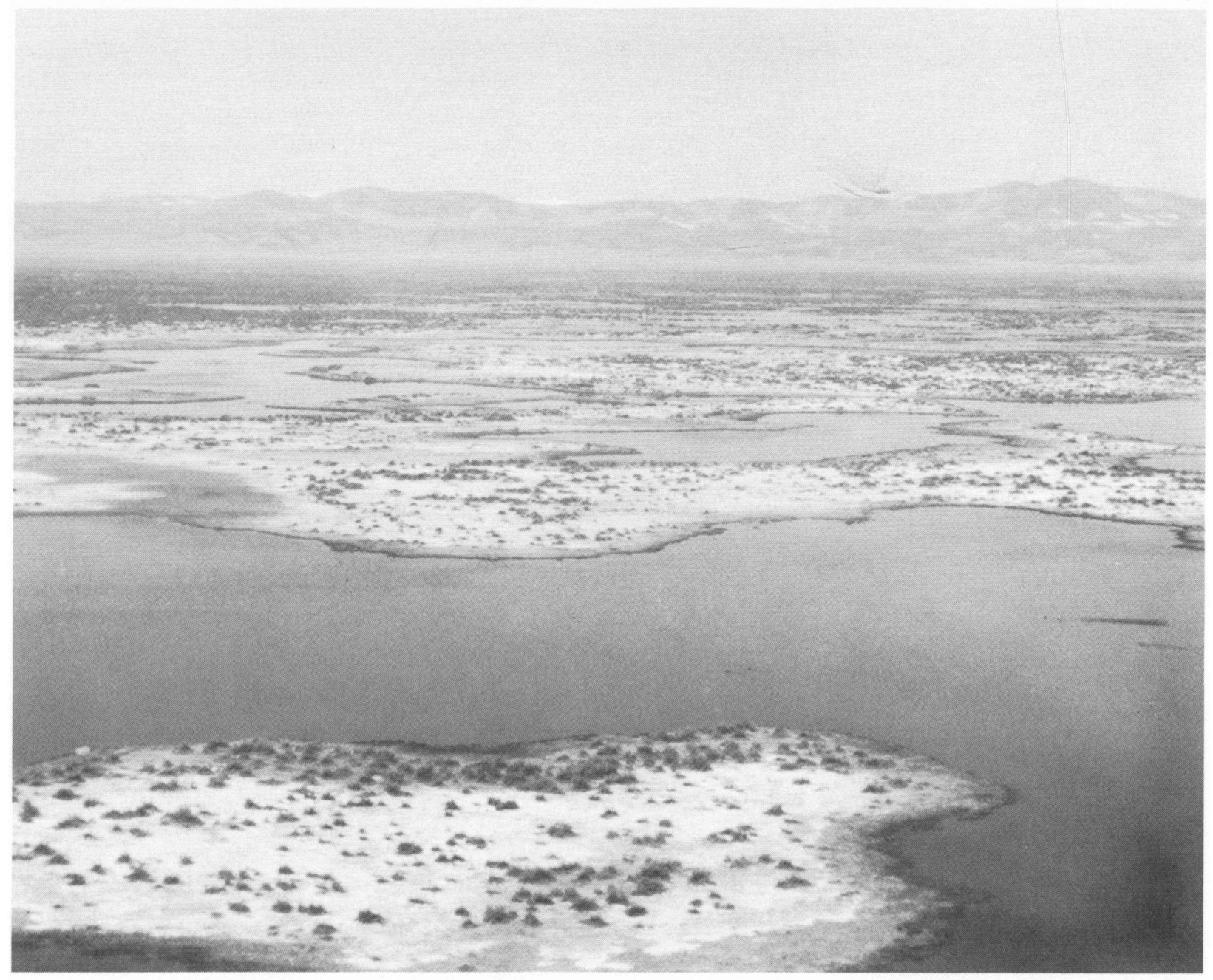

Plate 46.-Two habitats are shown here. Classification of exposed areas: SYSTEM Lacustrine, sUBSYSTEM Littoral, CLASS Unconsolidated Shore, SUBCLASS Mud, WATER REGIMES Intermittently Flooded (light-colored soil) and Seasonally Flooded (darker soil along water's edge), WATER CHEMISTRY Mixosaline, sorl Mineral. Classification of inundated areas: SYSTEM Lacustrine, sUBSYSTEM Littoral, CLASS Unconsolidated Bottom, SUBCLASS Mud, WATER REGIME Semipermanently Flooded, waTER CHEMISTRY Mixosaline, soll Mineral. Greasewood (Sarcobatus vermiculatus), salt grass (Distichlis spicata), and rushes (Juncus spp.) are scattered across the flats. Because annual precipitation averages only about $18 \mathrm{~cm}(7 \mathrm{in})$ here, these wetlands are heavily dependent upon snowpack in the surrounding mountains as a source of water. (Saguache County, Colorado; Photo by R. M. Hopper) 


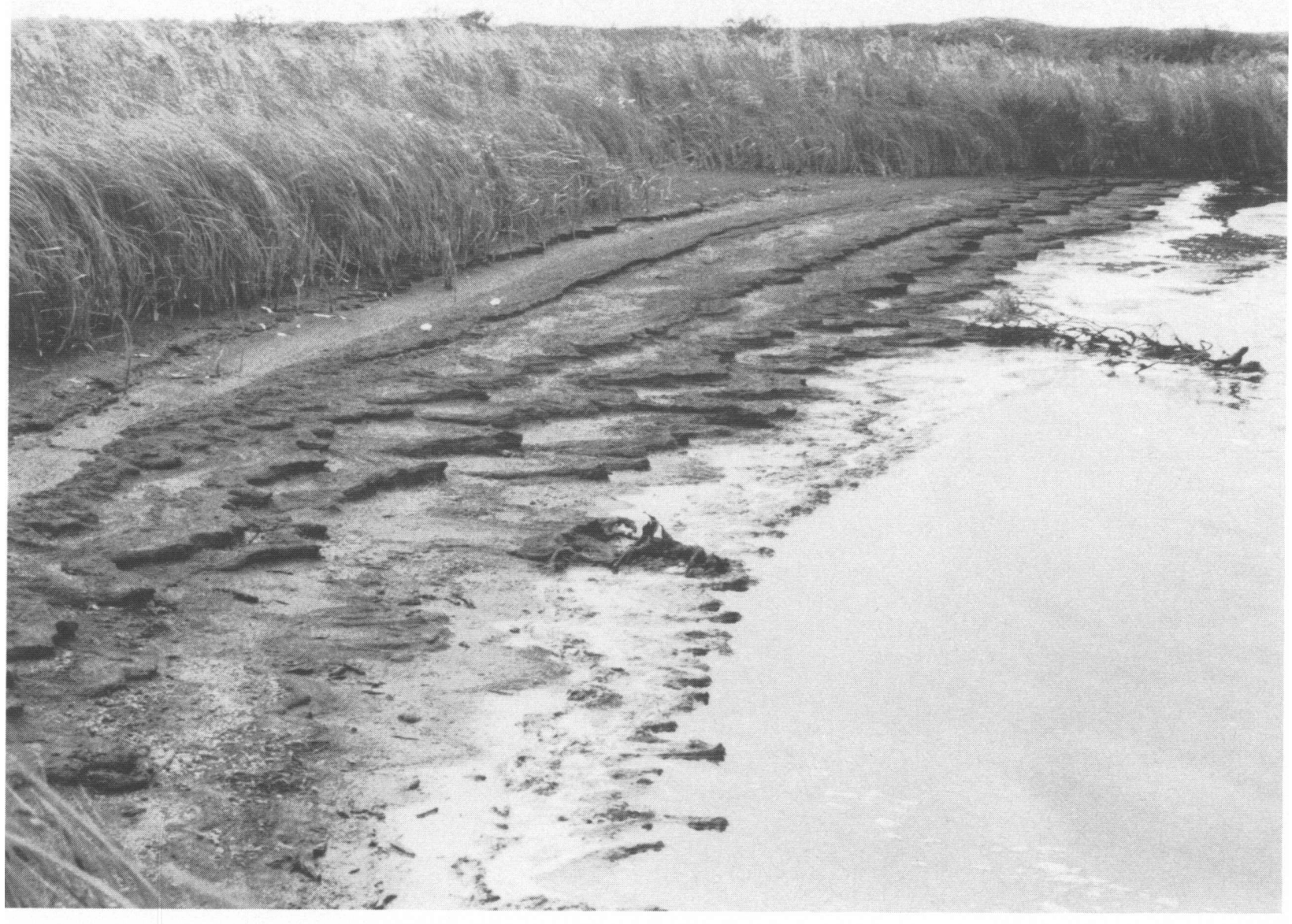

Plate 47.-Classification: SYSTEM Lacustrine, SUBSYSTEM Littoral, CLASS Unconsolidated Shore, SUBCLASS Organic, WATER REGIME Seasonally Flooded, WATER CHEMISTRY Fresh. This beach is only $15 \mathrm{~m}(50 \mathrm{ft})$ long and $2 \mathrm{~m}(6-7 \mathrm{ft})$ wide. Such organic shores are common in certain areas of the Yukon-Kuskokwim Delta, and many are considerably larger than the one shown here. Evidence of the decline in lake levels over the summer can be seen in the series of low ridges in the peat. Surrounding vegetation includes sedge (Carex lyngbyei), bluejoint (Calamagrostis canadensis), and willows (Salix spp.). (Talik River area, Yukon-Kuskokwim Delta, Alaska; July 1985; Photo by F. C. Golet) 


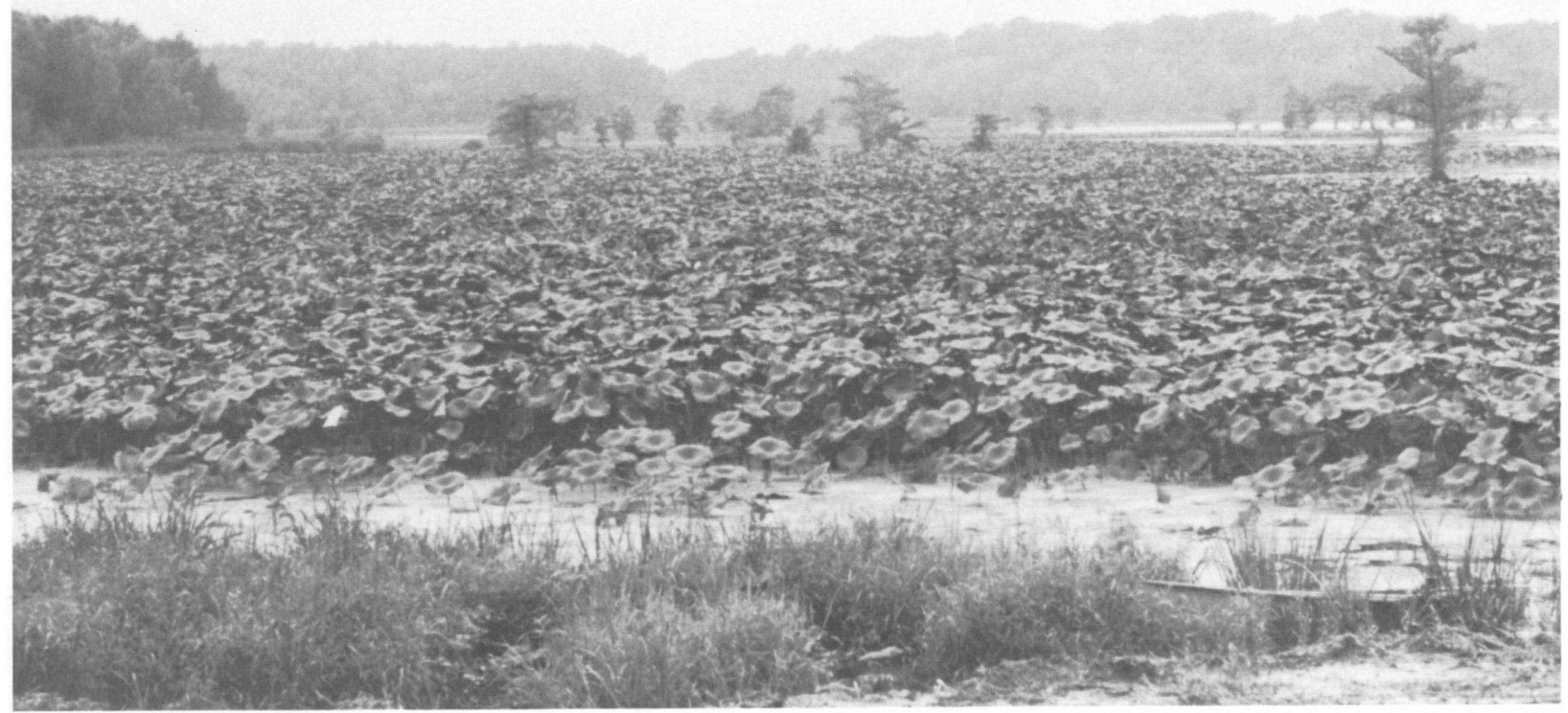

Plate 48.-Classification: SYSTEM Lacustrine, SUBSYSTEM Littoral, CLASS Emergent Wetland, SUBCLASS Nonpersistent, DOMINANCE TYPe Nelumbo lutea, wATer REgIme Permanently Flooded, water chemistry Fresh-Circumneutral, soil Mineral, SPECIAL MODIFIER Impounded. Subordinate plants are duckweeds (Lemna spp.) and bald cypress (Taxodium distichum). (Obion County, Tennessee; September 1975; Photo by V. Carter) 


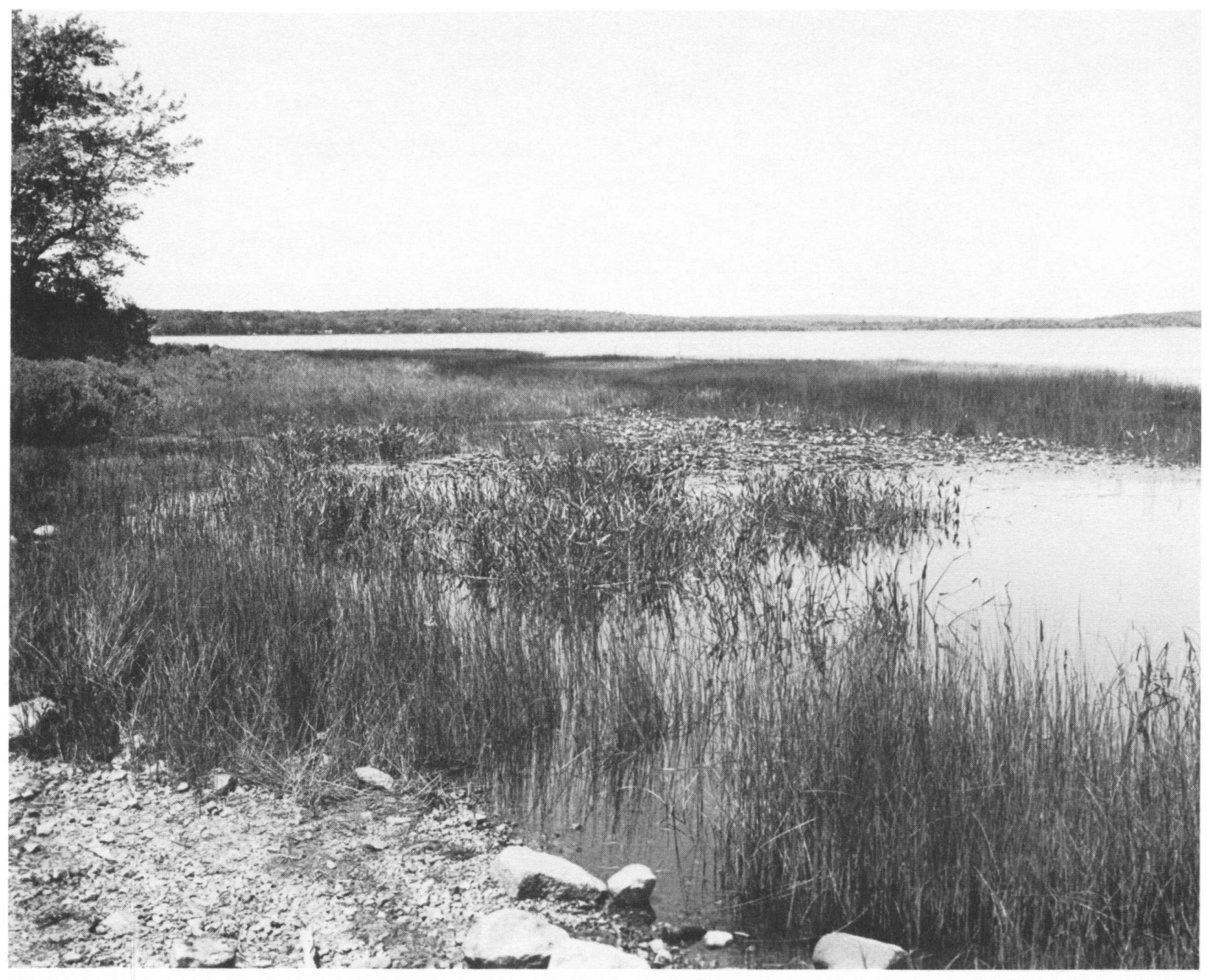

Plate 49.-Classification: SYSTEm Lacustrine, SUBSYSTEm Littoral, Class Emergent Wetland, SUbCLASs Nonpersistent, DominaNCE TYPE Juncus militaris, WATER REGIME Semipermanently Flooded, wATER CHEMISTRY Fresh-Circumneutral, soIL Mineral. Subordinate plants include common threesquare (Scirpus americanus) and pickerelweed (Pontederia cordata). During the spring, emergent vegetation is not evident at this site, and waves break on the gravel shore visible in the foreground. (Washington County, Rhode Island; July 1977; Photo by F. C. Golet) 


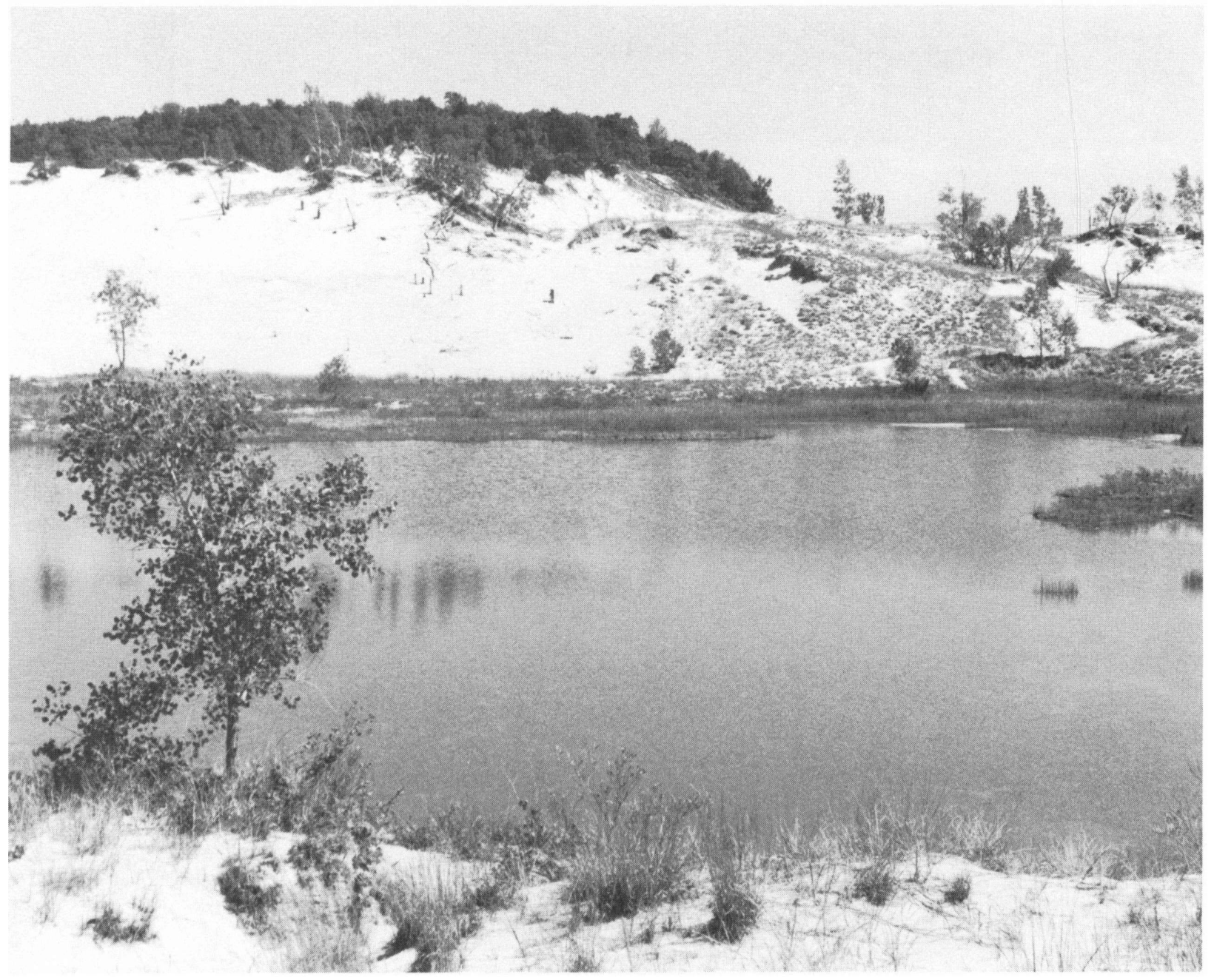

Plate 50.-Classification: system Palustrine, Class Unconsolidated Bottom, subClass Sand, water REgIME Intermittently Exposed, WATER CHEMISTRY Fresh-Alkaline. Rushes (Juncus spp.), spike rush (Eleocharis sp.), and smartweed (Polygonum sp.) grow in shallow water along the shore of this 0.4 -ha (1-acre) pond which occupies a depression amidst sand dunes on the southern shore of Lake Michigan. (Indiana Dunes National Lakeshore, Porter County, Indiana; May 1985; Photo by F. C. Golet) 


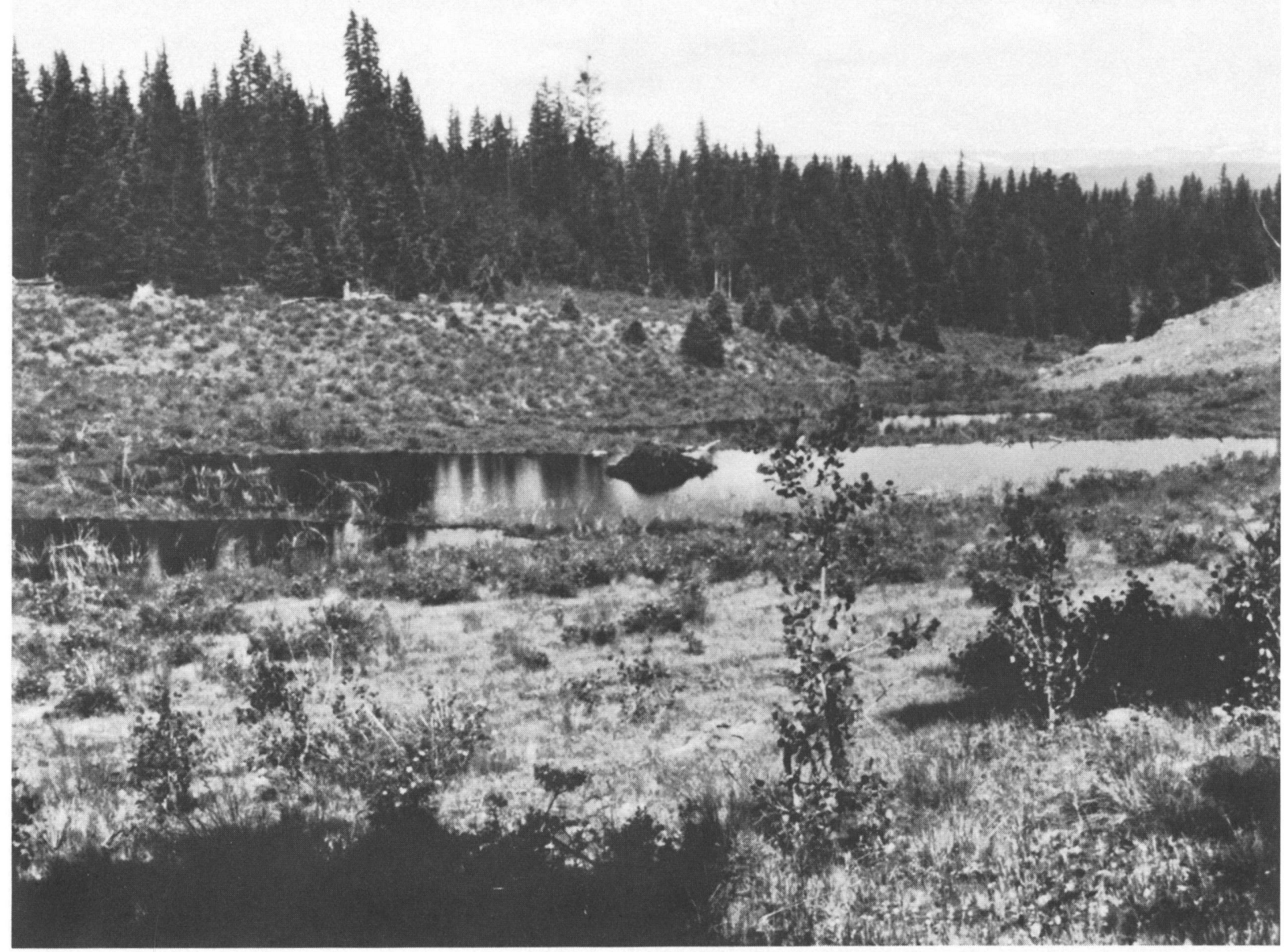

Plate 51.-Classification: SYSTEM Palustrine, CLASS Unconsolidated Bottom, SUBCLASS Mud, water REgime Permanently Flooded, WATER CHEMISTRY Fresh-Circumneutral, SPECIAL MODIFIER Impounded. This beaver pond is situated in the San Juan Mountains. (Gunnison County, Colorado; Photo by R. M. Hopper) 


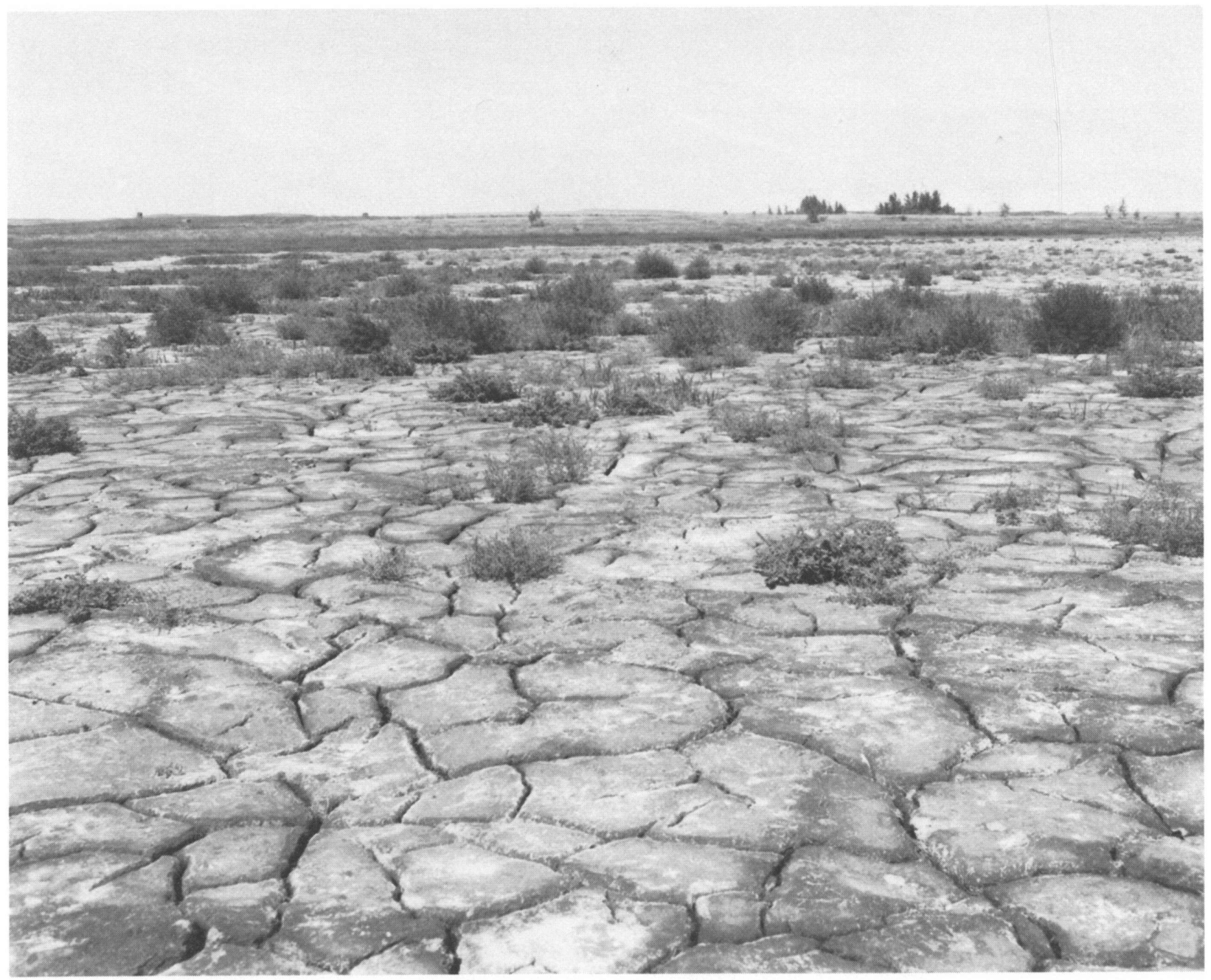

Plate 52.-Classification: system Palustrine, class Unconsolidated Bottom, sUbClass Mud, Water REgime Semipermanently Flooded, WATER CHEMISTRY Mesosaline, soll Mineral. This photo was taken during drouth conditions; the bottom is being invaded by pioneer species including summer cypress (Kochia scoparia), golden dock (Rumex maritimus), and goosefoot (Chenopodium glaucum). (Stutsman County, North Dakota; August 1961; Photo by R. E. Stewart) 


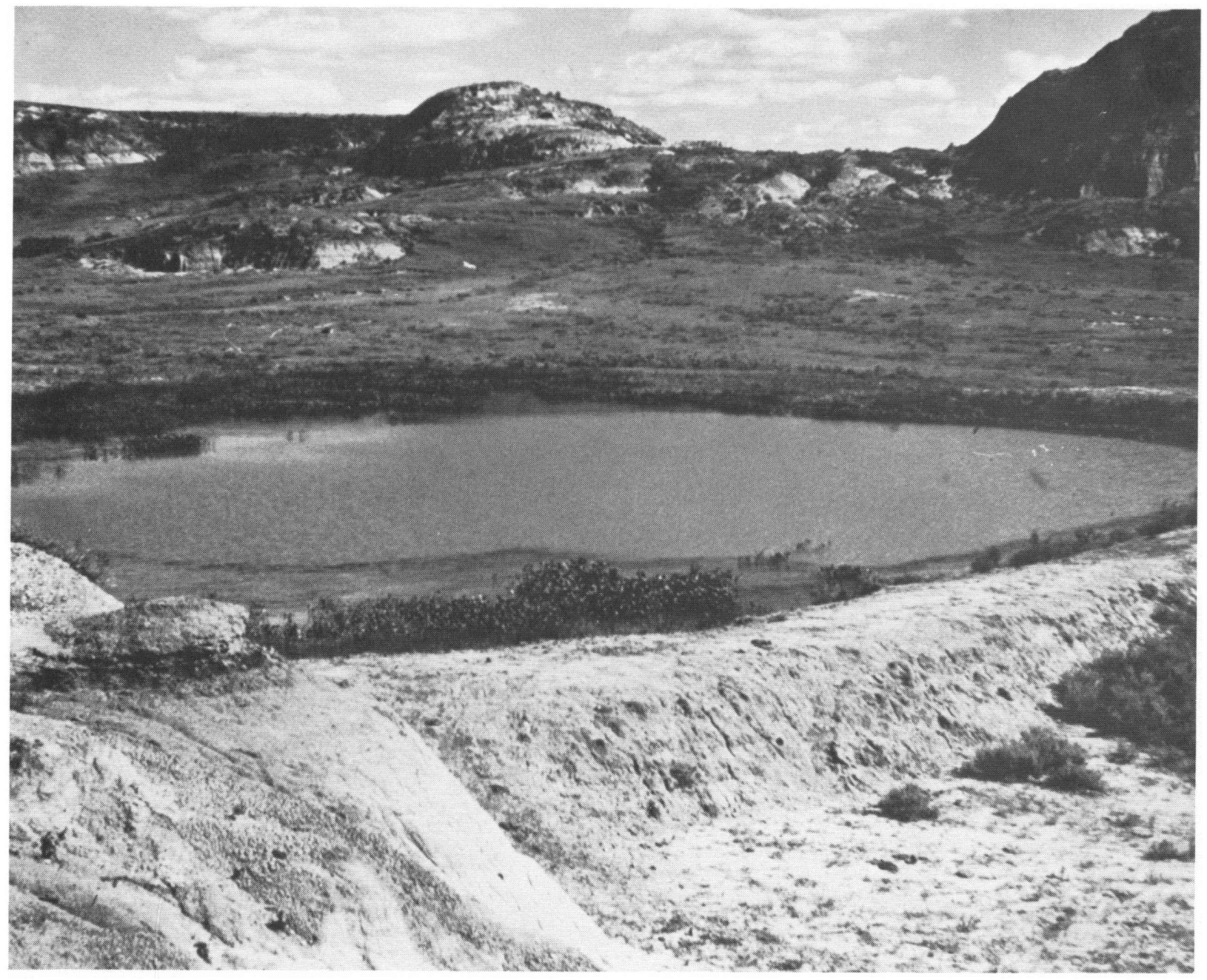

Plate 53.-Classification: SYSTEM Palustrine, Class Unconsolidated Bottom, subClass Mud, water REgime Semipermanently Flooded, WATER CHEMISTRY Fresh-Alkaline, soIL Mineral, sPECLAL MODIFIER Impounded. A sparse stand of water plantain (Alisma plantago-aquatica) appears along the edge of the impoundment. (Billings County, North Dakota; July 1970; Photo by J. T. Lokemoen) 


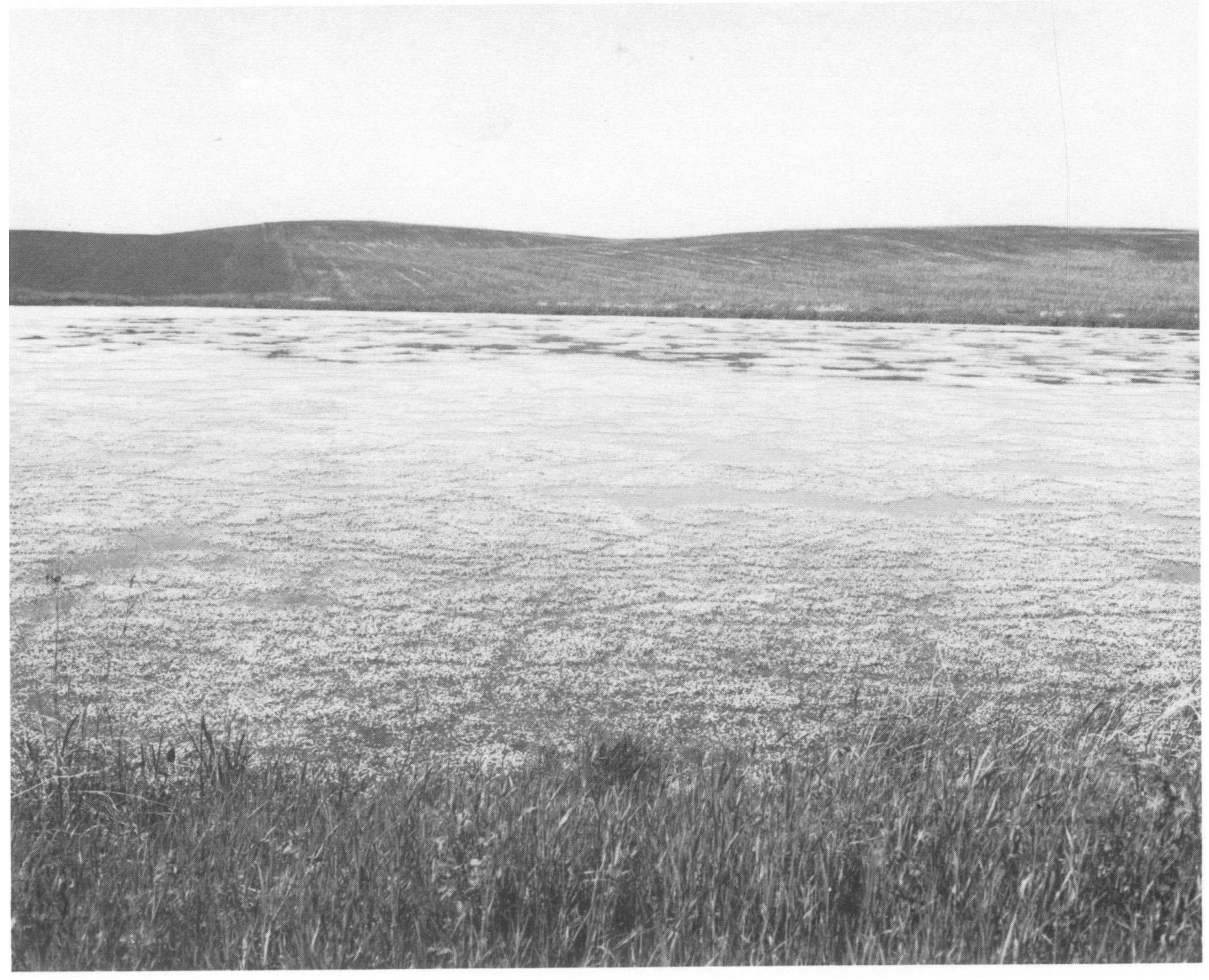

Plate 54.-Classification: SYSTEM Palustrine, Class Aquatic Bed, sUBCLASS Rooted Vascular, DominanCe TYPE Ranunculus trichophyllus, WATER REGIME Semipermanently Flooded, WATER CHEMISTRY Oligosaline, soIL Mineral. (Stutsman County, North Dakota; August 1966; Photo by R. E. Stewart) 


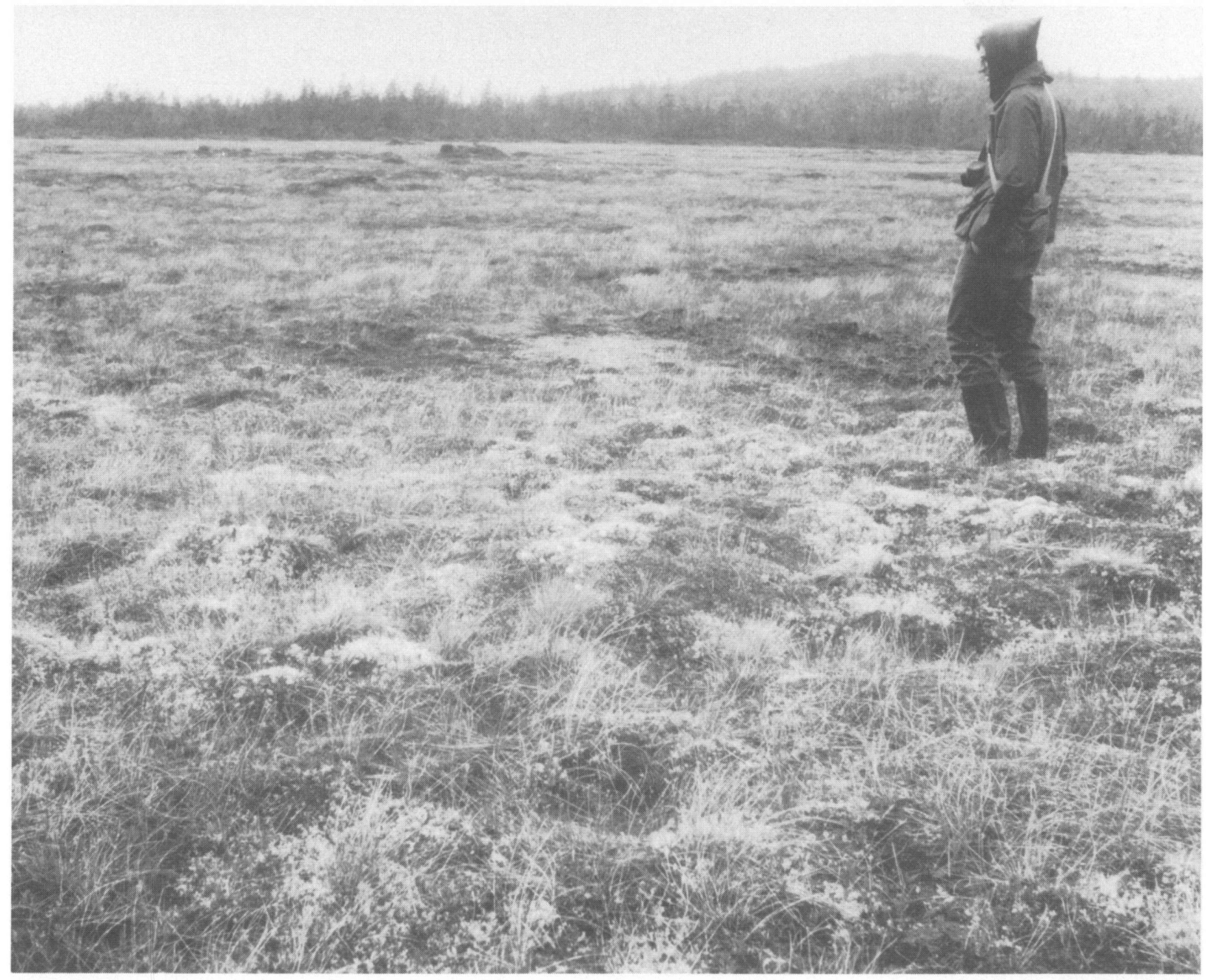

Plate 55.-Classification: system Palustrine, Class Moss-Lichen Wetland, subClass Moss, water Regime Saturated, water CHEMISTRY Fresh-Acid, soll Organic. The dominant plant is peat moss (Sphagnum spp.). Subordinate plants include reindeer moss (Cladina spp.), leatherleaf (Chamaedaphne calyculata), crowberry (Empetrum nigrum), and cottongrass (Eriophorum spp.). (Campobello Island International Park, Maine-Canada; June 1976; Photo by V. Carter) 


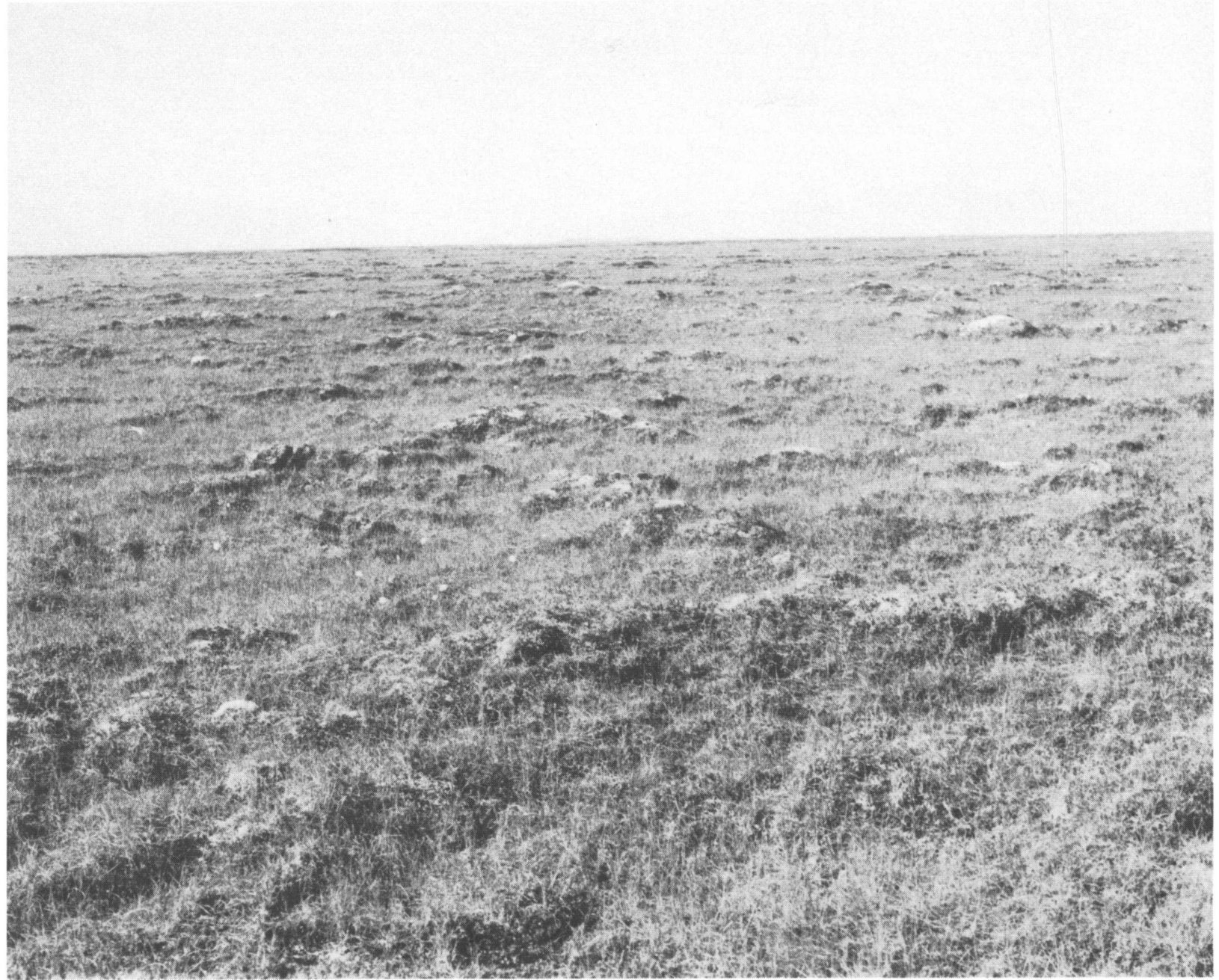

Plate 56.-Classification: system Palustrine, Class Moss-Lichen Wetland, subclass Moss, Water Regime Saturated, water CHEMISTRY Fresh. Peat moss (Sphagnum spp.) is the dominant plant. Subordinate plants include sedges (Carex rariflora, C. aquatilis), cottongrass (Eriophorum russeolum), and reindeer moss (Cladina spp.). While sedges are present, their combined cover is less than $30 \%$. Mosses cover $100 \%$ of the area. (Narokachik-Azun Rivers area, Yukon-Kuskokwim Delta, Alaska; July 1985; Photo by F. C. Golet) 


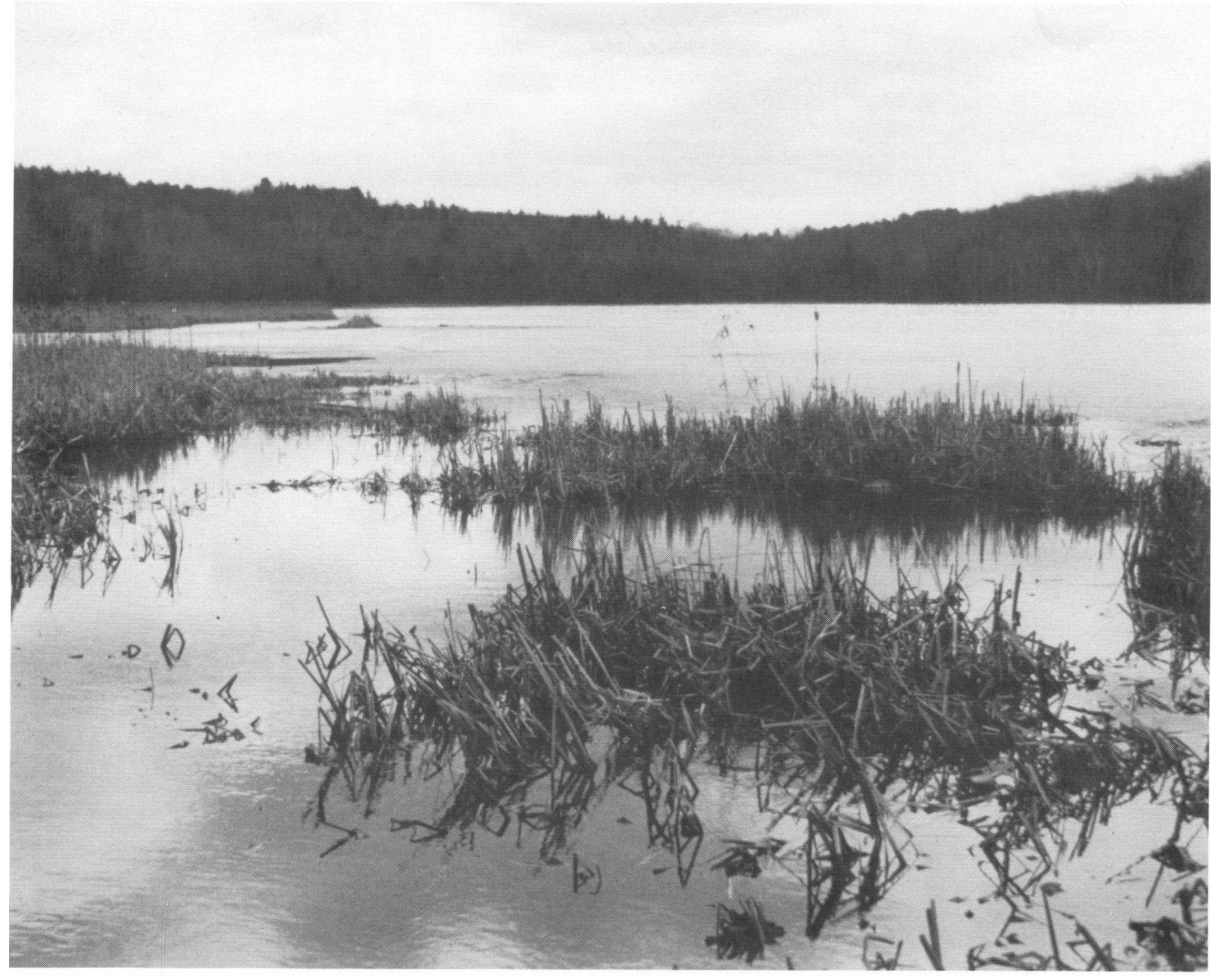

Plate 57.-Classification: SYSTEM Palustrine, Class Emergent Wetland, subClass Persistent, DominanCE TYPE Typha latifolia, WATER Regime Permanently Flooded, WATER CHEMISTRY Fresh, SPECIAL MODIFIER Impounded. Persistent emergents such as these cattails remain standing at least until the beginning of the next growing season. Note that the adjacent lake is ice-covered at the time of photography. (Knox County, Maine; April 1978; Photo by P. B. Reed) 


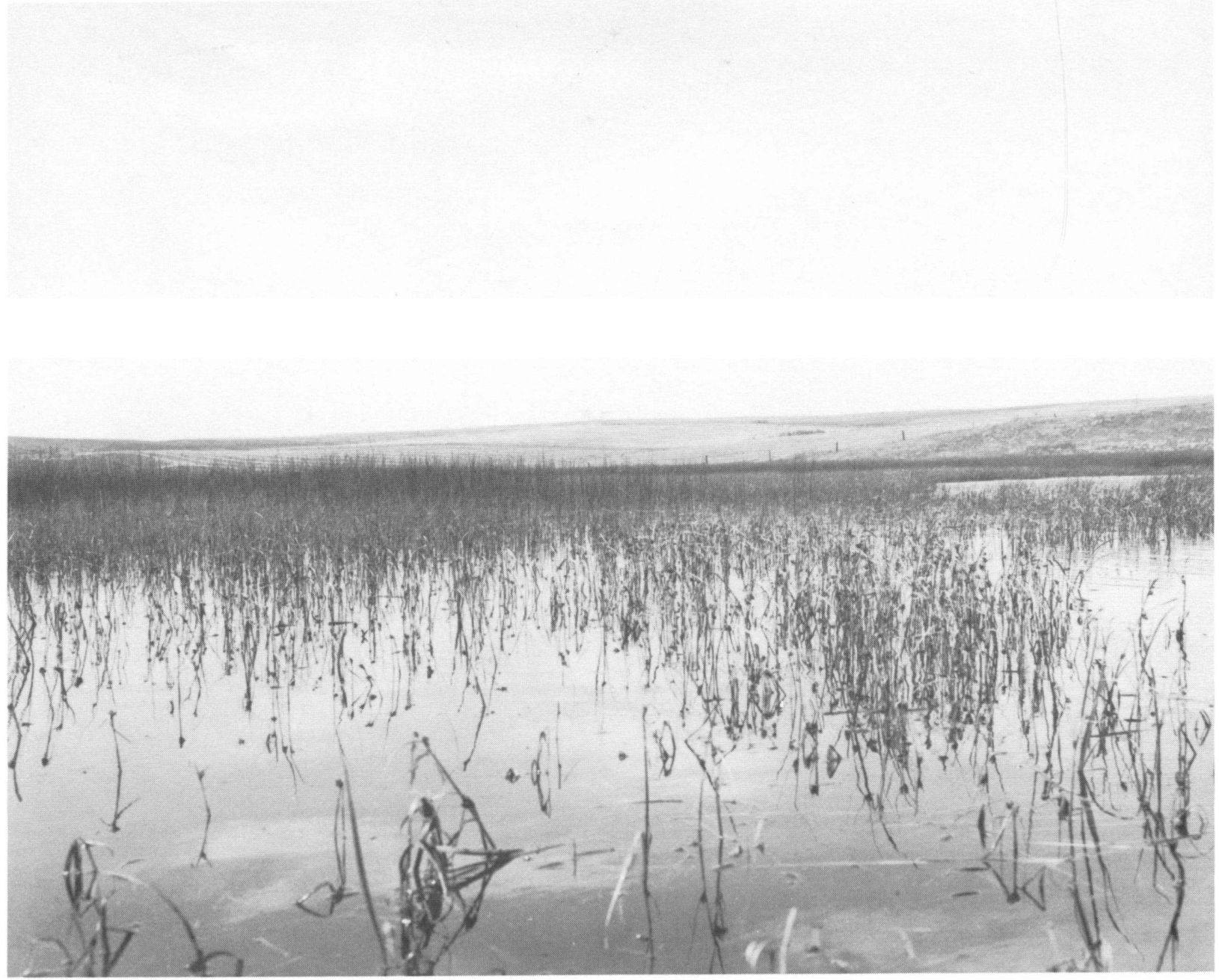

Plate 58.-Classification: SYSTEM Palustrine, CLASs Emergent Wetland, sUBCLASS Persistent, DOMINANCE TYPE Scirpus robustusScirpus acutus, WATER REgIME Semipermanently Flooded, WATER CHEMISTRY Mixosaline, soll Mineral. (Stutsman County, North Dakota; August 1962; Photo by R. E. Stewart) 


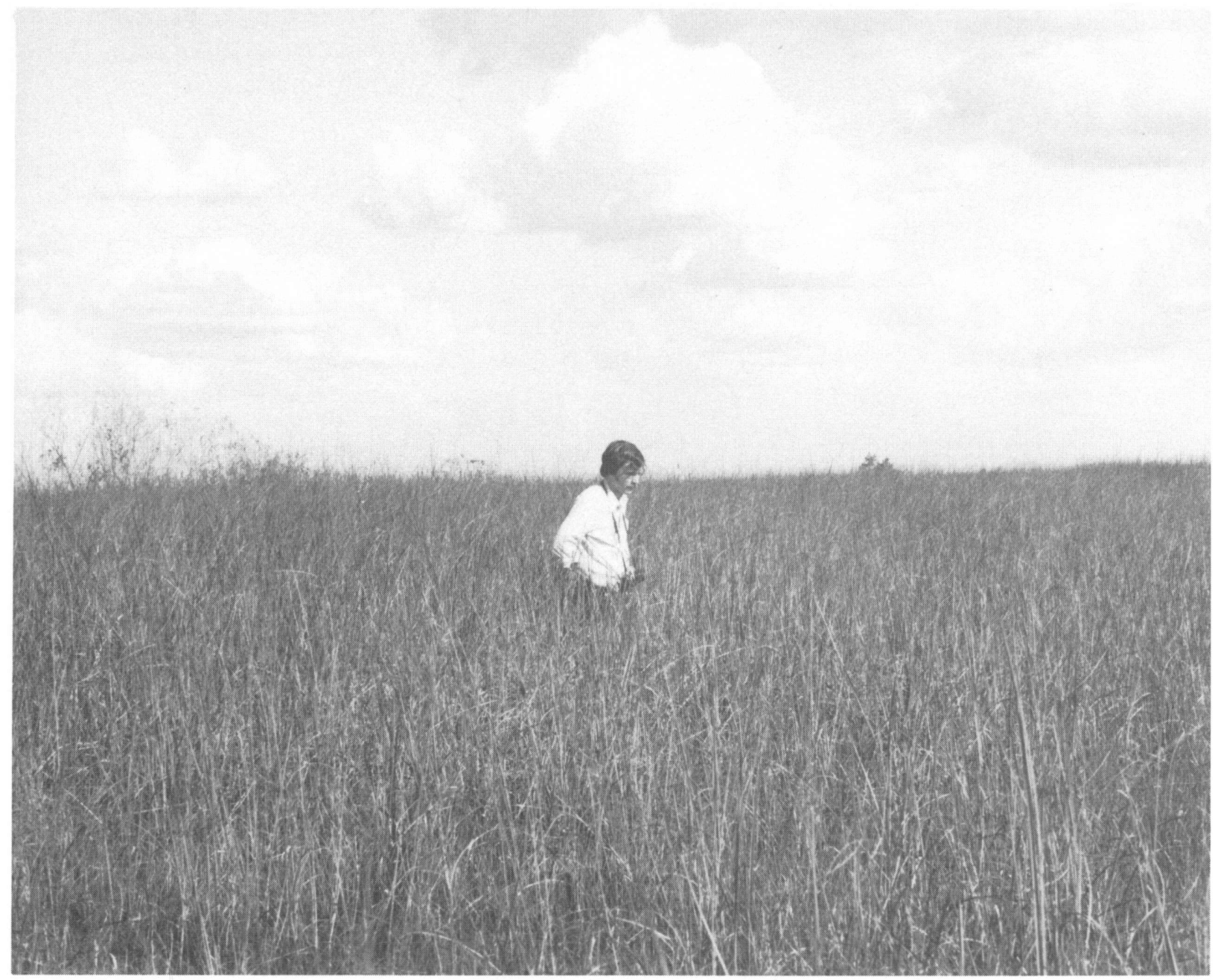

Plate 59.-Classification: SYSTEM Palustrine, ClASs Emergent Wetland, sUBCLASS Persistent, DOMINANCE TYPE Cladium jamaicense, WATER REGIME Semipermanently Flooded, wATER CHEMISTRY Fresh-Circumneutral, solL Organic. This photo was taken in the Florida Everglades. (Dade County, Florida; December 1975; Photo by V. Carter) 


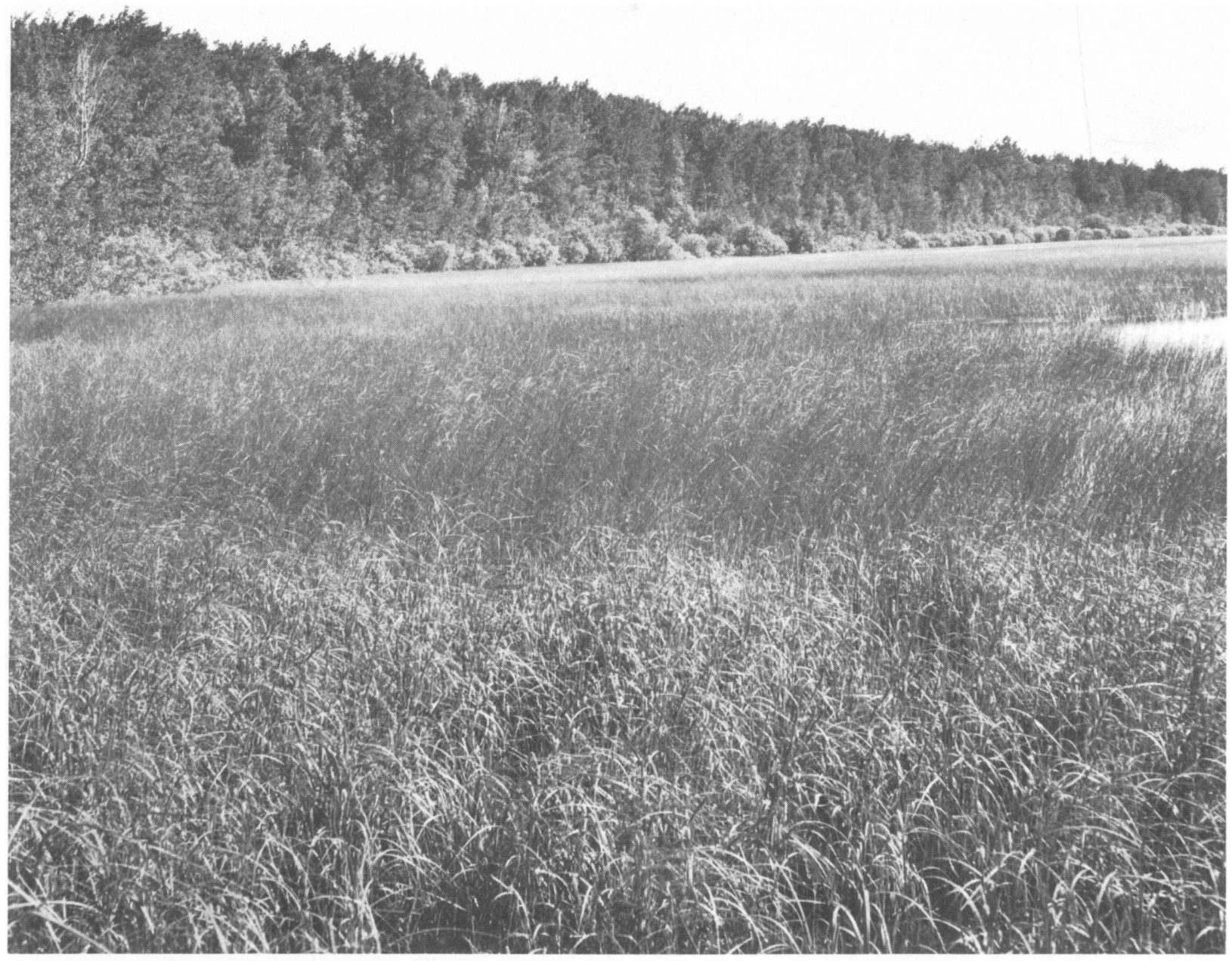

Plate 60.-Classification: SYSTEM Palustrine, CLASs Emergent Wetland, sUBCLASs Persistent, DominANCE TYPE Carex lasiocar$p a$, WATER REGIME Seasonally Flooded, wATER CHEMISTRY Fresh-Circumneutral, soIL Organic. Subordinate plants include sedges (Carex lacustris, C. rostrata), water smartweed (Polygonum amphibium), bladderwort (Utricularia macrorhiza), bluejoint (Calamagrostis canadensis), and pondweed (Potamogeton gramineus). (Chippewa National Forest, Beltrami County, Minnesota; June 1972; Photo by J. H. Richmann) 


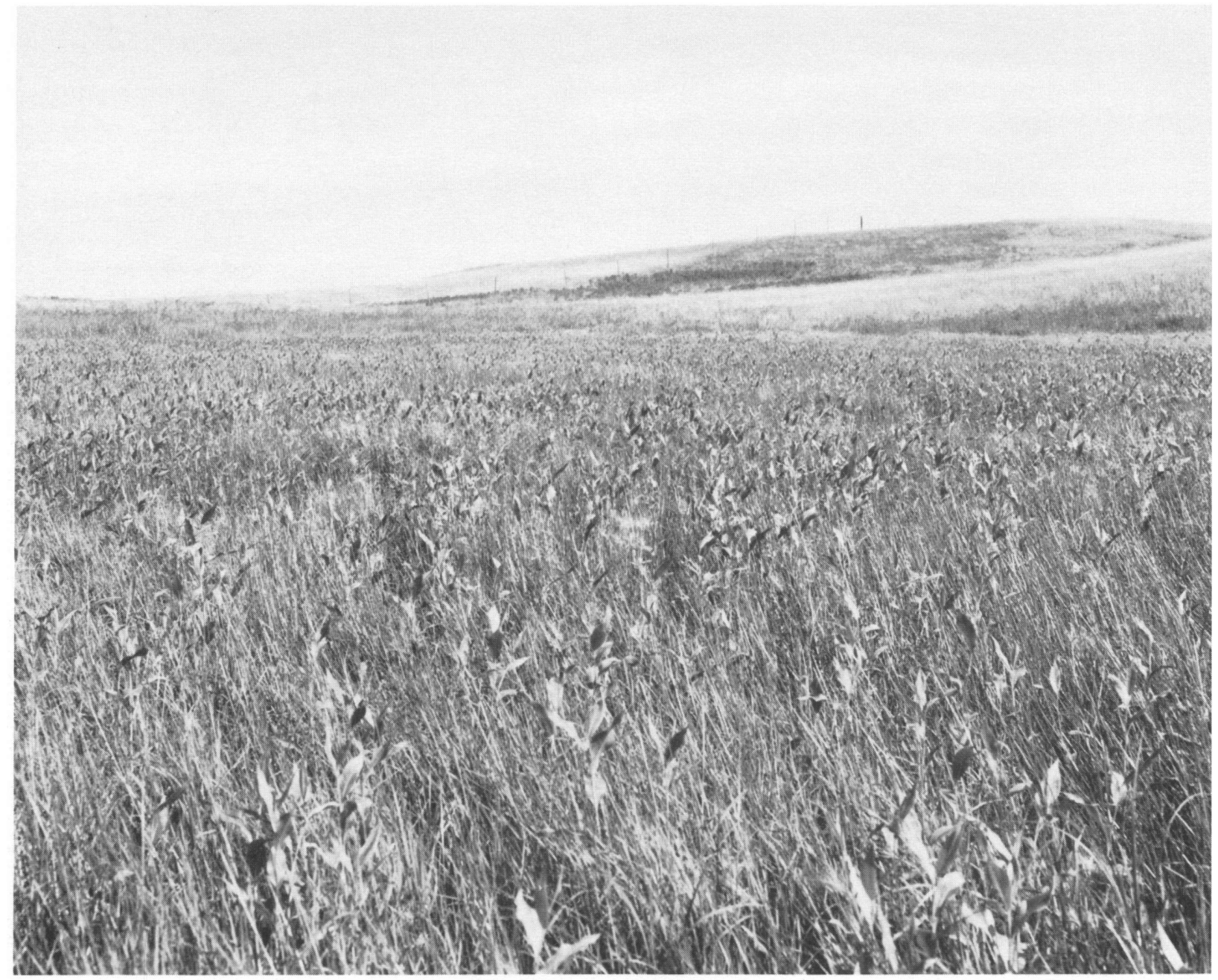

Plate 61.-Classification: SYSTEM Palustrine, CLASS Emergent Wetland, sUBCLASs Persistent, DOMINANCE TYPE Eleocharis palustris, WATER REgime Seasonally Flooded, Water Chemistry Polysaline, soll Mineral. Subordinate plants include water smartweed (Polygonum amphibium), slough sedge (Carex atherodes), and foxtail (Alopecurus aequalis). (Stutsman County, North Dakota; August 1962; Photo by R. E. Stewart) 


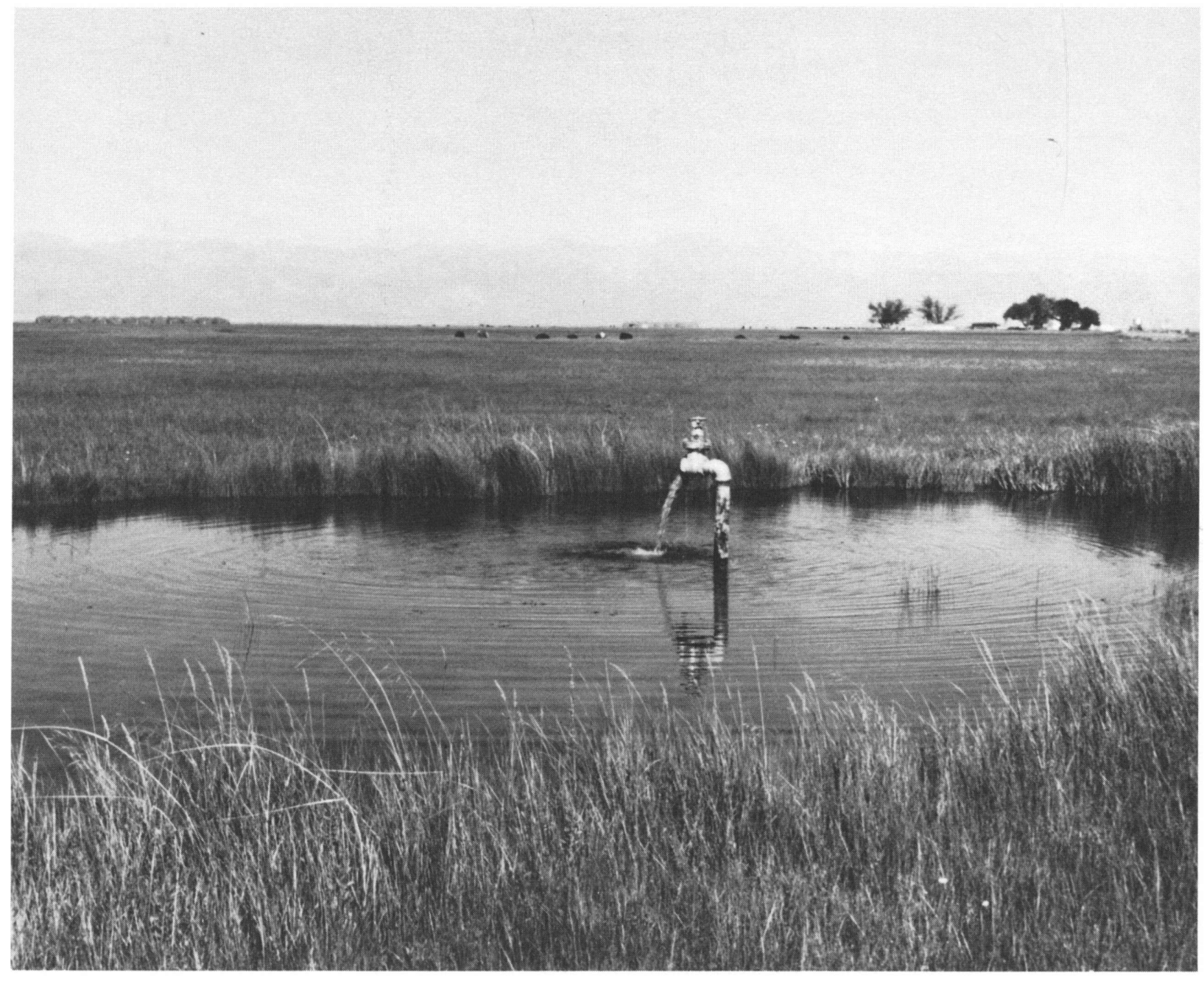

Plate 62.-Classification: SYstem Palustrine, Class Emergent Wetland, subClass Persistent, WATER REgime Seasonally Flooded, WATER CHEMISTRY Mixosaline, soIL Mineral. The principal plants are sedges (Carex spp.), bulrushes (Scirpus spp.), rushes (Juncus spp.), and foxtail (Alopecurus aequalis). This wetland is typical of irrigated hay in the West. Water may be diverted from rivers or may come from artesian wells as in this photo. (Saguache County, Colorado; Photo by R. M. Hopper) 


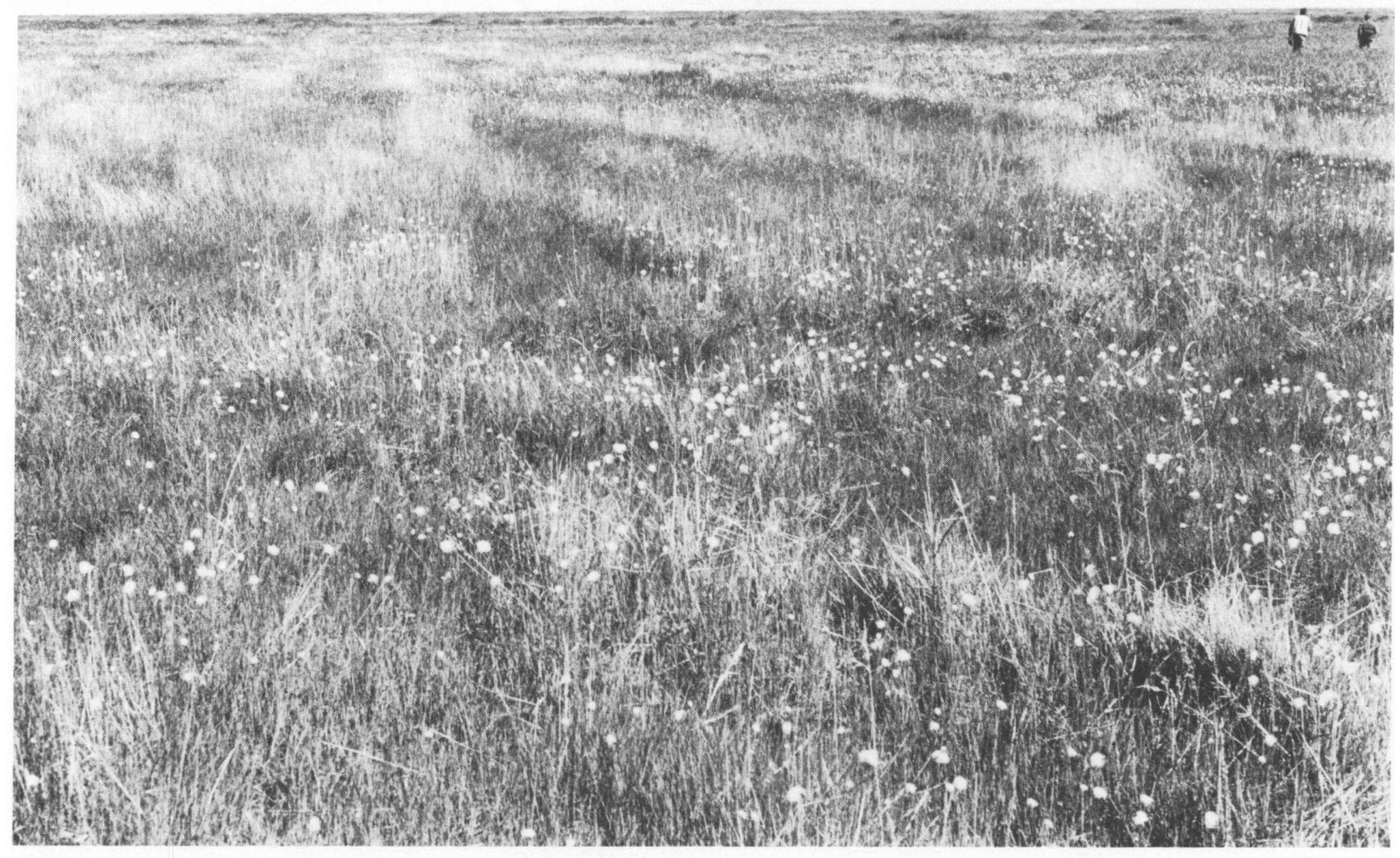

Plate 63.-Classification: SYSTEM Palustrine, CLASS Emergent Wetland, SUBCLASS Persistent, DominanCe TYPE Carex rarifloraEriophorum russeolum, WATER REGIME Seasonally Flooded, WATER CHEMISTRY Fresh. Subordinate plants include marsh cinquefoil (Potentilla palustris), bluejoint (Calamagrostis canadensis), Alaska bog willow (Salix fuscescens), crowberry (Empetrum nigrum), dwarf birch (Betula nana), and peat moss (Sphagnum sp.). This type of patterned wetland is commonly referred to as "string bog" or "strangmoor." Seasonally flooded troughs alternate with elongated bog-like ridges or "strings." Strings here rise only $30-45 \mathrm{~cm}$ (12-18 in) above the troughs. (Manokinak River area, Yukon-Kuskokwim Delta, Alaska; July 1985; Photo by F. C. Golet) 


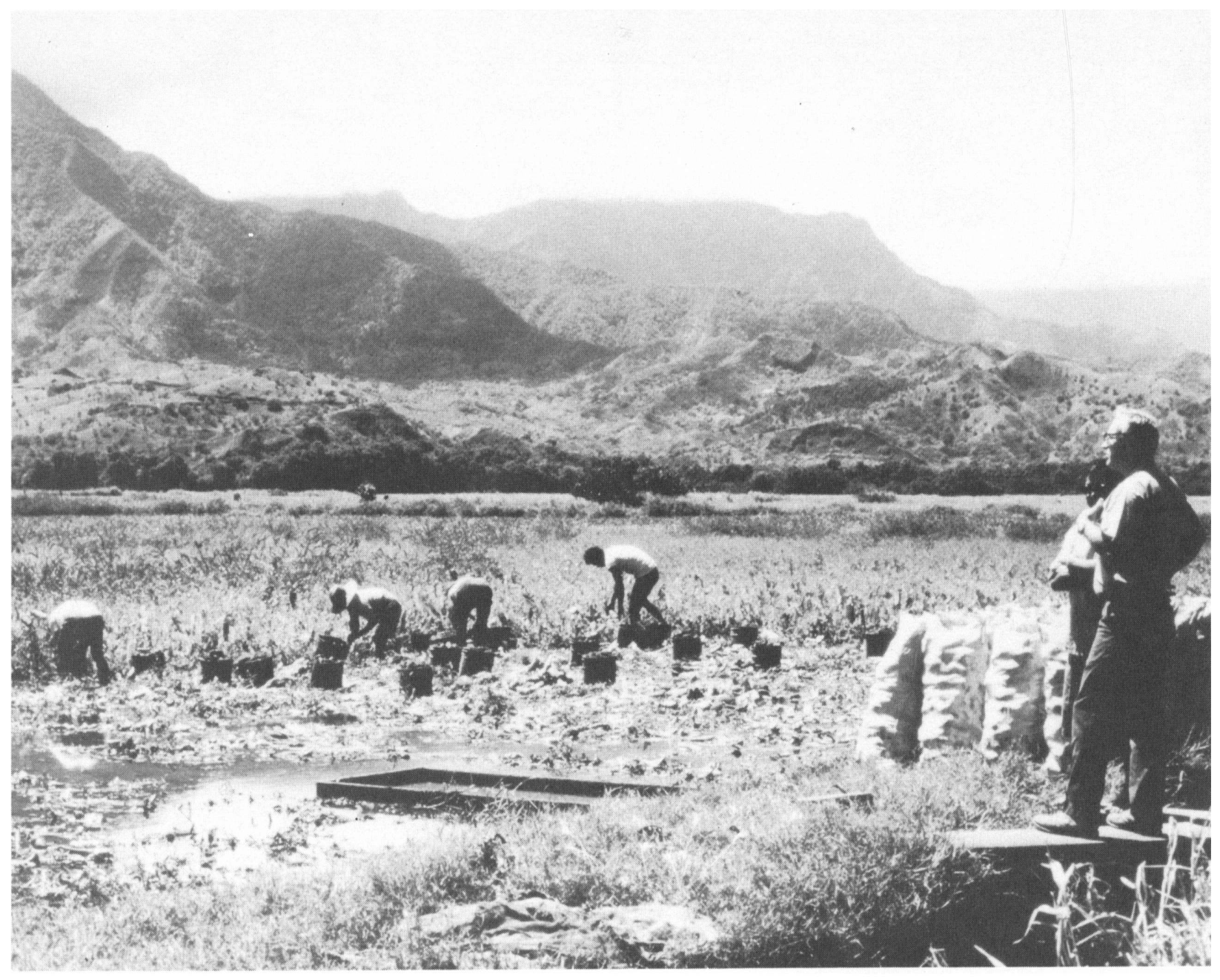

Plate 64.-Classification: SYSTEM Palustrine, CLASs Emergent Wetland, sUBCLAss Persistent, DOMINANCE TYPE Colocasia esculenta, WATER REgime Seasonally Flooded, WATER chemistry Fresh, soil Mineral, sPecial modifier Farmed. This photograph illustrates a Hawaiian taro field. (Kauai County, Hawaii; September 1972; Photo by E. Krider) 


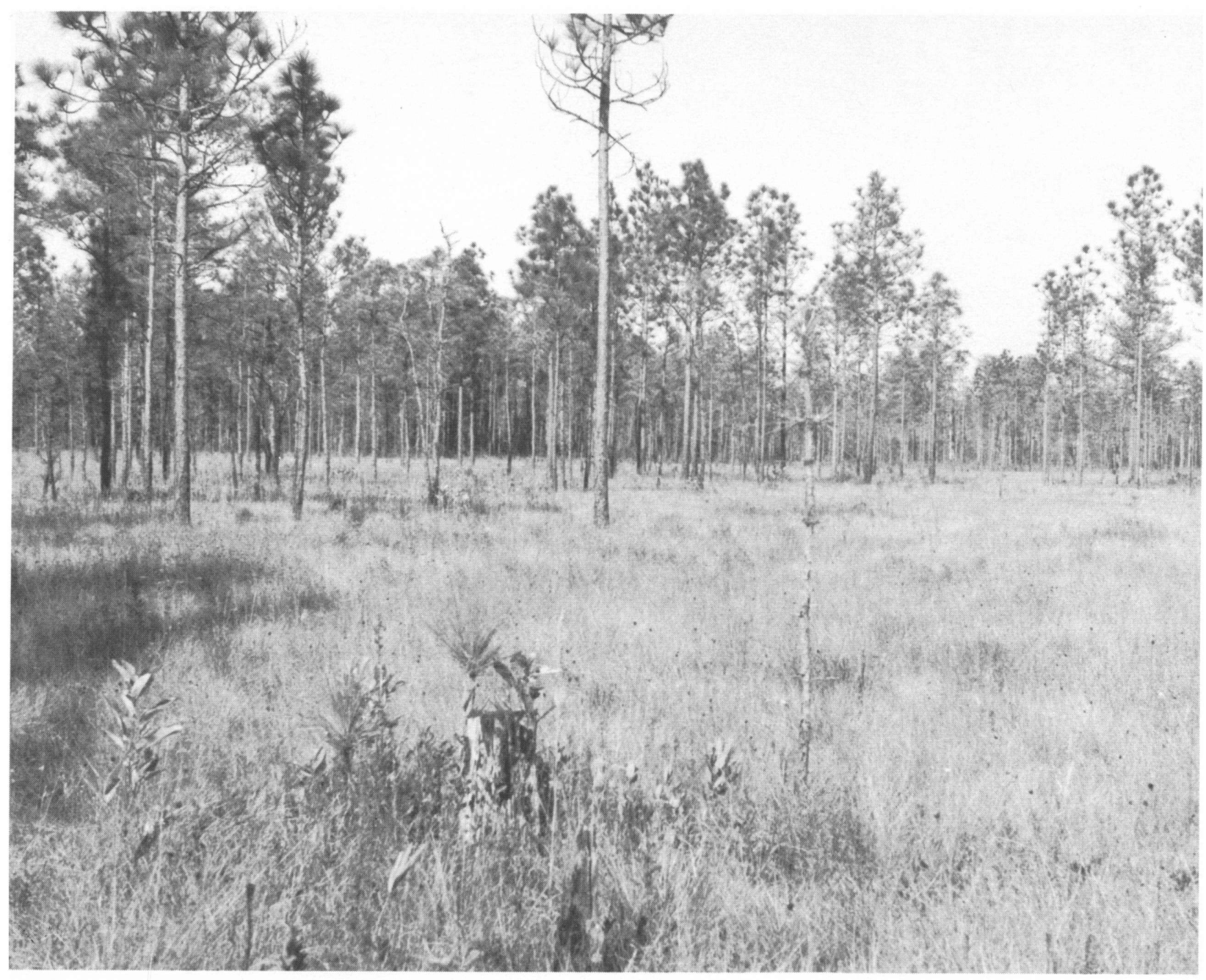

Plate 65.-Classification (foreground): SYSTEM Palustrine, CLASS Emergent Wetland, SUBCLASs Persistent, DOMINANCE TYPE Aristida stricta, WATER REGIME Saturated, WATER Chemistry Fresh-Acid, soIL Mineral. Subordinate plants include beak rushes (Rhynchospora spp.), longleaf pine (Pinus palustris), orchids (Habenaria spp.), yellow-eyed grasses (Xyris spp.), grass pinks (Calopogon spp.), and foxtail clubmoss (Lycopodium alopecuroides). (Brunswick County, North Carolina; December 1975; Photo by V. Carter) 


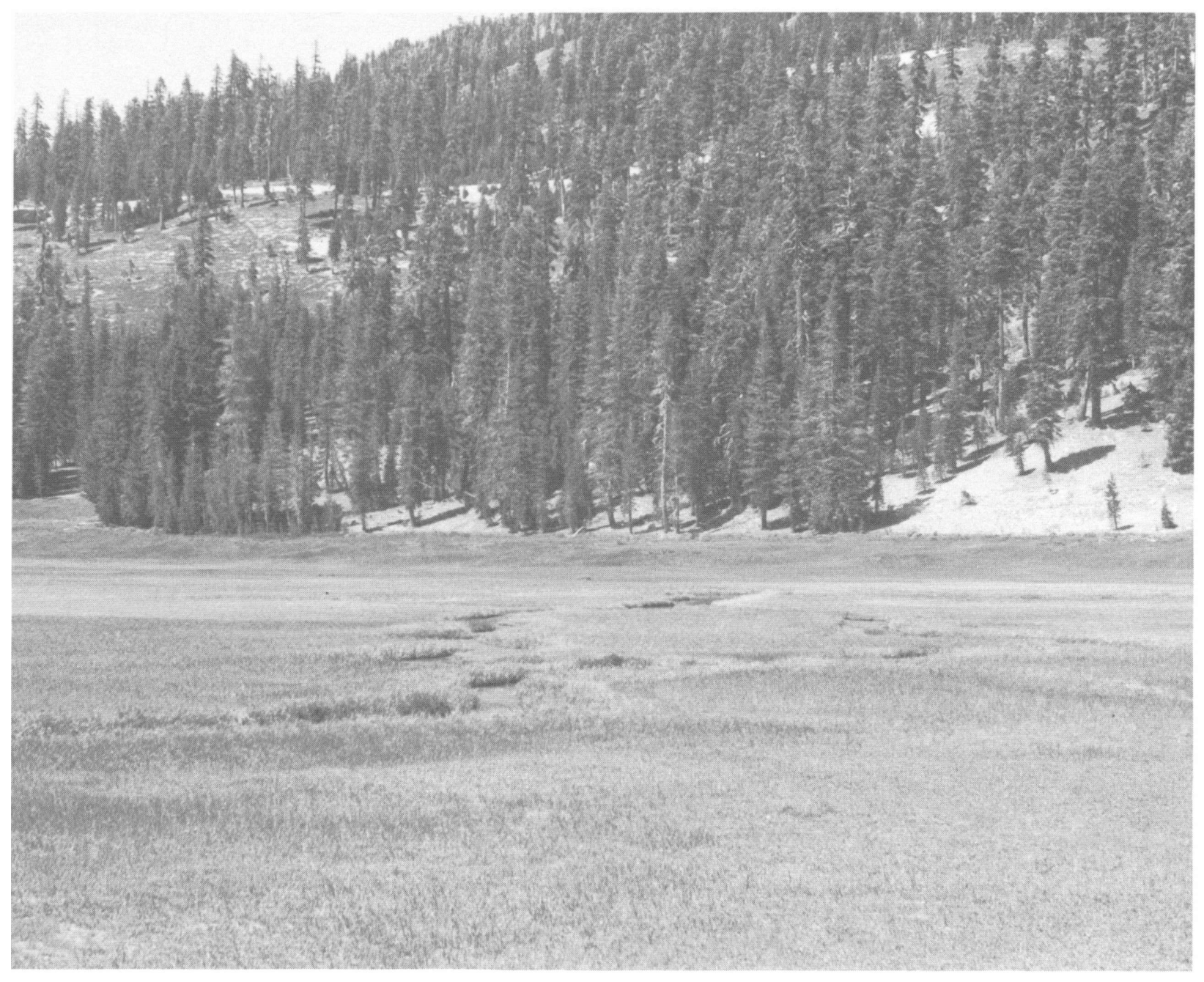

Plate 66.-Classification: SYSTEm Palustrine, Class Emergent Wetland, SUbClass Persistent, water REgime Saturated, water CHEMISTRY Fresh. The dominant plants in this montane meadow are sedges (Carex spp.). (Lassen County, California; August 1975; Photo by V. Carter) 


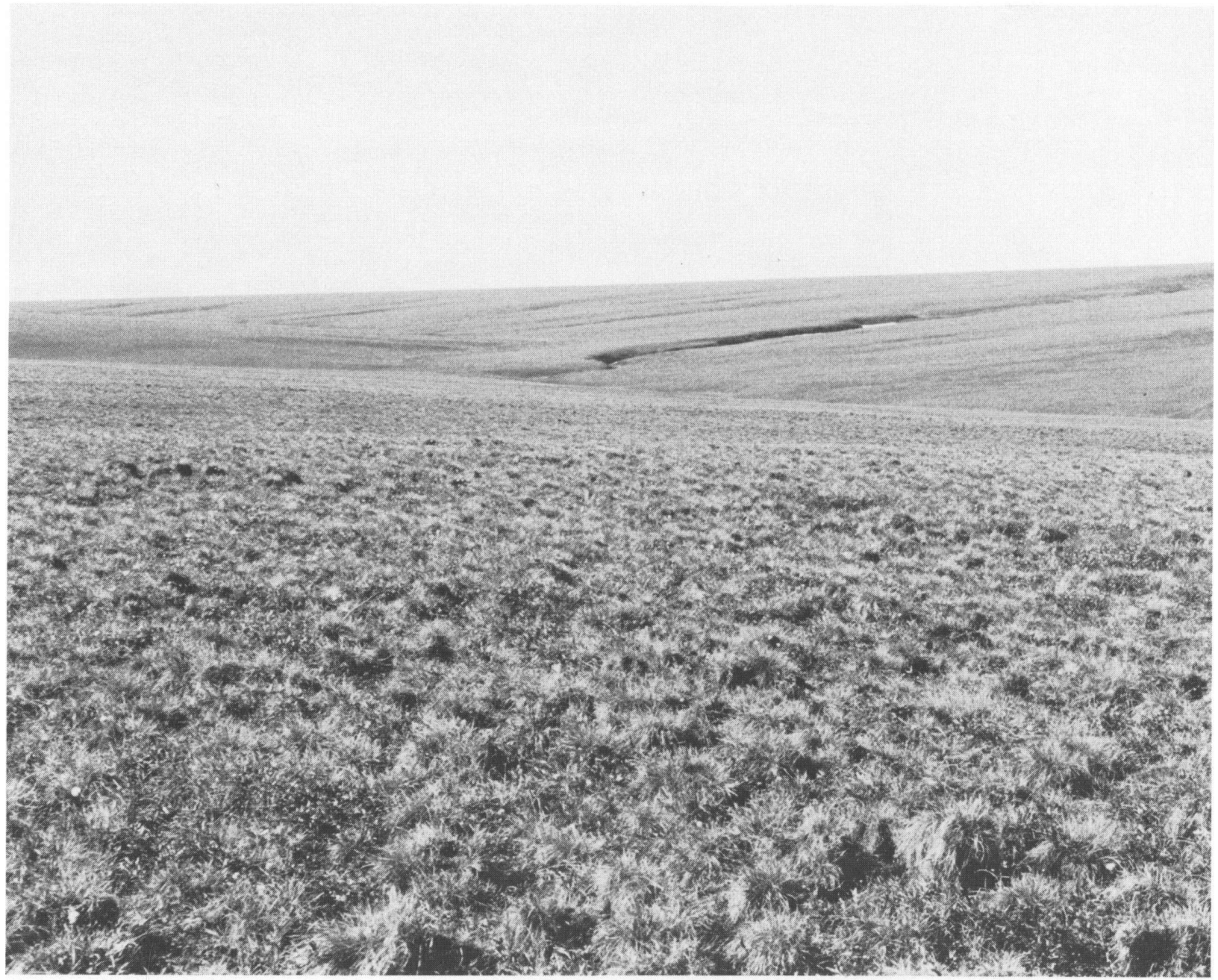

Plate 67.-Classification: system Palustrine, Class Emergent Wetland, sUbClass Persistent, DominaNCE TYPE Eriophorum vaginatum, WATER REGIME Saturated, WATER CHEMISTRY Fresh, soll Mineral. Subordinate plants include: netleaf willow (Salix reticulata), diamondleaf willow (S. planifolia), dryas (Dryas integrifolia), bistort ( Polygonum bistorta), lousewort (Pedicularis sp.), chickweed (Stellaria sp.), and lapland cassiope (Cassiope tetragona). This type of wetland, referred to by Walker (1983) as "moist tussock sedge dwarf shrub tundra," covers much of the North Slope of Alaska. At this site, permafrost lies within 15 $\mathrm{cm}$ (6 in) of the surface. All of the land in this photo is wetland. (Franklin Bluffs, North Slope Borough, Alaska; July 1985; Photo by F. C. Golet) 


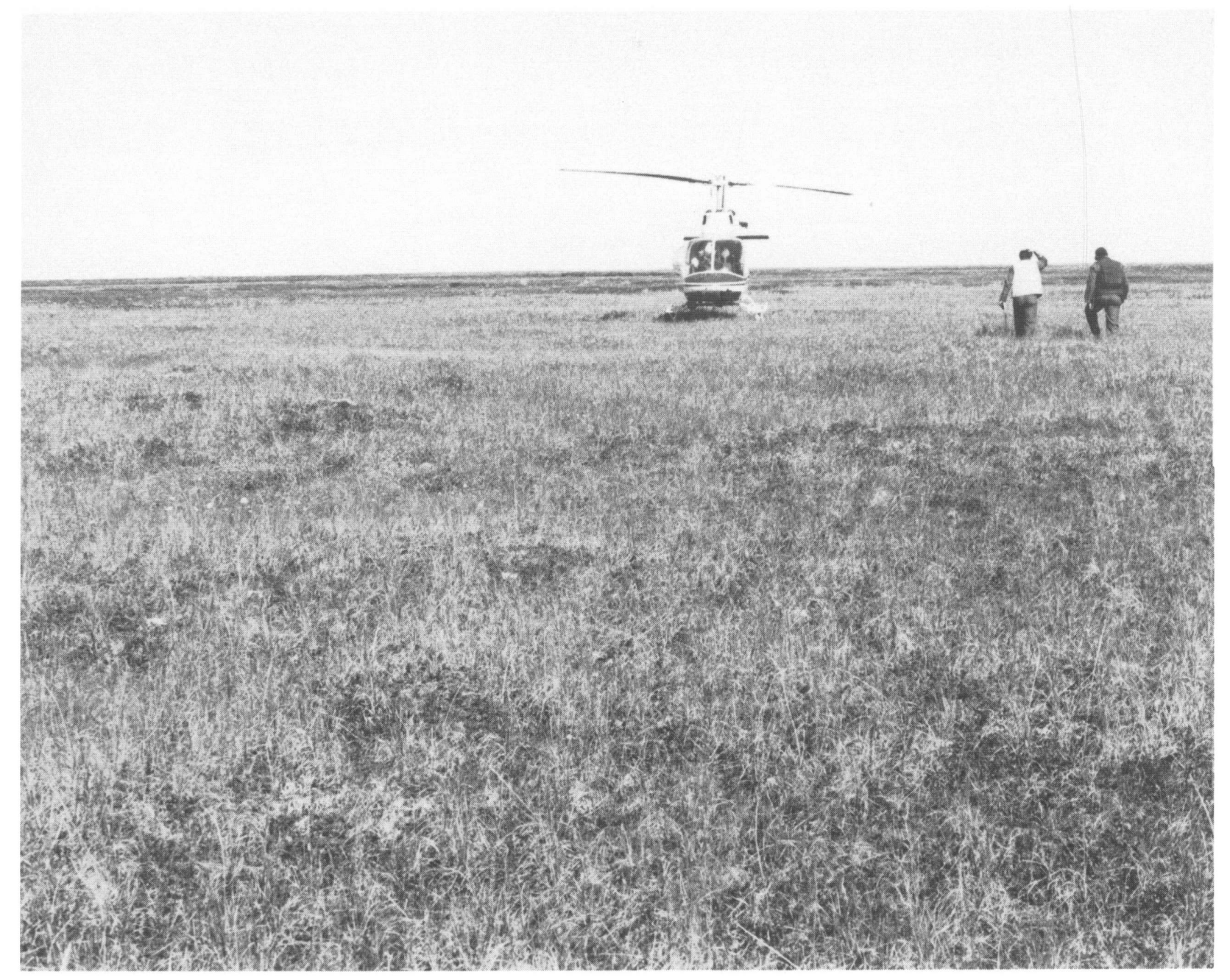

Plate 68.-Classification: SYsTem Palustrine, CLASs Emergent Wetland, sUBClass Persistent, DominaNCE TYPE Carex aquatilis, WATER REgIME Saturated, WATER CHEMISTRY Fresh. Subordinate plants include: narrowleaf Labrador tea (Ledum decumbens), dwarf birch (Betula nana), small cranberry (Vaccinium oxycoccos), crowberry (Empetrum nigrum), peat moss (Sphagnum spp.), and foliose lichens. (Narokachik River area, Yukon-Kuskokwim Delta, Alaska; July 1985; Photo by F. C. Golet) 


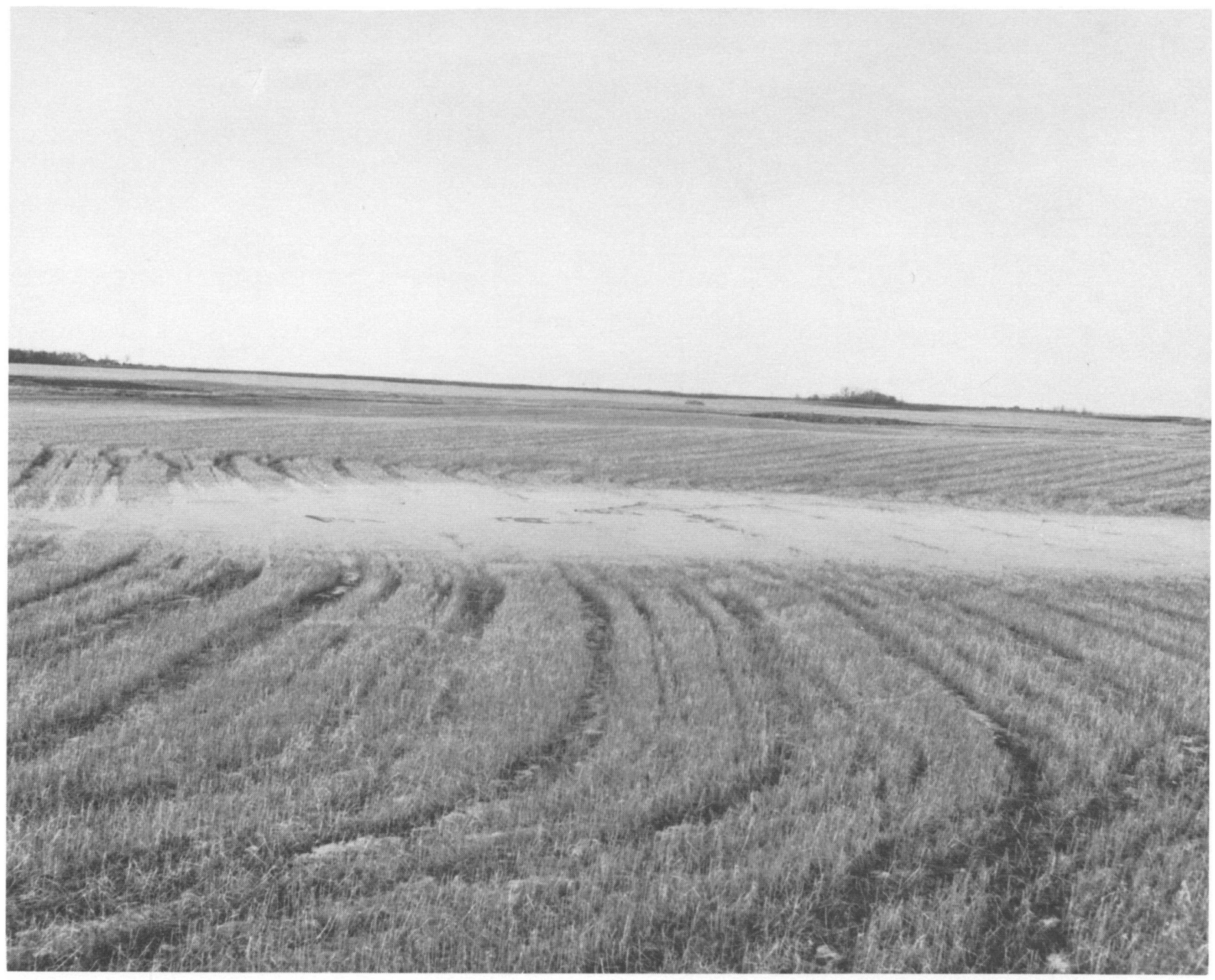

Plate 69.-Classification: system Palustrine, ClAss Emergent Wetland, subCLASS Persistent, water REgime Temporarily Flooded, WATER CHEMISTRY Oligosaline, soil Mineral, SPECIAL MODIFIER Farmed. All natural vegetation in this wetland has been removed, and water stands in stubble from the previous year's wheat crop. (Stutsman County, North Dakota; March 1967; Photo by H. A. Kantrud) 


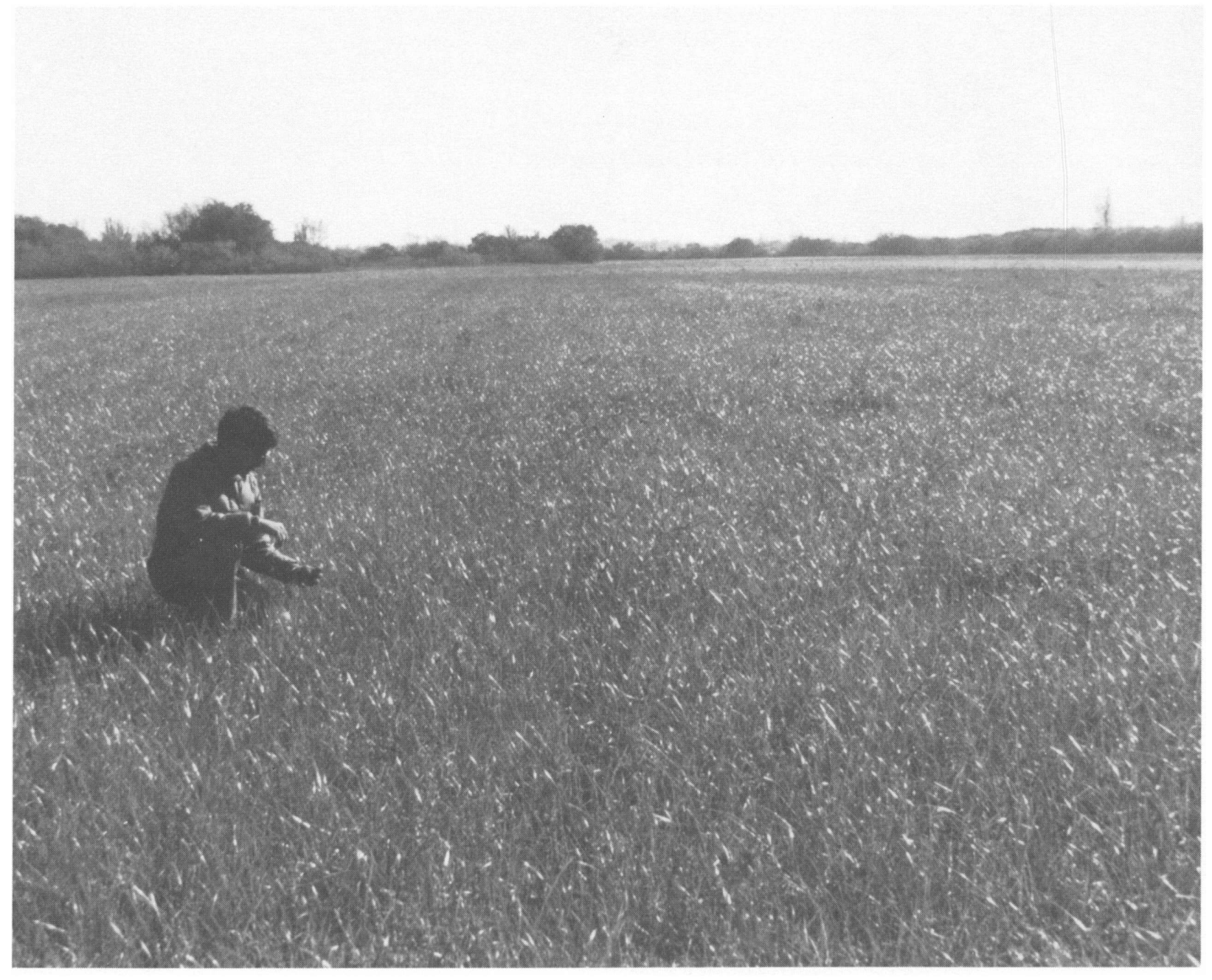

Plate 70.-Classification: SYSTEM Palustrine, CLASS Emergent Wetland, sUBCLASs Persistent, WATER REgime Temporarily Flooded, WATER CHEMISTRY Fresh, soIL Mineral, SPECIAL MODIFIER Farmed. Principal plants include nut sedge (Cyperus sp.), arrow arum (Peltandra virginica), and barnyard grass (Echinochloa crusgalli). (Dade County, Florida; January 1978; Photo by P. B. Reed) 


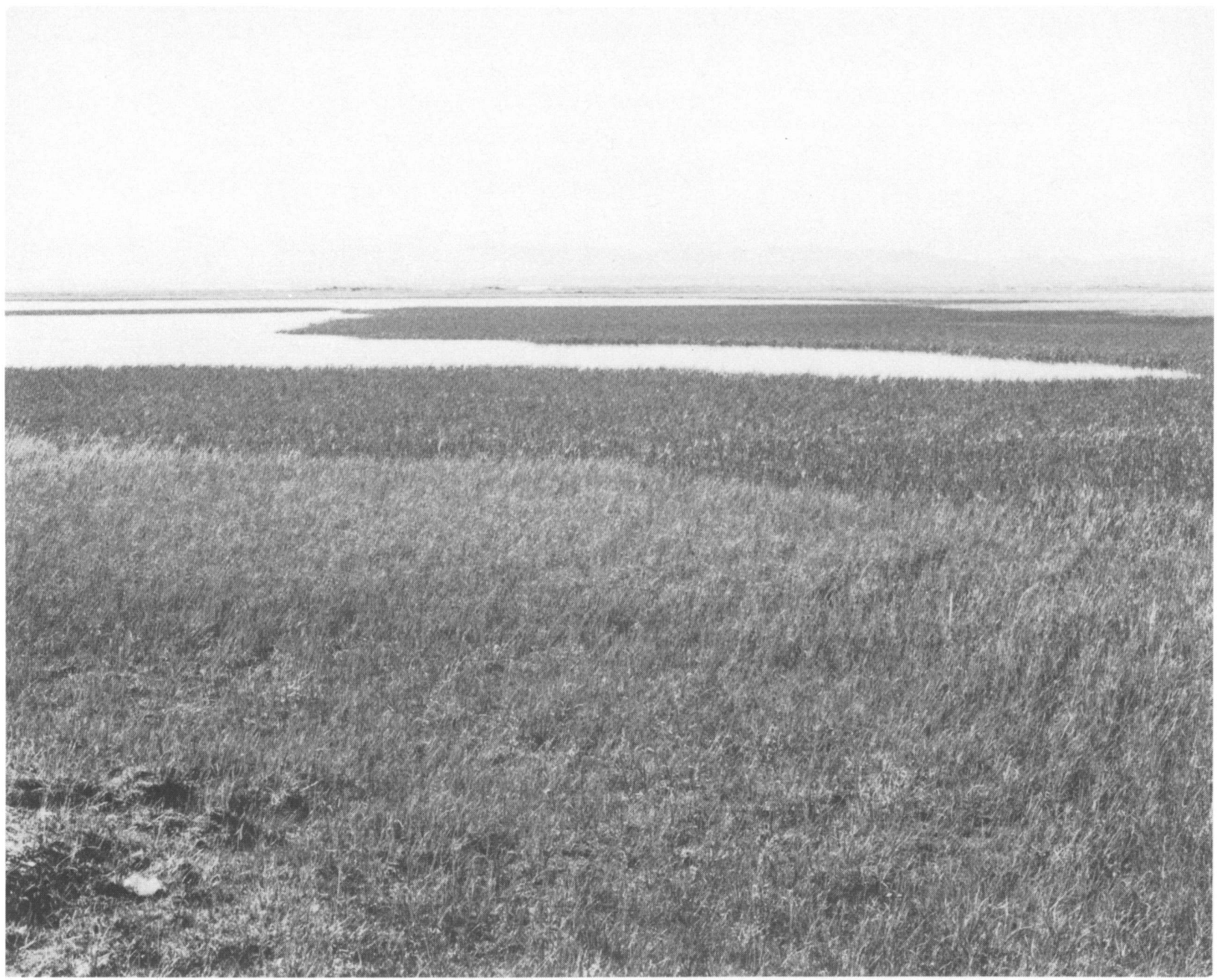

Plate 71.-Two habitats are shown here. Classification of darker zone (edge of water body): SYSTEM Palustrine, CLASS Emergent Wetland, SUBCLASs Nonpersistent, DOMINANCE TYPE Arctophila fulva, WATER REgIme Permanently Flooded, WATER CHEMISTRY Fresh. Classification of lighter zone (foreground): SYSTEM Palustrine, CLASs Emergent Wetland, sUBCLASs Persistent, DOMINANCE TYPE Carex aquatilis, WATER REgIME Seasonally Flooded, WATER CHEMISTRY Fresh. Marsh marigold (Caltha palustris) is also present in the seasonally flooded zone. This wetland lies on coastal tundra within $2 \mathrm{~km}(1.2 \mathrm{mi})$ of the Arctic Ocean. (Between Canning and Kavik Rivers, North Slope Borough, Alaska; July 1985; Photo by F. C. Golet) 


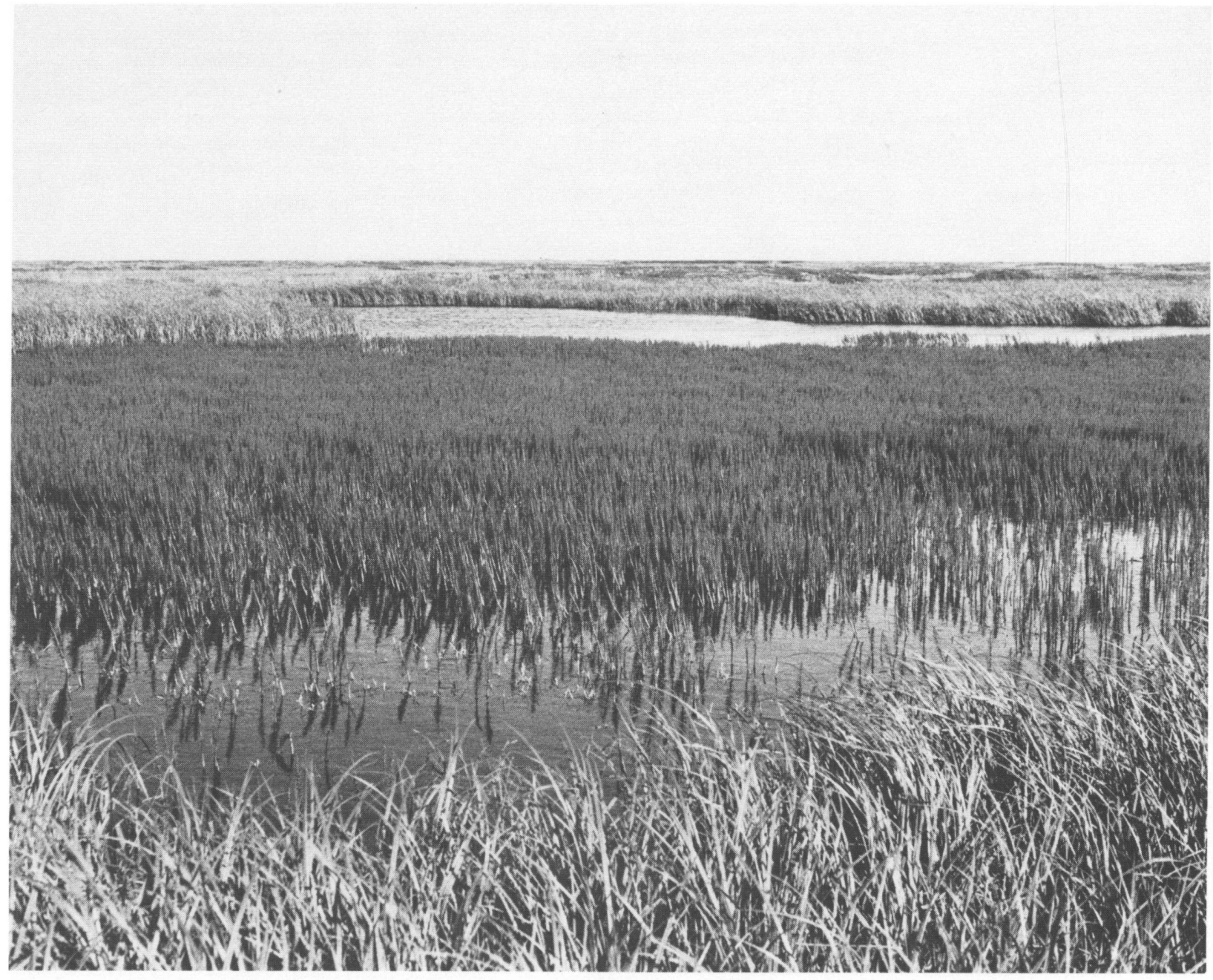

Plate 72.-Classification: SYSTEM Palustrine, CLASS Emergent Wetland, sUBCLASS Nonpersistent, DOMINANCE TYPE Hippuris tetraphylla, WATER REgIme Permanently Flooded, water Chemistry Fresh. A semipermanently flooded persistent-emergent wetland dominated by sedge (Carex lyngbyei) surrounds the Hippuris marsh. Burreed (Sparganium hyperboreum) grows in shallow water between the Hippuris and the sedges. (Narokachik River area, Yukon-Kuskokwim Delta, Alaska; July 1985; Photo by F. C. Golet) 


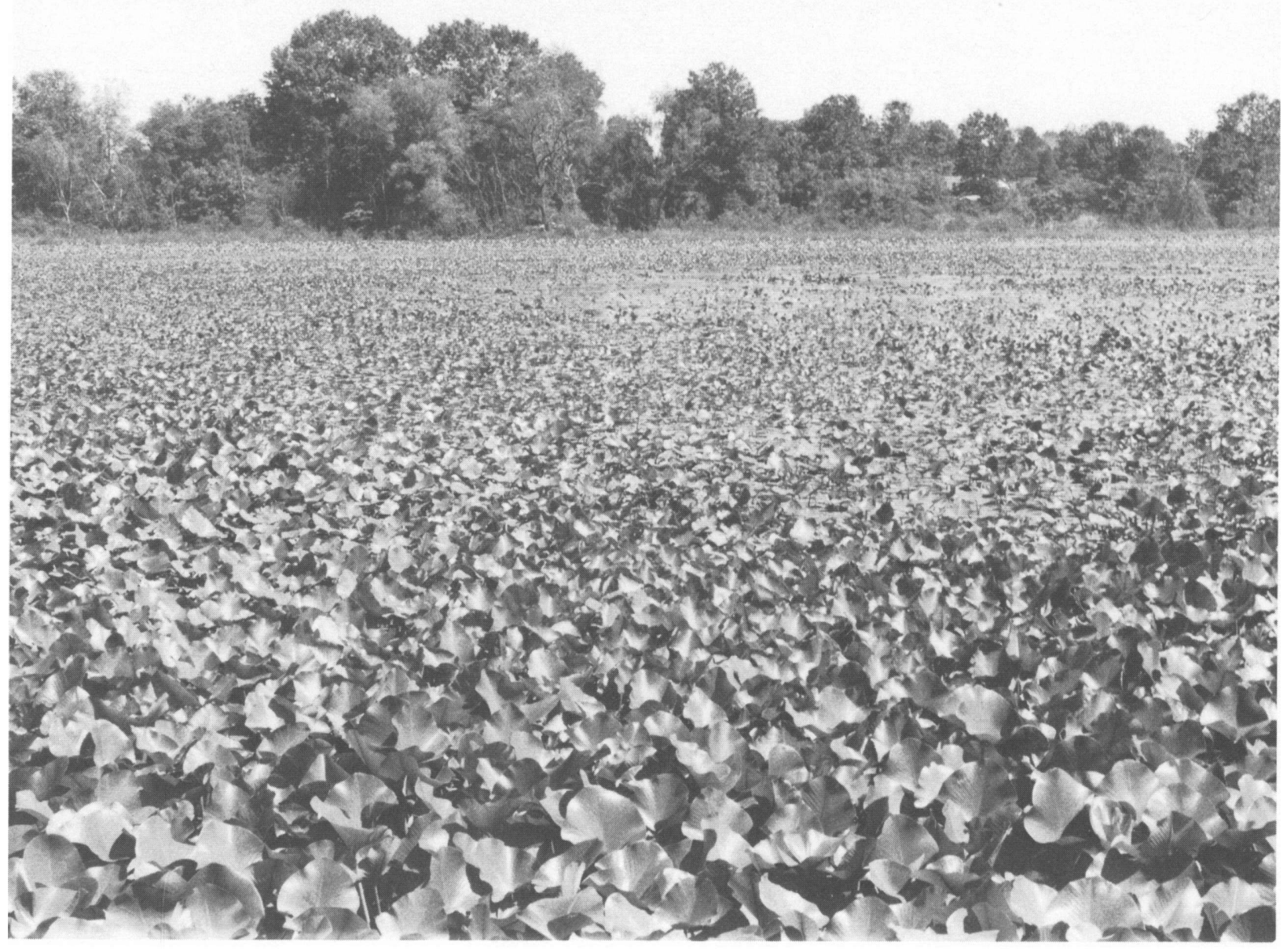

Plate 73.-Classification: SYSTEM Palustrine, CLASS Emergent Wetland, SUBCLASS Nonpersistent, DOMINANCE TYPE Nuphar luteum, WATER REGIME Semipermanently Flooded, wATER CHEMISTRY Fresh. The principal subordinate plant is common duckweed (Lemna minor). (Cass County, Michigan; May 1985; Photo by F. C. Golet) 


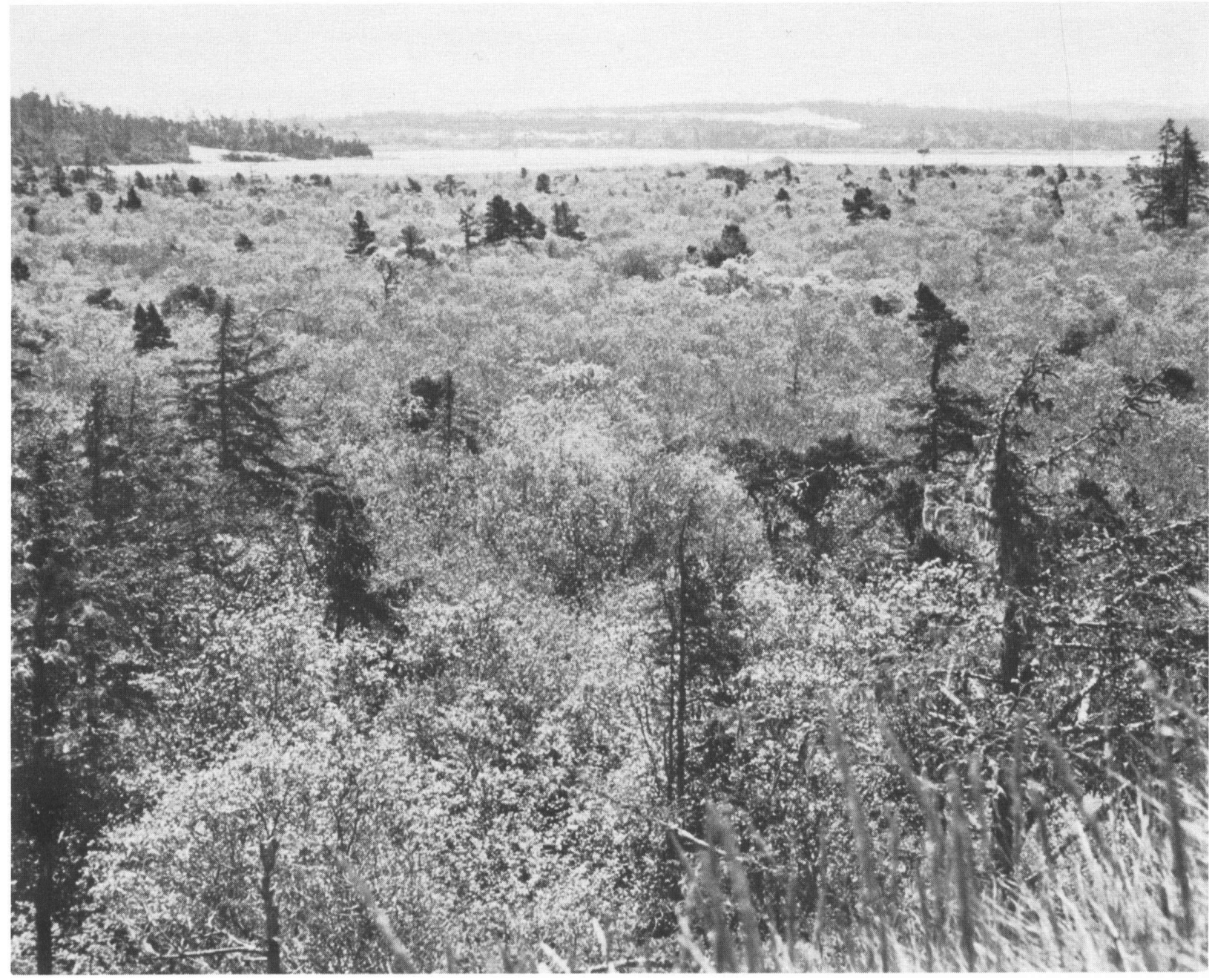

Plate 74.-Classification: SySTEM Palustrine, Class Scrub-Shrub Wetland, sUbCLASs Broad-leaved Deciduous, water REgIME Seasonally Flooded, WATER CHEMISTRY Fresh-Acid, soIL Organic. The dominant plants are willows (Salix spp.). Subordinate species include Sitka spruce (Picea sitchensis) and lodgepole pine (Pinus contorta). (Coos County, Oregon; May 1977; Photo by D. D. Peters) 


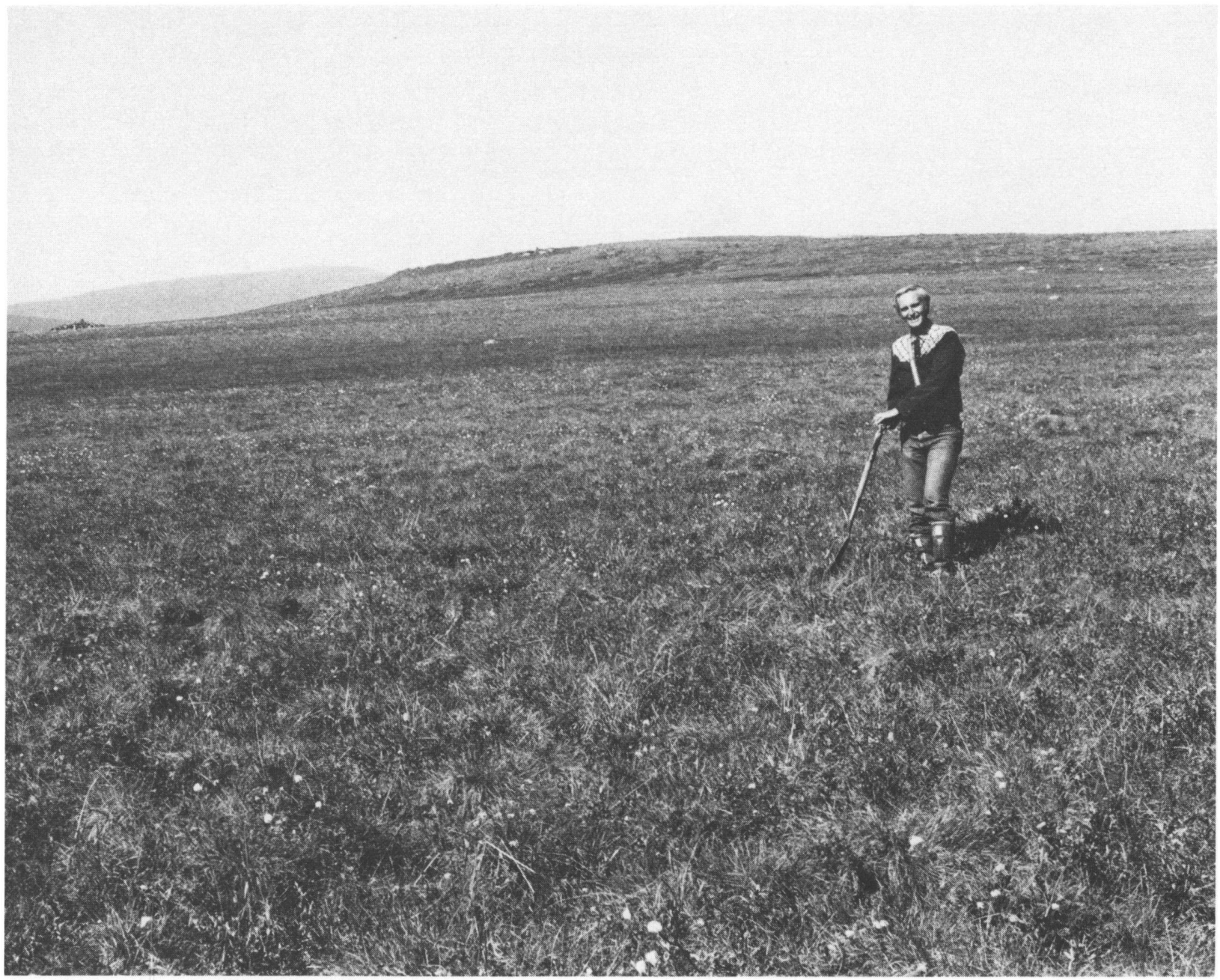

Plate 75.-Classificaton: SYSTEM Palustrine, CLASS Scrub-Shrub Wetland, sUBCLASS Broad-leaved Deciduous, DOMINANCE TYPE Betula nana, water REgime Saturated, water Chemistry Fresh, soll Mineral. Subordinate plants include cotton grass (Eriophorum vaginatum), peat moss (Sphagnum spp.), cloudberry (Rubus chamaemorus), mountain cranberry (Vaccinium vitisidaea), and narrowleaf Labrador tea (Ledum decumbens). Shrubs here are less than $20 \mathrm{~cm}(8 \mathrm{in})$ tall. This area of moist tundra is underlain by permafrost at a depth of $45 \mathrm{~cm}$ (18 in). (Vicinity of Toolik Lake, North Slope Borough, Alaska; July 1985; Photo by F. C. Golet) 


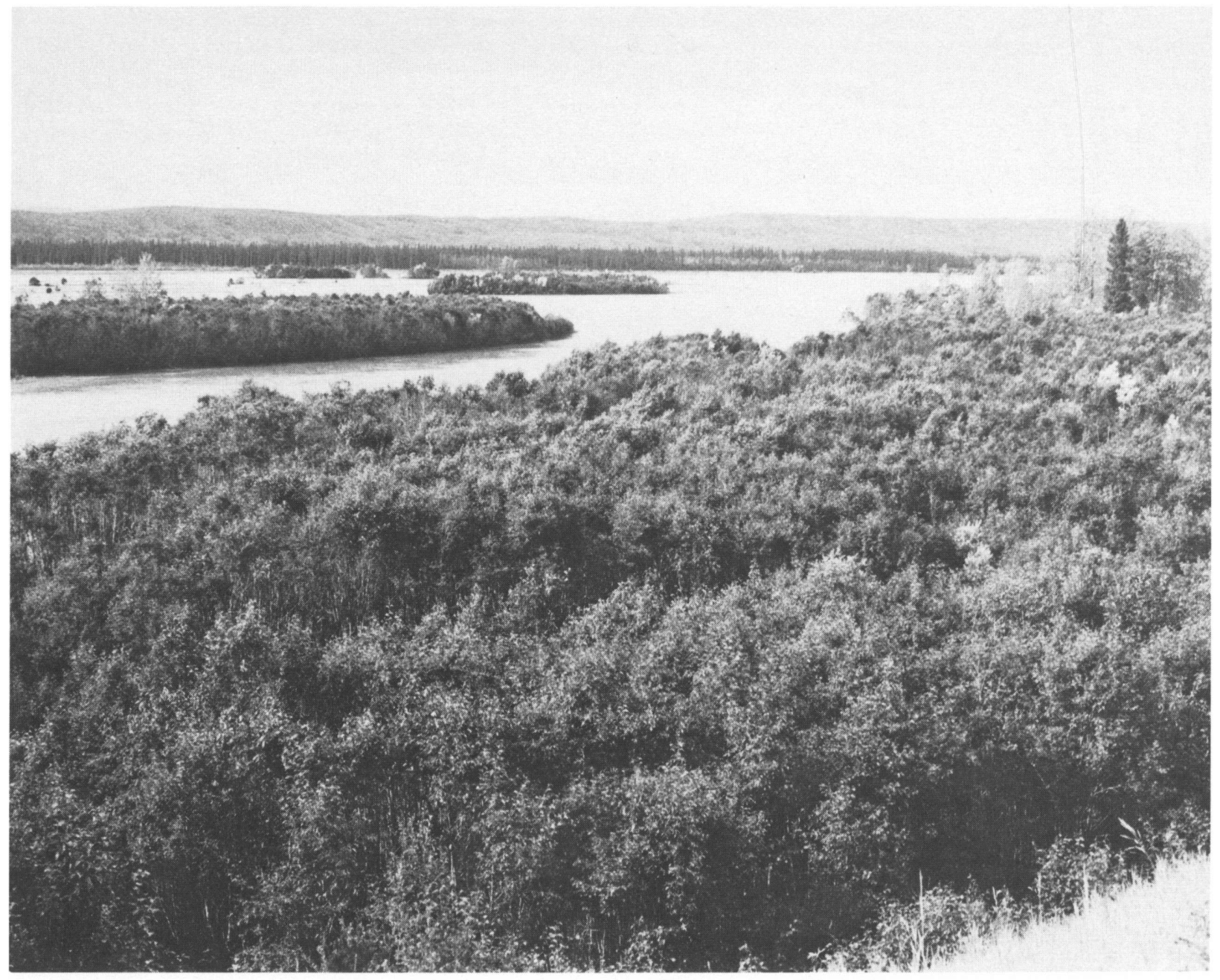

Plate 76.-Classification: SYSTEM Palustrine, CLASS Scrub-Shrub Wetland, sUBCLASS Broad-leaved Deciduous, DOMINANCE TYPE Alnus tenuifolia, wATER REgIME Temporarily Flooded, WATER chemiSTRY Fresh, soIL Mineral. Subordinate plants include feltleaf willow (Salix alaxensis) and balsam poplar (Populus balsamifera). Shrubs are nearly $6 \mathrm{~m}$ (20 ft) tall, the height that separates Scrub-Shrub from Forested Wetland. This site is flooded only for brief periods after snowmelt and during times of most rapid melting of nearby glaciers. (Tanana River, Fairbanks North Star Borough, Alaska; July 1985; Photo by F. C. Golet) 


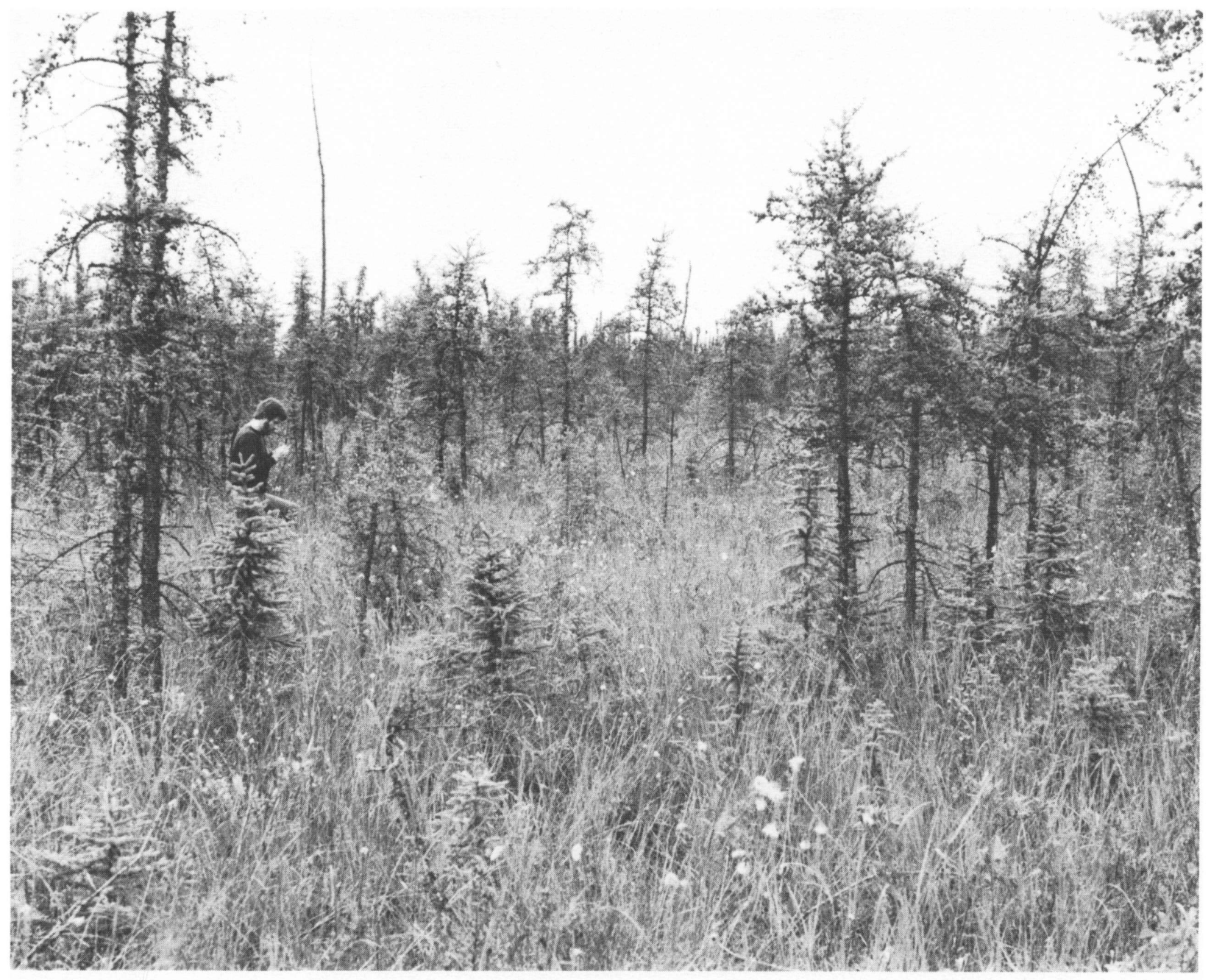

Plate 77.-Classification: SYSTEM Palustrine, CLASS Scrub-Shrub Wetland, SUBCLASs Needle-leaved Deciduous, DOMINANCE TYPE Larix laricina, WATER REGIME Seasonally Flooded, WATER CHEMISTRY Fresh. The tamarack saplings are 2-3 m (6.6-10 ft) tall and cover $40-45 \%$ of the site. Subordinate plants include: dwarf birch (Betula nana), bluejoint (Calamagrostis canadensis), black spruce (Picea mariana), leatherleaf (Chamaedaphne calyculata), diamondleaf willow (Salix planifolia), narrowleaf Labrador tea (Ledum decumbens), cotton grass (Eriophorum sp.), bog blueberry (Vaccinium uliginosum), marsh cinquefoil (Potentilla palustris), and shrubby cinquefoil (P. fruticosa). (Vicinity of Big Delta, Alaska; July 1985; Photo by F. C. Golet) 


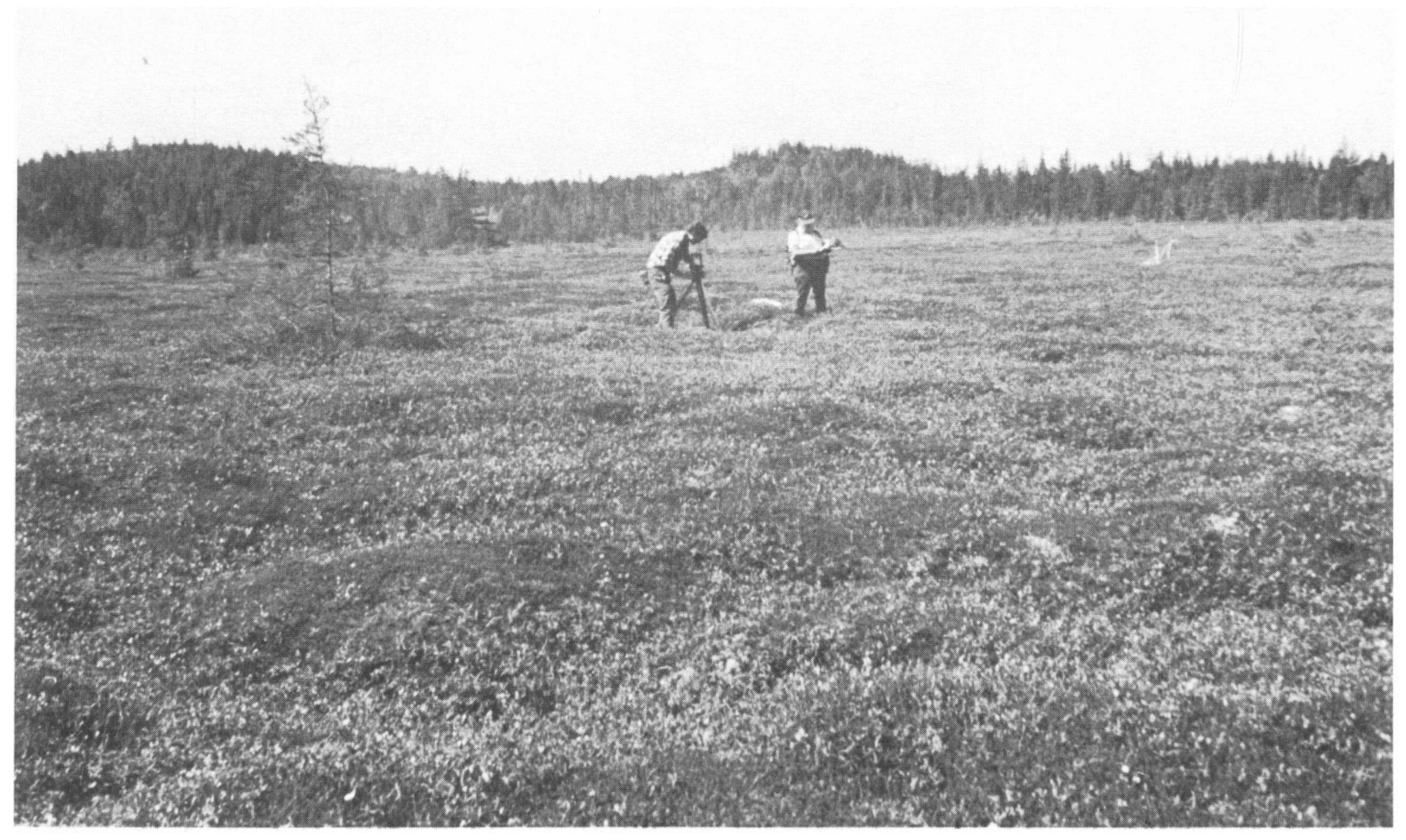

Plate 78.-Classification: SYSTEM Palustrine, CLASs Scrub-Shrub Wetland, sUBCLASs Broad-leaved Evergreen, DOMINANCE TYPE Ledum groenlandicum-Kalmia angustifolia-Chamaedaphne calyculata, WATER REGIME Saturated, WATER CHEMISTRY FreshAcid, soll Organic. Subordinate plants include peat moss (Sphagnum spp.), crowberry (Empetrum nigrum), cloudberry (Rubus chamaemorus), and black spruce (Picea mariana). (Washington County, Maine; June 1976; Photo by V. Carter) 


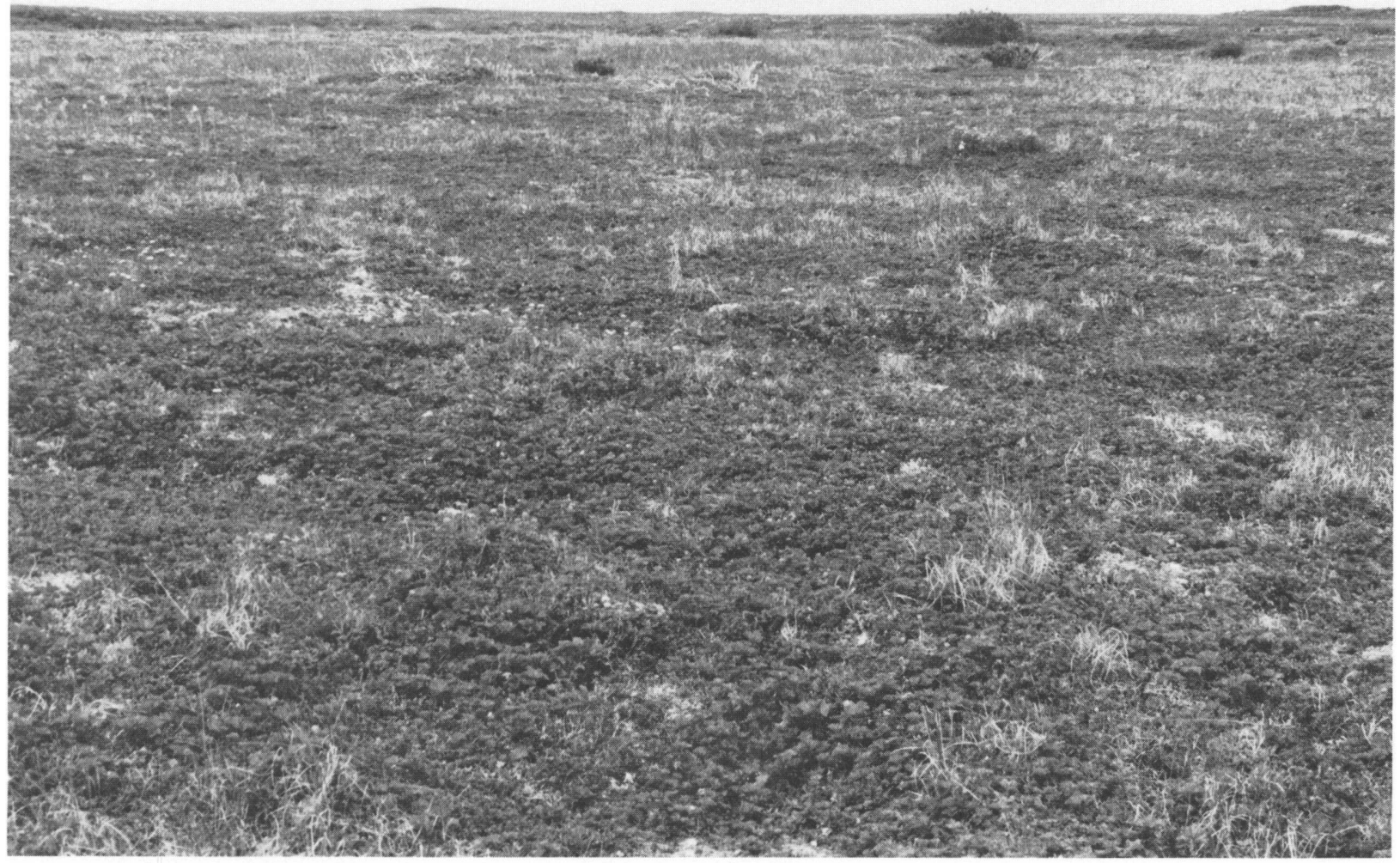

Plate 79.-Classification: SYSTEM Palustrine, CLASS Scrub-Shrub Wetland, subCLASs Broad-leaved Evergreen, DOMINANCE TYPE Ledum decumbens, wATER REgIme Saturated, WATER CHEMISTRY Fresh, soIL Mineral. Subordinate species include: cloudberry (Rubus chamaemorus), mountain cranberry (Vaccinium vitis-idaea), crowberry (Empetrum nigrum), dwarf birch (Betula nana), reindeer moss (Cladina spp.), sedge (Carex aquatilis), bluejoint (Calamagrostis canadensis), and Alaska spiraea (Spiraea beauverdiana). Shrubs are less than $20 \mathrm{~cm}$ (8 in) tall. Although this site looks like a dry heath, permafrost at a depth of only 15-20 cm (6-8 in) keeps the soil saturated near the surface throughout the growing season. (Talik River area, Yukon-Kuskokwim Delta, Alaska; July 1985; Photo by F. C. Golet) 


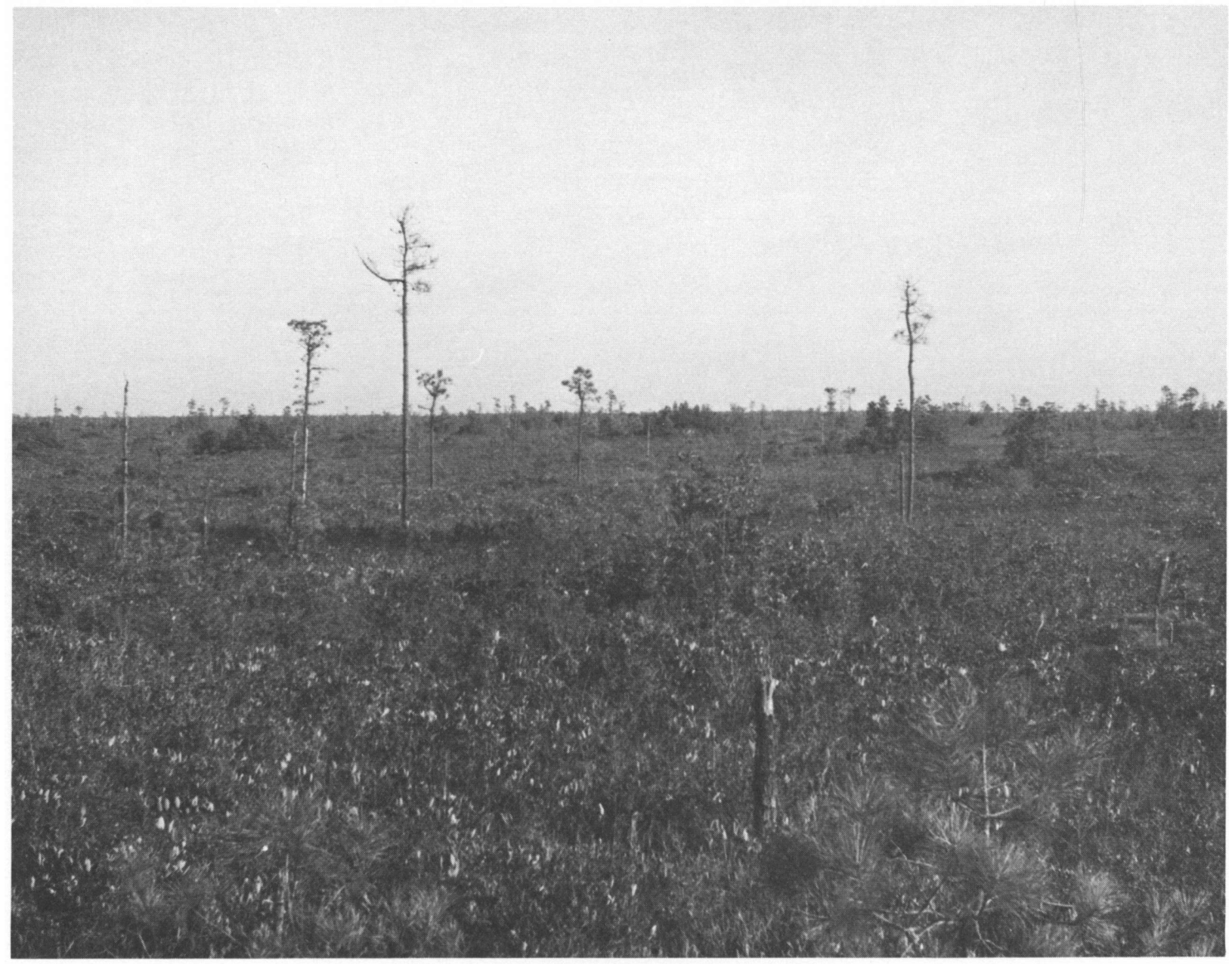

Plate 80.-Classification: SYSTEM Palustrine, CLASS Scrub-Shrub Wetland, sUBCLASS Broad-leaved Evergreen, DOMINANCE TYPE Cyrilla racemiflora, WATER REGIME Saturated, WATER CHEMISTRY Fresh-Acid, soll Organic. Subordinate plants include: honeycup (Zenobia pulverulenta), leatherleaf (Chamaedaphne calyculata), peat moss (Sphagnum spp.), highbush blueberry (Vaccinium corymbosum), loblolly bay (Gordonia lasianthus), pond pine (Pinus serotina), and highbush blueberry (Vaccinium corymbosum). Locally, these wetlands are referred to as evergreen shrub bogs or "pocosins." (Brunswick County, North Carolina; December 1975; Photo by V. Carter) 


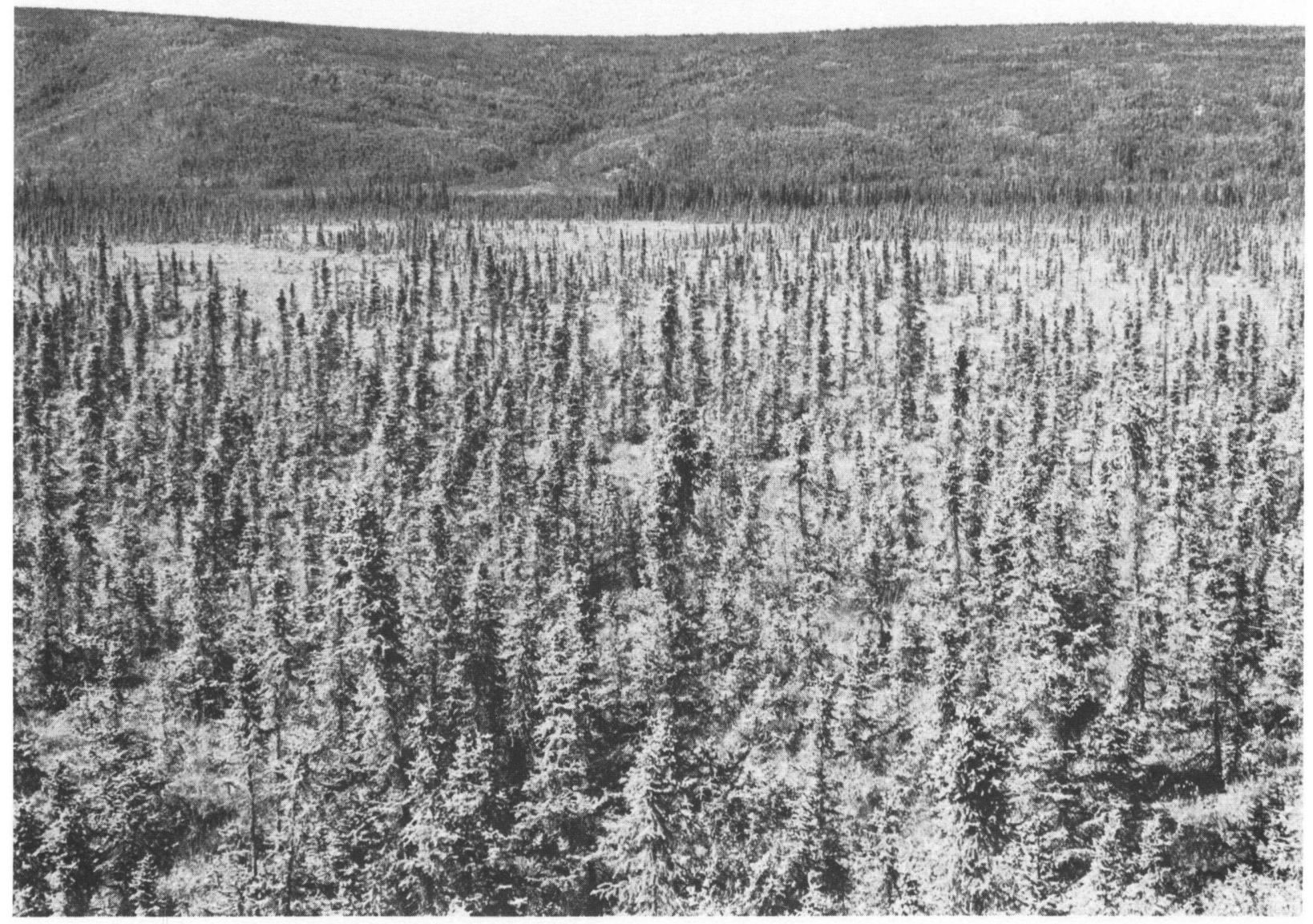

Plate 81.-Classification: SYSTEM Palustrine, CLASS Scrub-Shrub Wetland, SUBCLASs Needle-leaved Evergreen, DOMINANCE TYPE Picea mariana, WATER REgIME Saturated, WATER CHEMISTRY Fresh. Subordinate plants include: dwarf birch (Betula nana), cotton grass (Eriophorum vaginatum), bog blueberry (Vaccinium uliginosum), Labrador tea (Ledum groenlandicum), and peat moss (Sphagnum spp.). This wetland type, commonly known as "muskeg," is abundant in the forested regions of Alaska; it also occurs in northern New England and in the Great Lakes States. (Vicinity of Coldfoot, Alaska; July 1985; Photo by F. C. Golet) 


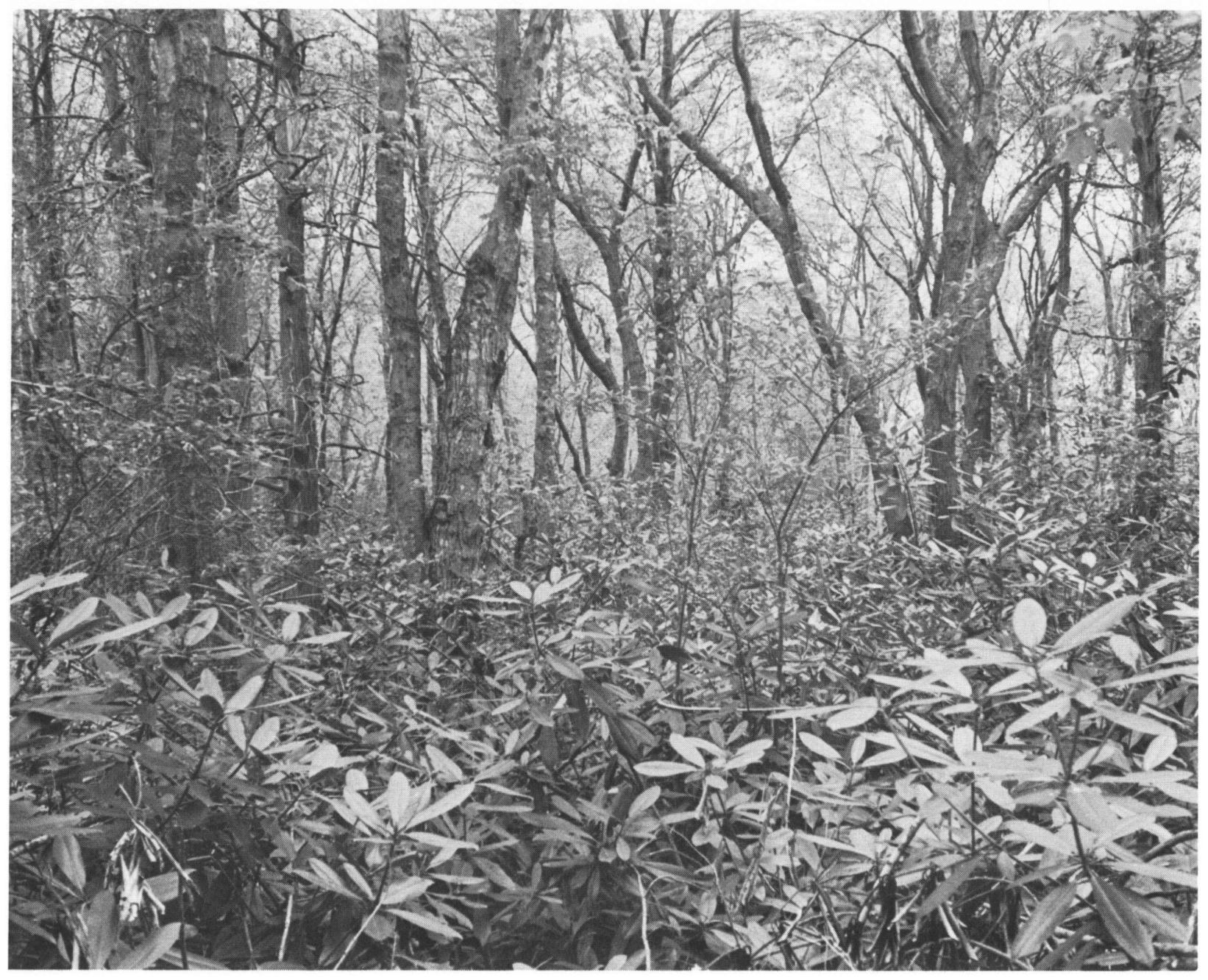

Plate 82.-Classification: SYSTEM Palustrine, CLASS Forested Wetland, subCLASs Broad-leaved Deciduous, DOMINANCE TYPE Acer rubrum, WATER REgIMe Saturated, WATER CHEMISTRY Fresh-Acid, soIL Organic. Subordinate plants in this red maple swamp include black gum (Nyssa sylvatica), highbush blueberry (Vaccinium corymbosum), great laurel (Rhododendron maximum), and winterberry (Ilex verticillata). (Washington County, Rhode Island; June 1977; Photo by F. C. Golet) 


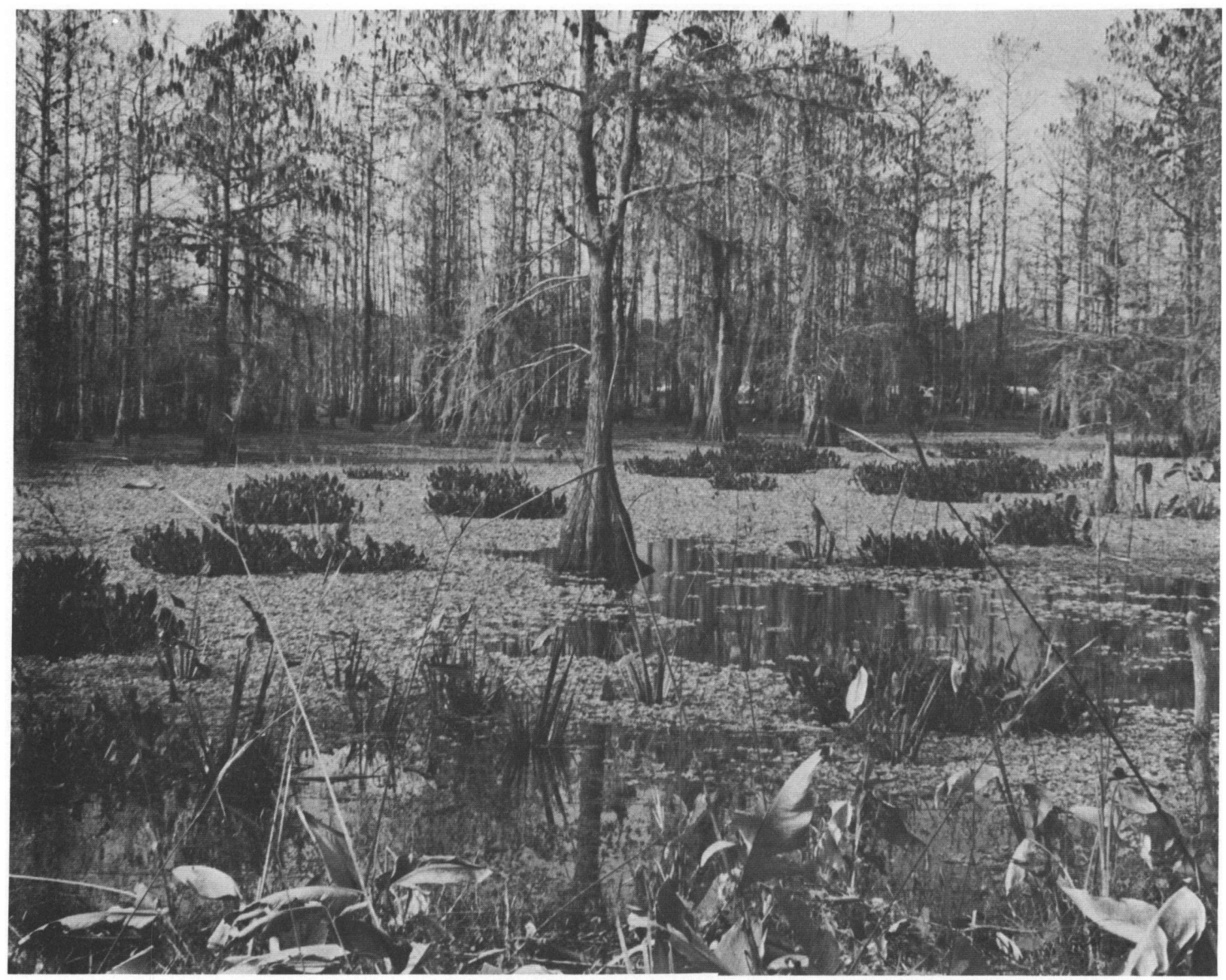

Plate 83.-Two habitats are shown here. Classification of the forested area: SYSTEM Palustrine, CLASs Forested Wetland, SUBCLASS Needle-leaved Deciduous, DOMINANCE TYPE Taxodium distichum, WATER REgIME Permanently Flooded, WATER CHEMISTRY Fresh. Classification of the open area: SYSTEM Palustrine, Class Aquatic Bed, subClass Floating Vascular, DOMINANCE TYPE Pistia stratiotes, WATER REGIME Permanently Flooded, WATER CHEMISTRY Fresh. Emergent plants growing in the bed of water lettuce are arrowheads (Sagittaria spp.). (Corkscrew Swamp Sanctuary, Collier County, Florida; January 1978; Photo by E. T. LaRoe) 


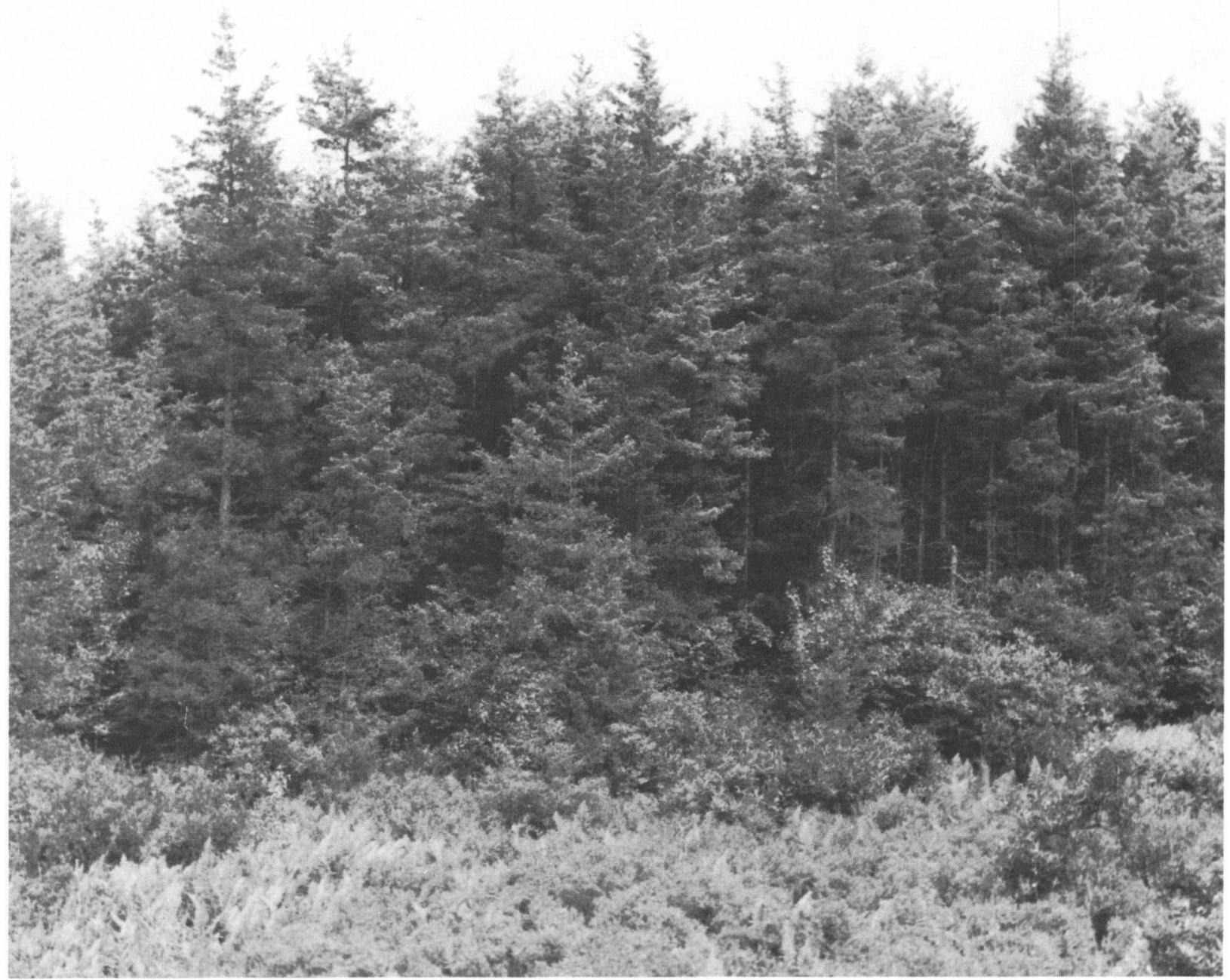

Plate 84.-Classification: SYSTEM Palustrine, cLASS Forested Wetland, sUBCLASS Needle-leaved Evergreen, DOMINANCE TYPE Chamaecyparis thyoides, WATER REGIME Seasonally Flooded, WATER CHEMISTRY Fresh-Acid, soll Organic. Subordinate plants in this Atlantic white cedar swamp include: highbush blueberry (Vaccinium corymbosum), winterberry (Ilex verticillata), red maple (Acer rubrum), and peat moss (Sphagnum spp.). Low vegetation in the foreground includes leatherleaf (Chamaedaphne calyculata) and Virginia chain-fern (Woodwardia virginica). (Washington County, Rhode Island; July 1977; Photo by F. C. Golet) 


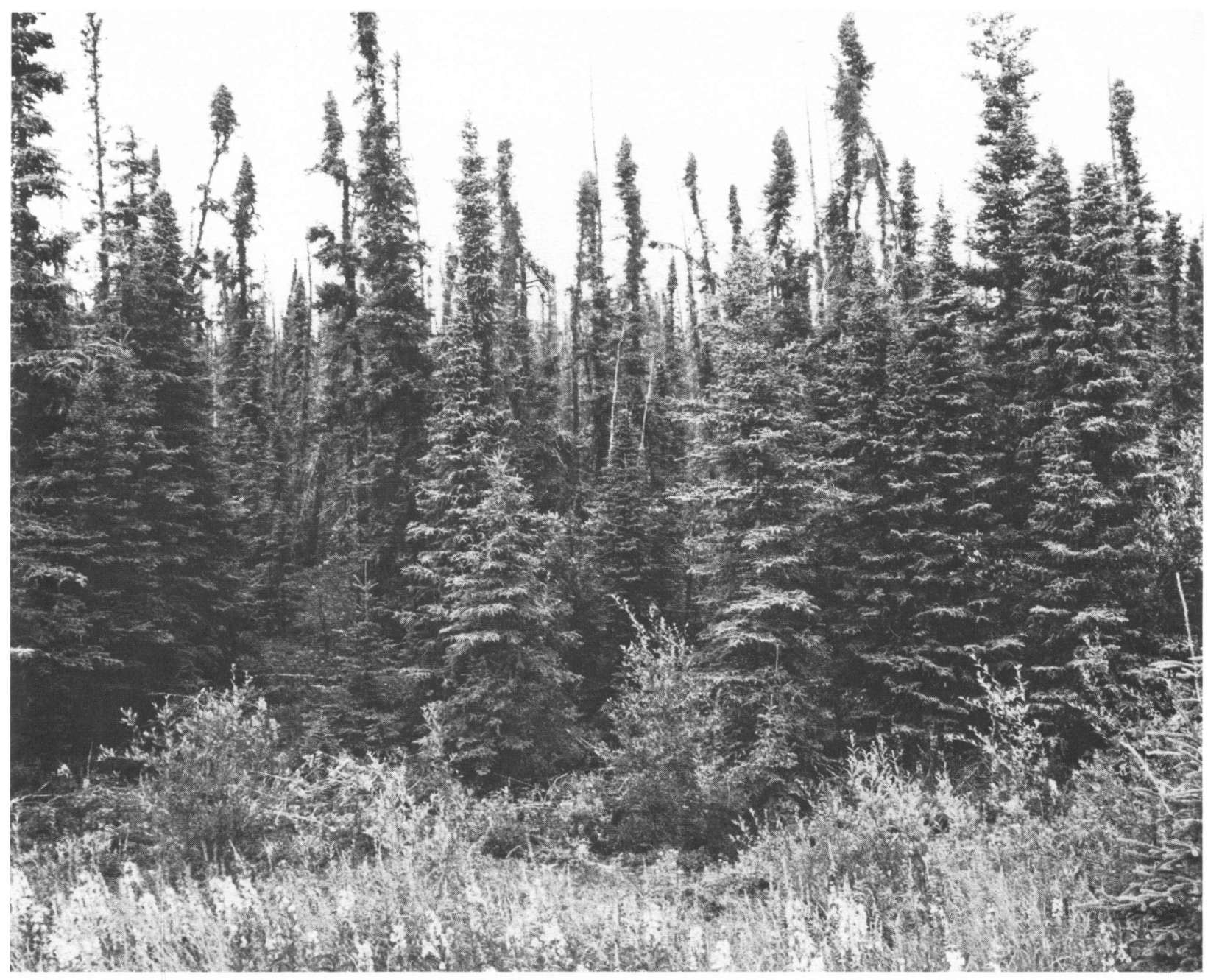

Plate 85.-Classification: SYSTEM Palustrine, CLASS Forested Wetland, sUBCLASs Needle-leaved Evergreen, DOMINANCE TYPE Picea mariana, WATER REgIme Saturated, WATER CHEMISTRY Fresh, soIL Mineral. Subordinate plants in this black spruce forest include Labrador tea (Ledum groenlandicum), mountain cranberry (Vaccinium vitis-idaea), crowberry (Empetrum nigrum), and peat moss (Sphagnum sp.). Permafrost is present within $45 \mathrm{~cm}$ (18 in) of the surface. (Vicinity of Glennallen, Alaska; July 1985 ; Photo by F. C. Golet) 


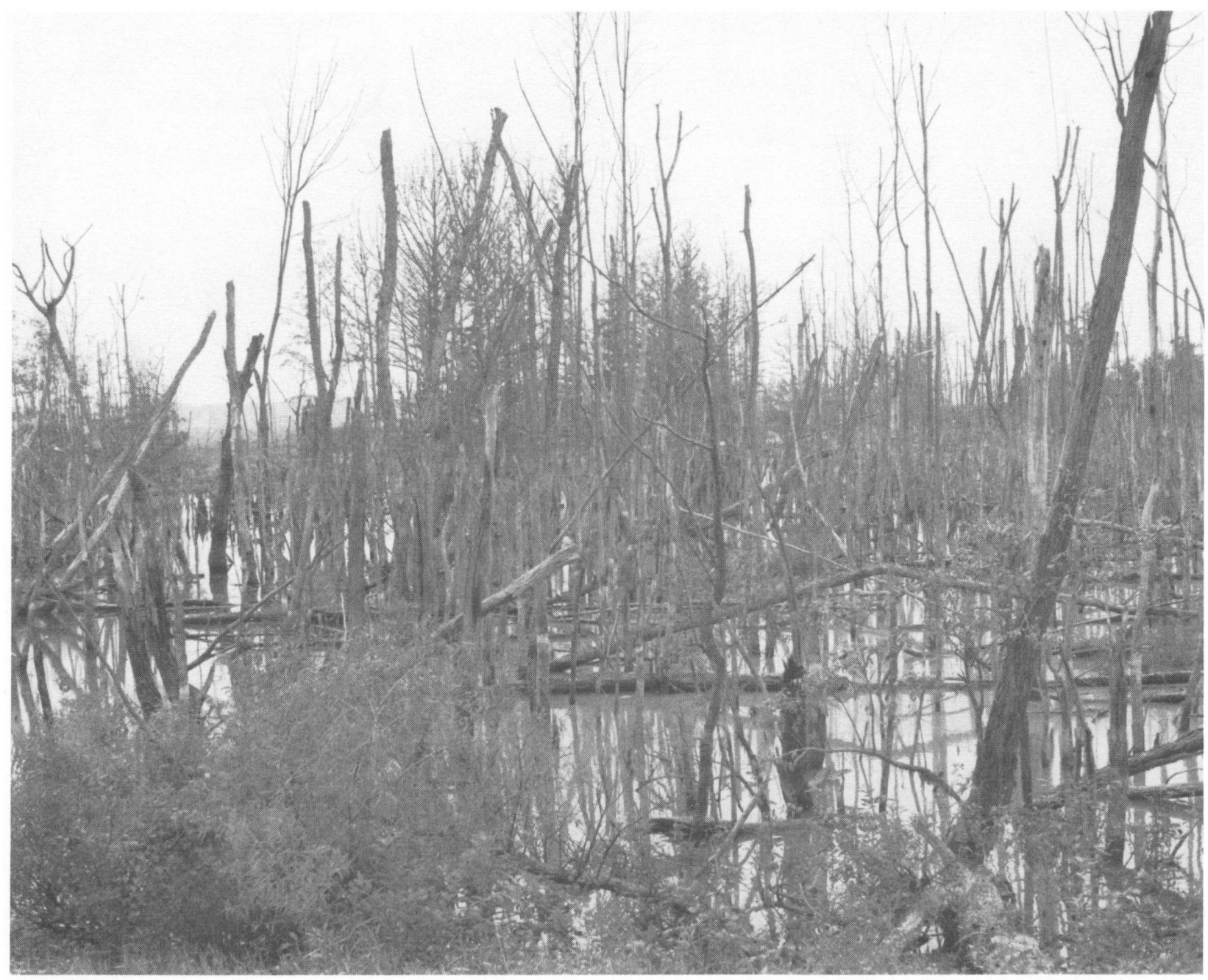

Plate 86.-Classification: System Palustrine, Class Forested Wetland, subClass Dead, Water REgime Permanently Flooded, WATER CHEMISTRY Fresh-Circumneutral, soll Mineral, sPECLAL MODIFIER Impounded. (Humphreys County, Tennessee; September 1975; Photo by V. Carter) 





\section{WETLANDS AND DEEPWATER HABITATS CLASSIFICATION}

SYSTEM

SUBSYSTEM

class

Subclass

SYSTEM

class

subciess:

\section{L - LACUSTRINE}

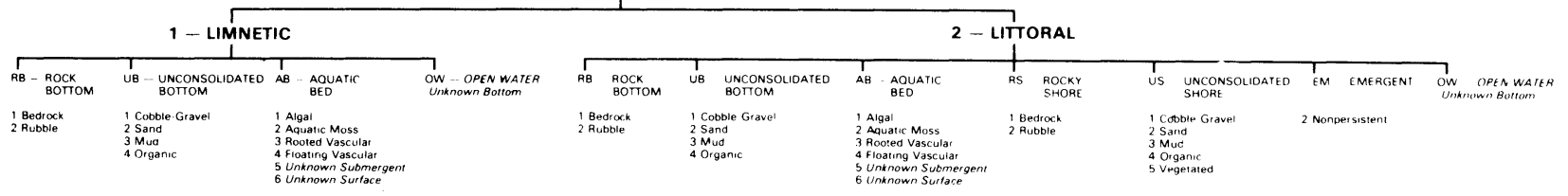

P- PALUSTRINE

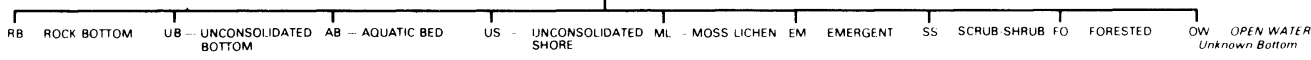

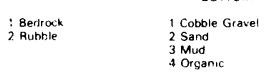

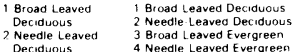

$\begin{array}{ll}1 \text { Moss } & 1 \text { Peesistient } \\ 2 \text { Lichen } & 2 \text { Nonpersistent }\end{array}$

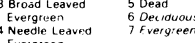

MODIFIERS

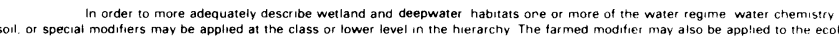

\begin{tabular}{|c|c|c|c|c|c|c|c|c|}
\hline \multicolumn{3}{|c|}{ WATER REGIME } & \multicolumn{3}{|c|}{ WATER CHEMISTRY } & \multirow{3}{*}{$\begin{array}{ll}\text { SOIL } \\
\end{array}$} & \multicolumn{2}{|c|}{ SPECIAL MODIFIERS } \\
\hline Non & -Tidal & Tidat & Coastal Halinity & Inland Salinity & pH Modifiers for & & & \\
\hline 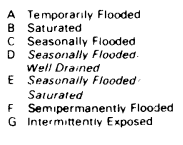 & 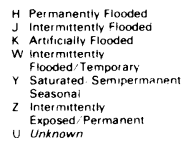 & 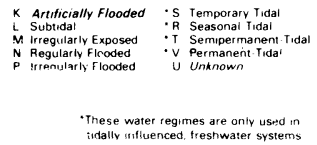 & $\begin{array}{l}1 \text { Hyperhaline } \\
2 \text { Euhaline } \\
3 \text { Mixonaline (Brackish) } \\
4 \text { Polvhaline } \\
5 \text { Mesoliline } \\
6 \text { Otgohaline } \\
\text { 0 Fresh }\end{array}$ & $\begin{array}{l}7 \text { Hypersaline } \\
8 \text { Eussline } \\
9 \text { Mixosalitie } \\
\text { O Fresh } \\
\end{array}$ & $\begin{array}{l}\text { all Fresh Water } \\
\text { a Acid } \\
\text { i Circumneutral } \\
\text { i Alkatine }\end{array}$ & & 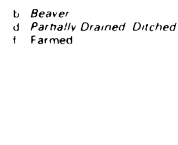 & 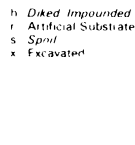 \\
\hline
\end{tabular}




\section{WETLANDS AND DEEPWATER HABITATS CLASSIFICATION}

SYSTEM

SUBSYSTEM

class

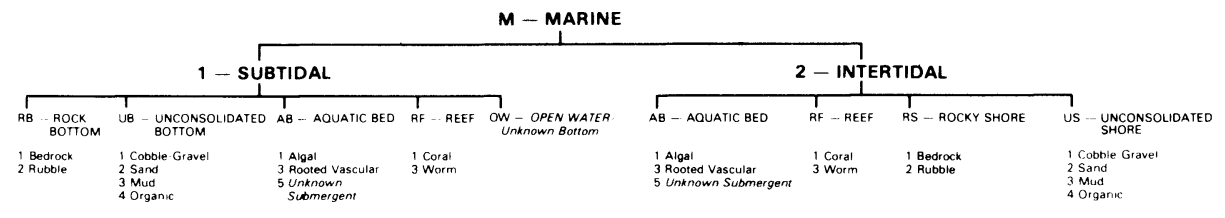

SYSTEM

SUBSYSTEM

Class

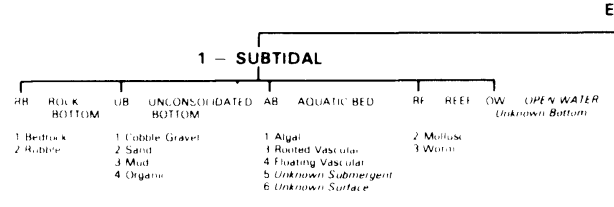

E- ESTUARINE

Subciso.:

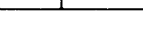

2-INTERTIDAL

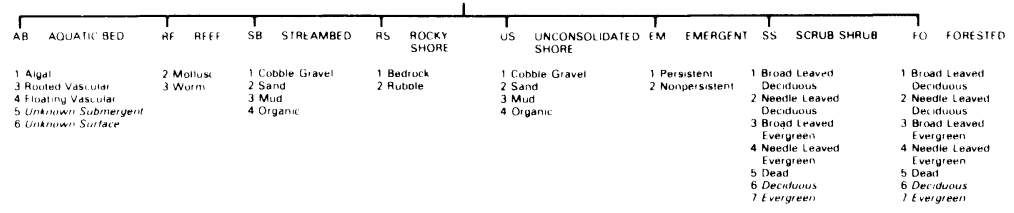

SYSTEM

SUBSYSTEM

CLASS

1 - TIDAL

R - RIVERINE

subclese:

I Bedrock

uB - UnCONSOLDATED
BOTOM
1 Cobble Gravel

2 - LOWER PERENNIAL 3 - UPPER PERENNIAL

4 - INTERMITTENT

5- UNKNOWN PERENNIAL

1 Cobble Gravel
2 Sand
3 Murd
4 Organic

1 Bedrock
2 Ruble
3 Cobole Gravel
4 Sande
5 Mud
6 Mud
6 Organic
7 Vgonic

1 Bedrock
1. Algat
2 Aquatic Moss
3 Rooted Vascular
2 Rubble
4 Floeting Vascula.

1 Cobble-Gravel
2 Sand
3 Mud
4 Organic
5 Vegetated

- EM - EMERGEN

OW-OPEN WATER/
Unknown Botrom 


\section{BACKGROUND}

The U.S. Fish and Wildlife Service is the lead Federal agency responsible for managing and conserving the Nation's fish and wildlife resources. Since wetlands provido significant habitats for many fish and wild life species (e.g., serving as waterfow breeding grounds, fish spawning and nursand hound, migras bind resting areas, Service is particularly concerned about the status of these habitats. Effective conservation of these important fish and wildlifo habitats requires knowledge of the variety of wetland types, their extent and distribution, and the adverse impacts of proposed projects on wetlands.

In 1954, the Service conducted its firs nationwide inventory of wetlands which focused on wetlands of major significanco to waterfowl. The results were published in a report entitled Wetlands of the United Wa 1950 s and the 1960s, the Servico continued to produce simila the Sorts of recent trends in specific wetland types in many states (o.g. coastal wetlands in New Jersey).

In the 1970s, there was widespread public concern over accelerating wetland losses. better understanding of wetland functions, and public recognition of values of we lands. New state laws were being passed to help slow the rate of wetland destruc-
tion. Increased regulation at the Federal level also took place through amendments to the Clean Water Act. More specific information on the Nation's wetlands was needed to help provide wise management of these valued resources. In 1974, the Inventory Project (NWI) to conduct a com prehensive inventory of the Nation's wetlands. This tremendous undertaking would produce an accounting of the Nation' wetlends through the preparation of maps and acreage reports.

\section{NWI OBJECTIVES}

Four major objectives of the NWI are: 1. To provide needed information to help
planners and decisionmakers achieve wet- land management and preservation objoctives:

2. To develop a wetlands inventory that is asily and economically maintained;

3. To develop a single, universally applicable systom to gather the basic informonomically possible;

4. To present information in a variety of forms (e.g., maps, digital databases, and (6) these inventory findings (6).

A wetlands inventory typically involves three steps: (1) identifying the location size, shape, and type of individual wet wetland maps, (2) compiling wotland acreage statistics from the maps for specific geographic areas, and (3) publishing the inventory findings. The NWI is producing a series of maps and reports on the wetlands inventory. To be most useful, the inventory must be periodically updated, especially in areas of significant change. In addition, the NWI is conducting studies that assess the current status and recent trends of the Nation's wetlands and updating NWI maps in selected areas. These and other

\section{NWI PRODUCTS}

A number of products have been or are being produced by the NWI, including: (1) wetland classification system report, (2) large-scale NWI maps, (3) state wetland reports, (4) national wetland status and
trends reports, (5) digital wetland map trends reports, (5) digital wetland map databases, (6) state or local wetland atlases. (7) specialized map products. and (8) regional wetland status and trends primery tion of the wetlands inventory, while the latter are more specialized products that increase the utility of NWI information or provide valuable data on wetland impacts.

Wotland Classification System Report

Prior to initiating the NWI mapping effort, the Service had to develop a standardized and universally acceptable system for dething and classifving wetlands. To do so toam of authors to prepare a first draft, and then sought the advise of the scientific community by initially holding a wetland classificetion conference at the University of Maryland, College Park (7), and later by sooking unprocedented peer review of draft versions of the classification system. Extensive field testing was also performod to assess the validity and practicality of the classification system in the field. The results of these efforts produced a technically sound wetland definition and classification oystom that ombodied the current state of our scientic knowledge on wotificetion system was published as Classification of Wetlands published as Classitets of the United States (1). It now serves as the national standard for watland identification and classification (4).

Large-scale NWI Mape

Large-scale wetland maps are the primary map product of the NWI. They are produced at a scale of $1: 24,000$ for most areas, except Alaska where 1:63,500 maps are being produced. These maps show the size, shape, type, and location of ats. The minimum mapping unit is typicelly a thout one acre in size; but may be maller than $1 / 10$ acre for special areas, such as the important waterfowl breeding grounds of the Prairie Pothole Region (Dakotas and western Minnesota). The maps are prepared through conventional aerial photo interpretation techniques using highaltitude aerial photography. Although the maps show the majority of wetlands in a given area (approximately 60 square miles for each 1:24,000 map), not all wetlands
are depicted due to inherent limitations of are depicted due to inherent limitations of quenty he tien process. Consequenty, do wetlands or to locate smaller wetlands and other wetlands that were difficult to photo interpret. The maps use alpha-numeric codes to represent various wetland types and deepwater habitats defined by Cowardin and others (1). The large-scale NWI maps are utilized by a wide variety of users such as engineers, environmental consultants, local conservation commis-
sions, foresters, hunters and fishermen and planning commissions as well as local, tory uses of the maps include project reviow, analysis of fish and wildlife habitat, watershed planning, special area management planning, land acquisition, oil spill contingency plans, baseline data on environmenmpact assessment wotland research study designs, wetland trends analysis, wetland permit review, wotland ovaluation, utility corridor siting, dovelopment plans, facility
oducation.

To date, large-scale NWI maps have been published for 70 percent of the coterminous twenty-two states have been finished: Arizona, Connecticut, Delaware, Florida Hawaii, Illinois, Indiana, Kentucky, Mary land, Massachusetts, New Hampshire, Now Jersey, New Mexico, Oklahoma, Oregon, Pennsylvania, Rhode Island, Tennessee, Vermont, Virginia, Washington, and West Virginia, plus the Pacific Island possessions, U.S. Virgin Islands, and Puerto Rico. By the end of 1998, NWI mapping should be completed for the lower 48 states. In the future, NWI maps will be updated in areas of significant wetland phy used was black and white film.

For information on how-to-order NWI mape. call 1-800-872-6277 (1-800-USA-MAPS): NWI map distribution center for your ares of interest.

\section{State Wetland Report}

To complete the wetlands inventory for a given state, the NWI must compile wetand acreage data from the NWI maps. wetland roport can be propered. To date this has been done on a limited basis, due to insufficient funding and the NWI's initial focus on producing wetland maps. Two types of state reports have been produced: (1) comprehensive state reports and (2) acreage summary reports. The former report presents the statistical results of the inventory along with much descriptive information on wetland hydrology, wet-
land plant communities, hydric soils, wet- and values, wetland trends, and wetland been completed - New Jersey (10), Delaware (11), Rhode Island (9), Connecticut (5), and Maryland (13). The comprehensive state wetland reports are among the service publi eports simply present tabular data on wetland acreages at the state and counties evels. These have been produced for several states, including Massachusetti, Pennsylvania, and Vermont.

National Wotland Status and Tronde Roports

The NWI assesses recent changes in the then's wetlands by conducting wetland status and trends studies on a regular
hasis. The first national wetland status and trends study was created to produce s statistically valid estimate of our Nation's
wetland resources and to document major adverse impacts to wetlands. This study Toverod the period mid-1950s to mid1970s. Technical and popular reports presenting these findings were published period mid-1970s to mid-1980s and pubished as a technical report (2). Thes land acreage by major wetland type and of orresponding losses during the study incrval. They are especially useful for detecting impacts to and rate of change in vetlands. These results can bo utilized by policy analysts to help develop sound policies for conserving wetlands. The Emergency Wetlands Resources Act of
1986 now mandates that the Service perform this wetland status and trends tudy at 10-year intervals.

Digital Wetland Map Databases

WWI maps may be most useful for plannin sets (e.g. soils and topography) in a graphic information system (GIS). Service is actively seeking funds to conert NWI map data into digital formats. To date, this effort has been chiefly funded by outside users, particularly individual states. bigital NWI map databases have been constructed for several states includin Delaware, Illinois, Maryland, New Jersey.
Virginia, and Washington. The digital data

formats available are DLG3 OPTIONAL, on writton to 9 or GRASS. Tho data Ca tridge, or $8 \mathrm{~mm}$ certridge in ASCll or UNIX TAR. Aveilablo rocording densitios for tho 9 track tape are 1600 and 6250 bpi. To order digital data, call 1-800-USA-MAPS please include the appropriate formatting information with your order).

\section{State or Local Wetland Atlases}

NWI has published atlases containin reductions of standard large-scale NW maps. Allases have been produced for

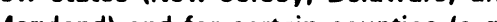
Kidder County, Norn Dan cous le.g. County, Californis. Although vory usefu Chey are not a standard NWI product, bu are custom products that are completely funded by outside sources. These atlases make it convenient to consult NWI infomation in the office and eliminate the need for obtaining and filing a complete set of Wimaps. The original large-scale maps, NWwever, romain the best products for the site-specific evaluation. Regarding the availability of NWI atlases in vour area, contact the appropriate Regional NWI Coo

Specialized Map Products

NWI has produced special wetland maps or specific areas, including the states of Florida and Maryland. In addition, a gen published.

Regional Wetland Status and Trends Studie

The national wetland status and trends study is designed to produce national es-

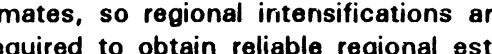
mates. Such intensifications havo been done for five Mid-Atlantic states and th Chesapeake Bay watershed (14). In addition, local wetland trends studies are being performed for selected counties or Wher areas. For information on regiona wetland trends, contact the appropriat 
FOR SPECIFIC INFORMATION ABOUT THE NATIONAL WETLANDS INVENTORY IN YOUR AREA, CONTACT THE APPROPRIATE REGIONAL NWI COORDINATOR LISTED BELOW.

Cowardin, L.M., V. Carter, F.D. Golet and E.T. LaRoe. 1979. Classification of Wo and Doopwater Habitats of the United States. U.S. Fish and Wild life Sorvice.

W. T.E. and CE Johneon. 1991 Status and Trende of Wotlands in the Conterminous . Mid-1970s to Mid-1980s. U.S. Fish and Wildifie Service, Washington, DC. $28 \mathrm{pp}$.

3. Frayer, W.E., T.J. Monahan, D.C. Bowden, and P.A. Graybill. 1983. Status and Tronds of Wetlands and Deopwater Habitats in the Contorminous United States, 1950 s to 1970 .
Dopartment of Forest and Wood Sciences, Colorado Stato University, Ft. Collins. 32 pp.

4. Mader, S.F. 1991. Forested Wetlands Classification and Mapping: A Literature Review. National of the Paper Indust
Technical Bulletin No. 606.

5. Metzler, K.J., and R.W. Tiner. 1991. Wetlands of Connecticut. State Geological and Natural History Survoy of Connecticut, Department of Environmental Protection, Hartford. Report of Investigations No. 13. $114 \mathrm{pp}$. plus color plates.

6. Montanari, J.H., and B.O. Wilen. 1978. Techniques developed and presently being used to conduct the National Wetland Inventory Project. In: J.H. Montanari and J.A. Kusler
leditors). Proceedings of the National Wetland Protection Symposium (Reston, VA; June 6-8, 1977). pp. 205-212.

7. Sather, J.H. (editor). 1975. Proceedings of the National Wetland Classification and and Wildlife Service, Washington, DC. 110 pp.

B. Shaw, S.P. and C.G. Fredine. 1956. Wetlands of the United States: Their Extent and Their Value to Watertow
Circular 39.67 pp.

Tiner, R.W. 1989. Wetlands of Rhode Island. U.S. Fish and Widlife Service, Newton Corner, MA. National Wotlands Invontory report. 71 pp.

10. Tiner, R.W... Jr. 1985a. Wotlands of New Jersey. U.S. Fish and Wildlifo Service, Nowton Comer, MA. National Wetlands Inventory report. 117 pp.

11. Tiner, R.W., Jr. 1985b. Wetlands of Delaware. U.S. Fish and Wildlife Service, National Wotlands inventory, Nowton Comer. MA and Delaware Department of Natural Resources Inventory report. $77 \mathrm{pp}$.

2. Tiner, R.W.. Jr. 1984. Wetlands of the United States: Current Status and Recent Trende. U.S. Fish and Wildlife Service, National Wetlinads Inventory, Washington, DC. 59 pp.

13. Tiner, R.W., and D.G. Burke. 1992 Wetlands of Maryland. Maryland Department of Natural Resources. Water Resources Administration, Annapolis and U.S. Fish and Wildlife SorWotlands Inventory report.

14. Tiner, R.W., Jr. and J.T. Finn. 1986. Status and Recent Trends of Wotlands in Five Mid-Atlantic States: Dolaware, Maryland, Pennsylvania, Virginia, and West Virginia. U.S. Fish and Wildlfie Service, Newton Comer, MA, and U.S. Environmental Protection Agency, region III, Philadelphia, Pa. Cooperative publication. $40 \mathrm{pp}$.
Region Geographic Area NWI Coordinator

U.S. Fish and Wildfie Service Eastside Federal Complex Phone: 503/231-6154

2 Arizona, New Mexico, Oklamoma, Texas

U.S. Fish and Wildlife Service 500 Gold Avenue, SW, Rm 4012 Phone: 505/766-2914

U.S. Fish and Wildlife Service Federal Building, Fort Snelling Phone: 612/724-3417 Michigan, Minnesota,

U.S. Fish and Wildlife Service R.B. Russel Federal Building 75 Spring St., S.W.Suite 1276 Atlanta, Georgia 30303 Georgia, Kentucky, Lou Mississippi, North Carolina, Puerto Rico, South Carolina, Tennessee, Virgin Islands

5 Connecticut, Delaware, Maine, Meyland, Massachusetts, New Yor, Pew Jersey, Virginia, West Virginia

6 Colorado, Kansas, Montana, Nebraska, North Dakota, South Dakota, Utah, Wyoming

U.S. Fish and Wildlife Service P.O. Box 25486

Denver Federal Center

Denver, Colorado 8022

Phone: 303/236-2985

$7 \quad$ Alaske

U.S. Fish and Wildlife Service

U.S. Fish and Wildlife Service Ono Gatoway Cont, Sulce 513 Phone: 617/965-5100 ext. 379 Portland, Oregon 97232-4181 Albuquerque, New Mexico 87103 Rhode Island, Vermont,
THE NATIONAL WETLANDS INVENTORY PROJECT 1011 East Tudor Road

Phone: 907/786-3403

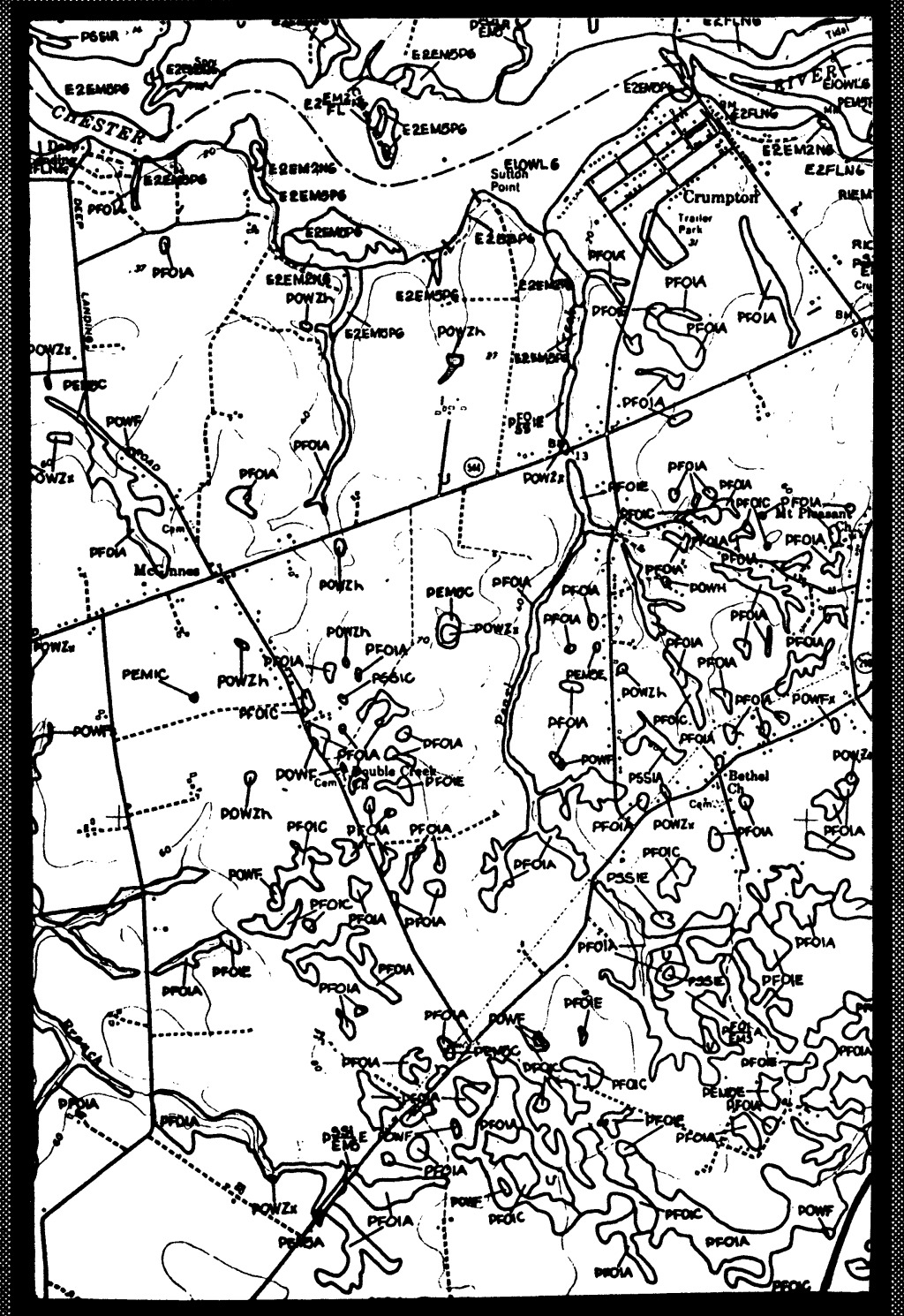

U.S. Fish and Wildlife Service 


\section{WETLANDS AND DEEPWATER HABITATS CLASSIFICATION}

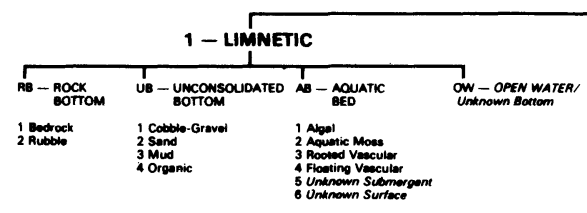

L - LACUSTRINE

suretros

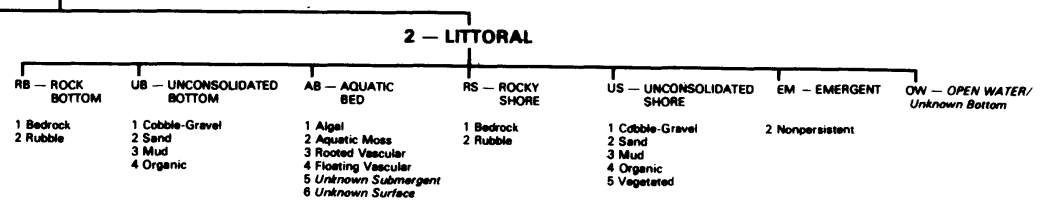

SYSTEM

cuase

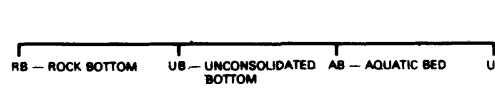

P-PALUSTRINe

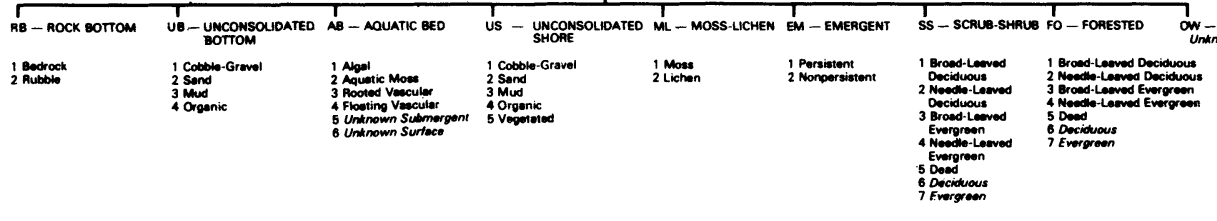

MODIFIERS

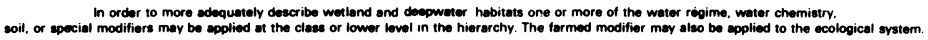
WATEA REGIME

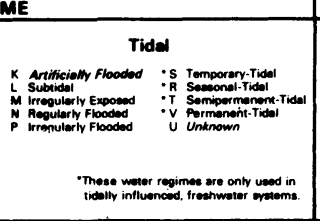

WATER CHEMISTRY

Coastal Malinity Inland Salinity PH Modifiers for

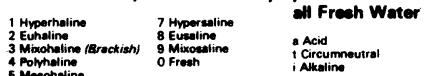

5 Mosoheline
6 Olinghatine
OFresth

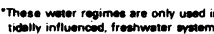

SPECIAL MODIFIERS

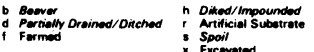




\section{WETLANDS AND DEEPWATER HABITATS CLASSIFICATION} SYSTEM

SUBSYSTEM

cuss

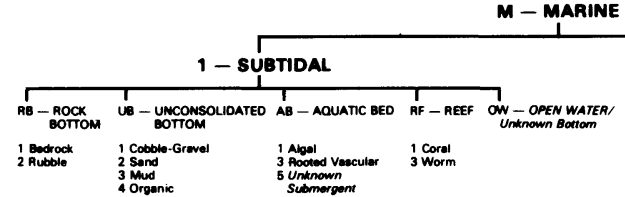

\begin{tabular}{|c|c|c|c|}
\hline \multicolumn{3}{|c|}{2 - INTERTIDAL } & \\
\hline 8- AOVATIC & RF - REEF & PS - ROCKY SHOPE & 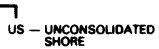 \\
\hline 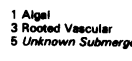 & $\begin{array}{l}\text { icoral } \\
3 \text { Worm }\end{array}$ & 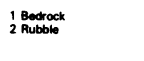 & 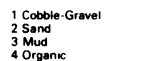 \\
\hline
\end{tabular}

SYSTEM

SUBSYSTEM

cass

\begin{tabular}{|c|c|c|c|}
\hline \multicolumn{4}{|c|}{1 - sugridoal } \\
\hline $\begin{array}{l}\text { RB- Rock } \\
\text { BOCrom }\end{array}$ & $\begin{array}{l}\text { UE - UMCONSOLIDATEO } \\
\text { BorTOM }\end{array}$ & AB - AQUATIC BED & 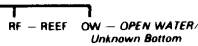 \\
\hline $\begin{array}{l}1 \text { actrock } \\
\text { a Rublite }\end{array}$ & 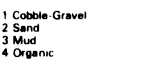 & 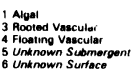 & 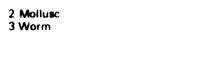 \\
\hline
\end{tabular}

E- ESTUARINE

suscom

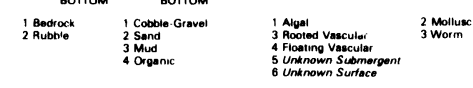

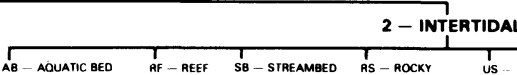

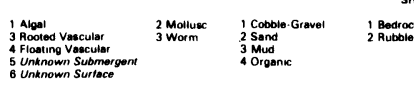

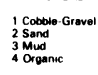

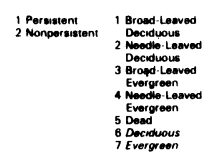

R - RIVERINE

\section{SYSTEM}

SUBSYSTEM

cuass

\begin{tabular}{|c|c|c|c|c|}
\hline & \multicolumn{3}{|c|}{ R - RIVERINE } \\
\hline 1 - TIOAL & & 2 - LOWER PER & INIAL & PPER PERENNIAL \\
\hline 8 - Rock & $\begin{array}{l}\text { UB - UNCCONSOUDATED } \\
\text { BOTrMom }\end{array}$ & SB - STREMMBED & AB - AOUATC BED & RS - ROCKY SHOAFE \\
\hline 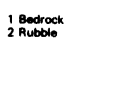 & 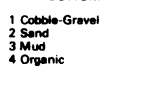 & 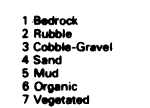 & 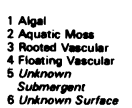 & 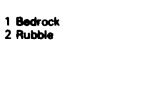 \\
\hline
\end{tabular}

4 - INTERMITTENT 5 - UNKNOWN PERENNIAL

sucosers

$$
\text { в8 - воск }
$$

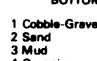

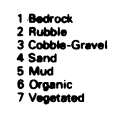

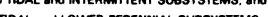

Classification of Wettands and Deepwater Habitats of the United States Cowardin ET. AL. 1979 as modified for National Wetland Inventory Mapping Conventio 

As the Nation's principal conservation agency, the Department of the Interior has responsibility for most of our nationally owned public lands and natural resources. This includes fostering the wisest use of our land and water resources, protecting our fish and wildlife, preserving the environmental and cultural values of our national parks and historical places, and providing for the enjoyment of life through outdoor recreation. The Department assesses our energy and mineral resources and works to assure that their development is in the best interests of all our people. The Department also has a major responsibility for American Indian reservation communities and for people who live in island territories under U.S. administration.
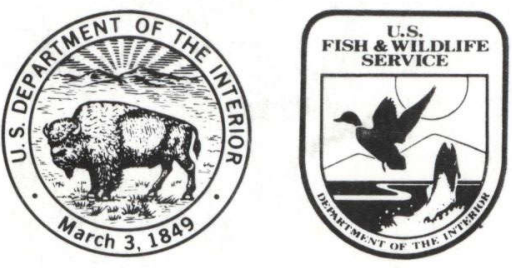

Fish and Wildlife Service U.S. Department of the Interior Washington, D.C. 20240 